
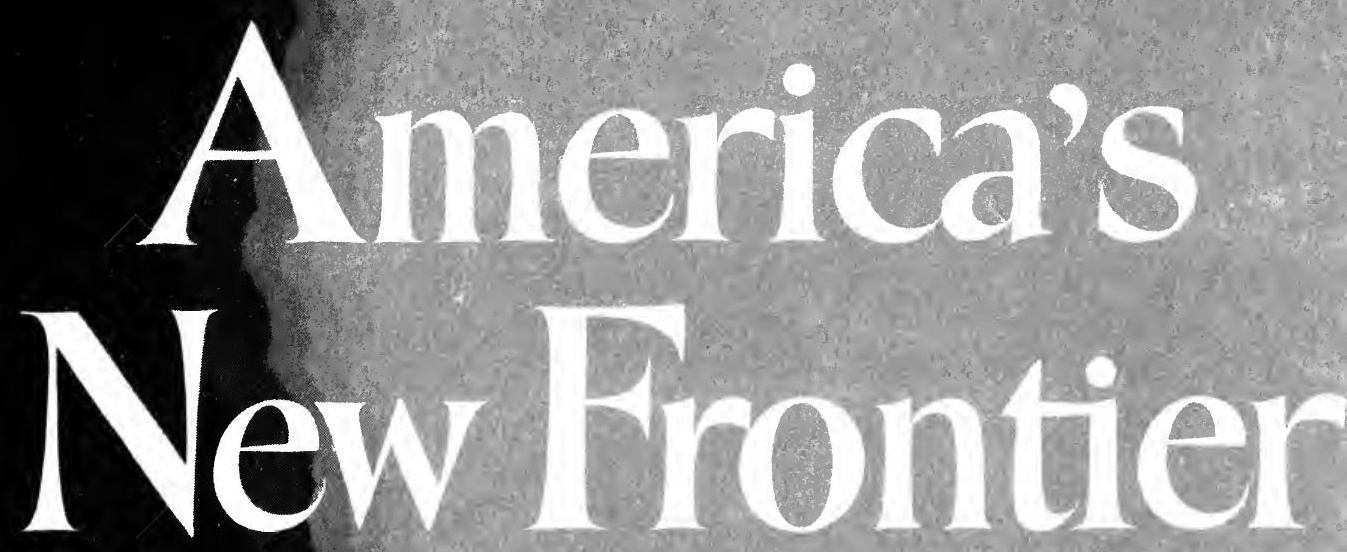

\title{
THE MOUNTAIN WEST
}

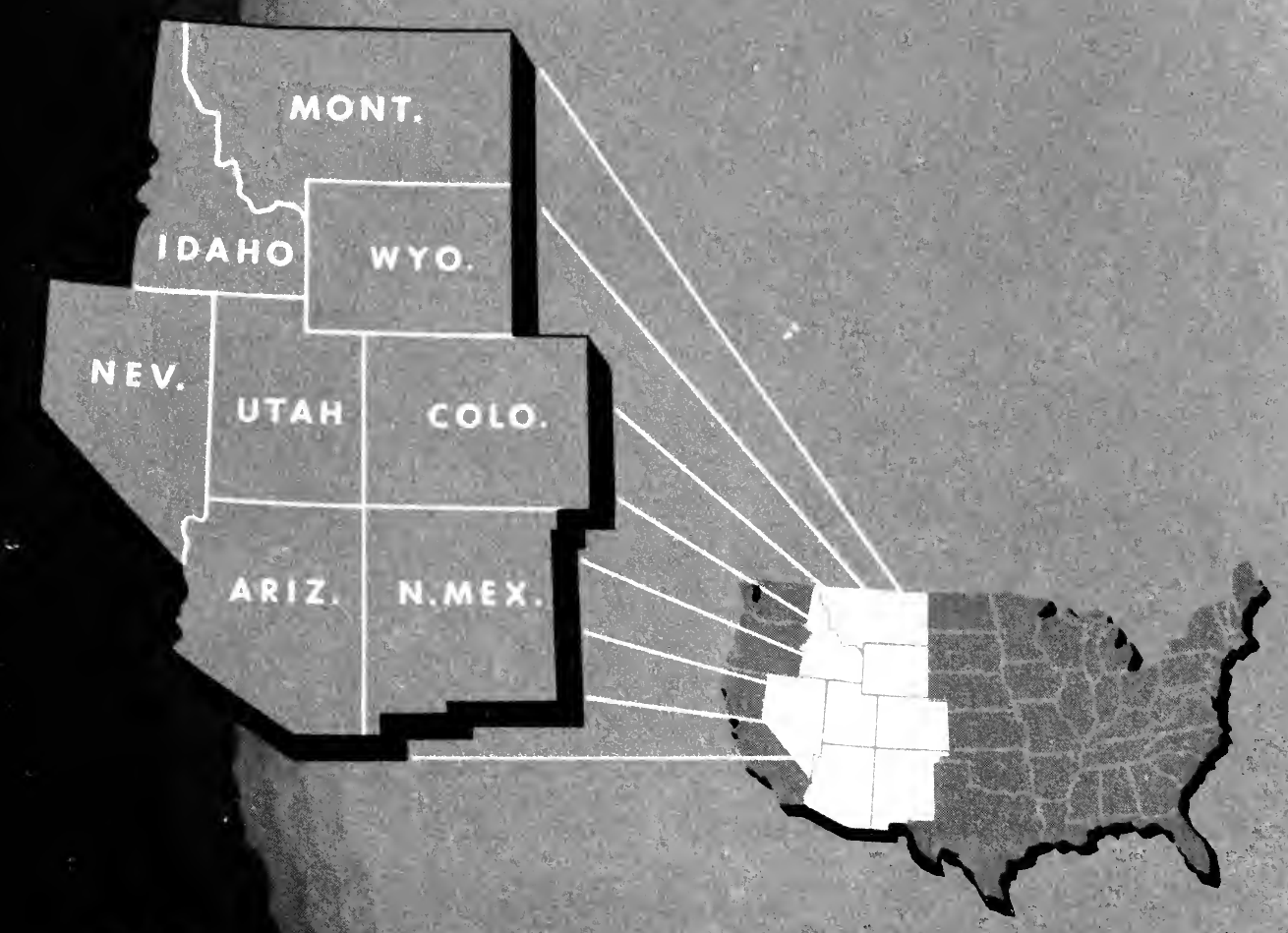

BY 'ORRIS E. GARNSEY

FRED A. KNOPF, PUBLISHER, N.Y. 


\section{America's New Frontier}

\section{THE MOUNTAIN WEST}

The eight STATES of the Rocky Mountain West are seething with vast and dramatic changes of a kind that has stirred the imaginations of men for centuries. This book paints a striking picture of these changes in their physical, economic, and political aspects. The old frontier scarcely paused at the Mountain West. Now it is once again at the Rockies, but it is a frontier of new industries, of capital investment, of land reclamation and conservation, of spectacular new dams and lakes, and of the new philosophy of regional development. Garnsey tells a story of silver, sheep, and sugar; of shale oil and atomic energy; of water resources and power development. $\mathrm{He}$ offers a pioneer study of regional finances. $\mathrm{He}$ also faces the many problems of the region, and his answers and interpretations go to make a stimulating, lively, and engrossing book. 
From the collection of the

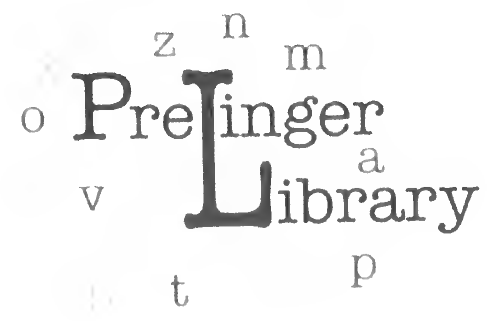

San Francisco, California

2006 
. 
America's New Frontier 


\title{
America's New Frontier
}

\author{
T H E
}

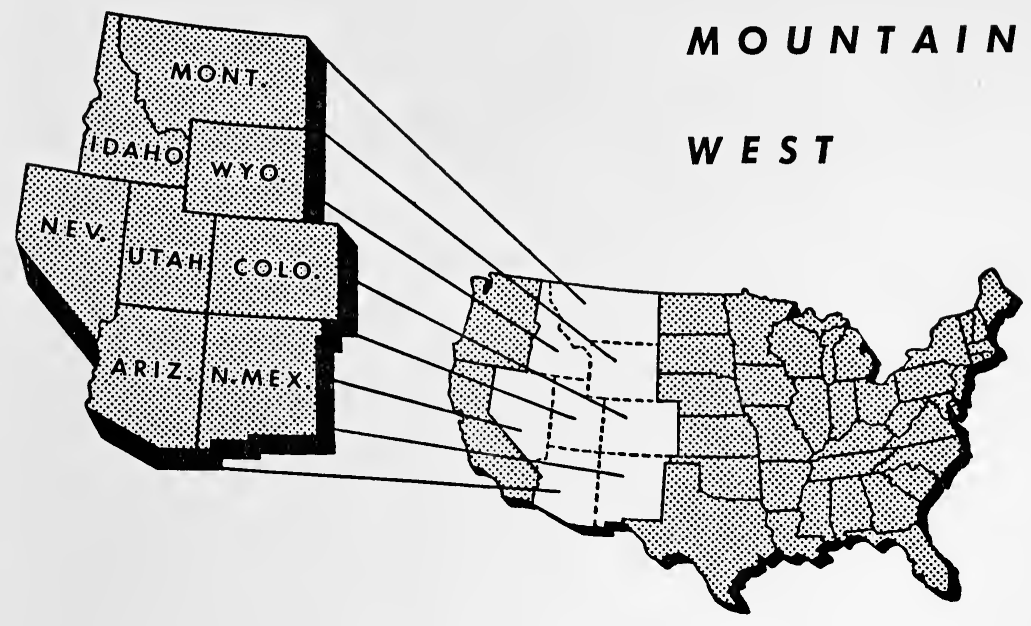

by Morris E. Garnsey

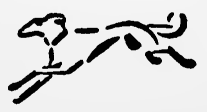

NEW YORK

Alfred A. Knopf

1950 
This is a Borzoi Book, published by Alfred A. Knopf, Inc.

Copyright 1950 by Alfred A. Knopf, Inc. All rights reserved. No part of this book may be reproduced in any form without permission in writing from the publisher, except by a reviewer who may quote brief passages and reproduce not more than three maps and/or charts in a review to be printed in a magazine or newspaper. Published simultaneously in Canada by McClelland \& Stewart Limited. Manufactured in the United States of America.

First Edition 
To My Father:

whose own westward migration

and subsequent career exemplify the values of personal freedom and independence. 
"The progressive state is in reality the cheerful and the hearty state to all the different orders of the society. The stationary is dull; the declining melancholy."
A D A M S M I T H :
An Inquiry into the Nature and Causes of
the Wealth of Nations. I776. BOOK I, CHAPTER 8. 
Preface:

Why should anyone write a book about the Mountain West-a sparsely populated region which contains only three per cent of our population, and whose inhabitants buy only a scant two per cent of the books sold in the United States? What compelling reasons can be advanced for further disturbing the always precarious balance between the supply and demand for books with a volume so limited in appeal? Should the prospective reader pick up this book with such sceptical questions in mind let me assure him at once that this book is meant for him, as well as for those who have some special interest in the American West. The significant events which are shaping up today in the Mountain West will have definite and important effects on the future prosperity and economic stability of the American economy as a whole. The economic policies for the West which are being debated even now by western legislatures and by the Congress are likely to affect the personal prosperity of practically every single individual in the country.

Nevertheless, there exists no comprehensive survey of 
the nature of the economy of the Mountain West and its relation to the national economy. The Mountain West is not fully understood nor appreciated either within the region or in the country at large. Consequently, the first purpose of this book is to examine the economy of the Mountain West as it now exists and to anticipate, in some degree, its future development.

The second purpose of the book is to analyze and assess the current policies of government and industry which are determining the present and future economic structure of the region. For the facts show clearly that the Mountain West has reached a crucial stage in its development. The American people are now making decisions which will determine whether the Mountain West is to become a backwoods or a frontier in American life-a region of prosperous inhabitants contributing valuable resources to the national economy for many decades to come, or an underdeveloped and neglected region whose resources have been irreparably exploited and destroyed. These decisions should not be taken carelessly. There should be a careful examination of the alternatives and a close scrutiny of their various implications. We need to know what we are doing before it is too late.

Unfortunately, not all of the policies now in effect in the West have been soundly conceived. In some cases even local policies have been formulated without adequate information about the region. In other cases national policies have been decided upon without reference to the regional implications of the actions taken. We need, therefore, not only more comprehensive information about the Mountain West but also a reformulation of policy for western development. My own suggestions for a program for the conservation and development of western resources form a part of the present study, and I hope that they will be given consideration by our policy-makers in the years ahead. 
My belief in the importance of sound policy for the West may be influenced by my nearness to and sympathy with western problems, but it also has a more objective basis. I regard this book as an experiment in the regional approach to economic analysis and policy. The spatial, or place, aspects of economic problems frequently are not recognized in the literature of Economics. Too little attention is paid to the fact that our national economy is composed of a number of distinct regions which have peculiar characteristics of their own. It should be evident, for example, that the decisions of a large-scale corporate enterprise concerning such things as the location and operation of its plants, its method of quoting prices, and its sales and advertising policy have regional repercussions. Nevertheless, economists have ignored the regional phases of the problem of economic concentration almost entirely, while devoting most of their attention to the functional aspects of the problem-utilization of resources, income distribution, and so forth. In the same way legislative or administrative policy decisions of the federal government often are determined on purely functional grounds without regard for the different repercussions of a given policy in the various regions of the country.

The failure to anticipate the regional impact of national policies gives rise to sectional discord and encourages the self-seeking of special-interest blocs; and it is precisely this danger which regional policy hopes to avoid. Sectionalism is a pathological manifestation of the regional diversity of our country, and the way to combat the disease is to bring to the study of regional problems the methods and objectivity of the scientific approach. I see no reason why public opinion should not be mobilized on a regional basis to influence national policy in constructive ways, as long as such opinion is based on sound research into regional problems. If economists will provide a basis of research into the regional as- 
pects of economic problems, the facts about regional potentialities and inter-regional relationships can be established; then public opinion can be mobilized on the basis of fact instead of prejudice. The end result will be the achievement of a better regional balance in the American economy and, consequently, a more stable and more efficient economic system.

The regional approach to economic analysis can be useful in most areas of economic policy, but its greatest value is likely to be found in the field of resources development. After all, a region is formed to a very large extent around its resources, and the material well-being of its people depends upon the effective utilization of the resources at their disposal. In the so-called backward or underdeveloped regions of the United States resources are not lacking. The barriers to their full development are found in economic and social institutions of various kinds. It would seem wise to attack these institutional barriers indirectly by disclosing them as obstacles to a program of resources development. In other words, the place to begin is with an analysis of the region's resources and an evaluation of their potentialities. From this a program for better utilization will evolve most readily. Such a program can point the direction for effective resources use in specific terms, outline the steps to be taken and reveal the obstacles to be overcome if progress is to be achieved.

Regional programs of the kind envisioned here are already in existence. The Tennessee Valley and the Pacific Northwest are probably the best examples of programs in action. There are still others in the South which are welladvanced in the planning stage. There is as yet no over-all program in the Mountain West, but there are signs of a developing regional consciousness in the West. It is my hope that this book will make at least some contribution toward the beginnings of a significant regional program in the Moun- 
tain West. I hope, also, that it will stimulate further research in the economic and social problems of the West. More data are needed on income flows, investment, and gross regional product. The present volume is merely exploratory in these directions. Studies of costs and benefits of developmental projects should be carried further and disseminated much more widely than at present. Other desirable research projects of a regional nature will occur readily to the reader.

I am aware that a good deal of what I have said is controversial and expresses a point of view which others may not share. Consequently, I wish to make it clear that I am solely responsible for the views expressed, even though my debt to many persons with whom I have consulted is very great indeed. Much of the work on the regional balance of payments is that of Professor J. Howard Craven of the Department of Economics of the University of Wyoming. The income and productivity studies in Chapters 10 and 11 summarize the original research of Mr. William H. Miernyk of the Department of Economics of the University of Colorado and some earlier work by Mr. Harry McAllister of the Department of Economics of Washington State College. The data on the sugar beet industry were compiled and analyzed by Mr. Wilbur. T. Billington, now Instructor in Economics at the University of Minnesota. I am indebted to Dr. C. Victor Dorrell for his invaluable assistance in the collection of data and drafting of the maps and charts.

I have had the privilege of discussing particular points in the manuscript with officials of numerous state agencies and federal bureaus, both in the field and in Washington. In every case I have found a high degree of interest and cooperativeness on the part of both the professional and the administrative officials whom I have consulted. The suggestions, criticisms, and unpublished data which I have received from governmental sources have been invaluable to me. 
I wish to thank the staffs of the Norlin Library and the Bureau of State and Community Service, both of the University of Colorado, for their unfailing generosity in searching for references and providing statistical and secretarial assistance to me. I am particularly indebted to Miss Ellen Jackson, Librarian of the Documents Division of the Norlin Library. I am especially grateful to Mr. Paul F. Gerhard, Research Assistant, for his expert attention to countless details of research and for the compilation and checking of the bibliography.

Finally, this study could not have been initiated or completed without the periodic leaves of absence from teaching which the University of Colorado provides for its faculty. On one such leave I was able to visit the Institute for Research in Social Science at the University of North Carolina and discuss my projected study with the members of its staff, much to my advantage. In 1948, a similar period of leave permitted me to devote full time to research under the grant of a fellowship from the John Simon Guggenheim Memorial Foundation. Two subsequent grants from the Lucius $\mathrm{N}$. Littauer Foundation made possible the completion of the manuscript. A grant from the Graduate Council on Research and Creative Work of the University of Colorado facilitated the final revision and checking of the manuscript. I hope that the University and the foundations will feel that the present contribution to our knowledge and understanding of the Mountain West as a regional division of the American commonwealth is a partial recompense for the debt which I owe to their generosity. 
Contents:

Part One: The Place of the Mountain West in the American Economy

I Introduction

II The Rise of the Modern West

$A$ definition of the contemporary West-Economic and political significance of the westward movement.

III The Decline of the Mountain West

"Leap-frogging” to California-The effects of the war-The question of water.

IV America's Stake in the West

America's economic goals: 1950-1960-Productivity of Western agriculture-Mineral resources of the West-Hydroelectric power.

\section{Part Two: The Resources Base}

V Regional Characteristics of the Mountain West

Physical characteristics of the Mountain West 
-Economic characteristics of the regionCultural characteristics of the Mountain West -The habit of exploitation.

VI A Brief Inventory of Resources-Utilized and Unutilized

Minerals-Forests-Recreation-Agricultural land-Water and power-Atomic energy in the Mountain West.

\section{Part Three: The Economic Base}

VII Population

Density and geographic distribution of the population-Race, age, and sex-Economic problems of minorities in the Mountain West -Migration: past, present, and future.

VIII The Labor Force and Employment

The labor force in 1950-Possibilities for employment by 1950 .

IX Production in the Mountain West

The regional production pattern-The dispersion of productive activities within the region -Determinants of underdevelopment of manufacturing-Post-war trends in manufacturing.

\section{Part Four: Relative Economic Position of the Region}

\section{$\mathrm{X}$ Income}

Relative income position of the Mountain West-Sources of income-Variations in per capita income among states of the Mountain 
West-The stability of incomes in the Mountain West.

XI Productivity

Occupational patterns of the Mountain WestProductivity in agriculture and manufacturing -Output per worker in agriculture-Productivity in manufacturing-Summary.

XII A "Balance of Payments" for the Mountain West

Importance of regional income flows-Exports of the Mountain West-Imports of the Mountain West-Financial transactions: Role of the Federal Government-Striking a balance in inter-regional trade.

XIII Institutional Barriers to Regional Development ${ }_{168}$ Freight rates do matter-The ideal freight rate structure-Regional impact of basing point pricing.

\section{Part Five: Politics and Economics}

XIV Silver, Sheep

Silver-Sheep-Sheep, cattle, and conservation.

XV And Sugar

Criticisms of the beet sugar industry-The technological revolution-Toward a lower price for sugar?

XVI The Betrayal of the Western Liberal Tradition 230 Liberal revolts in the West from Jefferson to Bryan-The eclipse of Western liberalism- 
Toward the rebirth of the Western liberal movement.

XVII Regional Rivalries and Regional Alliances

Struggle over water-The water issue and the $M V A-F r e i g h t$ rates in politics-Rise of regionalism in the Mountain West.

\section{Part Six: America's New Frontier}

XVIII The West-A New Frontier

New frontiers in resources development-The conservation frontier.

XIX The New Frontier of American Liberalism

The role of government in economic lifeWestern liberalism and social action.

XX A Program for Action

A twelve-point declaration of liberal policyWestern policy and the nation.

Appendix: Statistical Tables

Bibliography

Index 


\section{Tables:}

1 Population in the West 1850-1949 (in Millions)

2 National Mineral Supply-Production and Reserves Accounted for by the Mountain West

3 Estimated Labor Force, 1940 and 1945, and Projections, I950, Under Three Assumptions as to Volume of Interstate Migration

4 Percentage distribution of employed workers in major industry groups-United States and Mountain West-and deviations of the Mountain West from the United States Industrial Pattern-1940

5 Deviations of States of the Mountain West from the United States Industrial Pattern-1940

6 Trends in Regional Share of National Income Payments

7 Major Industrial Sources of Income Payments in the Mountain States: Selected Components as a Per cent of Total Income, 1940 and 1946

8 Percentage Distribution to the Mountain States of Total U.S. Income Payments from Private and Governmental Sources, 1929-1940-46 
9 Occupational Patterns in the Mountain West and U. S.: $1880-1940$

10 Output per head in agriculture, 1878-1939 (in constant dollars)

11 Output per head in manufacturing (in constant dollars)

12 Index of Slaughter of Cattle and Calves Under Federal Inspection at Selected Stations, 1940-1948

13 Slaughter of Cattle and Calves in Denver, Colorado as a Percentage of Total United States Slaughter $1940-48$

14 Impact of the War on the Mountain West-in terms of direct changes in regional economic activity and relative changes in the region's share of total national activity

15 Comparison of value added by the agricultural production process with value added by manufacture per worker, United States and geographic divisions, 1939

16 Sex and Race by States (1940)

17 Population of the Mountain West by Certain Age Groups, by Sex, 1940

18 Number and Per cent of White Population of the Mountain West reporting Spanish as the Mother Tongue, by States, 1940

19 Population of the Mountain West by Race, Nativity, and Sex, I940

20 Estimated Annual Average Net Migration, for the Mountain West and Component States

21 Percentage of Total Labor Force Employed in Mining and Manufacturing, I880 to 1940 


\section{Maps:}

1 Relief Map of the United States, showing boundaries of the Mountain West

2 Rainfall Map of the United States (20-inch rainfall line in heavy black)

3 Agricultural Regions of the United States 45

4 Principal Crops of the Mountain West 46

5 Forests and Approximate Irrigated Areas of the Mountain West

6 Irrigation and Power in the Mountain West $5^{1}$

7 Principal Minerals Produced in the Mountain West $5^{2}$

8 Geographic Distribution of the Population of the Mountain West, 1940 


\section{Charts:}

1 Growth of Population in the West 1850-1949

2 Net Gain of Population through Inter-divisional Movement; Mountain and Pacific (1870-1940)

3 Trends in Regional Share of National Income Payments

4 Changes in Regional Per Capita Incomes: 1940-46

5 Occupational Patterns in the Mountain West and U. S.: $1880-1940$ 


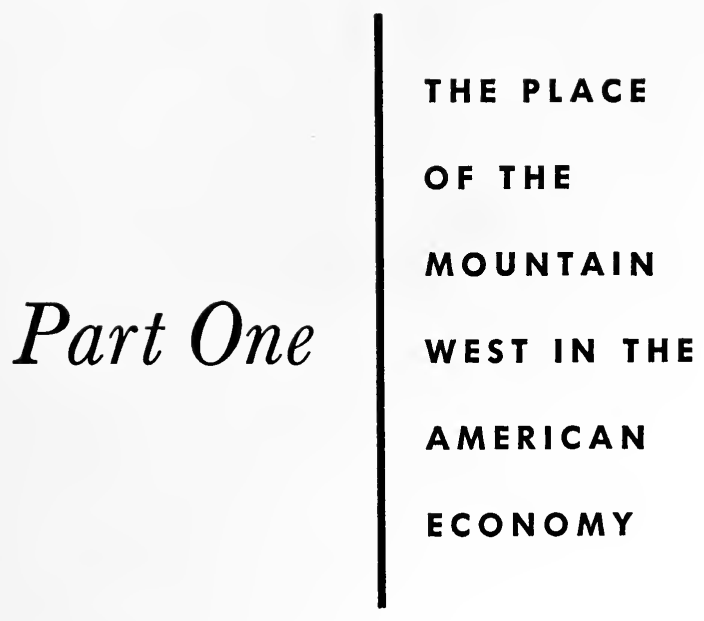





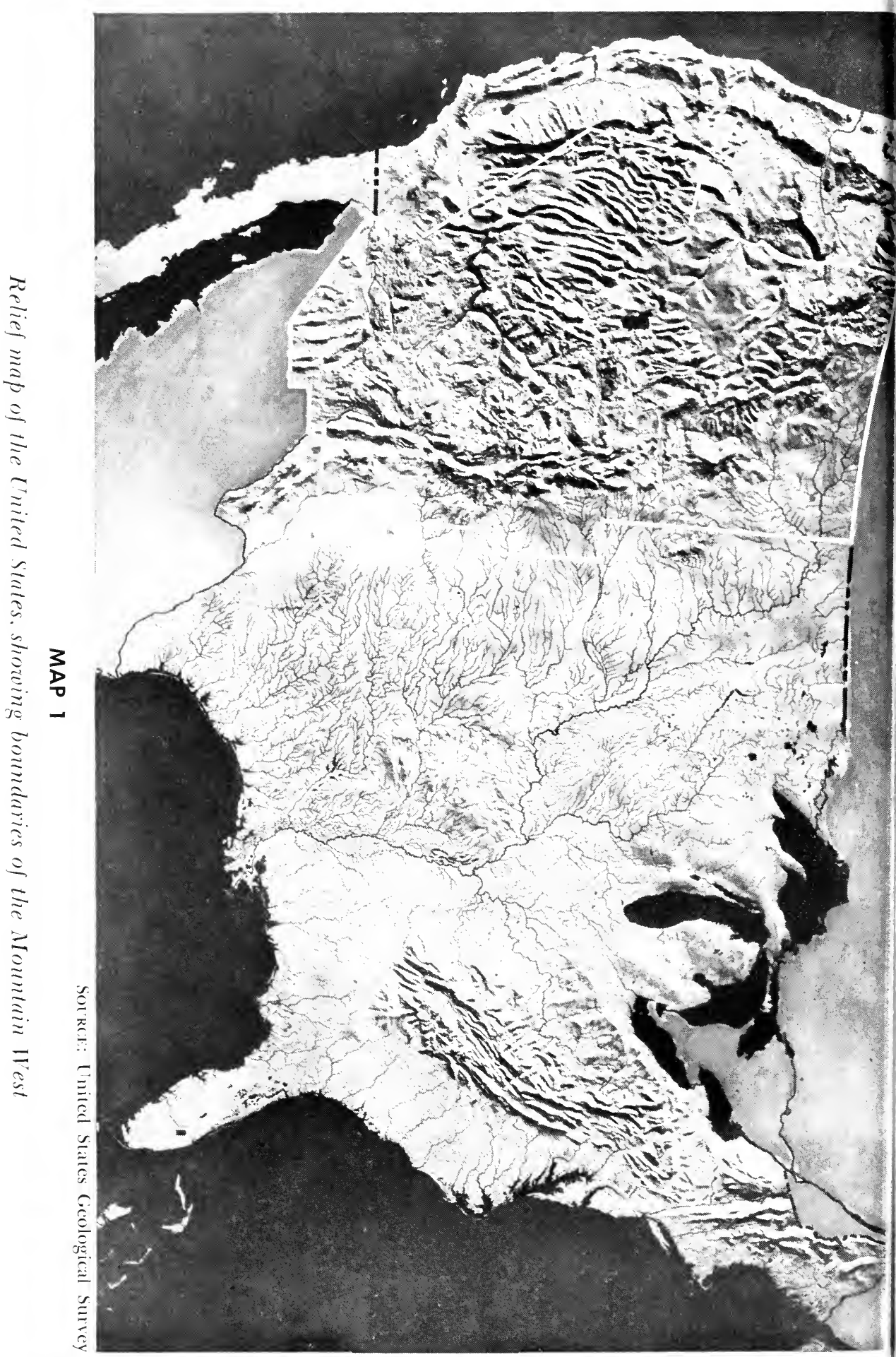


Chapter 1. Introduction

Not so long ago the Mountain West was America's last frontier. Today it promises to become once more a frontier in our national life-America's new frontier.

In the $185^{\circ}$ 's Oregon and California were the focus of the westward movement and the Mountain West was skipped over in the westward trek. Later, in the 70's and 80's, the pioneers turned back to the Mountain West and rapidly brought the region under the bonds of fence and plow. Thus, the last gap between the Atlantic and the Pacific was closed, and a unified nation was created.

Today the westward movement is again leap-frogging over the Mountain West to the Pacific. But eventually the nation will have need for the vast resources of minerals, forests, and lands which now lie idle in the West. Already the supplies of petroleum and phosphates in other regions are becoming inadequate, and Western reserves are being drawn upon at an increasing rate. As these resources are, at last, brought to full development, the Mountain West may again become an economic frontier, providing jobs and opportunities for capital investment for a significant number of the 
American people. When this day comes the present outflow of population will be reversed, and a capital investment of $4^{o}$ to $5^{o}$ billion dollars in twenty or twenty-five years is not unlikely.

Nevertheless, the present relative inactivity in the economic expansion of the Mountain West is no accident. Some areas, such as the Pacific Coast, have natural advantages not possessed by the Mountain West; others, such as the Gulf Southwest, have acquired reserves of capital and political acumen which have given them an impetus not felt in the Intermountain area. However, it is in the Mountain West itself that the strongest obstacles to its own expansion exist. Within the borders of the Mountain States are to be found numerous institutional and political barriers which have hampered the region's development.

Such factors as freight rates, the pricing policies of corporate enterprise, and the conservatism of our own leaders have discouraged Western expansion. More important, there has been lacking, at both the regional and national levels, a vigorous determination to push the utilization of the region's scarce water resources to their maximum development in irrigated agriculture and hydroelectric power for industrialization. This lack of aggressiveness in economic expansion can be traced in large part to the influence of the special-interest blocs in the West. Allied with Eastern industrialism, these blocs have betrayed the Western liberal tradition by placing their own interest above those of the region and nation and by defending the status quo in order to protect their own position with the greatest effectiveness.

It is this activity of the blocs which reminds us most sharply that historically the westward movement is not merely an economic phenomenon. Its influence has been political and social as well as economic and its repercussions more far-reaching than a periodic stimulus to economic ex- 
pansion and prosperity. Present conditions in the West remind us also that the West of today is no longer an uninhabited wasteland with gold and silver in every creek and hill. The untapped resources of today's West cannot be plundered with the abandon of the nineteenth-century prospector and cattleman or the selfishness of the twentieth-century exploiter. The rational development of the region's resources will require the relinquishment of a naive belief in a bountiful and limitless Nature whose riches justify ruthless exploitation. We must realize that our resources are limited and exhaustible and that they must be used in ways which will conserve them for future use and growth. In some respects this realization seems far away when we witness the attacks of special-interests on our public lands and stand by helplessly while millions of acres of the Dust Bowl are once more broken by the plow. But fortunately there are many people in the West who understand that resources development and conservation go hand-in-hand. Consequently, the Mountain West promises to become a new frontier in the development of techniques and practices for the conservation and use of scarce natural resources.

But as such techniques are devised it becomes increasingly evident to the conservation-minded that the forms of social organization must be revised to fit the new environment. The modern technology of land, water, and forest utilization requires large-scale, long-range methods. Under these circumstances it is logical that the role of government in economic affairs should expand beyond the narrow confines to which it was held by nineteenth-century philosophy. The present-day conservationist does not look upon his government as a policeman or an umpire, but as a partner in the democratic evolution of co-operative and mutually beneficial programs for the protection and development of the resources of the region and nation. 
Many Westerners who are concerned with the future of the region have come to accept this newer attitude toward government, but in order to secure the understanding and support of the majority of the American people it will be necessary to dislodge the political power of the special-interest blocs and to create a new kind of liberal spirit in American politics. Will the West again become, as so often in the past, the birthplace of a new liberal movement in the United States? Will it once more carry the fight against restrictive practices and the exploitation of our scarce natural resources? Will it reaffirm the democratic principle that the riches of Nature are the heritage of all the American people? Here again are signs which point toward such a possibility.

The Mountain West has reached a significant point in its economic development - the crest of a divide. Since the first settlement the progress of the region has been upwardfirst rapidly and then more slowly. Now it appears that relative stability or decline lies ahead unless the West deliberately sets out to create new policies and programs for future growth. This book examines the economy of the West in some detail and attempts to discover the nature of the alternatives which the region faces in the second half of the present century. In the next three chapters the history of the rise and decline of the West is sketched briefly, and the place of the Mountain West in the American economy is described. Parts Two and Three contain an analysis of the resources of the region and the organization of its economic activities. The role of the Mountain West in the economic and political life of the nation is discussed in some detail in Parts Four and Five.

In Part Six a final statement of the major thesis of the book is presented. The Mountain West is seen as a new frontier for America. The possibilities of future stagnation of the region seem great; but, on the other hand, so do the 
opportunities for development. The divide upon which we stand today need not be the last divide, if we firmly seize the opportunities which are before us. And should the major economic expansion which potentially exists in the Mountain West take place and should it be facilitated by new attitudes in government and politics, then we can truly say that in the decades ahead the West will again become a new frontier in American life-an economic frontier, a conservation frontier, and a frontier in political liberalism. 


\section{Chapter 2. The Rise of the Modern West}

The West always has held a great fascination for Americans. In the early days of the Republic the conquest of the West by trapper, explorer, and pioneer was a dominant factor in our social and economic life. Problems of the administration and control of the western areas were a constant source of concern to the government. Political clashes over Western issues and dramatic events, such as the Louisiana Purchase and the Missouri Compromise, highlight the first hundred years of our national history.

Such events were the more spectacular parts of the allpervasive long-time trend which historians call "the Westward Movement." Since 1790 our population has maintained a continuous migration toward the West. True the tide has ebbed at times, but it has never ceased even to this day. In $194^{\circ}$ the center of population of the United States was 13 miles west of the point which was the center in $193^{\circ}$; $^{1}$ and from $194^{\circ}$ to 1949, the population of the Pacific States rose

1 The center also moved 7.9 miles south. Since 1790 the center of population has moved westward by 602 miles, and is now less than 20 miles from the eastern border of Illinois. 
by nearly 5.3 millions, or 54 per cent, while the total population of the United States increased by only 13 per cent. It is certain that in $195^{\circ}$, when the next census is taken, the center of population will be found at a point west of the $194^{\circ}$ position. Nor is it impossible that eventually the westward trek of this geographical spot will bring it to the banks of the Mississippi!

As the frontier receded westward before the onslaught of the axe and the plow, the definition and concept of "The West" changed. In 1800 the eastern part of Ohio was in the "Western Reserve of Connecticut." By 1820 , Missouri was "The West." Twenty-five years later Oregon and California were the center of interest and speculation, and the Far West had come into being. Beginning in the late $5^{\circ}$ 's the mining states and territories of the Rocky Mountains gained prominence, and in the 70's and 80's the settlement of the Great Plains was undertaken. It was then that the "Wild West" of the cowboy and Indian and Buffalo Bill came into the center of the stage. This is the West toward which John Babsone Lane Soule and Horace Greeley pointed in their famous injunction to "Go West young man and grow up with the country." 2 This West was to endure for more than thirty years, its life prolonged by the building of the transcontinental railroads, and by gold and silver discoveries as late as those in Colorado in the 9o's.

2 The expression, "Go West, young man, and grow up with the country," was first used by John Babsone Lane Soule in an article in the Terre Haute (Indiana) Express in 1851. Horace Greeley in an editorial in the New York Tribune, July 13, 1865, used the phrase, and it received wide circulation. As the expression gained popularity, Greeley printed Soule's article, to show the source of his inspiration. W. J. Burke and W. D. Howe: American Authors and Books (New York, Gramercy Publishing Company, 1943), p. 281, and John Bartlett: Familiar Quotations (Boston, Little, Brown and Company, 1946), p. 505n. 


\section{A Definition of the Contemporary West}

In 189o, however, the frontier was declared officially closed and once more "The West" had to be redefined. Today, nearly a half century after the peak of the westward movement, "The West" is usually thought of as that large region, almost one-third of the country, which begins with the Great Plains, sweeps across the Rockies and the intermountain plateaus, and halts abruptly against the Sierras of California, Oregon and Washington.

It is a country which might well be called the "Mountain West," for it is dominated by a topography of gigantic mountains, vast, sweeping plains, and great areas of desert and badlands (See map). It is also conspicuously a semi-arid country, for west of the 98 th meridian, the average annual rainfall is less than 20 inches except in the high mountains. It is indeed a land of "wide open spaces"- not only because it is spacious, but also because it is sparsely peopled. Its population density is only 4.8 persons per square mile as compared with 44.2 for the whole United States.

Its economy is greatly influenced by its topography and climate. Beef cattle and sheep ranching, mining, and dry-land farming are its peculiar province. Irrigated farming is its most productive enterprise, but the general character and size of the region necessarily emphasize activity in transportation, recreation, and forestry.

Today's "West" does not include Washington, Oregon and California. These three Pacific Coast states form a distinctive region of their own, in which the influence of a moderate climate with ample rainfall has been at least as determinative as trade with the Orient and the symbolism of Hollywood. People in the West recognize this distinction clearly. Both Californians and Coloradans are sure of the distinction between "The Coast" and "The West." In fact, Mr. John 
Gunther reports in "Inside U. S. A." that he heard a lady in Portland, Oregon, say that she was "going West" on a tripto Utah!

It is, of course, unnecessary to set exact geographical boundaries for "The West" or for any other region. After all, a region is as much a concept and a tradition as it is a place. It is also a way of looking at things and a point of view, particularly where the national culture or national politics are concerned. Yet the economist as scientist and statistician cannot help feeling uncomfortable in his attempts to deal with such a vague entity as a region, so that it is desirable for purposes of analysis to define our field as closely as possible. Consequently, in this study "The West" is defined as the eight states of Montana, Idaho, Wyoming, Colorado, New Mexico, Arizona, Utah, and Nevada which constitute the Mountain States division of the United States census. This is a definition of convenience. It embraces all of the states which in their entirety clearly belong to the West. True, it excludes certain areas along the region's eastern side which are typically Western. However, the statistical problem of attempting to refine data beyond state lines, using county or minor subdivision lines instead, is of such magnitude that it was found impossible to cope with it here.

If state units are to be used there is good reason for excluding from a definition of "The West" those states from Texas to North Dakota which form the second tier of states west of the Mississippi. Often enough their western parts are "West"; but their central and eastern parts are just as definitely Middlewest (or South). Moreover, the eastern parts of these states tend to dominate the state as a whole. Hence, they have been excluded from the definition. In consequence, we have a statistical definition of an eight-state region which is designated "The Mountain West" for reasons which are obvious from a glance at the relief map of the United States. 
Frequently, generalizations about the region will spill over its statistical boundaries, but fortunately this can be done without violence to the accuracy of the generalization. The definition, then, is one of convenience. Its accuracy is satisfactory, but its use can be elastic enough to satisfy those who feel that the definition is too restricted. After all, we would not deny the right of the Texan or Oregonian to call himself "a Westerner."

\section{Economic and Political Significance of the Westward Movement}

In the short space of a century and a half the population of the whole of the United States has leaped from 4 millions to $15^{\circ}$ millions, and our wealth and productive power have multiplied in even greater proportion. This phenomenal expansion is the result of a complex of factors, and it is extremely difficult to disentangle them or to assign degrees of relative importance among them. Yet it is clear that to a large extent our national history is in essence the history of our westward migration in response to the challenge of the frontier. There, to the West, lay a tremendous store of wealth to be had for the taking; and our population grew and multiplied in response to that challenge.

As the frontier settler moved West he sent back to the older East the fruits of his conquest. First, he sent furs and gold and buffalo hides and cattle-the easily extractable wealth of the surface. Later he was able to produce and sell the fruits of field, forest, and sub-soil-wheat, corn, meat, lumber, lead, zinc, and petroleum.

Whatever the settler's activity, it created a constantly growing return flow. Into the new West the East sent goods -manufactured articles for direct consumption and capital 
goods of all kinds by which to exploit further the natural resources of the region.

Thus a continuous cycle of economic activity was generated. The East, and Europe, "exported" labor and capital to the West, and the West "exported" to the East the products which its industry wrested from a new reservoir of resources. And all the while, the frontier moved steadily westward, and "The West" itself was constantly redefined.

Two conditioning factors in this complex process stand out sharply as being of particular importance. The first is the free land policy of the federal government which had much to do with the volume and speed of the migration of population to the West. The second is the building of the transcontinental railroads, by far the most spectacular example of the effect on national expansion of capital imports into the West.

Before $179^{\circ}$, and after, there were always plenty of men who felt sure that they could better their lot if only they could move on to a place of better opportunity and make a new start under new conditions. The opening up of the American West gave such men an opportunity almost unparalled in 2000 years. If they could but break the barriers of space and means that held them where they were, there was at least a place to go.

At first the eastern states and the federal government attempted to dispose of the public domain by sale at auction to the highest bidder. It was planned to survey the land ahead of settlement and then sell the surveyed land to speculator or settler. But, by 1820 , the settlers had outrun the surveyors and the government agents, and settled where they pleased. This state of affairs was recognized in the Pre-emption Act of 1841 which allowed the pre-emptor the prior right of purchase.

But the demand for land was too great and the supply 
too large and too uncontrolled for even this generous program to work satisfactorily. A political campaign led by Westerners and supported by the working class in the East led eventually to the Homestead Act of 1862 . This act provided for the free gift to every settler of 160 acres, the only conditions being the payment of a small registration fee, and the requirement of residence and cultivation for a period of five years.

Now the flood was in full tide, swelled by the ranks of Civil War veterans after 1865 . From 1860 to 1890 the last West was settled and occupied, and by 1910 the last outposts of settlement were established. Free land in the West had drawn to it the men of the East who were to tame it to the plow, fence it in, and make it a source of wealth and power for them and for the nation.

The response to the call of free land was tremendous, but it could not have been so without the development of other factors which made it easier for men to move. Of these the railroad was by far the most important. It delivered the settler and his goods at the very spot where his 160 acres awaited him. Not only that, the railway promoter actually went seeking the settler as far away as Europe, provided him with land and gave him transportation to his new abode. In return the railroad expected among other things the privilege of carrying the farmers' produce to market. Thus, the railroad was following a calculated policy of "building ahead of the traffic" and then making sure that the traffic developed. This policy served to reverse the order of settlement between the Alleghanies and the Mississippi. There the settler, using the rivers, preceded the establishment of transportation facilities. Now, west of the Mississippi, the settler followed the transportation which was constructed ahead of him.

The railroad, however, was not only a device for increasing the mobility of labor and bringing it to exploit the 
new land; it was also the prime embodiment of that other economic process upon which the development of wealth depends - the investment of capital. New land cannot yield new wealth without the application of labor; and the effectiveness of that labor in turn depends upon the amount and quality of the capital goods it has to work with.

The railroads, then, provided the West with capital goods in the form of transportation facilities. At the same time they provided the East and Europe with an outlet for funds seeking investment. It is true that this process involved serious speculative excesses, and many of the investors lost their money. It is also true that the government was by far the largest investor, and the largest loser, in this period of railroad building. Between $185^{\circ}$ and the early $70^{\circ}$ s the federal government alone gave the railroads about 100 million acres of public land worth then about $\$ 500$ million and, in addition, loaned cash to many of the roads as an inducement to rapid construction. Thus, the government also proved to be eager to "build ahead of the traffic" and open up the new lands for settlement. The results of this policy were a quickening of the pace of economic activity throughout the nation, a tremendous increase in western population, and a significant rise in the national income.

It is worth noting that the settlement of this last frontier took place during the period of the rapid industrialization of the United States. The extension of the railway network is, itself, an important aspect of the American Industrial Revolution. At the same time there were other forms of capital investment to be made in the West and generally in other parts of the country. The new agriculturist needed tools, and later machines, to cultivate his fields. He needed fences and farms and highways. Whole towns and cities had to be built, calling for huge accumulations of capital goods in the form of dwellings, stores, warehouses, and factories. Throughout 
the United States there was a rapid movement of industrialization-of harnessing mechanical power to turn the wheels of new machines in thousands of new factories. This movement speeded the development of the West, while the West provided an outlet for much of the new machinery and manufactures of the newly industrialized society.

The influence of the West on American life is by no means confined to the economic sphere. It is equally important in the arena of politics; particularly in those cases where political controversy has centered around an economic issue. A number of noted historians led by Frederick Jackson Turner have emphasized this role of the West in the so-called frontier interpretation of American history. The essence of this thesis is perhaps best summed up by Frederic L. Paxson who argues that the influence of the West upon American politics has taken the form of a series of Western liberal revolts against Eastern conservatism:

"The first of these revolts (as we have seen) was a revolt against the English Tories with George Washington, rebel and patriot, as its personification. A generation later Thomas Jefferson, Democrat, marshalled the second western wave, and installed his dynasty. Andrew Jackson, next, with Democrats behind him, descended from the West in 1828 to take the spoils from the enemies of true Americanism. And a generation after Jackson came Abraham Lincoln, like all the rest a personification of some of the aspects of human dignity and liberal thought.

"Each generation had its wave, each had its prophet, each swept from west to east with a new message, and each left the United States somewhat more firmly set to democracy than it was before." 3

There was a fifth revolt of Western liberalism, as Paxson

${ }^{3}$ Frederic L. Paxson: When the West is Gone (New York: Henry Holt and Company, 1930), pp. 91-92. 
goes on to point out. Led by William Jennings Bryan in 1896 it stood for the interests of Western debtor farmers and against the conservative, gold-standard Easterners. The Mountain West took part in this revolt as a full-grown, fullfledged partner of other Western interests. By 1896 the mining states had reached the peak of their period of rapid settlement. Together with the Western plains of Nebraska, Kansas, and the Dakotas they constituted the actual frontier. Free coinage of silver was the major issue of the campaignat least on the surface-and this was of primary importance to the mining regions.

Nevertheless, the Mountain West was unable to gain its ends. Unlike the earlier frontier revolts, this one failed. The frontier no longer found it possible to enlist enough support in the East to win victory at the polls. In consequence, the Mountain and Plains States were forced into a long period of slow consolidation of their economic position. Slowly, and with many discouraging setbacks, they learned how to apply science and technology to dry-land farming, to irrigation, and to conservation. Slowly they came to understand the true nature of the wealth of the West and how to use it productively. Gradually they acquired the understanding and patience necessary to the application of collective effort to their problems.

And as drought, and grasshoppers, and falling prices afflicted them they retained a vigorous liberalism in their political outlook. The Western states, particularly the Dakotas, continued to sponsor liberal agrarian reforms as late as the 2o's and 3o's. The radical labor movement had its early origins in the mining states. It was there that the first clashes between labor and the "Big Business" of heavy industry took place, with the miners in coal and copper being the first to press militantly the demands of labor for humane treatment and a living wage. The West also has been a leader 
in such liberal reforms as woman suffrage, the initiative and referendum, the direct primary, and the popular election of senators. With the advocacy of such reforms as these the political liberalism of the West has continued to exert a definite influence on the economic and social policies of the entire nation.

The West of today-the Mountain West-is built upon the foundations of the past. It formed the last frontier, and it constitutes the last of the successive "Wests" which have been so important in American life. The settlement of the Mountain West marked the climax of the westward movement. Thereafter, the influence of "The West" was destined to decline in relative importance in the American scene during a period of nearly half a century. 
Chapter 3. The Decline of the Mountain West

The frontier reached the bend of the Missouri by 1821 and then proceeded to consolidate along this line during the next thirty years, all the way from Minnesota to Texas. But in the meantime the westward movement did not subside. Instead it leaped over the frontier and established new settlements in the Far West. Oregon was the first point of settlement on the Pacific Coast and by $185^{\circ}$ it was well on the way toward becoming an established society.

The year 1850 was also the first time that the census reported the existence of population in its Pacific and Mountain divisions, showing 105,891 persons in the former and 72,927 in the latter. In the next decade, $185^{1-1860}$, population in the Mountain division increased by $14^{\circ}$ per cent while in the Pacific division the increase was 322 per cent. At that time the Mountain West was still largely unsettled, but the Pacific region definitely had become established.

After 1860 the Mountain West had its turn, and for the next four decades its population grew at a faster rate than that of the Pacific. Even so, the total population of the eight 
Mountain states in 1900 was substantially less than that of the three Pacific states. (Mountain: 1,674,657; Pacific: 2,416,692).

Then in 1900 for the second time the westward movement began to leap over the Mountain states to the Pacific Coast beyond. Ever since the turn of the century, population on the Pacific has grown very rapidly while the rate of growth in the Mountain West has been slowing down. In each decade after 1900 the West grew at a slower rate than in the previous decade; and in the last twenty-five years the Mountain West has managed only to maintain a stable percentage of the total United States population-approximately 3 per cent (See Chart 1).

During and after World War II, 1940-1949, population in the Mountain West grew by only 16 per cent while our total population grew by 13 per cent, and the population of the three Pacific states by 54 per cent. By 1949 the population of these three states amounted to over 14 millions, while there were only about 4.8 millions in the eight states of the Mountain West. This is leap-frogging with a vengeance-a modern repetition and intensification of the history of the $1840^{\prime}$ 's and $50^{\circ}$ 's.

The contemporary decline of the Mountain West is manifest not only in its population, but also in the income which the inhabitants receive. Only in the South do we find a region where per capita income is lower than that of the Mountain region. From 1929, when data were first made available, to $194^{\circ}$ most of the states of the Mountain West received per capita incomes anywhere from 10 to $4^{\circ}$ per cent below the national average. Income in the Pacific region, on the other hand, usually has exceeded the national average by about 25 per cent. This fact goes far to explain the greater attractiveness of the Pacific to our westward-moving population. It is true that during the war and post-war inflation, 


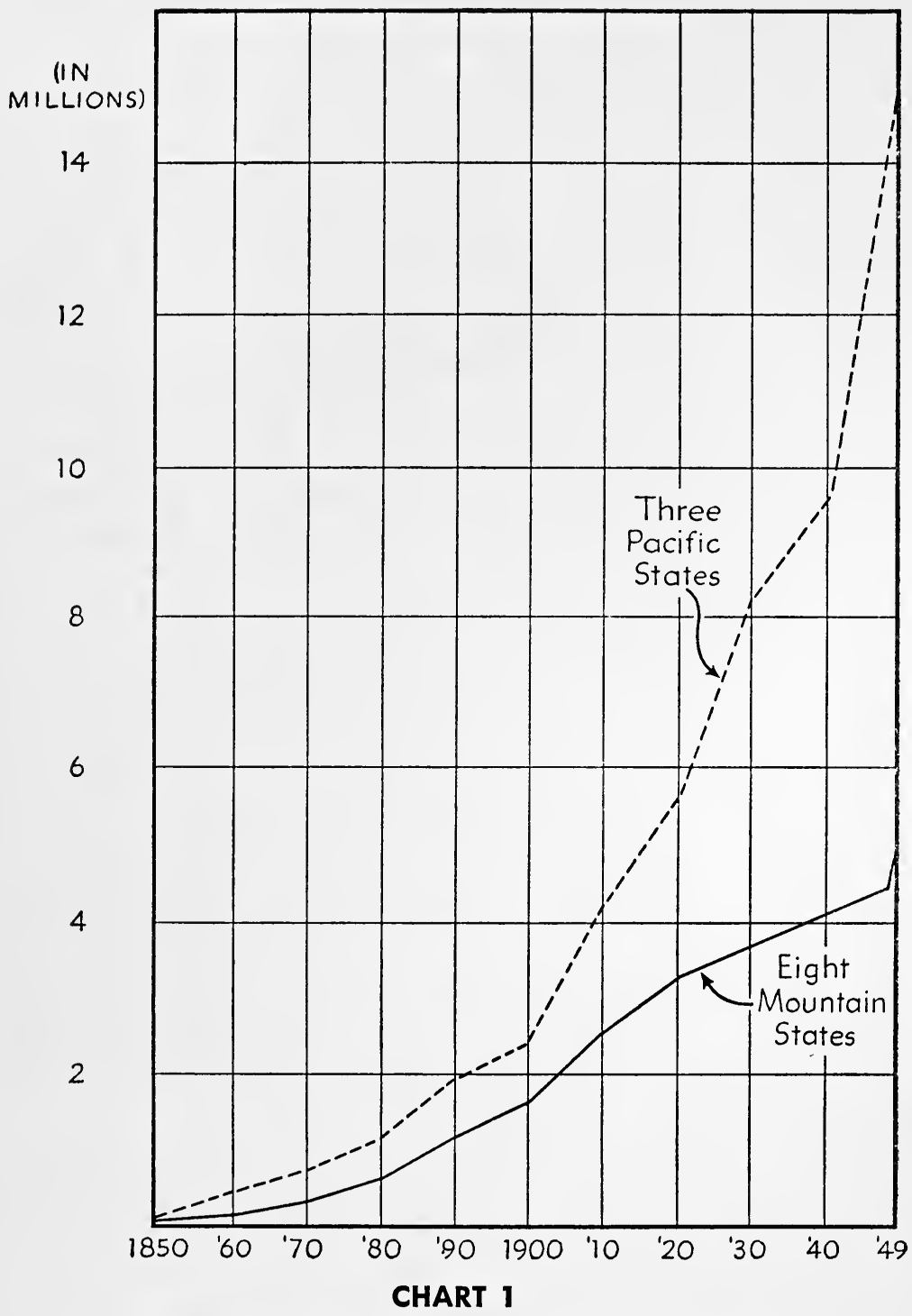

Growth of Population in the West-1850-1949

Source: Statistical Abstract of the United States. 1946. pp. 6-7 Bureau of the Census, Population Series P-25, No. 14. 
TABLe I. Population in the West 1850-1949 (in millions)

$\begin{array}{lcc} & \text { Mountain } & \text { Pacific } \\ \text { I850 } & .07 & . \text { I I } \\ \text { I860 } & .17 & .44 \\ \text { I870 } & .32 & .68 \\ \text { I880 } & .65 & \text { I.I } \\ \text { I890 } & \text { I.2 } & \text { I.9 } \\ \text { I900 } & 1.7 & 2.4 \\ \text { I910 } & 2.6 & 4.2 \\ \text { I920 } & 3.3 & 5.6 \\ \text { I930 } & 3.7 & 8.2 \\ \text { I940 } & 4.2 & 9.7 \\ \text { I949 } & 4.8 & \text { I } 4.9\end{array}$

per capita income in the Mountain States has improved under the influence of the great increase in agricultural prices (See Chapter 10). Nevertheless, it is correct to say that the region as a whole is characterized by a relatively low per capita income. ${ }^{1}$ The failure of the region to develop a type of economic activity which can yield a satisfactory income to its inhabitants is one of the chief signs of the present decline of the West.

\section{The Effects of the War}

Another important indication of the lagging expansion of the Mountain West is found in the impact of World War II on the region. After 1941, the war became the source of a tremendous stimulation of economic activity throughout the United States. In the Mountain West, the tempo of agriculturial and minerals production was quickened sharply.

${ }^{1}$ In this group Nevada has always been an exception, with a per capita income approximating that of the coast states. Also Wyoming has usually managed to equal or slightly exceed the national average; and Montana has achieved this distinction in five years out of the last eighteen (See Chapter 10). 
New war plants were built and manufacturing expanded significantly. Training camps and air bases dotted the region. Mountain troops practiced Alpine warfare at 11,00o feet from their base at Pando, Colorado; while down in Los Alamos, New Mexico, a new, heavily guarded, and secret city grew up around the atom.

The Mountain West was able to make a substantial, even vital, contribution to the national war effort. Yet, for the region as a whole, the war had very little effect on its relative economic position. While the Pacific Coast and Texas forged ahead, the share of the Mountain West in the national total of various kinds of economic activity remained remarkably constant throughout the war. Although the wartime expansion of employment was great, the Mountain West actually lost position in total nonagricultural employment, while gaining slightly in the relative importance of its manufacturing employment. ${ }^{2}$ By 1945 , the pre-war income position of the region had risen closer to the national average, but the improvement was almost entirely in "net agricultural income" because salary and wage payments declined relative to the rest of the nation. The region's percentage of the national production of minerals and livestock actually declined, while lumber production little more than held its own. Bank deposits in the region showed a substantial gain over the national increase in deposits. This again is largely a reflection of increased agricultural income.

If measured in terms of prime contracts the region's contribution to direct war production appears to be very small indeed, amounting to only 0.5 per cent of the national total. This figure is also small in comparison with the pre-war share of the Mountain West in manufacturing production and investment-1.4 per cent of the national total. It should be West.

2See Appendix Table 14-Impact of the War on the Mountain 
noted that these figures take no account of subcontracts, and consequently, understate the region's contribution. It is believed that subcontracting in the region was substantial, but no data are available by which to estimate it.

A very important aspect of the impact of the war upon a region is the addition to its capital equipment of new plants erected by the government for war purposes. In this, the Mountain West apparently realized substantial gains. In 1939, only 1.3 per cent of total national investment in new manufacturing plants was made in the Mountain West, yet during the war the region received 4.2 per cent of the new industrial facilities created in response to the demands of war production. This creation of so much new plant between 1941 and 1945 gave promise of a substantial modification of the economic structure of the Mountain West in the post-war era.

By the end of 1947 such promise hardly had been realized. Reconversion in the Mountain West lagged behind the rest of the country. Of forty-four industrial plants listed in the region by the office of Real Property Disposal, WAA, only about one-third had been reconverted by December, 1947. Most of these were small plants; and only two were large enough to make a substantial contribution to industrial progress. These were the great Geneva Steel Plant of Provo, Utah, which is operated by U. S. Steel, and the Rocky Mountain Arsenal (chemicals) which was reconverted in part by the Colorado Fuel and Iron Company and some smaller lessors.

During 1948 reconversion activities did begin to catch up with progress in the rest of the country. The ordnance plant in Salt Lake City became partially utilized by private enterprises for warehouse and manufacturing space. In Pueblo, a part of the ordnance depot was converted to the large-scale manufacture of pistons. In Nevada, the \$140 mil- 
lion plant of Basic Magnesium Inc. returned to operationsignificantly, under the direct ownership and management of the State of Nevada rather than in private hands. By contrast the largest ordnance plant in the region, in Denver, still remained unconverted to industry in mid-1949; although it was occupied by Federal government offices and warehouses. Four years after VJ Day the large accretion of manufacturing capital brought to the West by the war was not fully transformed to peacetime uses, and the rate of reconversion had been distinctly slower than in other regions.

On the West Coast, by contrast, many new manufacturing industries began to develop soon after VE Day-from garments in Hollywood and steel in Fontana, to aluminum and alcohol in Washington. Since the war the Pacific states have initiated or projected nearly a billion dollars of new investment in industrial plant, and much of the steel and aluminum plant capacity created during the war has remained in peacetime operation. ${ }^{3}$ In 1946 , the Pacific states accounted for 7.87 per cent of the nation's manufacturing payrolls, as compared with 0.91 per cent in the Mountain States. ${ }^{4}$ Once more the Mountain West has been "skipped over;" this time in the field of manufacturing-one of the most important aspects of the contemporary westward movement.

\section{The Question of Water}

The greatest present danger, however, is that the expansion of the Pacific Coast may not only postpone Western development but might actually submerge the region per-

${ }^{3}$ An interesting, brief account of the industrialization of the West Coast is found in J. D. Zellerbach: "Heavy Industry New Factor on Pacific Coast," Digest, Committee for Economic Development, 1:6, November, 1947.

4 United States Department of Commerce: Survey of Current Business, 27:14, August, 1947. 
manently and reduce it to a position of secondary economic importance. Nowhere is this danger more threatening than in the crucial matter of water. To a great extent the future of the West lies in the development of hydroelectric power and irrigated agriculture. Water is scarce and precious, and from the beginning men have competed vigorously, and even fought, over its division.

States and regions, too, have entered this conflict; and today California seems determined to capture the lion's share of the waters of the Colorado River. The Colorado River Compact of 1922 reserved 71/2 million acre feet of water for use in the upper basin of the Colorado. ${ }^{5}$ California is a signatory to this pact. Yet the State and the City of Los Angeles already have constructed canals and aqueducts sufficient to carry all of the water of the Colorado across the desert to California; and, having constructed these excessively large facilities, California now claims that she is entitled to as much water as her facilities can carry. ${ }^{6}$ Should she be able to establish this claim and nullify the Compact, development of the resources of Colorado, Wyoming, and Arizona would be permanently prevented, and the Mountain West would be forever removed from the main currents of American economic life.

A single illustration is sufficient to show how costly such retardation of Western development could be, both to the region and to the entire nation. Already the depletion of our petroleum reserves is a matter for serious concern, even in the immediate future; and the exhaustion of these reserves in

5 Article IIIa, Colorado River Compact of 1922. A summary of the Compact as well as of the events leading up to its formation can be found in United States Department of the Interior, Bureau of Reclamation, The Colorado River (Washington D. C., March, 1946), pp. 55-67.

6 Ben Avery: "Showdown Near in West's Water Fight," The Denver Post, December 12, 1947. See also Raymond Matthew: California's Stake in the Colorado River (Sacramento, California: Colorado River Board of California, 1947), pp. 3-9. 
twenty to thirty years is now freely predicted. ${ }^{7}$ Fortunately, substitutes are available because it is possible to extract oil from shale, or from coal. An announcement by the Bureau of Mines in 1947 stated that it had become practicable to extract oil from shale at a cost of about $\$ 2.5^{\circ}$ per barrel, and that further technological improvements were imminent. ${ }^{8}$ In 1949 the results of continued experimentation in the mining and processing of oil-shale were demonstrated at Rifle, Colorado, during a special test run in September and October. On September 21, Secretary of the Interior Julius Krug stated that technical efficiency had been increased and costs lowered sufficiently to justify the commercial production of synthetic oil from shale. ${ }^{9}$

The nation's shale oil deposits are located in Utah, Wyoming, and Colorado, with the most readily available deposits lying in the valley of the Colorado River in western Colorado. The intensive development of these deposits will revolutionize the economy of the area. According to J. D. Lankford of the Bureau of Mines:

"We would have to revise our thinking on highways in the area, and would have to get an altogether new picture of water supply.

"Whole new cities would have to be built to accommodate manpower needs for an operation which would produce-let us say 100,00o barrels of oil a day.

"It would mean a complete transformation of this entire valley along the Colorado River." 10

This development depends largely upon the availability of water. The industrial processes themselves require water; and without water the population of the West cannot

${ }^{7}$ Frederic J. Dewhurst, and others: America's Needs and Resources (New York; Twentieth Century Fund, 1947), pp. 587-88.

8 The Denver Post, December 17, 1947.

${ }^{9}$ Op. cit. September 21, 1949.

10 Op. cit. (italics mine). 
grow in response to the demands for manpower to operate the new industries.

Thus the issue is joined. The struggle over the waters of the Colorado River is of vital importance to the West. The regional rivalries of the West have reached a definitive stage. In the past the Mountain West could afford to wait while the westward movement by-passed the intermountain area and the Pacific states expanded. The resources were there, and in time their development would come. Now things are different. Resources are becoming scarce. In particular, there is not enough water for all of the semi-arid West. What California takes now the Mountain West will lose forever. Without water the Mountain West cannot develop its own resources, nor find employment for its own population. Failing to build its own regional industries, it will remain a backward area. Its raw materials will be extracted and moved away as quickly as possible, leaving behind ghost towns and a stranded population. However, if the Mountain West begins now to develop its own resources it can become a balanced and integrated sector of the expanding national economy. Which is the West to be-American backwoods or American frontier! 
Chapter 4. America's Stake in the West

The American people have an important stake in the future of the western part of the nation. Failure to develop the West's resources would be a calamity for the region. But more important, it would jeopardize our national program of full utilization of resources and economic stability. The depression of the 3o's showed us the deteriorating effects of unemployment on our social fabric and made us resolve to use every means to insure continued high-level employment in the future. The war, which followed, showed us that full production was possible, and that our economy could yield a level of living greatly superior to our already high standard of material well-being.

The implications of our wartime experience have been carefully explored in one of the most significant economic studies in recent years-the Twentieth Century Fund's important work, America's Needs and Resources. In this study an attempt is made to estimate the "needs" and the "demands" of the American people in 1950 and 1960; and to 
make an inventory of the natural and capital resources which would be necessary to satisfy those demands. The major conclusion of the study is that, with high-level employment and normal improvements in labor productivity, our economy can produce a gross national product of $\$ 177$ billion in $195^{\circ}$ and $\$ 202$ billion in 1960 , as compared with a national product of $\$ 128$ billion in pre-war $19400^{1}$ In other words by $195^{\circ}$ our "real" income in goods and services can be nearly 40 per cent greater than in 1940; and by 1960 it can be about $5^{8}$ per cent greater than it had been twenty years earlier.

It is obvious that in order to achieve these highly desirable results we must exploit our natural resources, and consume them in even larger amounts than in the past. Also since many of these resources are exhaustible they must not be exploited recklessly, but must be utilized with proper consideration for the best methods for their conservation and replacement. It is here that the Mountain West, with its vast store of underdeveloped resources, can make a very significant contribution to the national welfare. Western resources will be essential to the program of high-level employment and consumption envisaged in America's Needs and Resources.

There are three important classes of resources in which the Mountain West can be expected to make a greater relative contribution in $195^{\circ}$ and 1960 than it formerly yielded to the national economy. These resources are agricultural land, hydroelectric power, and minerals.

Dr. Louis Bean estimates, in America's Needs and Resources, that in order to produce the food and fiber which the fully employed population of $195^{\circ}$ can buy, some 40 million acres must be harvested in addition to the 321 million acres harvested in 1940. Dr. Bean's projections for 1960 vary with his various assumptions concerning increases in agricultural prices.

1 Dewhurst, op. cit., Table 22, p. $65^{8}$. All figures are in terms of 1944 
productivity. His extreme assumptions call for a harvested acreage of 390 millions by $1960 .^{2}$

How much of this required increase in harvested cropland should be provided by the Mountain West? In 1945 the harvested acreage in the Mountain West amounted to 23.1 million acres, which was 6.5 per cent of the national total. Thus, the region's proportionate share of the increase rerequired for $195^{\circ}$ would be 2.6 million acres. However, there are several good reasons for taking the position that it would be in the national interest to draw more heavily on the West for new cropland, and eventually to find within these eight states as much as 10 per cent of the national total of cropland harvested.

\section{Productivity of Western Agriculture}

Productivity in agriculture is high in the Mountain West. The gross value of agricultural products per "manequivalent worker" 3 in the Mountain States in 1939 was $\$ 1,423$ as compared with a national average gross product of $\$ 942 .{ }^{4}$ Net returns to agricultural labor and management in the Mountain States were $\$ 488$ per "man-equivalent worker," which was substantially above the U. S. average of $\$ 35^{6}$. A third measure of agricultural productivity, "value added by the agricultural production process," also indicates a high productivity in the Mountain West: \$1,204 per "man-equiv-

2 Ibid., Chapter XXIV, "Agricultural Capacity" by Louis H. Bean, especially pp. 6o8-10. These estimates also take account of exports.

3 The statistical concept of "man-equivalent worker" represents an attempt to relate the labor input of such workers as those over $6_{5}$ and unpaid family workers to the common denominator of the labor input of the average able-bodied farm operator.

4 These figures and the others in this paragraph are from Louis $\mathrm{J}$. Ducoff and Margaret Jarman Hagood: Differentials in Productivity and in Farm Income of Agricultural Workers by Size of Enterprise and by Regions. (mimeographed) United States Department of Agriculture, Bureau of Agricultural Economics. (Washington, D. C., 1944). 
alent worker" as compared with a national average of $\$ 867$ (See Appendix Table 15). Only one region, the Pacific, was superior in productivity to the Mountain region, while all the others were of definitely lower productivity.

Any program of agricultural expansion for post-war needs for food and fiber should be planned to take the maximum advantage of the higher productivity of Western agriculture. On the basis of such common-sense planning the Mountain West should be called upon to increase its quota of the national total of harvested acreage beyond the present 6.5 per cent.

A further advantage to the national economy deriving from the use of Western lands is found in the fact that most of the land added to cultivation in the West will be irrigated land. While there are some areas in which dry-land farming could be increased by use of new techniques of cultivation, much of the nonirrigated land brought into cultivation during the war should be returned to pasture, in order to produce grass and beef to meet the growing demands for meat of a prosperous population. Grass is also a much better safeguard against wind erosion than even the best methods of dry-land cultivation.

By contrast there is great advantage in adding irrigated acreage to our stock of cropland, because such land is capable of being used with a high degree of productivity. The superior productivity of irrigated land is derived from the higher degree of control which the farmer can exercise in its use. Irrigation makes it possible for the cultivator to control one of the most important factors in plant growth-moisture. As a result of the farmer's ability to supply water at the time and in the amounts needed, he can count on high yields per acre and can afford the risk of a heavy investment in the intensive cultivation of the land. The productivity of irrigated land is well illustrated by a comparison made by the Montana 
Agricultural Experiment Station. In Montana only about 2 per cent of the total land area is irrigated, but $3^{6}$ per cent of the value of all farm lands (and buildings) is accounted for by irrigated lands, and nearly one-third of the people on farms in the state live on irrigated farms or ranches. ${ }^{5}$ Irrigation creates economic oases in the midst of virtual desert.

The factor of control, plus general climatic and soil conditions, makes irrigated land particularly well-adapted to the production of vegetables and fruit. And these are precisely the products which will be in great demand in a high-level income economy. Moreover, Western irrigated agriculture is closely integrated with the production of beef and mutton. Irrigated cropland and pastures provide supplementary feed for range livestock, and make possible a high degree of efficiency in the production of meat animals. Here again, future production is well-adapted to future demand; for it is certain that with the high-level of income projected for 1950-6o the demand for meat will be substantially greater than it was in the decade preceding World War II. Therefore, if it is necessary to add to our harvested cropland in order to supply the food and fiber requirements of a high-income society, it is particularly desirable to bring into cultivation new irrigated land.

\section{Mineral Resources of the West}

The contribution of the Mountain West to the mineral requirements of a high-productivity economy in 1960 is, perhaps, of even greater importance than the region's contribution of food and fiber. Most of our national production of

5 P. L. Slagsvold and J. D. Mathews: Some Economic and Social Aspects of Irrigation in Montana. Montana Agricultural Experiment Station Bulletin No. 354, p. 3, cited by Roland R. Renne: Land Economics (New York, Harper and Brothers, 1947), p. 252n. 
non-ferrous minerals comes from the Mountain States and most of our reserves are there (See Chapter 6). In addition, the bulk of our reserves of potash and phosphates are found in the Mountain States. As fertilizer requirements for rebuilding our depleted soils mount, these reserves must be drawn upon in greater and greater quantity.

Still more important, the Mountain States contain a large percentage of the nation's basic reserves of the energyproducing minerals. Within these eight states is found 42.6 per cent of our reserves of coal, 1 oo per cent of the nation's oil shale, and 7.1 per cent of its petroleum reserves.

The importance of mineral energy in our economy recently has been emphasized by J. Frederic Dewhurst, editor of America's Needs and Resources. His explanation of the great rise in American wealth and productivity since $185^{\circ}$ is worth quoting at some length:

"This lessening of human toil and advancement of human welfare has been made possible by harnessing tremendous amounts of mineral energy to multiply human effort-with all that this implies in terms of the application of scientific discoveries, engineering and managerial skills and large-scale capital investment. . . . In 1850, when an American workman had to work an hour, on the average, to produce 23 cents worth of goods, he had the help of only half a horsepower of energy from animals and minerals. By 1900 his hourly output was twice as large, and his effort was supplemented by nearly twice as much nonhuman power. Output per man-hour had risen to nearly a dollar by 1940, but the nonhuman energy used was now nearly 2.7 horsepowerhours for each hour of human effort. By 1960 , if these trends continue, we will be producing six times as much per manhour as in 1850-with each hour of human effort supplemented by nearly eight times as much nonhuman energy.

"Until the end of the nineteenth century, animals were more important than minerals in supplementing human effort, but their contribution is no longer significant. With 
the rapid development of electric power and the internalcombustion engine since 1900, minerals have become our dominant source of work energy. In 1940 we used seven times as much mineral energy per man-hour as in 1900 and 70 times as much as in $185^{\circ}$. By 1960 , with minerals doing nearly 99 per cent of our nonhuman work for us, we will be using over 100 times as much mineral energy per man-hour as in $1850 . " 6$

In the light of these facts the importance of the Mountain West's reserves of coal and oil-shale becomes obvious. As our dwindling petroleum supply is exhausted we must turn to these reserves for the source of our mineral energy-much of it in the form of synthetic petroleum. Nor is the day far off; as we saw in the previous chapter, Secretary of the Interior Krug already has called for an immediate start on the creation of a nine-billion-dollar synthetic oil industry, and much of this industry must be located in the Mountain West.

However, the West cannot be satisfied with the mere creation of a new extractive industry in the region, no matter how extensive it might be. The day of the ruthless exploitation of our natural resources belongs to the past. Future policy should be based on the concept of an extractive industry surrounded by its natural auxiliaries, producing byproducts and allied products. Thus, for example, the production of synthetic petroleum makes possible the creation of a number of satellite chemical industries, turning out such products as pyridine, cresylic acid, and ammonium sulfate.

In agriculture, too, the increase in production should be accompanied by the growth of industries engaged in the processing of the raw materials of the fields and forests. Such an industry should be designed to serve both the regional and national market with prepared animal feeds, quick-frozen vegetables and fruits, and dressed and prepared meat products-to name only the more obvious examples. If a policy ${ }^{6}$ Dewhurst, op. cit., pp. 683-4. 
of this kind is followed the Mountain West will develop into a well-balanced regional economy, properly integrated into the national economy, and making a maximum contribution to the national well-being. Surely such a program is to be preferred infinitely to the perpetuation in the West of a rawmaterials, colonial economy, exploited by absentee corporations for their own direct benefit and for the indirect gain of more-favored regions.

\section{Hydroelectric Power}

One factor which will greatly facilitate the growth of a balanced, raw materials-manufacturing economy in the West is its possession of a large potential of cheap hydroelectric power. Already the region's production of hydroelectric power is $61 / 2$ times greater than its production of fuel-generated power. Yet it possesses 8 million horsepower of underdeveloped power potential which awaits the construction of dams, reservoirs, generators, and transmission lines. Its total potential amounts to nearly 25 per cent of the entire country's potential of hydroelectric power.

We now have extensive evidence, in the experiences of the Tennessee Valley and the Columbia Basin, of the importance of abundant electric power for regional development. Cheap power facilitates the creation of manufacturing in backward regions. It also can be used to improve efficiency in the production and refining of minerals, and it has numerous uses in agriculture.

Hydroelectric energy is a uniquely valuable source of mechanical power. Falling water is not consumed by the turbines it propels, but goes on to do other useful work, such as irrigating the semi-arid fields in the West. Since the energy of the streams is renewable rather than exhaustible, hydro- 
electric power provides a valuable complement to fuel generated power. Every kilowatt of hydroelectricity is a net addition to our energy pool, with no corresponding loss beyond the slow depreciation of the physical installations themselves. Such power is of particular value in a high-energy-consuming economy.

National policy should call for the rapid achievement of optimum hydroelectric power production in the West as a major part of an integrated program of reclamation, irrigation and conservation, and national defense. Unfortunately, such a program is not yet crystallized. The political opposition of the private power interests is strong; and for this and other reasons, government agencies themselves have been timid and ultra-conservative in their estimates of power requirements. What the West and the nation needs, instead, is a vigorous, imaginative and courageous policy of "building ahead of the traffic," analogous to the railroad policies of nearly a century ago.

The Mountain West frequently has been compared with Switzerland. ' Both are regions of superlative natural beauty, and consequently are centers of recreation and travel. But the analogy need not rest there. Switzerland is a highly industrialized economy. Manufacturing and processing are closely integrated with agriculture and raw materials production. Switzerland has its large cities, but it also has many smaller towns with numerous factories set in park-like surroundings.

The Mountain States of America are far richer than Switzerland in raw materials. It is not an idle dream to envisage an American Switzerland, producing raw materials for the national market and processing many of them beyond the primary stages. Its people could reside in small manufactur-

${ }^{7}$ One such comparison which is made use of here is that of $\mathrm{J}$. Russell Smith and M. Ogden Phillips: North America (New York, Harcourt, Brace, and Company, 1940). 

ing towns similar to those of Switzerland, scattered through the irrigated valleys of the region. In most of these towns the climate would be far more agreeable than in the larger part of continental United States; and the inhabitants would have easy access to recreational areas of high psychic valueski tows, trout streams, and magnificent scenic drives.

Such a region would be a national asset because it would be infinitely more productive, economically and socially, than a region of drab mining towns and wasted land. The population of the Mountain West is now only about $4 \frac{1}{2}$ millions. Under the conditions of integrated industrialization and resource exploitation envisioned here, its population could easily rise to 8-10 millions. Even then, the density of population would still be only 8.6 per square mile, as contrasted to 5 2.o for the rest of the United States. With such a program for the West, Greeley's advice of a century ago would no longer be a historical curiosity embalmed in Bartlett's Familiar Quotations. Instead it would once more become sound advice and a living reality for millions of Americans in whom the spirit of the pioneer still lives. 
Part $\mid \begin{aligned} & \text { THE } \\ & \text { Tho } \\ & \text { RESOURCES }\end{aligned}$ 
Chapter
Regional Characteristics of the Mountain
West

The eight states of the Mountain West, taken together, form a region. No two of these states are exactly alike, yet they resemble each other in many ways and the similarities among them are more numerous than the differences. Also, when any of these eight states is compared with any of the other forty the dissimilarities between the states so compared are seen to be greater than the likenesses. ${ }^{1}$ This is true of comparisons of the physical, economic, or cultural characteristics of the states concerned. When the topography and climate of the Mountain States are examined, or the economic resources classified, and the occupations of the people described it is found that this large area of the United States is essentially homogeneous. The region even exhibits cultural characteristics which are uniquely its own. Although its people are "Americans" they are also "Westerners," and as such differ from their fellow Americans in New England or the South.

1 The difficulties of the precise delineation of the boundaries of a region were discussed in Chapter 2. In this book it has been found convenient to regard the eight Mountain States as a distinctive region. Of course other groupings are possible. The best known and most authoritative is that of Odum and Moore in American Regionalism. 


\section{Physical Characteristics of the Mountain West}

The two basic physical features which affect the Mountain West are land elevation and climate. A second glance at the relief map in Chapter 1 is worth while because of the impression it gives of the overwhelming predominance of mountainous areas. This impression is hardly correct unless supplemented by the companion impression of vastness and space-an impression which is created not only by the towering mountain peaks but also by the wide sweep of valley and plateau.

The climate of the region also exhibits a high degree of homogeneity. Its chief feature is, of course, the semi-arid to arid character of the entire region, with the exception of the high mountains where precipitation is heavier. The eightstate region embraces most of that great area of the United States which lies west of the 20 inch rainfall line (shown on Map 2 in heavy black). The region also includes most of the desert areas of the country, with rainfall of less than ten inches annually.

The lack of rainfall is a basic determinant of plant life and of agriculture. Forests grow where rainfall is sufficient, but even on the highest mountain slopes of the region the rainfall is much less than that of the Pacific Northwest, where our major forests are located. In non-forested areas, grass or sagebrush grow on fertile soil simply because there is not enough moisture to maintain familiar plant life. In consequence agriculture must be adapted to the limitations of the region; and the regional boundaries coincide very closely with the great agricultural region designated as "Grazing and Irrigated Crops." (See Map 3).

Inter-regional variations in mean annual temperature are much greater than variations in rainfall, since the region extends for 1,220 miles from its northern to its southern 


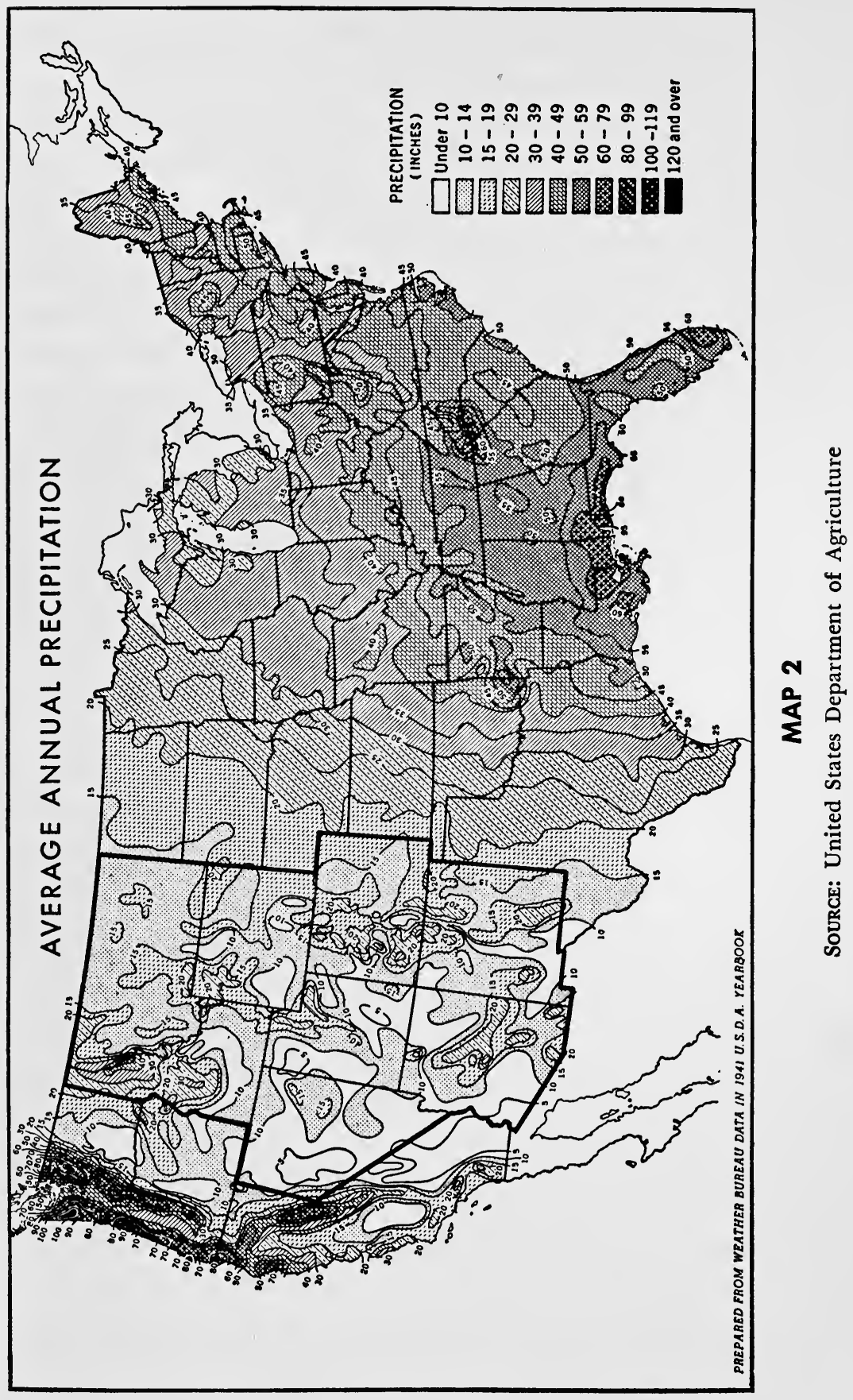


border. Temperature differences permit the growth of cotton in the south of Arizona and New Mexico, while allowing the sugar beet to thrive more abundantly in the north. At the same time every state of the region has a wide range of climate within its own borders by virtue of the effects of elevation on temperature, rainfall, and vegetation. Each state has relatively low-lying valleys, upland plateaus, mountain peaks, and rugged terrane reaching above timberline. This general pattern is repeated everywhere throughout the region and makes for the homogeneity of the area.

\section{Economic Characteristics of the Region}

The economy of the Mountain West probably is more directly influenced by the physical environment than any other region of the United States. Topography and climate determine the type of agriculture and its location, whether in irrigated valleys, open range land, or forests. The location of minerals influences the location of population as well as the occupations of a significant number of the labor force. The great extent of the region results in the relative emphasis on transportation and trade in the economy. Space, topography, and climate also create the recreational appeal of the West.

The agriculture of the region is a combination of a livestock economy with an irrigated crop agriculture. Dry-land farming also exists and often creates economic problems because of its instability. However, irrigated farming and ranching are on the whole much more productive and, consequently, of dominating importance.

Map 4 shows the five principal crops of each state in the region expressed as a percentage of national production. Hay and forage is the most valuable crop for the region as a whole. 


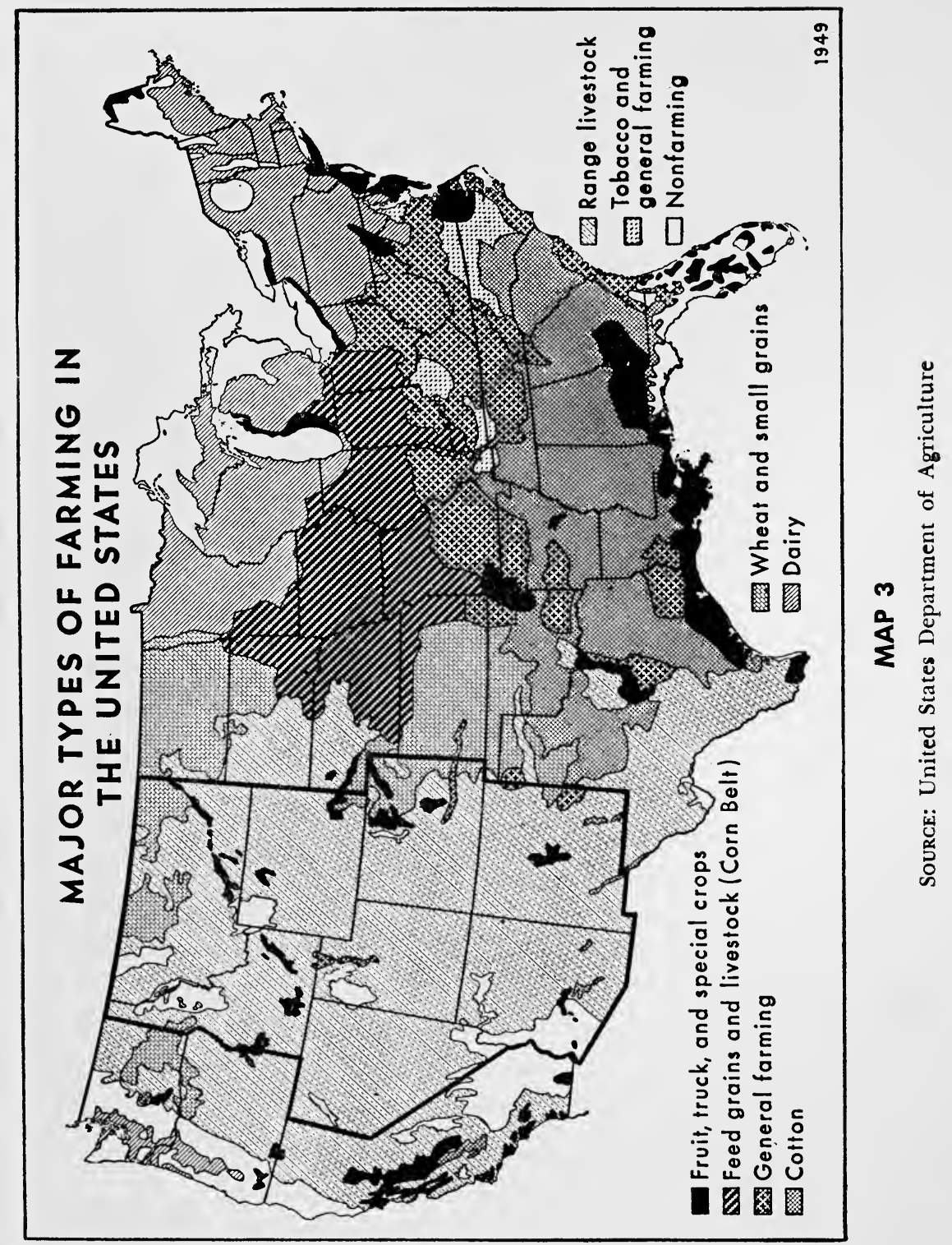


In 1939 its value was estimated at $\$ 72$ millions. ${ }^{2}$ Wheat was the second principal crop with a value of $\$ 5^{2}$ millions. Sugar and potatoes tied for third place, each being valued at approximately $\$ 21$ millions. Cotton (\$19 millions) stood fourth.

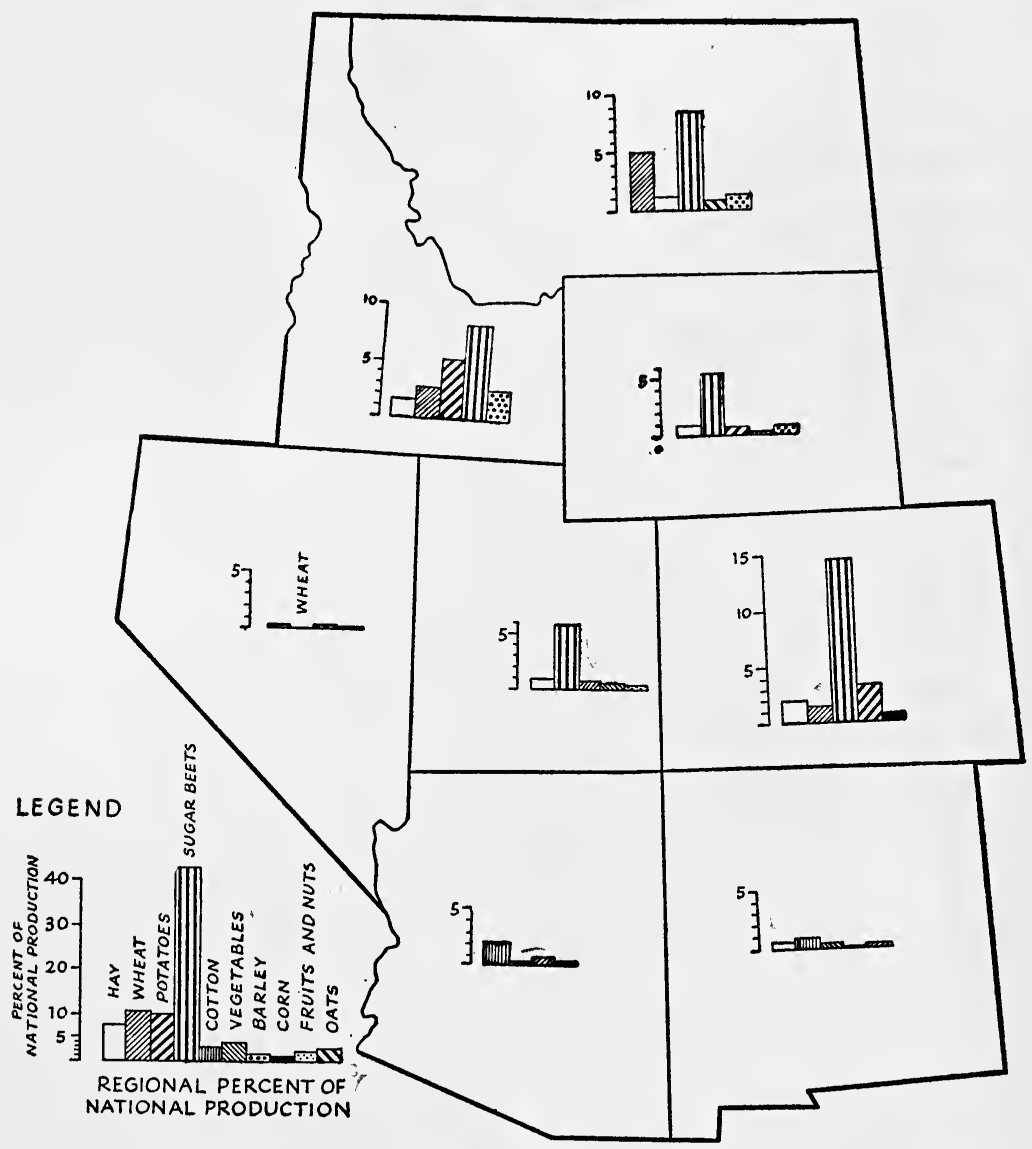

MAP 4

Value of Principal Crops of the Mountain West-1939. Shown as Percentages of National Production

Source: United States Census of 1940

2 The figures for crops and livestock cited in this chapter are for 1939 and are taken from the Census of 1940. They are used as a representation of a typical pre-war year. 
Corn and barley were followed by vegetables with a value of $\$ 15$ millions and fruit and nuts with \$9 millions.

When we look at the regional crop production relative to the rest of the nation, we find an interesting situation. Except for sugar beets, the region does not seem to contribute significantly to the total national production of crops. It produces about 10 per cent of our wheat and potatoes and less than 5 per cent of our fruits and vegetables. Its total production of crops averages about 6 per cent of the value of national output.

As might be expected from the physical characteristics of the region, the livestock industry is more important both regionally and nationally than crop agriculture. In seven of the eight states income from livestock marketings exceeds income from crops. In Nevada the former is five or six times greater; and even in Colorado, which is the largest producer of crops, livestock returns are greater. For the region as a whole, livestock accounts for $60-65$ per cent of the cash income from farm marketings, with crops accounting for $35^{-40}$ per cent.

The livestock marketed in the Mountain West is mainly beef cattle and sheep, although swine, chickens, and turkeys are also produced and sold. Since 1900 the region has accounted for about 15 per cent of the national population of beef cattle, i.e. "cattle other than cows kept for milk." At present about one-third of the nation's stock sheep are found in the Mountain West. From 1900 to 1930 the region accounted for 40-45 per cent of our total sheep population. Apparently an eastward shift of the center of the nation's sheep population is under way.

The cattle and sheep industry, like the mining industry, has left a deep imprint upon the social and political life of the West. The cultural manifestations of the industry have spread beyond the boundaries of the region to become in- 
fused in the national culture, as everyone who has ever seen a "Western" movie knows. It is perhaps not so well known that the Western cattle and wool lobbies in Washington are among the more successful of those who seek special consideration in national policy determination.

Forests occupy a significant place in the economy of the region. Their production of lumber is not large, amounting to less than 6 per cent of the national output. However, the importance of forests in the West cannot be measured by the value of their present yields of timber. Forests provide large grazing areas for the livestock industry. Even more important, perhaps, they provide the watershed for irrigated agriculture. Map 5 shows the forest areas of the Mountain West in relation to the approximate areas of irrigation in the region. A well-managed forest stores the precious water and releases it gradually for use in irrigation. Forests also are the natural habitat of wild life and, when combined with high mountains and a dry, invigorating climate, the forest creates an ideal environment for recreation.

As one looks at the physical resources base of the Western economy, an overwhelming impression of the high degree of integration among the various aspects of the economy emerges. Forests, water, irrigation, and ranching are knitted together into a single fabric. This impression is further reinforced when the factor of hydroelectric power is added to the picture. The falling water of the West must be controlled in order to irrigate the rich but arid soil, and in order to prevent costly erosion. It is relatively simple to extend this control of water to include the generation of electric power. Already the eight states of the region use water power to produce 87 per cent of their total electric power. Nevertheless, the power resources of the region have hardly been touched. The estimated power potential for the region is seven or eight times greater than its present production of hydroelectric 


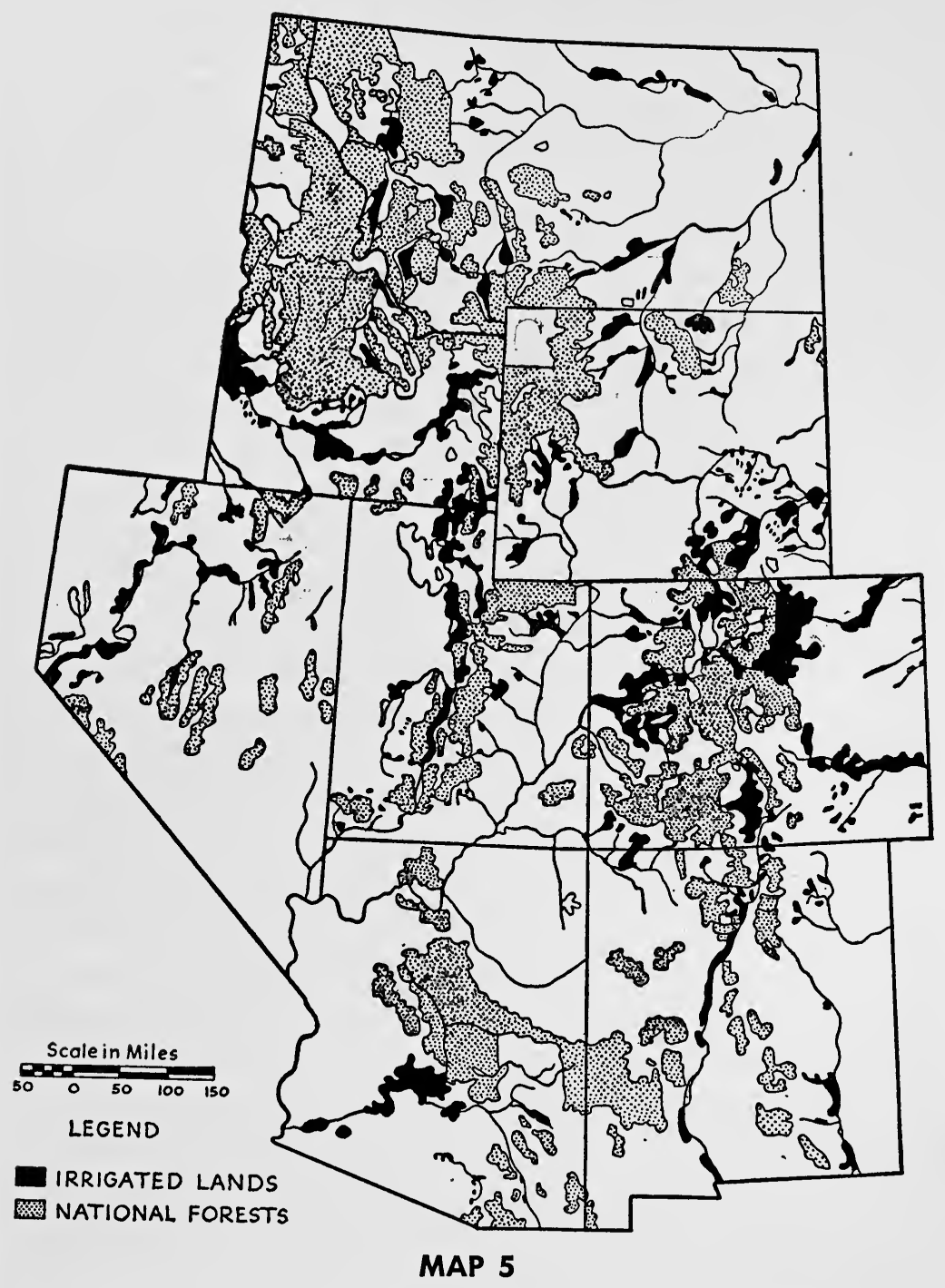

Forests and Approximate Irrigated Areas of the Mountain West showing Relation between National Forests and Irrigated Lands

Source: Adapted from North America by Smith and Phillips, copyright, 1925, 1940, by Harcourt, Brace and Company, Inc. 
power. The significance of hydroelectric power to the region is even greater than these figures indicate because of the close integration of power with agriculture and industry. A visual impression of the importance of power and irrigation to the West may be gained from Map 6. This is the most significant map of the several included in these pages and it deserves careful scrutiny.

The physical features of the Mountain West are a major determinant of the character of the region's mining industry. The geologic forces which created the mountains, also produced veins and lodes of the various metals. The formation of the rugged, broken terrane of the mountains frequently served to bring such veins to the surface. Erosion is another very important geologic force which helps to make ore deposits visible. In the case of gold, erosion created the placer deposits in streams and it was among these deposits that the first discoveries of the mineral wealth of the West took place.

A somewhat different set of geologic forces lead to the creation of coal, petroleum, potash, and phosphates. These forces also were active in the Mountain West, leaving large deposits of minerals for discovery and exploitation by man. Up to the present time, however, the West's mining industry has been based primarily on the metals. As Map 7 shows, the Mountain West produces about 93 per cent of our total annual supply of domestic copper, 68 per cent of our tungsten, 48 per cent of our lead, and 33 per cent of our zinc. It also produces nearly all of our molybdenum and most of our potash.

An attempt to assess the significance of the mining industry of the Mountain West reveals some interesting contradictions. Western mining produces only about 10 per cent of the nation's output of all minerals, and at first glance mining in the West easily might be classed as of secondary importance. Yet as the figures cited immediately above reveal, 


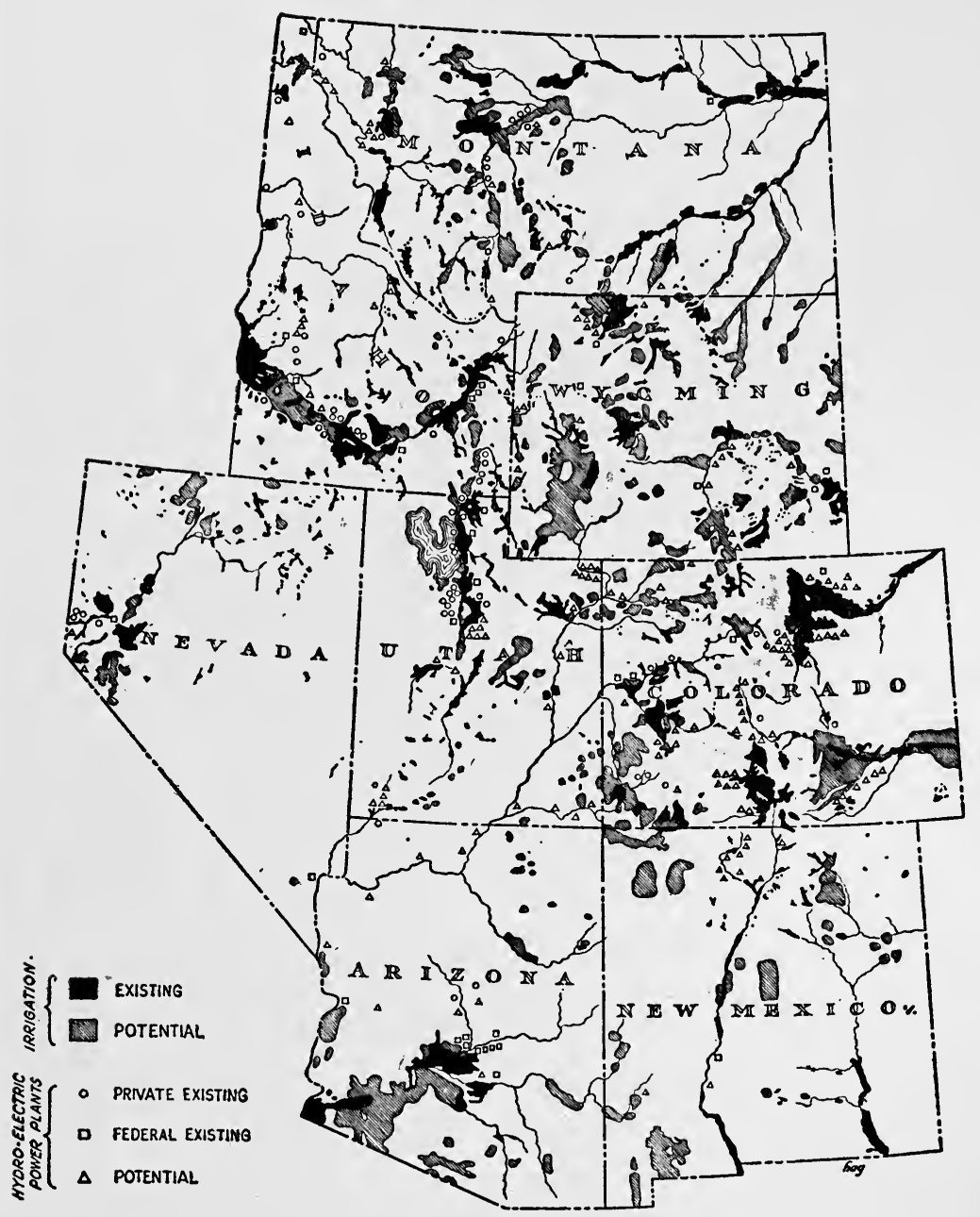

MAP 6

Irrigation and Power in the Mountain West

Complied from National Resources Board: Report, December 1, 1934 (Washington D. C., United States Government Printing Office, 1934); National Resources Planning Board: The Pecos River Joint Investigation (Washington, D. C., United States Government Printing Office, 1942); United States Department of the Interior, Bureau of Reclamation: The Colorado River (Washington, D. C., March, 1946); and United States Senate Document No. 191, 78 Congress, 2 Session: Missouri River Basin (Report by the Secretary of the Interior on the Bureau of Reclamation's plan for basin development; Washington, D. C., United States Government Printing Office, 1944). 

the domestic supplies of many of the metals essential to our economy are found almost entirely in the Mountain West. Within the region equally striking contradictions may be found. The spectacular historical origins of mining in the West continue to influence the general attitude which pre-

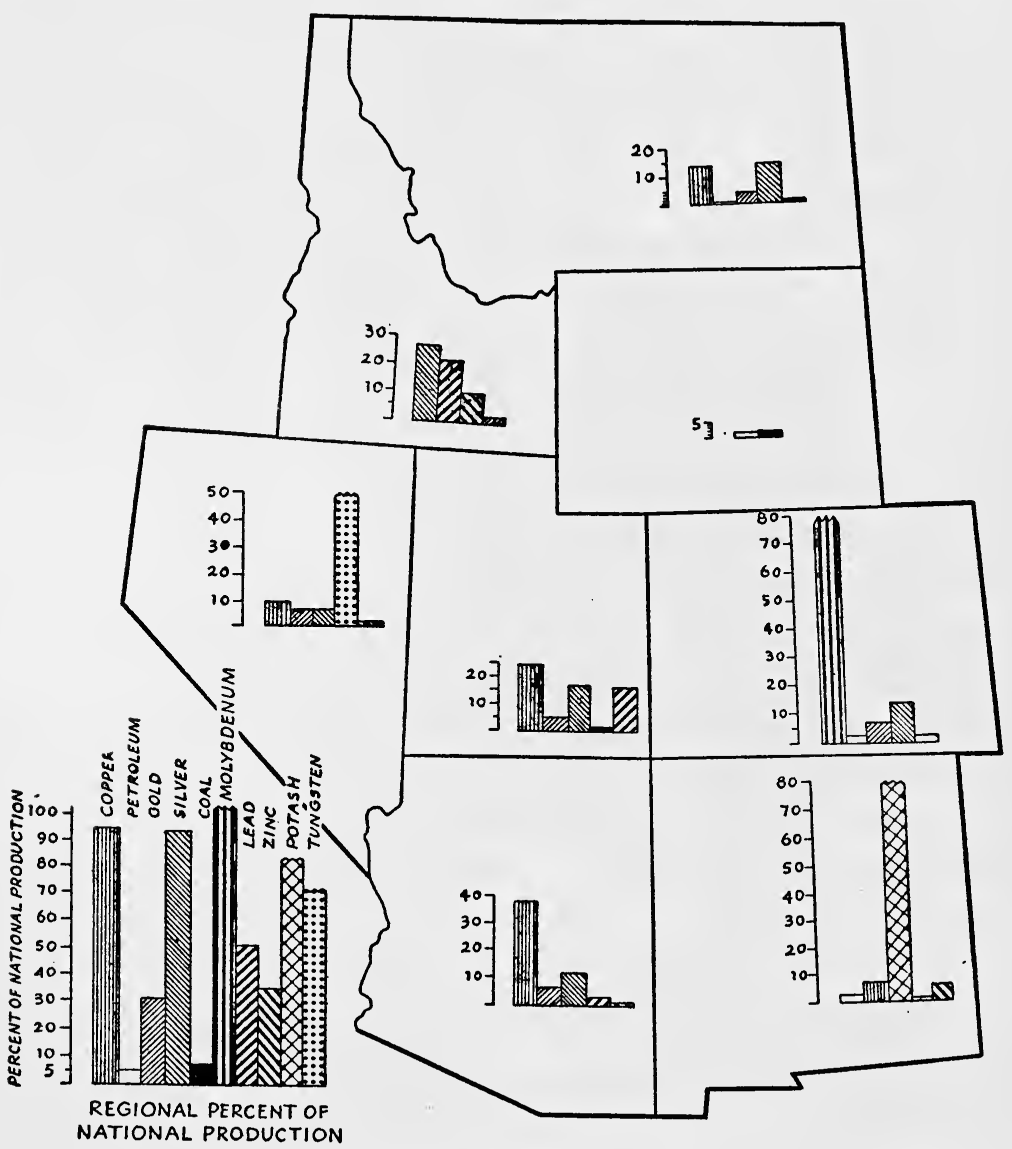

MAP 7

Value of Principal Minerals Produced in the Mountain West1939. Shown as Percentages of National Production

SourcE: United States Department of the Interior, Bureau of Mines: Minerals Yearbook, $194^{\circ}$ (Washington, D. C., United States Printing Office, 1940). 
vails today toward the industry. Accordingly, the Mountain West regards its mining industry as of first-rate importance. This attitude is reflected in many ways, but probably with most striking effect in the political influence of mining interests in state legislatures and with our Congressional delegates. ${ }^{3}$ Yet the fact is that from the point of view of the regional economy, mining is not nearly so important as it might appear. In terms of value of product it ranks second to agriculture in importance. In addition, the contribution of mining to regional income is substantially reduced by the fact that much of the return to mining enterprises accrues to absentee stockholders and managers (See Chapter 12). In terms of employment mining is not a major source of employment in the region, being surpassed in importance by four other major industry groups. In 1940 total employment in mining was less than 80 thousand. In the same year agriculture employed 331 thousand, or nearly one-third of all those employed in the region. Mining and minerals are important in the regional economy and they will continue to be so. Nevertheless, their relative importance should not be exaggerated.

\section{Cultural Characteristics of the Mountain West}

The culture of the Mountain West is not nearly so homogeneous as the physical base. It has been pointed out that "the South" is a region mainly because it possesses a

${ }^{3}$ For example, consider the following: After an account of the legislative history of successful attempts of the mining industry to avoid taxation of its properties in Colorado, and after evaluating the various arguments for and against the taxation of mines, Professor Earl Crockett concludes, "Obviously, judged on the basis of value of annual output Colorado mines, as a group, were not paying property taxes in proportion to those paid by agriculture. In order for the same proportion to prevail, assuming farm taxes remained constant, mines would have had to pay at least $\$ 2,706,000$ in property taxes. Whereas actually in 1944 they paid about $\$ 1,657,000$, or an estimated \$1,049,0oo less." -Earl C. Crockett: "Should Colorado Adopt A Severance Tax?" Taxation in Colorado. Report No. 2 (University of Colorado, Boulder, Colo., November, 1946), p. 22. 
homogeneous culture, which is superimposed upon a diverse physical region. ${ }^{4}$ The reverse might almost be said about the Mountain West. ${ }^{5}$ The modern West is a product of three diverse cultures-the Indian, the Spanish, and the AngloAmerican. Most of the population is derived from white emigrants from the East, but the older native minority populations still flourish. The cultures of the Pueblo and the Navaho are alive and vigorous in the Southwest, while other Indian civilizations also exist in the north. The Spanish influence is still strong at least as far north as Denver. In rural areas it penetrates all the way to Montana. The peoples of Spanish or Mexican origin constitute the West's largest minority group, but the Japanese-American group also is numerically significant. Most of the national problems of minority relationships are present in this particular region.

Another unique and vital culture in the West is that which has grown up around the Mormon Church. This culture is centered in Utah, but it reaches far beyond the borders of the one state. The Mormon culture has made a magnificent positive contribution to the life of the Mountain West. Its emphasis upon conservation and husbandry is of particular importance in the economic sphere. ${ }^{6}$

The cultural background of the present-day West has been colored also by the historical events which led to its settlement by the Euro-Americans from the East. The prospector-miner, the cattlemen and sheepmen, and the pioneer settler, working together and in competition with each other, have created a historical and cultural background which clearly distinguishes the region from other parts of the United States.

4 See Carle C. Zimmerman: Outline of American Regional Sociology (Mimeographed; Cambridge, Mass., Phillips Book Store, 1947).

5 Ladd Haystead: If the Prospect Pleases: The West the Guidebooks Never Mention (Norman, Oklahoma, University of Oklahoma Press, 1945). tionalism.

6 The author speaks from a background of New England Congrega- 
This is a living, vital culture. It permeates the language with scores of colorful colloquialisms. The dress of the cowboy, and even of the hard-rock miner, which originated in the special requirements of the occupation, affect Western living. The early ranch house has influenced modern Western architecture just as clearly as has the Spanish adobe. The varied aspects of Western culture have been dramatized for the benefit of the native and the tourist in the ubiquitous rodeo, the revival of ghost-towns like Central City, and even in the wide-open gambling of Reno and Butte.

\section{The Habit of Exploitation}

The economics of enterprise may lead the Westerner to stage rodeos and display Indian silver crafts in order to attract tourist dollars, but this is by no means the most important impact of Western culture upon the contemporary economic life of the region. Of much greater importance is the cultural inheritance of the attitude which regards natural wealth as the legitimate object of reckless exploitation.

James Bryce, who surveyed the American democracy a half-century ago noted in his trip to the Mountain West in 1887 that "These people are intoxicated with the majestic scale of the nature in which their lot is cast, enormous mineral deposits, boundless prairies, forests which, even squandered-wickedly squandered-as they are now, will supply timber for the United States for centuries." " Although Bryce accurately described a fundamental characteristic of the Western pioneer, he underestimated the seriousness of the rapid drain upon our forest resources, for within twenty years of his visit to the West forest depletion had become so extravagant that Gifford Pinchot and Theodore Roosevelt were

${ }^{7}$ James Bryce: The American Commonwealth, (New York, The Macmillan Company, 1921), Book II, p. 895 . 
able to launch the conservation movement and reserve large tracts of the Western forests for future use.

The destruction of timber lands was indeed spectacular. In the more heavily forested areas of the country no log was acceptable for use unless the smaller end was sixteen inches in diameter. Only the best timber was put to use, the remainder being burned. ${ }^{8}$ Indeed it is more than probable that fire destroyed much more timber than was utilized in early days. Even now there are large burnt-out areas visible in many parts of the West where the forests were killed by fires started by careless settlers half a century ago. And one of the chief causes of the mud avalanches which threatened to destroy the fertile Salt Lake Valley in the 1920's was a series of fires which ravaged the slopes of the Wasatch Mountains which form the watershed of the valley.

The extermination of the buffalo is one of the best known examples of the wanton destruction and exploitation practiced by the early Westerners. The buffalo was a useful animal to the pioneers. Thousands of whites and Indians alike depended upon the animal for their meat supply. Buffalo chips were almost the only fuel on the plains. The buffalo's hide was used for clothing, bedding, shoes, and blankets. Yet the animal was virtually exterminated in a short period of time. It has been estimated that in primitive times there were 55 million buffalo in the United States. By 1800 , this number had been reduced to 40 million. In the next 50 years this was reduced to 20 million. ${ }^{9}$ The buffalo herd would huddle stupidly together when attacked by hunters and allow themselves to be killed rather than run away. Frontiersmen have told stories of killing as many as 120 animals in a single stand of 40 minutes. John R. Cook relates

8 Everett Dick: Vanguards of the Frontier (New York, D. AppletonCentury, 1941), p. $5^{13}$.

'Ernest T. Seton: “The American Bison or Buffalo," Scribners Magazine, Vol. 40, p. 402. 
how he killed 88 and wounded many more in even less time. ${ }^{10}$ This was both a lucrative financial enterprise and an engaging sport for the pioneers. Buffalo skins were highly prized in the East and the bones were used commercially also. Most of the meat was allowed to go to waste. It is estimated that not $1 / 10$ of the meat was used. The Hemtsman Echo, a newspaper published in Nebraska in the 1860 's, reported that the slaughtered carcasses lay so thickly along the road that the stench was fearful. ${ }^{11}$

The pioneer was equally wasteful of the soil. Although crop rotation and allowing a field to lie fallow are ancient devices to protect soil fertility, they were not widely used in the West. Fields were sowed every year. ${ }^{12}$ Early irrigation practices were extremely crude, and erosion and leaching of the soil were commonplace.

The attitudes of the pioneer settler which gave rise to wasteful practices is well summarized by the Western historian, Everett Dick:

"The spirit of conquest or exploitation ran strong in the veins of the vanguards of white settlement. The resources of the country were so vast that there was no thought or care whether they would ever be exhausted. These natural resources belonged to the government, and the first whites argued that they were doing the government a favor to exploit them. There was no hesitation to use the government grassland for cattle ranches, to cut the forests in logging, to dig the lead or gold, or wantonly destroy the multitudes of wild game. This ruthless exploitation was accompanied by the greatest waste." 13

These attitudes of the past are still influential in the Mountain West of today. They form a part of our cultural ${ }^{10} \mathrm{John}$ R. Cook: The Border and the Buffalo (Topeka, Kansas, 1907), pp. $164-67$.

11 Everett Dick: Vanguards of the Frontier, op. cit., p. 430.

12 Edward C. Kirkland: A History of American Economic Life (New York, Crofts, 1939), p. 155 .

13 Everett Dick: Vanguards of the Frontier, op. cit., p. $5^{13}$. 
heritage, inspiring and strengthening the continued attack on federal regulation and control of forests and grazing lands. They seduce the Westerner to tolerate and invite exploitation of Western resources by absentee corporations. There are many present-day Westerners who would see nothing objectionable in the remark of a New York oil company vicepresident who, when being urged to build an oil-shale processing plant at Rifle, Colorado, responded, "If you can lower the costs sufficiently, we'll be glad to build the camp."

It would never occur to him, or to the Westerner of like mind, that the Mountain West of today is no longer interested in mining camps which become ghost towns tomorrow when the resources have been stripped away. This is the attitude which the modern advocate of conservation and orderly development of resources must combat if the Mountain West is to achieve a stable, balanced economy. 
Chapter $\begin{aligned} & \text { A. Brief Inventory of Resources- } \\ & \text { Utilized and Un-Utilized }\end{aligned}$

In the preceding chapters frequent references have been made to the rich natural resources of the Mountain West, and it has been pointed out that many of these resources are underutilized or scarcely utilized at all. A more systematic review of the facts about the West's resources will provide a clearer appreciation of the extent of the region's actual contribution to the national economy and its potential future contribution.

\section{Minerals}

At the present time the mineral wealth of the Mountain West is in some ways the most important resource of the region. The national production of copper, molybdenum, lead, zinc, tungsten and vanadium is concentrated in the Mountain West, and $5^{\circ}$ to $9^{\circ}$ per cent of the reserves of these metals lie within the region ${ }^{1}$ (See Table 2). All of our known economic deposits of uranium are found in the West and at present the Atomic Energy Commission is promoting an ex-

1 United States Bureau of Mines and Geological Survey: "Mineral Position of the United States" in United States Senate Committee on Public Lands, Investigation of Natural Resources. Hearings before a Subcommittee of the Committee on Public Lands. 8o Congress, I Session (Washington, D. C., United States Government Printing Office, 1947), pp. 165-338. 
TABLE 2: National Mineral Supply-Production and Reserves Accounted for by the Mountain West.

\begin{tabular}{|c|c|c|c|}
\hline \multirow{2}{*}{ MINERAL } & \multirow{2}{*}{$\begin{array}{c}\text { Percentage of } \\
\text { National } \\
\text { Output Pro- } \\
\text { duced in } \\
\text { Mountain } \\
\text { West (r 944) }\end{array}$} & \multicolumn{2}{|c|}{ RESERVES } \\
\hline & & $\begin{array}{l}\text { National } \\
\text { in Years }\end{array}$ & $\begin{array}{l}\text { Regional } \\
\text { in Years }\end{array}$ \\
\hline \multicolumn{4}{|l|}{ Fuels } \\
\hline Petroleum & 5 & 14 & 0.8 \\
\hline Coal & 5 & 4,235 & $\mathrm{I}, 780$ \\
\hline Oil-Shale ${ }^{3}$ & $\begin{array}{l}\text { No Pro- } \\
\text { duction }\end{array}$ & IOO & IOO \\
\hline \multicolumn{4}{|l|}{ METALS } \\
\hline Copper & 89 & 25 & 20 \\
\hline Molybdenum & $9^{\circ}$ & 99 & 97 \\
\hline Lead & $5^{0}$ & I 5 & $\begin{array}{c}\text { (Major Per- } \\
\text { centage) }\end{array}$ \\
\hline Zinc & 88 & 24 & \\
\hline Tungsten & 68 & 5 & 2.5 \\
\hline Vanadium & 95 & 13 & 12 \\
\hline Uranium & n.a. & n.a. & $\begin{array}{c}\text { (Major Per- } \\
\text { centage) }\end{array}$ \\
\hline Silver & 93 & 13 & 12 \\
\hline Gold & 75 & 19 & 6 \\
\hline \multicolumn{4}{|l|}{ FERTILIZERS } \\
\hline Potash & 83 & I 13 & 98 \\
\hline Phosphate & 6 & 470 & $3^{8} 5$ \\
\hline
\end{tabular}
et passim.

${ }^{1}$ In terms of average production, 1935-1944.-Ibid., p. 179, Figure 2,

2 Minerals Year Book, 1945 , U. S. Bureau of Mines.

${ }^{3}$ Carl Belser: Oil-Shale Resources of Colorado, Utah, and Wyoming. (Mimeographed) Paper presented at the annual meeting of the Petroleum Section of the American Institute of Mining and Metallurgical Engineers, Denver, Colo., September 29 through October 1, 1947, and published by permission of the United States Bureau of Mines. 
tensive search for new sources of the fissionable material within the region.

Nevertheless, the great un-utilized potential mineral wealth of the Mountain West is to be found, not in the metals, but in fuels and fertilizers-coal, oil-shale, potash, and phosphate. Large portions of the nation's reserves of these vital minerals are here; yet present production is a small fraction of national output for all of them except potash. It is difficult to grasp the full significance of the tremendous potential for food and energy production which the minerals of the West hold. Its potash and phosphates are destined to enrich millions of acres of farm land. Its coal reserves are sufficient to last a thousand years.

Most spectacular of all, perhaps, is the future of the oilshale industry of the West. Today a small pilot plant operated by the Bureau of Mines is the sole producer of oil from shale. Within twenty years there are likely to be as many as fifteen or twenty plants in operation producing up to two million barrels of oil per day from shale-approximately one-third of our present daily consumption. Such an industry would create whole cities where today there is only desert, and would add at least a half million persons to the population of the region. The total investment required for the creation of the industry and of the cities and towns which would grow up around it would amount to nearly four and one-half billion dollars. The oil-shale industry, alone, is capable of bringing an industrial revolution to the undeveloped West.

\section{Forests}

The forests of the Mountain West are of primary importance as watersheds, grazing areas, and places for recreation. They are of secondary importance as producers of lum- 
ber. The Mountain West has about 10 per cent of our total stand of timber and $171 / 2$ per cent of our saw timber. The annual drain of saw timber from the region is approximately two and one-fourth billion board feet, which is about 11.5 per cent of the national drain.

The prospects for the future are that the Mountain West will be called upon to increase its production of timber in order partially to offset the decline in production in other areas. According to Forest Service estimates:

"In the North Rocky Mountains, access roads and utilization of the less favored species may increase drain almost 1 billion board feet annually for 30 to 40 years. But after that, output would need to taper off again to somewhere near the 1944 level, which is about as high as it is reasonable to set the regional growth goal. Similarly, if economic conditions permit, the output of the South Rocky Mountains region could theoretically be doubled. But that would represent a gain of only $1 / 2$ billion board feet." ${ }^{2}$

The Mountain West shares with the rest of the nation a prospect of declining timber resources unless a substantial program of forest growth is undertaken. At present the growing timber stock of the region is 21 per cent less than the stock required by a program adequate to supply our future estimated needs for timber. This figure happens to be exactly equal to the national average. ${ }^{3}$

Thus we have a regional situation in which present timber resources are not being utilized to their full capacity. As timber supplies decline elsewhere it is certain that there will be a substantial increase in the regional saw-timber drain. However, such an increase must be accompanied by a significant addition to the growing stock if the timber resources of the region are to be maintained. Add to these facts the pres-

2 United States Department of Agriculture, Forest Service: Gaging the Timber Resource of the United States (Washington, D. C., December, 1946), p. 42.

3 Ibid., Table 7 , p. 16. 
ence in many places of erosion and overgrazing, and one begins to see the great importance of forest conservation in any program for the economic development of the Mountain West.

\section{Recreation}

It is difficult to estimate the relative degree of utilization or underutilization of the recreation resources of the West. From one point of view it is possible to say that the resources are unlimited and scarcely utilized because of the tremendous area and variety of scenic beauty and the climate advantages which permit all-year-round recreational activity. Nevertheless, the natural facilities must be supplemented by capital investment in transportation, hotels, parks, dude ranches, and places of entertainment. Such facilities have been expanding rapidly under the stimulus of post-war prosperity. In 1948 there was overcrowding in several of the national parks. In that year the parks and monuments of the region received 5.3 million visitors out of a total of 16.4 million visitors to all national parks and monuments in the United States. This is about one-third of all such visitors-a high proportion in view of the distance of the region from the population centers of the country.

In 1949 the Rocky Mountain National Park reported an increase of more than 10 per cent over 1948, and Yellowstone National Park reported an even greater increase. The number of such visitors might well continue to increase during the next decade if we have a high-level production economy. With proper facilities for handling automobile traffic and the requirements of visitors for food and lodging the national parks and private resorts of the region could accommodate many more than five million persons without overcrowd- 
ing and the consequent deterioration of the aesthetic values of the region."

\section{Agricultural Land}

The problem of land utilization is so complex that it is very difficult to judge whether the land resources of an area are underutilized at a particular time. Climatic conditions, circumstances of demand, the state of technical advance, and other factors influence land use. In general, farmers attempt to make allowance for such factors and to use their land most effectively in view of the particular combination of circumstances of the moment.

It is possible to make a few generalizations about the West which are based on the peculiar characteristics of the soil and climate of the region. The bar chart shown immediately below reveals the striking characteristics of Western land use.

(Irrigated Land 11.8)

(Harvested Acreage 23.1)

(Land Available for Crops 44.1)

(Pasture in Farms 209.6)

(Land in Farms 244.6)

(Total Land Area 549)

[MILLIONS OF ACRES]

Source: Agricultural Census of 1945-data for 1939 and 1944

4 In some cases it would be desirable to enlarge the boundaries of certain parks and monuments in order to accommodate larger numbers without overcrowding. The total of such additions for the United States would approximate three million acres according to America's Needs and Resources. -Dewhurst, op. cit., p. $54^{2}$. 
To begin with, farms comprise about 45 per cent of the total land area, ${ }^{5}$ while in the central regions of the United States as much as $9^{\circ}$ per cent of the land area is in farms. Of the 245 million acres in farms in the West, 207.6 million acres are in pasture land, and only 44 million acres of land are available for crops. In this respect the West is unique in the United States, the percentage of land available for crops being very much below the percentage available in any other region except the Pacific.

On the average, the harvested acreage in the Mountain West is less than $5^{\circ}$ per cent of the land available for crops. Other regions of the United States are similar, particularly the Pacific Coast region. In the West the semi-arid climate requires a greater use of fallow land on dry-land farms, and the lack of rainfall and the emphasis on livestock in agriculture make it advantageous to retain plowable pasture as pasture rather than attempting to use it for field crops. Irrigated land represents slightly more than half of harvested acreage, but much of the crop value of the region is concentrated on the irrigated land.

Potential future development of agriculture in the West depends mainly on an increase in the irrigated area. The pasture and grazing land of the region is now utilized at its maximum capacity. Some state-owned land might be brought into cultivation, but no programs for this purpose exist at present. It is possible that as much as five or six million additional acres could be irrigated eventually. Perhaps not more than three or four million acres will be irrigated under programs envisaged at the present time. This figure represents the major possibility for greater land utilization in the West. However, it was pointed out in Chapter 4 that, because of the high productivity and the kinds of crops grown, an inper cent in New Mexico.

${ }^{5}$ By states the percentage ranges from 9 per cent in Nevada to 64 
crease in the irrigated area under cultivation in the West would be of great importance both to the region and to the national economy.

\section{Water and Power}

The full utilization of the water resources of the Mountain West will require the creation of an integrated program of flood control, irrigation, and hydroelectric power development. Such a program will involve the construction of many additional dams and storage reservoirs. If this program is based on the goal of full utilization of water and power resources now potentially available, it will be possible to increase the hydroelectric generating capacity of the region to an eventual 14.5 million kilowatts of installed capacity. The present installed capacity is slightly over 2 million kilowatts. The Mountain West possesses 25 per cent of the nation's hydro potential which is the greatest potentiality for hydroelectric power in the United States outside of the Pacific Coast region. Yet, on a relative basis the development of hydroelectric power in the region has lagged behind the nation's progress. Within the region some $13^{-14}$ per cent of the potential has been harnessed for production, while for the nation as a whole about 25 per cent of the potential is now in use.

The full utilization of hydroelectric power and water resources of the region is the basic requirement for the development of a high-level production economy in the Mountain West. 


\section{Atomic Energy in the Mountain West}

The emphasis throughout this book on the desirability of developing the hydroelectric power potential of the Mountain West raises the question of the present and future role of atomic energy in the region. Although a number of technical problems remain to be solved, it now seems fairly certain that nuclear fission will not supplant coal and water as sources of electric energy, but rather complement these more orthodox sources. According to Mr. David Lilienthal, "there is not any reason to expect that an atomic energy industry will spring into being overnight and make its appearance as a colossus upon the national scene, displacing at once the power industries which now serve us and disrupting in a few years the whole pattern of our economy. It will almost certainly follow the course of supplementing rather than supplanting existing economical sources of energy supply. Our judgment is that clearly no one should delay sound and economical additions to power supply, whether by fuel-generated electricity or water power, because somewhere in the future atomic energy will come on the scene as an additional source of supply." 6

It seems safe to say that an area possessing such abundant supplies of coal and falling water as the Mountain West will not need to use scarce uranium or plutonium as an energy source. In fact the immediate situation is just the reverse, for in April 1949 the Atomic Energy Commission announced plans for a half-billion-dollar atomic energy experimental plant near Arco, Idaho. One of the important reasons for choosing this site was the availability of electric power from hydroelectric plants on the Snake River. The size of this installation overshadows the economic significance to the re-

${ }^{6}$ David E. Lilienthal: Atomic Energy and American Industry. (Remarks before the Economic Club of Detroit; mimeographed; Washington, D. C., Atomic Energy Commission, October 6, 1947). 
gion of the development of regional sources of uranium ores, mentioned earlier in this chapter.

It is interesting to notice in passing that two of the three major operating installations of the Atomic Energy Commission are in the West (Hanford, Washington, and Arco) while the third is in the South at Oak Ridge. All three have been located in nonindustrialized, peripheral regions of the nation, close to large supplies of hydroelectric power. 
Part Three $\mid \begin{aligned} & \text { тна } \\ & \text { economic } \\ & \text { ваse }\end{aligned}$ 



\section{Chapter 7. Population}

First the land and then the people. The economic activity of any group is closely related to the physical resources at its disposal. At the same time the composition of the group itself-the human resources of the economy-influences economic activity. Consequently, the next step in the description and analysis of the economy of the Mountain West is to study the human resources of the region. In this chapter and the next the population will be described, and the labor force and employment pattern of the region will be analyzed. It will then be possible (in Chapter 9) to consider the nature of the system of production which emerges from the interaction of the physical and human resources of the region.

\section{Density and Geographic Distribution of the Population}

To understand the reservoir from which the economically productive labor of the region is drawn, it is important to analyze the character of the population and the changes which take place in it through migration. The population 
also provides the regional market for goods and services so that eventually an analysis of the consumption habits and purchasing power of the population will be in order.

Among the purely demographic features of the population there are two in which a distinctive regional feature can be seen most clearly. These are the density of the population and its geographic distribution over the land area of the region.

The Mountain West has an area of $86_{3}, 887$ square miles, which is nearly one-third of the United States, and a population of $41 / 2$ millions which is only about 3.15 per cent of the total population. The density of the population is 4.8 per square mile as compared with 44.2 for the United States. A few additional comparisons by regions and states are of interest:

$\begin{array}{lc}\begin{array}{l}\text { Census Division } \\ \text { or State }\end{array} & \begin{array}{c}\text { Population } \\ \text { Per Square Mile }{ }^{1}\end{array} \\ \text { Middle Atlantic } & 274.0 \\ \text { New England } & \text { I } 33.5 \\ \text { United States } & 44.2 \\ \text { West North Central } & 26.5 \\ \text { Mountain } & 4.8 \\ \text { Montana } & 3.8 \\ \text { Idaho } & 6.2 \\ \text { Wyoming } & 2.6 \\ \text { Colorado } & 10.8 \\ \text { New Mexico } & 4.4 \\ \text { Arizona } & 4.4 \\ \text { Utah } & 6.7 \\ \text { Nevada } & 1.0 \\ \text { Rhode Island } & 674.2 \\ \text { Massachusetts } & 545.9 \\ \text { New York } & 281.2\end{array}$

${ }^{1}$ United States Bureau of the Census: Statistical Abstract of the United States: 1946 (Washington, D. C., United States Government Printing Office, 1947), pp. 3 and 5 . 
Only one or two states outside the region have a density of population less than that of Colorado, but none less than any of the other seven states. This sparseness of population is one of the homogeneous elements which makes the Mountain West a distinct region.

Equally striking is the distribution of the population over the land area of the region. The nature of this distribution is clearly shown in Map 8. As might be expected, the population of the region is concentrated in the fertile valleys along the rivers of the West and against the barriers of high mountain ranges. The map shows the effect of rivers on the location of population quite clearly. Concentrations are particularly heavy along the Snake River in Idaho, the Rio Grande in New Mexico, the Gila in Arizona, and the Arkansas and South Platte in Colorado. The only exception is the Colorado River, which flows through deep canyons in Utah and Arizona (Grand Canyon).

The map does not show the influence of mountains on population location so effectively; since only the Continental Divide is indicated. A glance once more at the relief map of the region (Map 1) will reveal the problem which would have faced the cartographer had he attempted to draw in even those mountain ranges significant in the location of population. ${ }^{2}$ Nevertheless, the mountain influence is visible in Colorado, where two-thirds of the population of the state is to be found within fifteen miles of the Front Range of the Rockies. Most of the population of Utah also is concentrated at the western base of the Wasatch Mountains with the Great Salt Lake Desert forming the western boundary of the central valley of Utah. Western Montana and northern Idaho are

2 The Front Range is not shown. Many of the cities in Colorado lie directly against this range. For example, there is Colorado Springs with Pikes Peak rising immediately to the west of that city (the middle one of the three large, black areas). 


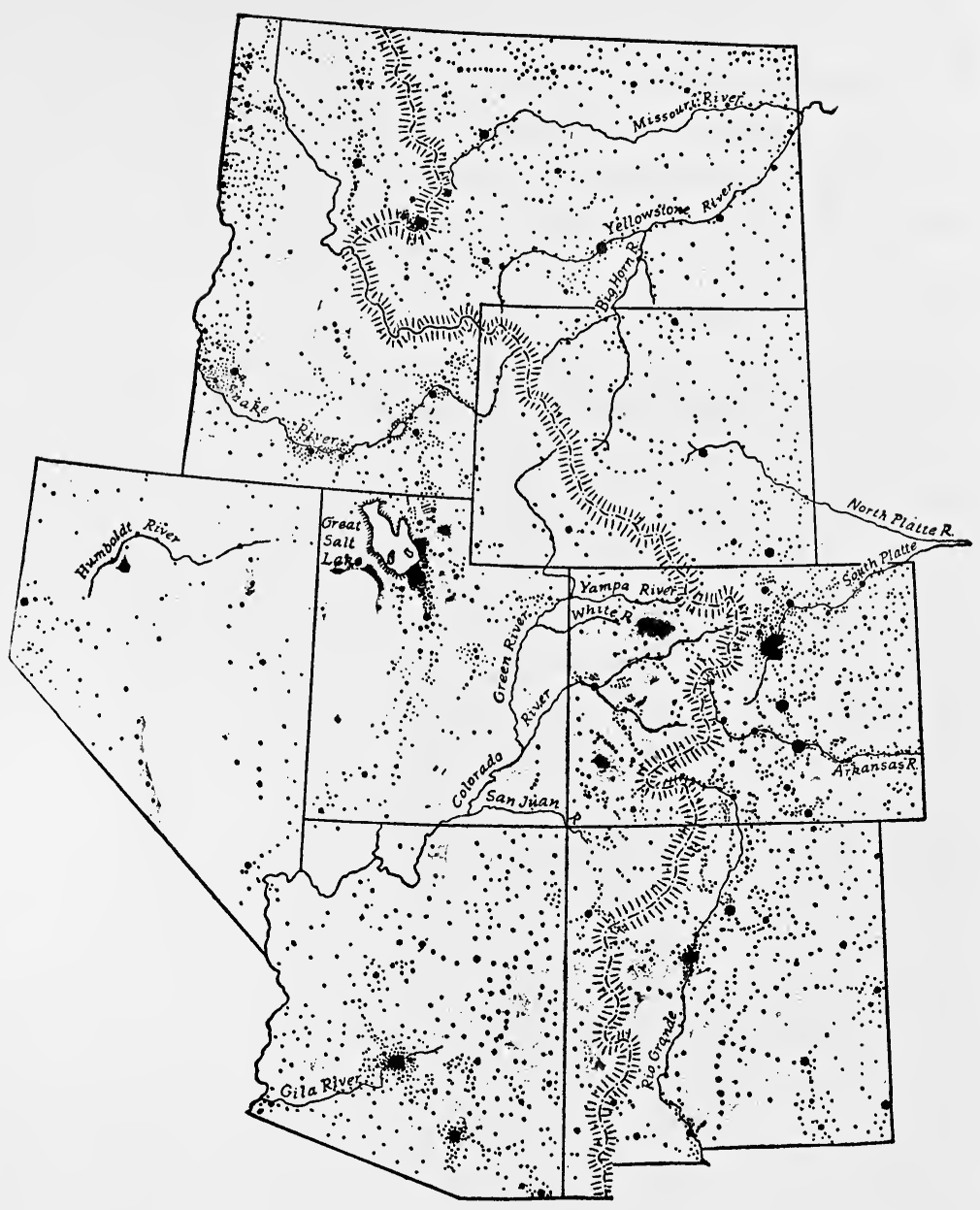

MAP 8

(Scale 1 dot $=500$ persons)

Geographic Distribution of the Population of the Mountain West 1940

Source: United States Bureau of the Census: Population. Vol. I, Number of Inhabitants. 16th Census of the United States: 1940 (Washington, D. C., United States Government Printing Office, 1942); United States Bureau of the Census: Population, Unincorporated Communities: United States by States. 16th Census of the United States: 1940 (Washington, D. C., United States Government Printing Office, 1943); and Rand McNally Road Atlas of the United States, Canada, and Mexico (New York, Rand McNally and Company, 1941). 
additional examples of areas in which the location of population is oriented toward the mountain ranges.

Throughout the region there are scattered minor centers of population whose locations are determined by particular natural resource sites, other than water and irrigation. In southeast New Mexico, for example, oil fields are found around Hobbs on the Texas border, and a recreation area is located at Carlsbad. Tuscon, Arizona, southeast of Phoenix, is a desert oasis and resort town. Butte, Montana, in a bend of the Continental Divide, is the foremost example of a mining area concentration of population, although similar ones are found in every state of the region. The larger dot in eastern Nevada is the copper mining center of Ely.

Map 8 also illustrates the importance of the cities of the Mountain West in the economy and culture of the region. None of the cities or metropolitan areas shown on the map is large by national standards. The largest, Metropolitan Denver, is less than a half-million in population, in a state of 1,123,000. A glance at the map will show that every state is dominated by its cities: Albuquerque and Santa Fe in New Mexico; Tucson and Phoenix in Arizona; Pueblo, Colorado Springs, and Denver in Colorado; Cheyenne, Laramie, and Casper in Wyoming; Billings, Butte, and Helena in Montana; Idaho Falls, Pocatello, and Boise in Idaho; Provo, Salt Lake City, and Ogden in Utah; and in Nevada, Reno with a population of nearly 25,000 in a state of only 110,000 inhabitants. There is a real and significant meaning behind the apparent boastfulness of Reno's self-designation as "The Biggest Little City in the World."

The location characteristics of the population of the Mountain West are a very important factor in the homogeneity of the region. The close relation of population concentration to physical resources is striking. If we add the semi-physical factor of transportation routes and facilities, 
the relationship becomes even closer particularly in regard to such cities as Denver, Cheyenne, Salt Lake City, and Phoenix. There is also a distinctly noticeable tendency for the population of the region to concentrate toward the interior of the region and away from its peripheries. A similar tendency is noticeable in the areas adjacent to the region on either side. The Great Plains have a relatively sparse population, and to the west the population of the Pacific Coast is concentrated between the Sierras and the sea. Thus, the Mountain West stands, to a large extent, as an independent regional entity distinct from its neighbors to the east and to the west.

\section{Race, Age, and Sex}

The population of the Mountain West is predominantly a native-born, white population, younger than the national average, and with a relatively high proportion of males to females.

The median age of the population of the Mountain West is 26.8 years as compared with 29.0 for the United States as a whole. This regional median stands just about midway between the lower median age found in the South (24-25), and the higher age concentration in New England and the Pacific Coast (31-33). The low median age in the Mountain West is due mainly to a relatively high regional birthrate, particularly in New Mexico, Utah, and Idaho. In addition, the West has not experienced an out-migration comparable to that of New England, nor an immigration of persons of retirement age comparable to that of the Pacific States.

Immigration to the Mountain States has taken place 
primarily among the younger males, and this has influenced not only the age composition of the population but its sex composition as well. A few comparisons of the number of males per 100 females in the region and in the United States will suffice to show that the Mountain West possesses the relative preponderance of males characteristic of a "new" country. Tables 16 and 17 at the end of the volume show that the sex ratio in the Mountain West is considerably above the national ratio for the total population-105 as compared with 100.7. The discrepancy is even somewhat larger for native-born whites-105.9 to 100.1 . In both of these categories the Mountain West has the greatest preponderance of males of any region of the United States. The number of foreign-born white males in the West exceeds the foreignborn white females in the ratio of 130 males for each 100 females. This ratio may be compared with the ratio of 111.1 for the same population category for the country as a whole. Only one census division has a higher ratio in the foreignborn group than the Mountain States, but no state even approaches the ratio of nearly 2 to 1 found in Nevada. It would seem that there might be reason for some modern counterpart of Horace Greeley to exclaim "Go West, Young Woman, go West!" 3

The age and sex characteristics of a population are not without economic interest, but they probably have less effect on the over-all nature of the economy than the social or cultural divisions of the population. ${ }^{4}$ According to the Census of 1940, 93.5 per cent of the population of the Mountain West was native-born and 95.9 per cent was white. When

${ }^{3}$ Unfortunately the preponderance of males is not accompanied by an equal preponderance of unmarried males. In the Mountain West 33.7 per cent of the males over 15 years of age are single, as compared with 33.2 per cent for the nation. (In Montana the percentage of single males is 38.0 ). ter 8$)$.

${ }^{4}$ Age and sex do influence the size of the labor force (See Chap- 
compared with the nation as a whole this predominance of native, white stock is brought out even more sharply. In the United States the foreign-born population represents 9.66 per cent of the native population; in this region the relationship is 6.9 per cent. In the United States the foreign-born white population is 10.69 per cent of the native white population; in the region only 6.5 per cent. To put the matter another way, the Mountain West has 3.15 per cent of the nation's total population but 3.37 per cent of its white population.

Nevertheless, the dominant influence of the native white population in the West should not be allowed to obscure the fact that there are regional concentrations of racial groups in the Mountain West and that within the region the minorities do exercise an important economic influence on the economy. Notice, for example, that:

The Mountain West has yet it has only

on the other hand, it has
3.1 5 per cent of our total population; 0.28 " " " " Negro population; 3.64 per cent of the Chinese population;

$$
\begin{aligned}
& 6.75 \text { " " " " Japanese popula- } \\
& 36.53 \text { “ “ “ “ American Indian }
\end{aligned}
$$

and, finally, it has at least 27.36 " “ “ " Spanish-speaking members of our total population.

Of these groups the last two have a definite influence upon the regional economy. The Indians account for no more than 3 per cent of the region's total population, yet their presence constitutes both a regional and a national economic problem. The Spanish-Americans are numerically more important. There are at least 433,000 in this group, which is about 10.5 per cent of the population of the region. These people constitute the largest minority group in the Mountain West. 


\section{Economic Problems of Minorities in the Mountain West}

When looked upon as a whole, the population of the Mountain West seems to exhibit a high degree of homogeneity. The observer who notes that the population of the region is $9^{6}$ per cent white and 94 per cent native-born presumably might be forgiven for ignoring the almost negligible minority of 5 or 6 per cent in his generalizations about the region. However, it would be a mistake to do so.

The peoples of Hispanic culture are white, and most of them are native-born citizens; thus the census categories conceal their presence in the region. This group is numerically significant. According to the Census reports on mother tongues, the Spanish-speaking population of the region accounts for 10.5 per cent of the total population. Most observers estimate that the number of people of Hispanic culture in the region is considerably larger than the Census estimates of 433,000 . Probably there are as many as 600,000 persons in this group in the region. ${ }^{5}$ Moreover, as Appendix Table 18 shows, these people are concentrated in certain well-defined areas. The greatest concentration is in New Mexico, where the Hispanic-Americans comprise 45 per cent of the population and in many respects strongly influence the cultural, political, and economic life of the area.

The problems of these significant cultural groups-Indians and Hispanos-fall into two broad categories. One set of problems arises out of the existence of the indigenous, self-contained, and almost isolated economy under which many of them live. The others are the more common problems of a minority trying to survive in a larger, majoritydominated economic (and social) sphere.

5 The relevant census figure is found in the report on number of population by mother tongue (See Table 18). Competent observers believe, however, that many who belong to the Hispanic culture groups report, or have reported, English as the mother tongue. 
The life of the Indian of the Mountain West is to a very large extent a self-contained, isolated existence. Most of the Indians live on Indian Reservation lands. Here they follow a cultural pattern of living which is centuries old. It is largely a primitive culture, and its description belongs to the anthropologist rather than to the contemporary economist.

In its economic aspects, however, the life and level-ofliving of the Indians are dependent upon the whims of a Congress whose consideration of Indian affairs is inevitably colored by the larger economic and political problems of the moment. On the whole, such consideration has not yielded much for the Indian. His present economic condition is wellsummarized by the Commissioner of Indian Affairs:

"The problem lies in the extreme poverty of the Indians. At the moment, relatively few tribes could, within any brief period of time, be brought to the position where they could assume any appreciable portion of these costs. (The costs of education, medical care, etc., now borne by the federal government). The poverty of the Indian people is largely traceable to the fact that during the $5^{0}$ years preceding 1934 they were induced, often compelled, to dispose of their best lands.

"Between 1887 and 1934, Indian land holdings decreased from 138 million acres to $5^{\circ}$ million acres, and half of this remainder consisted of poor quality land, on which as much as 45 acres was required to feed 1 cow. Half of the 3 million acres classed as cropland is subject to and requires irrigation, but funds have been made available for the development of only 500,000 acres. Moreover, the Indian owners of this land lack experience, equipment, and capital for establishing themselves on farms. For similar reasons they were not prepared to exploit their timber resources. Much of the farming and grazing land was leased out and most of the timber was sold on the stump to non-Indian operators 
and the Indians obtained but a small part of the income which these resources were capable of producing. Except as laborers, the Indians had but a small part in the exploitation of these resources or of the oil and mineral deposits which underlay the land." 6

In 1934 a serious attempt to establish a firm economic base for Indian life began. The results of that effort can best be described by the Commissioner:

"Since 1934 when funds became available from various sources for credit operations, for land acquisition, for the construction of additional irrigation facilities, the development of stock-water facilities, range and forest improvements, roads soil conservation projects, the improvement in the economic condition of many Indians, individually and as tribes, has been remarkable. This progress has demonstrated that wise investment of Federal and tribally owned funds in the development of Indian resources will improve the economic status of the Indians, raise their standards of living, improve their health and bring the population closer to the day when the Federal administration can be terminated and Federal services withdrawn. . .

"The improvements resulting from resource development during the past 12 years were especially notable in the field of agriculture and stock raising. This is not surprising in view of the fact that the Indian population is predominantly rural. The 1940 census returns show that only 9 per cent of all Indians enumerated were living in urban areas. Even though agricultural extension work among Indians was not organized on a professional level until 1930, and although credit for long-term rehabilitation loans was not available until 1935, the number of beef cattle owned by Indians increased from 170,800 head in 1932 to 382,300 in

${ }^{6}$ United States Department of the Interior: Annual Report of the Secretary of the Interior for 1947 (Washington, D. C., United States Government Printing Office, 1947), pp. 346-47. 
1946; dairy cattle during the same period increased from 11,300 to $5^{0,000}$ head. Income from livestock alone during that period increased from less than $\$ 1,300,000$ to more than $\$ 21,000,000$.

"This rate of increase is encouraging to contemplate, but the distance still to be covered is reflected by the following facts: Indians owning beef cattle in 1946 number slightly better than $16,5^{\circ}$, yet the population of the predominantly grazing reservations amounts to 200,000 . Out of $45,000,000$ acres of range land (including some lands classed as forest and woodland) Indians are using only 35,00o,ooo acres. This marginal area, if it could be brought into Indian use, would permit the Indians to increase their livestock holdings by approximately 300,000 head of breeding cows. This stock, on the basis of 60 breeding cows per family, would give an average income of $\$ 1,200$ to 5 ,ooo families.

"A somewhat comparable situation exists with regard to the use of agricultural lands. In 1932 the Indians were reported as using slightly over $5^{\mathrm{OO}, 000}$ acres in the growing of field crops and gardens. This acreage had increased to about 900,000 acres in 1945, but despite this increase, 1,800,000 acres were still leased to non-Indian operators. The value of sales from crop production in 1946 amounted to $\$ 7,688,500$, an average of $\$ 8.5^{\circ}$ per acre. If the same rate of return were realized on the lands in non-Indian use, the Indians would increase their agricultural income by over $\$ 15,000,000$. On the basis of $\$ 1,200$ per family, 12,500 additional families would benefit.

"Similar parallels could very properly be carried out with respect to the use made of, and income derived from the forests and mineral deposits on Indian lands." 7

In the winter of $1947-8$, conditions among the Navahos of New Mexico and Arizona became so critical that a relief ${ }^{7}$ Ibid., pp. 347-8. 
drive was launched in the Western States and the President ordered an investigation of the situation. ${ }^{8}$

In many respects, the Hispanos' economic history is much the same as that of the Indians. Gradually they have lost their land before the encroachments of the "Anglo" immigrant. Yet they have maintained their cultural solidarity, while attempting to support themselves upon a steadily decreasing economic base. Each generation has handed on its land holdings to its numerous progeny so that today the typical holding is no more than 10 acres-much too small even for subsistence farming.

Attempts have been made to improve the conditions of agriculture in the Rio Grande valley by such projects as the Bureau of Reclamation's Rio Grande Conservancy District (1927) which was set up to utilize the irrigation waters created by Elephant Butte Dam. This project added 100,00o acres to the irrigated cropland of the valley, but, in general, the Spanish-speaking people received little benefit from the project. Too often the Hispano farmers found it impossible to use their newly irrigated land profitably. As traditionalists they had difficulty in adapting their farming methods to new conditions. But more important, the Spanish-Americans had neither the cash nor the credit to invest in the farm equipment which high-yield, irrigated agriculture requires. Nor were they able to purchase additional land to consolidate their holdings and increase their farms to economic size. In the end many of them lost their original small tracts because

8 Three Congressional committees visited the Navaho reservation in New Mexico, Arizona, and Utah prior to April 1948. Secretary of the Interior Krug's recommendation, based on the report of a special investigating committee, proposed a ten-year, \$9o million rehabilitation program, \$25 million of which to be devoted to education. Among other purposes to which the proposed funds are to be devoted are the following: $\$ 4.75$ million for health work among the Navahos, \$20 million for roads and trails within the reservation, $\$ 10$ million for soil and water conservation, $\$ 9$ million for the extension of existing irrigation projects, and $\$ 3.5$ million for off-reservation employment opportunity development. 
'of their inability to meet taxes and water assessments on land whose value had been increased by new water supplies. Consequently, they were crowded out by the more aggressive Anglo rancher and farmer. As in the case of the Indians, most of the attempts to aid the Spanish-American land owners have not been well-adapted to the peculiarities of their culture.

The important end-result of alien pressures on an indigenous semi-primitive agricultural economy has been that the lands of the Indians and the Spanish have steadily deteriorated under the baneful influences of overgrazing and overcropping; and erosion has taken a heavier and heavier toll. In these experiences the "Anglo" from the East has before him a striking object lesson of the imperative necessity of conservation of the scarce land and water resources of the semi-arid West.

While the contraction of the economic base of the Spanish culture has resulted in the dispossession of many persons, its chief result has been the creation of a permanent body of seasonal, migratory agricultural labor. The Rio Grande Valley lies athwart two of the important migratory routes for labor in the United States. The south-north route begins in Mexico and moves up through Colorado into Idaho and Montana. This is the route of seasonal labor for sugar beets, sheep-herding and lambing, and truck-crop harvesting. The east-west route follows U. S. Highway 66 from Arkansas and Oklahoma to the Pacific Coast. It is the route of the unskilled worker as well as of the dispossessed or migratory agricultural laborer. The Hispano of the Rio Grande Valley moves out from his own subsistence acreage along these routes, following the seasons and returning home with a few dollars for another year.

The effects of such an employment pattern on economic status are clearly discernable. Whether the native Hispano. 
and the immigrant Mexican move north or west in search of employment, they find that only the undesirable jobs are open to them. In agriculture they are the "stoop" jobs of hand cultivation and harvesting. In industry the jobs open to the Spanish-American are unskilled, manual labor jobs. In both agriculture and industry wages are low and the conditions of employment are poor. Living accommodations in the country are primitive and transportation is usually by truck or "special" day coach. In the cities segregation on the job is common, and segregation in living quarters is the rule.

Working as a casual, migratory laborer, as he must, the Spanish-American is also a frequent victim of unemployment. In 1940, at the time of the Census, New Mexico had the highest percentage of unemployment of any state in the Union-24 per cent of the total labor force was unemployed or on emergency public employment. In 1941, when the United States was approaching full employment, 10 per cent of the labor force of the Rio Grande area was still unemployed. In a study made in 1941 , it was found that 43 per cent of the labor force of New Mexico was located in the twelve northern counties of the state, where the Spanish concentration is heaviest, and that 69 per cent of the unemployed of the state resided in these same counties. ${ }^{9}$

New Mexico is the original home and present center of Spanish-American population in the United States, but during the last century significant numbers of the Spanish people gradually left their original settlements and became established in many of the cities and towns of the region. Here they have been joined by first- and second-generation Mexicans, so that small groups of Hispanos are found scattered rather generally throughout the region.

${ }^{9}$ Morris E. Garnsey: Employment Trends in New Mexico. Unpublished quarterly report to the National Resources Planning Board, September 1941 . 
Wherever they are found their economic status is that of a minority group. The Hispanos, like the Indians, live in a social environment which is quite frequently hostile to them. Theirs is the status of the second-class citizen. Frequently they cannot buy services or merchandise on the same terms as the Anglo. The Spanish-American cannot accumulate capital, either from his own savings or from borrowing, either for business or farming. Job opportunities in towns and cities are strictly limited. Even the services of government are not always open to the Hispano on equal termsparticularly such services as education, technical training, and social welfare. The efforts of the Hispanos to adapt themselves to the social environment are rebuffed by the majority who would rather maintain a superior position than permit the minority groups to participate equally in the society and compete with others on equal terms. Assimilation becomes impossible, and the Hispano's inferior economic status is perpetuated.

The economic problems of the minority culture groups of the Mountain West show no great divergences from the national problem. The regional situation has its own character, due to the nature of the minority cultures involved and to the relative numbers in the minority groups. The Indian is, in many ways, a special case in which the problem is mainly a national one with regional overtones. The Japanese-American has not been free from minority discrimination; but, perhaps because of the smallness of the group, the economic problem is not so acute for him as for other and larger minority elements. For the Hispano the economic aspects of minority status are serious, and the dominant groups of the region have been no more successful than Americans as a whole in finding a way to give the Hispano the freedom of economic opportunity to which his American birthright entitles him. 


\section{Migration: Past, Present, and Future}

The westward movement has been described aptly as a great tidal wave of people sweeping across the nation from coast to coast during a century and a half of settlement and conquest. Although our statistics on migration are inadequate, it is possible to get a fairly accurate idea of the magnitude and direction of population movement from data on state-of-birth and state-of-residence of the population. These data extend back to the Census of $185^{\circ}$. From them it may be observed that by $185^{\circ}$ the Atlantic states were experiencing a net emigration of population. Ohio joined the deficit group by 1860 , and by 1890 Indiana, Illinois, Wisconsin, and Louisiana were losing population to the West. By 1910 the wave of migration had swept so far past Missouri and Iowa that it created a net emigration there. By 1930 even the "western" states of Kansas and Nebraska were losing population to the newer West. ${ }^{10}$ In the 40 's the war accelerated the westward trek, and by 1948 the post-war migration was swelling the population of the Pacific states at the fastest rate in forty years. It is too early to tell if the crest of the wave now, in the late 4o's, is breaking against the barrier of the Pacific, or if the climax of the movement is yet to come. It is clear, however, that the crest has passed the Mountain West, although future accretions of population in the region by migration are not impossible.

It is interesting to trace the progress of the wave of westward migration in somewhat greater detail for the Mountain West. One way to do this is to observe, decade by decade, the extent to which the total of the American-born population living in the region has exceeded the number of individuals born in the region. Since not all those born in

${ }^{10}$ Thomas R. Smith: "The Analysis of Past Migration" in Migration and Economic Opportunity (Carter Goodrich, and others; Philadelphia, University of Pennsylvania Press, 1936), pp. 676-78. 
the region continue to live there, an immigrant is required to replace each native emigrant merely to maintain the region's population. Hence if the number of immigrants exceeds the number of those born in the region, the difference between the two figures measures the net gain of population for the region by immigration. This net gain is not a gain for a given decade as compared with the previous decade, but rather a cumulative measure of population gain through immigration. (The same individual is counted as a migrant in succeeding decades as long as he is living.) The net gain in native population through immigration for the period 1820-1940 is shown in Chart 2 for the Mountain West and the Pacific West.

It will be seen that up to 1920 the cumulative gains of population by immigration were increasing in the Mountain West. In the next two decades, however, the net gain declined-from 966,000 in 1920 to 628,000 in 1940 . Thus, by 1920 the crest of the westward wave was moving on from the Mountain West into the Pacific region. In both the 20's and 3o's the wave mounted higher on the West Coast. Nor, apparently, has it ceased to rise during the present decade. In all probability the westward movement will continue for some years to come. It remains to be seen if that movement will be directed almost solely to the Pacific Coast, or if the present "skipping over" of the Mountain West will give way before another influx of population to the region.

It may be that the period of significant immigration to the Mountain West is definitely a thing of the past. From 1920 to 1945 , through depression and war, the percentage of the national population residing in the Mountain West has remained constant at 3.15 per cent. Since 1935 the Bureau of the Census has made reliable, direct estimates of migration. These estimates show that from 1935 to 1940 six of the Mountain States experienced a net in-migration of 87,799 
persons, while in Montana and Utah there was a net outmigration of 11,129 and 12,392 persons respectively. Thus, disregarding intraregional movements, the net in-migration for the region was 64,278 persons.

During the war five of the eight states lost population to other states through civilian migration. Three other states in the region experienced significant in-migrations (See Appendix Table 20). Although these figures do not measure the net gain or loss in population for the region, they do indicate that the volume of migration in the war period 1940-5 was much larger than the movement from 1935 to 1940 and that the net in-migration of the earlier period became a net out-migration during the war. Since the war, net emigration from the Mountain States has continued despite a certain amount of back-flow after the cessation of hostilities. For the region as a whole, substantial losses in some states have been almost balanced by gains in others. Up to now the losses are not significantly large, and it would seem that the region is at present in a period of relative stability of population.

When the information on war and post-war migration is related to the long-term trend of migration as shown in Chart 2, it becomes apparent that the Mountain West is conforming to Thomas R. Smith's description of the migration pattern characteristic of the westward movement: "About three decades after the first settlement the immigration surplus reaches a maximum, and after about three more decades of decreasing surplus, emigration sets in." For the Mountain West the year of maximum surplus was 1920, so that, on this basis, the region may be expected to become an emigration area soon after $195^{11}$ (See Chart 2).

Nevertheless, before a final estimate of future migration is attempted, one other major factor must be taken into con${ }^{11}$ Smith, op. cit., p. 678. 
(IN

MILLIONS)

4

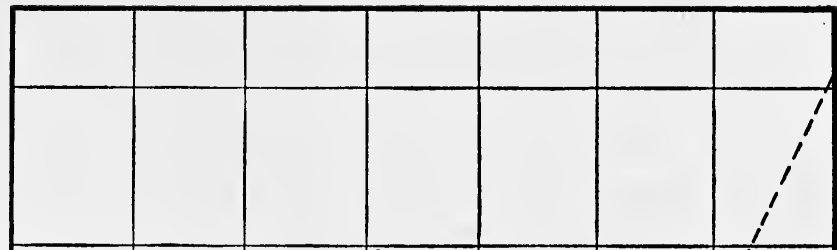

3.5

3

2.5

2

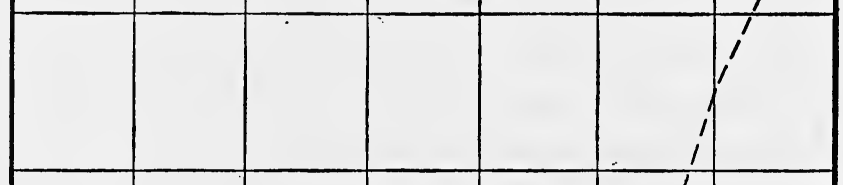

1.5

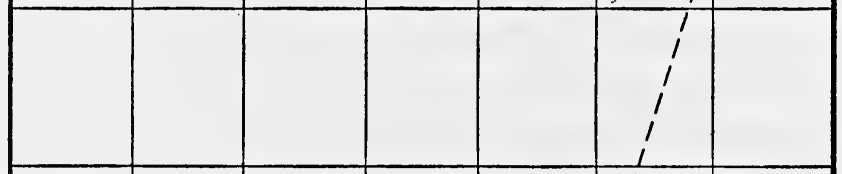

1
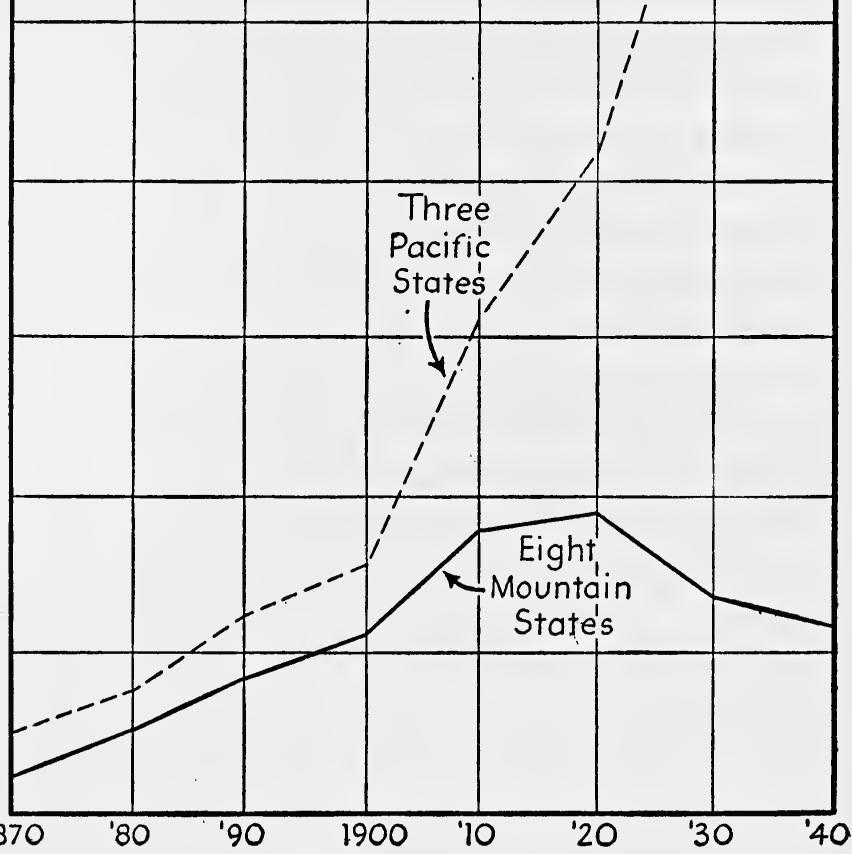

5

CHART 2

Net Gain of Population Through Interdivisional Movement:

Mountain and Pacific (I870-1940)

Source: United States Bureau of the Census, Population: State of Birth of the Native Population. 16th Census of the United States: 1940. (Washington, D. C., United States Government Printing Office, 1944), Table, 9, pp. 6-7. 
sideration. It is the effect on migration of the industrialization process. In general the westward movement has been the result of the agricultural settlement and development of the country-or perhaps more accurately of resources development. After $185^{\circ}$ the nation also experienced an industrial growth which produced a major migratory movement and attracted population to the urban areas of industrial concentration. This movement of population in response to expanding job opportunities may be observed on the Atlantic seaboard around $185^{\circ}-60$, in Illinois after 1890 , and in Michigan and Indiana after 1920.

If industrial decentralization becomes important and if the hydroelectric power and mineral resources of the Mountain West are exploited fully, a new industrially motivated migration of population to the West could be expected to follow. Already there are signs of such an eventuality. Some industrialization is taking place in the Mountain West, largely as a result of war plant investment. This new activity has been accompanied by a rapid growth of the urban-industrial centers of the region. The two largest of these, Denver and Salt Lake City, were surveyed by the Bureau of the Census in April 1947 and it was found that the population of metropolitan Denver was 23 per cent greater than the population in 1940. For metropolitan Salt Lake the increase was 20 per cent. Only nine of the 34 metropolitan districts surveyed by the Bureau of the Census had experienced a greater growth between 1940 and 1947. Of these, four were on the West Coast and two in Texas. ${ }^{12}$ Thus, it may be concluded that the industrialization of the West, which is embryonic in the Mountain West and flourishing on the Pacific

12 United States Bureau of the Census, Current Population Reports: Population Characteristics. Series P-21. No. 35. Population Characteristics of Metropolitan Districts: April, 1947. (Summary report) (Washington, D. C., August 24, 1947). 
Coast, may be expected to prolong the original westward movement beyond its anticipated termination.

Whatever the future may bring, it is important to realize that as of today the influence of the westward movement on the contemporary population of the Mountain West is still strong. In 1940 more than one-third of the native population residing in the region was born elsewhere in the United States. The region's proportion of "immigrant population" far exceeded that of any other Census Division, except the Pacific where half the population is immigrant. ${ }^{13}$ The population of the Mountain West is still that of "new country" and the people still claim many of the characteristics of a frontier society.

13 Per cent of Native Population Living in the Division but Born in Other Divisions, 1940.

$\begin{array}{lc}\quad \text { Division } & \text { Per cent Born in Other Divisions } \\ \text { New England } & 7 \cdot 7 \\ \text { Middle Atlantic } & 9 \cdot 4 \\ \text { East N. Central } & 14.7 \\ \text { West N. Central } & 13.8 \\ \text { South Atlantic } & 9.2 \\ \text { East S. Central } & 6.7 \\ \text { West S. Central } & 13.7 \\ \text { Mountain } & 37.8 \\ \text { Pacific } & 52.0\end{array}$

(From United States Bureau of the Census, Population: State of Birth of the Native Population, loc. cit.). 


\section{Chapter 0. The Labor Force and Employment}

The preceding discussion of recent and anticipated changes in the population of the Mountain West naturally gives rise to questions concerning the corresponding fluctuations in the labor force and employment. How large was the labor force in 194 o? How fully was it employed? What was the manpower contribution of the region to the war effort? How large is the post-war labor force, and how is it to be employed?

A carefully worked-out answer to most of these questions is available in a study of state and regional variations in the labor force published by the Bureau of Labor Statistics in $1947 .{ }^{1}$ Its most significant results are summarized in Table 3 , which shows the estimated size of the labor force in the Mountain West, by states, in $194^{\circ}, 1945$, and $195^{\circ}$.

From 1940 to 1945 the labor force of the Mountain West increased by 268,000 , or 17 per cent. Because there was a net emigration of population of at least 69 ,ooo during this

1 United States Department of Labor, Bureau of Labor Statistics: State and Regional Variations in Prospective Labor Supply. Bulletin No. 893 (Washington, D. C., United States Government Printing Office, 1947). 


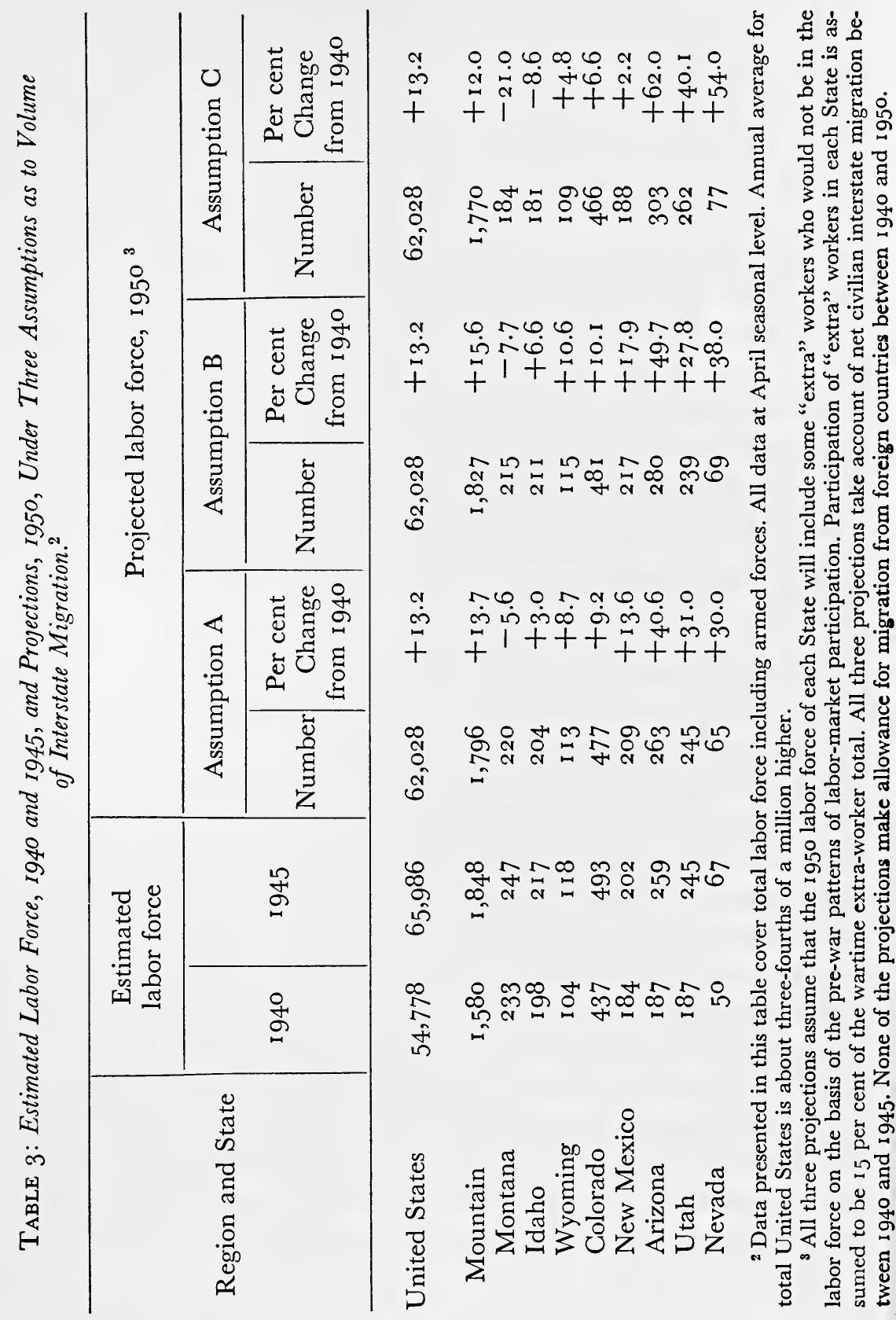


period, it follows that "extra" workers were drawn into the labor force of the region in large numbers during the war. In fact, when the regional labor force and the "emigrant" force are added, it would appear that the wartime manpower contribution of the Mountain West was somewhat greater than the national contribution. For on this basis the region's labor force had increased in 1945 by 21.4 per cent over 1940, as compared with a national increase of 20.4 per cent for the same period.

On the other hand, the fact that the Mountain West served as a labor reservoir during the war is not without its dangers to the regional economy in the post-war period. Many of the wartime migrants have not returned to the region, and the dynamic effects of war-generated activity in other regions may even encourage a further out-migration at something like the war-period rate.

This latter eventuality is assumed in arriving at the projection of the 1950 labor force in Assumption C of the table. Here it is postulated that interstate migration between 1945 and $195^{\circ}$ will equal the net interstate migration of civilian workers between 1940 and 1945 . On this basis the labor force of the Mountain West in $195^{\circ}$ would amount to $1,700,000$ persons. This number would be 2.85 per cent of the national labor force in $195^{\circ}$, while in $194^{\circ}$ the region possessed 2.88 per cent of the national labor force.

An opposite condition is presented in Assumption B which supposes that the net number of workers who move between states during the post-war period, $1945^{-50}$, will be the same as would be expected on the basis of the 1935-4o experience. Because this earlier period witnessed a net immigration to the Mountain West, the projected labor force in $195^{\circ}$, with in-migration assumed, rises to $1,827,000$ or 2.95 per cent of the national labor force.

A third assumption (Assumption A) presumes that there 
will be no net effect of migration on the labor force from 1945 to $195^{\circ}$; and, consequently, this estimate of $1,796,000$ persons in the labor force falls between the two opposing assumptions of out-migration and in-migration. In the preceding chapter considerable evidence was brought forward to support the view that the Mountain West is approaching a period of relative stability of population; therefore this last estimate would seem to be the most likely one for $195^{\circ}$. Such a labor force would be 13.7 per cent greater than in 1940, as compared with a 13.3 per cent growth in the national labor force during the decade. Also, the regional labor force would account for 2.90 per cent of the total labor force, which represents practically the same regional share as the 2.88 per cent of 1940 .

\section{Possibilities for Employment in 1950}

What are the possibilities for the employment of a labor force of this size in the Mountain West? The answer to this question depends in part on an understanding of the influence on contemporary employment of the region's employment experience in the recent past. Here, unfortunately, the record is not too good. In 1940, at the time of the Census, the percentage of the total population over 14 years of age in the labor force was smaller in the Mountain West than in any other Census Division in the country. Yet the Mountain States had the highest percentage of unemployed workers of any region and, also, the highest percentage of persons employed on emergency public work. A comparison of the region with the nation as a whole further emphasizes the extent of unemployment in the Mountain West in 1940: ${ }^{4}$

4 United States Bureau of the Census: Population. Vol. II. Characteristics of the Population. Part I. United States Summary and AlabamaDistrict of Columbia. 16th Census of the United States: 1940 (Washington, D. C., United States Government Printing Office, 1943), Table 37, p. 9o. 
In the United States

in the Mountain West only

In the United States

in the Mountain West

In the United States in the Mountain West
85.6 per cent of the labor force was employed;

82.7 per cent.

4.8 per cent was employed on emergency public work;

7.I per cent.

9.6 per cent was seeking work;

I 0.2 per cent.

Clearly, unemployment was a serious problem in the Mountain West in 1940. Moreover, improvement in the region was slow after 1940 so that when the war demand for labor began the region served as a reservoir of labor for the war production areas. Shipyards and aircraft factories drew the skilled and semi-skilled "Anglo" workers, while the Hispano's and Indians found employment on railroads, farms, and construction projects.

After the war a return flow set in, and a significant number of migrants came back to the region, attracted by conditions of full employment and high agricultural income. As a result, total employment in 1946 was greater than in 1945 when the war conditions still prevailed. It is estimated that there were $1,570,000$ persons employed in the Mountain West in October 1946, and only about 23 ,ooo unemployed. ${ }^{5}$

However, this extraordinarily high level of employment falls short of the minimum estimated job requirements for $195^{\circ}$ by some 200,000 jobs. The experience of the past decade points to the conclusion that the present economy of

5 The New American Market. (Reports reprinted from Business Week; New York, McGraw-Hill Publishing Company, 1947). This study is based on official United States government employment data from the Bureau of Labor Statistics, the Department of Agriculture, and the Bureau of the Census. Unfortunately publication of data on "employees in non-agricultural establishment by states," formerly supplied by the Bureau of Labor Statistics, was discontinued in December 1946. Without these data it has been impossible to estimate total employment by states for 1947 and 1948 . 
the Mountain West cannot provide employment for all the members of a labor force of the size anticipated for 1950 . It seems useful, therefore, to examine the possibilities for the expansion of employment inherent in the regional economy. The first step in such an examination is an analysis of the industrial pattern of the region. If more jobs are needed to provide employment for the region's labor force, it is necessary to discover, industry by industry, those areas in which potentialities for expansion exist. This is the purpose of the following chapter. 


\section{Chapter Y. Production in the Mountain West}

The Mountain West is a reasonably homogeneous region with a foundation of physical resources, a labor force, and a pattern of economic activity uniquely its own. Its people, however, are a part of a larger homogeneous group which we usually call "American;" and its pattern of production is an integral part of the productive pattern of the larger national economy. A description of the production of the region, therefore, necessarily involves a comparison of the regional economy with the productive activity of the national economy. To what extent is the Mountain West a specialized sub-division of the national economy? In what directions is it specialized? To what extent does it repeat the national pattern within its own boundaries?

Many types of economic activity are common to every part of the United States. The production of food and fiber, the provision of facilities for trade and services, and the activities of government and the professions are found everywhere. At the same time, however, specialization undoubtedly exists. Iowa is an agricultural state even though manu- 
facturing takes place there. Connecticut specializes in manufacturing although it grows tobacco, too. Thus on balance a state or a region specializes, and the region's contribution to the national economy is in part a specialized one.

Perhaps the best general measure of specialization or diversification in the economic pattern of a region is the distribution of its employment among the various types of economic activity. Such a distribution for the United States and for the Mountain West is given in the following table which shows the percentage distribution of employed workers by industry groups for the nation and for the region. In addition, the deviations of the regional pattern from the national pattern of employment are shown in column 3 .

The production, pattern of the region now emerges clearly. The Mountain West is a region which is specialized noticeably in agriculture and mining, and to a lesser extent in transportation-communication. At the same time, it is notably deficient in manufacturing. Moreover, a comparison with other regions brings out the fact that no other region of the United States is as deficient in manufacturing as the Mountain West. Even the Southern and Midwestern states, which are more highly specialized in agriculture than the West, have a greater percentage of their employment in manufacturing than the Mountain West. ${ }^{1}$ Thus, the source of the fundamental unbalance in the Mountain economy stands sharply revealed.

\section{The Dispersion of Productive Activities Within the Region}

The degree of specialization and unbalance in the economy of the Mountain West can be seen even more clearly

1 National Resources Planning Board: Industrial Location and $\mathrm{Na}$ tional Resources (Washington, D. C., United States Government Printing Office, 1943), Table 5, p. 121. 
TABle 4: Percentage Distribution of Employed Workers in Major Industry Groups-United States and Mountain West-and Deviations of the Mountain West from the United States Industrial Pattern-1940.

\begin{tabular}{|c|c|c|c|}
\hline \multirow[t]{2}{*}{ Major Industry Group } & $\begin{array}{l}\text { United } \\
\text { States }\end{array}$ & $\begin{array}{l}\text { Mountain } \\
\text { West }\end{array}$ & $\begin{array}{c}\text { Deviation } \\
\text { of Moun- } \\
\text { tain West } \\
\text { from United } \\
\text { States }\end{array}$ \\
\hline & Per cent & Per cent & $\begin{array}{l}\text { Percentage } \\
\text { points }\end{array}$ \\
\hline Agriculture & I 8.54 & 26.03 & $7 \cdot 49$ \\
\hline Forestry and Fishing & 0.23 & 0.24 &. $\mathrm{OI}$ \\
\hline Coal-mining & 1.17 & I. 42 & .25 \\
\hline Oil and gas wells & $0.4 \mathrm{I}$ & 0.49 & .08 \\
\hline Other mines and quarries & 0.45 & 4.47 & 4.02 \\
\hline Construction & $4 \cdot 55$ & 5.26 & $.7 \mathrm{I}$ \\
\hline Manufacturing & $23 \cdot 4^{1}$ & $8.4^{2}$ & - I 4.99 \\
\hline $\begin{array}{l}\text { Transportation, Communi- } \\
\text { cation, etc. }\end{array}$ & 6.89 & 8.30 & I. $4 \mathrm{I}$ \\
\hline $\begin{array}{l}\text { Wholesale and retail trade } \\
\text { Finance, insurance and real }\end{array}$ & 16.69 & 17.43 & .74 \\
\hline estate & $3 \cdot 25$ & $2 \cdot 31$ & -.94 \\
\hline Business and repair services & I.9I & 2.26 & .35 \\
\hline Personal services & 8.88 & $7 \cdot 43$ & -1.45 \\
\hline $\begin{array}{l}\text { Amusement, recreation, etc. } \\
\text { Professional and related serv- }\end{array}$ & 0.88 & 0.95 & .07 \\
\hline ices & $7 \cdot 35$ & 8.46 & I.I I \\
\hline Government & 3.88 & 5.01 & I.I 3 \\
\hline Industry not reported & I.53 & $1.5^{2}$ & -.01 \\
\hline Total & 100.00 & I 00.00 & - \\
\hline
\end{tabular}

Source: National Resources Planning Board: Industrial Location and National Resources (Washington, D. C., United States Government Printing Office, 1943), pp. 120-1. 
when comparisons with the national pattern are made by states rather than with reference to the larger unit of the region. Table 5 shows the deviations of each of the eight states of the region from the United States industrial pattern.

Several important points emerge from an examination of this table. The states of the region are by no means homogeneous in industrial pattern. Colorado stands out here as a strongly diversified state. The deviations of its employment pattern from the national pattern are not large, with the single exception of manufacturing. As a matter of fact, Colorado ranks fourth among all the states in degree of diversification. ${ }^{2}$ Utah in fifteenth place in degree of diversification and Arizona in seventeenth might also be regarded as diversified states. The other five states are distinctly specialized in character-mainly, of course, in agriculture and in mining. The three "diversified" states are, nevertheless, strongly deficient in manufacturing. Even Colorado, where diversity is extensive in other respects, has a large deficiency in manufacturing. Here again, the essential unbalance of the region is clearly shown.

A further examination of the data on manufacturing established the existence of a concentration of manufacturing activity at a few centers within the region. These clusters are found mainly in Colorado and Utah. In 1947 the number of production workers in manufacturing in the entire region amounted to about 119,0oo. Nevertheless, more than onethird of this regional total, 44,0oo, was in Colorado; and another 20,000 persons were employed in manufacturing in Utah. Thus there is a regional pattern in which Colorado forms the primary nucleus of the regional economy, with Utah, and Montana-Idaho forming secondary nuclei. Since manufacturing, finance, and distribution facilities tend to be centralized in urban areas, the loci of industrial concentra-

2 National Resources Planning Board, op. cit., Table 6, p. 123. 


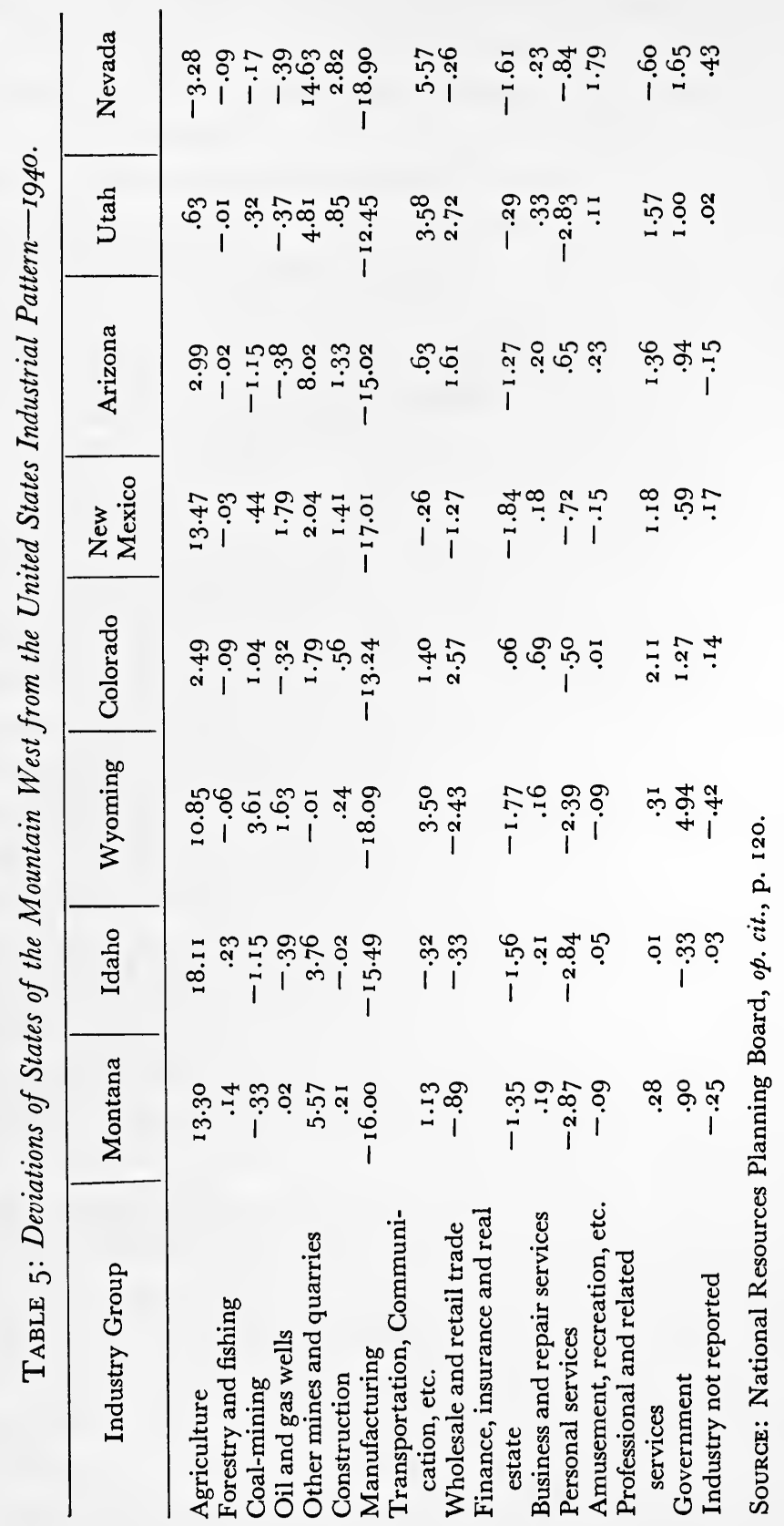


tion in the region can be further defined. The central nucleus in Colorado is reduced to the Denver-Pueblo axis along the Eastern slope of the mountains. The secondary center in Utah is based on an Ogden-Salt Lake-Provo axis, while Phoenix and Albuquerque form the centers of urban industrial development in Arizona and New Mexico.

From this description a final, over-all picture emerges. The Mountain West as a region is specialized in agriculture and mining, and its manufacturing activity has lagged far behind national development. Within the Mountain West specialization has been carried far in the sub-areas of the region, while centers of concentration of industry and population which create a cohesive regional pattern have developed.

The chief reason for the origin and growth of regional and sub-regional specialization in the Mountain West already has been made apparent in previous chapters. The people of the region have made use, naturally and directly, of the physical resources at hand. But why have they failed to manufacture and process these same materials, adding value to them by their own labor and augmenting their own income? Perhaps a brief examination of the major factors which affect industrial location will yield an answer.

\section{Determinants of Underdevelopment in Manufacturing in the Mountain West}

According to a study of the Department of Commerce there are thirteen basic factors which usually govern the location of an industrial plant: (1) location of production materials; (2) labor; (3) sites; (4) industrial fuel; (5) transportation facilities; (6) market; (7) distribution facilities; (8) power; (9) water; (10) living conditions; (1 1) laws and regula- 
tions; (12) tax structure; and (13) climate. ${ }^{3}$ These factors are listed roughly in order of their importance, but it should be emphasized that the location of a given plant depends upon the complex relationship among the thirteen for that particular set of circumstances. In some cases one factor will dominate, and all other considerations will become subordinate. In other cases, the various locational pulls will be almost equal and a factor which ordinarily is of secondary importance will be the decisive factor for this particular plant. It follows that in order to explain the causes of regional underemphasis on manufacturing in the Mountain West it is necessary to look more closely at the location pattern of the region, examining each type of manufacturing in turn.

A study of the location of manufacturing throughout the United States has shown that some industries are definitely localized in well-defined spots in the national economy. ${ }^{4}$ An obvious example of this kind of industry is the canned fish industry. By contrast there are other manufacturing industries, such as the newspaper and job printing industries, which are located with reference to factors which are found nearly everywhere throughout the economy. Such industries are properly referred to as "non-localized."

Within a given state or region both localized and nonlocalized industries will exist. Some of these will be important in the regional economy, others relatively unimportant. ${ }^{5}$ If we combine this latter characteristic of a region's manufacturing with the former distinction, a fourfold classification of manufacturing in the regional economy results: (1) local-

${ }^{3}$ U. S. Dept of Commerce, Office of Domestic Commerce: Basic Industrial Location Factors, Industrial Series No. 74, (Revised June, 1947; Washington D. C., U. S. Government Printing Office, 1917).

${ }^{4} \mathrm{~A}$ "localized" industry is more precisely described as one having a high coefficient of localization. For a definition of this measure and a list of coefficients for 127 leading types of manufacturing see National Resources Planning Board, op. cit., pp. 107-119.

${ }_{5}$ An important industry in a state or region is better defined as one having a high location quotient. See loc. cit. 
Location Characteristics of

Manufacturing in the Mountain West

\begin{tabular}{|c|c|c|}
\hline $\begin{array}{l}\text { BASIC RAW } \\
\text { MATERIALS: }\end{array}$ & PRIMARY PROCESSING: & $\begin{array}{l}\text { END-PRODUCT } \\
\text { PROCESSING: }\end{array}$ \\
\hline Grains & $\begin{array}{l}\text { FLOUR, FEED- } \\
\text { STUFFS }\end{array}$ & Bread, biscuits, etc. \\
\hline Sugar Beets & Sugar & Candy and confectionery \\
\hline Fruits and Vegetables & & $\begin{array}{l}\text { Canned Fruits, Vege- } \\
\text { tables }\end{array}$ \\
\hline Milk & & Creamery Butter \\
\hline Cattle and Sheep & Dressed fresh meat & Meat products \\
\hline Hides & Tanning & Shoes \\
\hline Wool & Scouring & $\begin{array}{l}\text { Woolens and wor- } \\
\text { steds }\end{array}$ \\
\hline \multirow[t]{7}{*}{ Timber } & LOGGING & Dimension, seasoned \\
\hline & SAW Mills & lumber \\
\hline & Wood Preserving & Mill worked lumber \\
\hline & $\begin{array}{l}\text { Posts, Ties, } \\
\text { Mine Props }\end{array}$ & $\begin{array}{l}\text { Boxes and crates } \\
\text { Furniture }\end{array}$ \\
\hline & Pulp & Paper products \\
\hline & & Newspapers \\
\hline & & $\begin{array}{c}\text { Rubber Tires, Tubes, } \\
\text { Belts, Etc. }\end{array}$ \\
\hline Clay & Brick and Tile & \\
\hline Petroleum & $\begin{array}{l}\text { Refined Oils } \\
\text { and Gasoline }\end{array}$ & \\
\hline Potash & FERTILIZERS & \\
\hline Phosphates & Fertilizers & \\
\hline Iron Ore and Coal & $\begin{array}{l}\text { STEEL WORKS } \\
\text { Fabricated Steel Pro- } \\
\text { ducts }\end{array}$ & $\begin{array}{l}\text { Industrial Machinery } \\
\text { Wire and Nails }\end{array}$ \\
\hline Non-ferrous metals & $\begin{array}{l}\text { Primary and Seconda } \\
\text { Smelting }\end{array}$ & ary Foundaries: \\
\hline
\end{tabular}

KEY:

Products of localized industries important in the region: FLOUR

Products of non-localized industries important in the region: Newspapers

Products of localized industries unimportant in the region: Wool Scouring

Products of non-localized industries unimportant in the region: Tanning 
ized industries, important in the region; (2) nonlocalized industries important in the region; (3) localized industries unimportant in the region; (4) nonlocalized industries unimportant in the region.

Such a classification is presented for the Mountain West in tabular form on page 106.

Several important observations emerge from a study of this list of industries:

Every type of manufacturing rated as important in the Mountain West is based on the utilization of the raw materials of the region, except rubber products and newspapers. Most of the important ones are also "localized" type industries, being tied to the raw materials which they process. Examples are beet sugar, flour, and native lumber.

In a few cases local initiative has succeeded in establishing nonlocalized industries in the Mountain West and in developing them to a place of regional importance in competition with similar industries in other regions. In all these cases, however, the raw materials are easily available in the region. Examples are canned fruits and vegetables, industrial machinery, and fabricated steel.

A number of raw materials are found in the region in significant amounts, but they are processed regionally to an unimportant extent, or not at all. In some cases processing is localized nationally in other parts of the United States. Examples are wool scouring, woolens, and the smelting and refining of non-ferrous metals.

There is a large group of nonlocalized manufacturing industries, which are regionally unimportant despite the presence of requisite raw materials in the region. Most of

Source: National Resources Planning Board: Industrial Location and National Resources (Washington, D. C., United States Government Printing Office, 1943), Chap. V, Table 2 and United States Bureau of the Census: Census of Manufactures: 1939 (Washington, D. C., United States Government Printing Office, 1940). 
these industries represent advanced stages of the manufacturing process. Examples are meat packing, furniture, paper products, and non-ferrous metals products.

From these observations we may conclude that it is not too difficult to find the reasons for the location in the Mountain West of the types of manufacturing which actually exist there. It is more difficult to explain the absence of other types of manufacturing which might reasonably be expected to be found in the Mountain West, particularly when the requisite raw materials are present in adequate amounts. Undoubtedly various factors or combinations of factors among the thirteen determinants of location cited above are, or have been, unfavorable to location in the Mountain West. Among these the most important have been restricted markets, inferiority of local materials, freight rate differentials, and fuel and power costs. Some of these are no longer as important as they once were, at least in certain cases. Conditions regarding others have changed but little in recent years. A few examples will be sufficient to illustrate the nature of the problems faced by the Mountain West in attempting to increase the manufacturing activity of the region.

LOCATION OF. PRODUCTION MATERIALS It is easy to explain the existence of the beet sugar refining industry in the Mountain West. Beets are grown there because of a most favorable combination of soil, water, and climate. In the processing of the beet there is a great loss of weight. Consequently it is cheaper to ship the finished product than the raw material. The industry is a materials-orientated industry, the location of the material dominating and subordinating the other factors which govern location.

Paper mills also are located near the source of materials for the same reason. But the pine, spruce, and aspen of the Rocky Mountains have been inferior to the timber of the 
Northwest and the South for most purposes so that the finished lumber and paper industries have not developed here. Recently, technological improvements (plus shortages elsewhere) have made it possible to utilize beetle-killed Englemann spruce for pulp and paper. At first this timber was shipped to Wisconsin for processing, but in 1949 definite plans were announced for the establishment of a plant in western Colorado to produce newsprint from the beetlekilled spruce. This plant will employ 700 men, a large number for a western enterprise. It is scheduled for operation in $195^{1.6}$

LABOR Labor is an important locational factor in many industries and the decisive factor in a few. The importance of labor for plant location turns on characteristics of wage rates, skills, supply, and attitudes. Unfortunately, there is little data on regional wage differentials. The data on wage variations among regions which have been collected by the Bureau of Labor Statistics reflect the relative insignificance of the Mountain West in total national employment. The major study of the Bureau omits the region entirely because it accounts for less than one per cent of manufacturing employment. On the basis of random sampling of wage rate data for some of the cities of the Mountain West it appeared that hourly wage rates in manufacturing in the region are about equal to the United States average. This is true of meat packing, machinery, and confectionery. On the other hand, wage rates in foundries are below the national average.

It is significant that wage rates in trade and service occupations in the Mountain West seem to be substantially lower than the national average. Wages of women workers

${ }^{6}$ In October 1949 announcement was made of plans for construction of a paper mill in Polson, Montana, in $195^{\circ}$ and a second mill in Coeur d'Alene, Idaho, in $195^{1}$ employing a total of 1000 workers. (The Denver Post, October 1, 1949). 
in all occupations apparently are lower than the average of women's wages elsewhere. ${ }^{7}$ A recent authoritative analysis of industrial migration to the South concludes that wages have become less important as locational factors, and that the supply of workers and their attitudes toward unionization have become more important. ${ }^{8}$ In all probability this generalization holds good for the Mountain West. In a study of the post-war movement for industry into Colorado Springs, Colorado, it was discovered that the availability of nonunion men was an important factor in the location preference of plants which employed $6_{5}$ or more workers. ${ }^{9}$

To take another example, it has been noticed that in recent years a good beginning has been made in the regional manufacture of such products as jewelry, toys, and precision instruments. These industries require skilled labor, and their products are of high value in relation to weight, so they can locate without regard for market. At least four fairly large producers of these products have located in Colorado alone since the war, partly in response to labor availability. Such movement of small industry represents a net gain for the region but it does not touch the fundamental problem of underemployment, because most of the excess labor supply of the Mountain West is unskilled. If labor availability alone determined location, an industrial migration to the Mountain West in the 5o's and 6o's could be predicted with confidence.

${ }^{7}$ Joseph W. Bloch: "Regional Wage Differentials: 19o7-46," U. S. Department of Labor, Bureau of Labor Statistics, Monthly Labor Review, Vol. 66 (April 1948), pp. 371-7.

See also Monthly Labor Review issues of January and November 1947; January, March, and April 1948.

${ }^{8}$ Glenn E. McLaughlin and Stefan Robock: Why Industry Moves South, NPA Committee of the South, Report No. 3, (Washington D. C., National Planning Association, 1949).

${ }^{9}$ F. R. Funk: An Analysis of the Post-IVar Movement of Industry into Colorado Springs, Colorado, in Terms of Location Theory (Master's thesis, University of Colorado, typewritten; Boulder, Colorado, 1948). 
SITES After a given area or region has been selected for the location of a new plant it is necessary to choose the precise site upon which the plant will stand. Ordinarily, the plant engineer who examines alternative sites is concerned with such problems as terrain, types of soil, highways, and rail sidings. Most of these are not significant for this study: but recently there has been an unusual and important site factor to consider. After the war when construction materials were scarce and prices high a premium developed on available buildings suitable for easy and quick adaptation to new manufacturing enterprises. Where such buildings existed they usually were in the form of abandoned war plants, and a community with surplus war plants to offer to industry stood in a favorable position for attracting new manufacturing enterprises. However, as we have seen in Chapter 3, the surplus war plants of the Mountain West were converted more slowly than were the plants of other areas, perhaps because local promotion was lacking in many western cities.

An example of a successful conversion is the establishment in the Pueblo Ordnance Depot of the manufacturing plant of the Triplex Corporation of America, which plans to employ 300 persons in the manufacture of automobile pistons by $195^{\circ}$. This was a fairly rare case of the physical relocation of a plant, the machinery and equipment being transported from the old plant in Chicago to the new site in Pueblo. Nevertheless, in many other cases the availability of war plant sites in the Mountain West has not been sufficient to overcome the locational pull of the more favorable location factors in other regions.

INDUSTRIAL FUEL AND POWER The effects of fuel costs on industrial location cannot be illustrated in specific cases without reference to fairly complex cost analyses. There is, however, a general relationship of direct significance. Of 
some 326 manufacturing industries in the United States, 68 are classified as primarily raw-materials-using industries. This small group accounts for almost half of all the fuels and electric energy used by all of the 326 manufacturing industries. Fuels and power add relatively more to the value of manufactured products in the initial processing stages than they do in the later stages of manufacture.

Since much of the manufacturing in the Mountain West is raw-materials-processing it is not surprising that many of the Mountain States rank very high in the consumption of fuels in manufacturing. In 1939 Nevada was first among all the states in per capita fuel consumption as measured in British Thermal Units per wage earner, and Wyoming was second. ${ }^{10}$ Utah stood in fourth place and Colorado in fifth place. Pennsylvania was the largest gross consumer of fuels in the United States, but its consumption per wage earner was less than half that of the western states.

It is apparent that fuel is a very important cost item for many of the manufacturing enterprises in the West. Fortunately large deposits of coal are available locally and over-all fuel costs measured in terms of millions of BTU's consumed have not been high. In 1939 the average cost per million units was 14.9 cents in the Mountain West as compared with the United States average of 15.8 cents.

On the other hand, electric power costs are not so favorable for regional expansion. In 1946, for example, industrial power cost more in Denver, Salt Lake, and Phoenix than in cities of the Pacific Coast and Southwest where manufactur-

10 National Resources Planning Board, op. cit., p. 166:

\begin{tabular}{|c|c|c|c|c|c|c|}
\hline Nevada & 2,971 & million & BTU's & per & wage & earner. \\
\hline Wyoming & 2,829 & “ & “ & “ & “ & “ \\
\hline Texas & 2,654 & “ & “ & “ & “ & “ \\
\hline Utah & 2,498 & “ & “ & “ & “ & “6 \\
\hline Colorado & 2,078 & “ & “ & “ & “ & “6 \\
\hline
\end{tabular}


ing is expanding rapidly. ${ }^{11}$ Apparently, power and fuel costs will have to be reduced in order to enable the manufacturing industries of the Mountain West to compete successfully with other regions. Without competitive power rates the Mountain West must either forego the further development of some types of manufacturing, or the regional industry must compensate for higher power costs by lower wage rates or similar economies. As long as the region's manufactures are based on raw materials processing, fuel and power will be an important item in costs. The need for the full development of the hydroelectric power potential of the region thus becomes imperative.

TRANSPORTATION FACILITIES Physical factors of transportation are of course important in location. In general, the Mountain West is well provided with air, rail, and truck transport facilities. But rates are also important, and here lies a serious obstacle to the industrialization of the Mountain West.

Perhaps the most striking example of the effects of freight rate differentials on regional processing is the case of the meat packing industry in Denver. Before 1945, the rate on fresh meat from Denver to the West Coast was about twice the rate on live cattle. This rate favored the shipment of live animals from the cattle area to the consuming centers on watt hour:

${ }^{11}$ Range of average charges for industrial service in cents per kilo-

$\begin{array}{lllr}\text { Phoenix, Ariz. } & 2.11 & \text { to } & .97 \\ \text { Salt Lake City, Utah } & 1.99 & \text { to } & 1.60 \\ \text { Denver, Colo. } & 2.40 & \text { to } & 1.14 \\ \text { Houston, Texas } & 1.85 & \text { to } & .94 \\ \text { Galveston, Texas } & 1.85 & \text { to } & .84 \\ \text { Los Angeles, Calif. } & 1.94 & \text { to } & .95 \\ \text { San Francisco, Calif. } & 1.75 & \text { to } & .88 \\ \text { Portland, Ore. } & 1.53 & \text { to } & .69 \\ \text { Knoxville, Tenn. } & 1.30 & \text { to } & .60\end{array}$

Source: Federal Power Commission, Typical Electric Bills: 1946. (Washington, D. C., May, 1946). 
the Coast. A revision of rates in 1945 reduced the differential to about 100 to 140 . As a result, fresh meat and packing-house products began to move from Denver to the Pacific Coast. By 1948, such shipments had reached an annual average of approximately 4 ,ooo carloads, as compared with the negligible shipments in pre-war years. Thus a single adjustment in the rate differentials has greatly stimulated the indigenous processing of one of the Mountain West's basic agricultural products (See below, Chapter 13).

MARKETS AND DISTRIBUTION FACILITIES Access to markets and facilities for distribution are important locational factors. The existence of the many branch plants in the Mountain West is evidence of the locational advantage of being near markets. Armour, Swift, Cudahy, duPont, CocaCola, and many others have branches in the Mountain West to supply western markets.

The restricted market of a sparcely populated region undoubtedly has discouraged the establishment of certain manufacturing industries in the West. A good example is the phosphate industry. There are three well-known phosphate rock deposits. Those in Tennessee are the closest to the chief market; and large supply of coke and electric power, which is necessary for the production of phosphate, is readily available in the area. These deposits are rather small, and are being used up rapidly. The nation's largest reserves of phosphate exist in the Mountain West in the states of Montana, Idaho, Utah, and Wyoming. Some smaller deposits are found in Florida. Recently, the Florida deposits were selected for a new plant by The Victor Chemical Works because the western reserves have the disadvantage of distance from the market and higher-cost electric power and coke. ${ }^{12}$ However, western farmers do use fertilizer and the Farmers Union has been campaigning for a western phosphate industry for years. As 12 McLaughlin and Robock, op. cit., p. 63. 
the western market increases and as new supplies of hydroelectric power become available, large-scale development of the western deposits is certain to take place-perhaps in the not-too-distant future.

Wool scouring and woolen textile manufacture are also strongly attracted to the market. Now that a new textile market and producing center is growing up on the Pacific Coast, the possibilities for creating a wool scouring industry in the Mountain West, where the bulk of the domestic wool-clip is produced, seem excellent. The Department of Agriculture has established an experimental wool scouring plant in Denver. Both research and promotion activities are widespread in Colorado, Wyoming, and Montana, and a new industry is about to be born (See Chapter 14).

The gradual shift of markets to the West has been a major factor in the decision of the Kennecott Copper Company to establish the first copper refinery in the copper-producing West. The refinery is located in Utah and will refine about half of the copper formerly smelted there and shipped East for refining. The plant will be in operation in $195^{\circ}$ and will have a capacity of 12,000 tons monthly, employing about 1, ooo persons. It will supply the rapidly growing Pacific Coast market as well as certain market areas in the Middle West. In commenting on the necessity for a western refining operation in his annual report, E. T. Stannard, President of Kennecott, stated that:

"A constantly growing demand for copper in the middle west and the recent heavy increase in freight rates make it disadvantageous to continue treating at eastern refineries tonnage which has to be returned to buyers in the Middle West." 13

WATER In the semi-arid West, water is a limiting factor for every type of economic expansion. Already there are many ${ }^{13}$ The Denver Post, March, 1948. 
communities, such as Tuscon, Arizona, where the lack of adequate water now limits population growth or the addition of new industrial consumers of water. In a few places a surplus of water still exists. It is still possible, for example, to build a paper mill on the Colorado River, although there is hardly any type of manufacturing which uses more water in the production process than a pulp and paper mill.

There is an obvious distinction between the affect of water supply on the location of a plant on a given site, and the general problem of water availability on a regional scale. For some sites the scarcity of water is absolute and unremediable, but, as we have seen in earlier chapters, much can be done for the region as a whole to conserve and control the existing supplies of water through the expansion of the system of dams, reservoirs, and water works of various sorts.

LIVING CONDITIONS AND CLIMATE Living conditions affect location primarily through their effects on the labor force and labor costs. Some places are especially attractive for pleasant living. If they are sufficiently attractive, people may be willing to work there for lower wages than in other regions. There is evidence that even where a wage differential does not exist, climate and living conditions are being given more weight in the choice of industrial location than in the past. ${ }^{14}$ Several small manufacturers who have established plants in Colorado since the war have stated that climate and living conditions were the decisive factor in the choice of a location for the new enterprise. Among these are a venetian blind producer and a manufacturer of cinder building blocks.

LAWS, REgUlation, AND TAX STRUCTURE It is impossible to generalize about these factors on a region-wide basis, since state and local taxes, laws, and regulations vary widely among the eight states. None of the states and few localities have of-

14 F. R. Funk, op. cit. 
fered direct tax exemptions to attract industry. Nevada has low taxes and no state income tax, but these inducements have attracted wealth, not industry. In Colorado recent attempts to enact a severance tax on oil have been defeated in the legislature on the grounds that such a tax would discourage industry. Few western communities have given cash inducements to attract industry, although since the war some development corporations have been formed to finance the construction of factory buildings.

There are some signs of a movement to impose special taxes on the income which "foreign" corporations, particularly insurance companies, take out of the region, and to levy lower taxes on income reinvested in the region. Should such a policy actually be enacted into law in the states of the Mountain West it would act as a very sharp stimulus to regional investment. This particular location factor will bear careful watching during the next few years.

In the preceding paragraphs a number of examples have been cited to show that some of the factors of location formerly unfavorable to the growth of manufacturing in the Mountain West are now becoming relatively favorable to future expansion. Nevertheless, there are other location factors which still work to discourage Western expansion. The West is the newest part of our country. Even before it was opened to settlement there was a well-established manufacturing industry in the United States in New England and the Middle Atlantic States. The handicaps of a late beginning continue to be difficult to overcome. Prior establishment has given strength to the older enterprises and, in addition, various devices such as freight rate differentials and the basing point system have been used to reinforce the advantage of eastern plants over upstart rivals in the West. Inertia is a strong factor in locational change and sometimes its influence overcomes the decreasing costs and improving locational ad- 
vantages of newer areas. (On the other hand, some obstacles to industrial movement to the West may be overcome by the effects on location of the conscions social planning for the decentralization of inclustry which has appeared since Hiroshima. No doult this lactor will bring new industrics to the Momtain West within the next decade.

\section{Post-War Trends in Manufacturing}

In view of the success with which the Momntain West is overcoming some of the barrices to location, it is interesting to observe the post-war growth of manthaturing in the region. 'The end of the war bromght a rapid increase in civilian mamufacturing in the Inited States. Conversion to peacetime probluction was rapid, and mamulacturing employment in civilian production rose rapidly. The construction of new inclustrial lacilities also expanded rapidly. Mamulacturing activity in the Mommtain West got under way more slowly than chsewhere, hut by the end of 19.17 the increase in mamufacturing employment in the region was slightly greater than the national increase. In 1939) the region had (i7,ooo production workers in mamulactmring. This was 0.85 per ene of the national total. In 19.17 arerage employment of production workers in the region was about 110.000 or 1.00 per cent of total national production workers in mannfacturing.

The Mountain West has lagged behind the nation in the construction of new industrial facilities. however. Much has been said about the westward movement of mamufacturing since the watr. Undoubtedly, such a movement has taken place, but not to the Mommtain West. The great expansion in the post-war period has been directed toward the Pacific Coast and to Oklahoma and Texas. ()f the \$1.6 billions of new construction of manufacturing plants contracted for be- 
tween VE Day and the end of 1947, $\$ 172$ millions was in the Pacific States and $\$ 245$ millions in Texas and Oklahoma. ${ }^{15}$ In the eight states of the Mountain West, by contrast, new construction of industrial plants between VE Day and April 1948 amounted to just under $\$ 60$ millions, or roughly 3 per cent of the national total. Once again, this time in post-war manufacturing expansion, the Mountain West is being skipped over in favor of other more fortunate and more aggressive regions.

Yet the situation is not hopeless. There are signs of the appearance of a more farorable environment for manufacturing in the Mountain West, as we have seen. From these various favorable factors the W'est must draw whatever encouragement it can, for the importance of building a program for the development of manufacturing in the Mountain West hardly can be over-emphasized. Lack of manufacturing is the primary cause of lack of balance in the regional economy. Regional unbalance contributes, and has contributed, to relatively low per capita incomes and relatively high unemployment in the Mountain West. It is not good for the economic health of the region, or of the nation, to allow such regional unbalance to continue.

15 Territorial Information Department: Survey of Industrial Expansion (Chicago, January 1948), Table 4; and "Construction Reports," Engineering New's-Record, Vol. 139, November and December 1947; Vol. 140, January through April $194^{8}$.

These figures do not include the value of government-owned war plant facilities converted to private ownership and operation. Consequently, they understate the actual additions to plants in the various regions. See Chapter 3, and Appendix Table 14. 



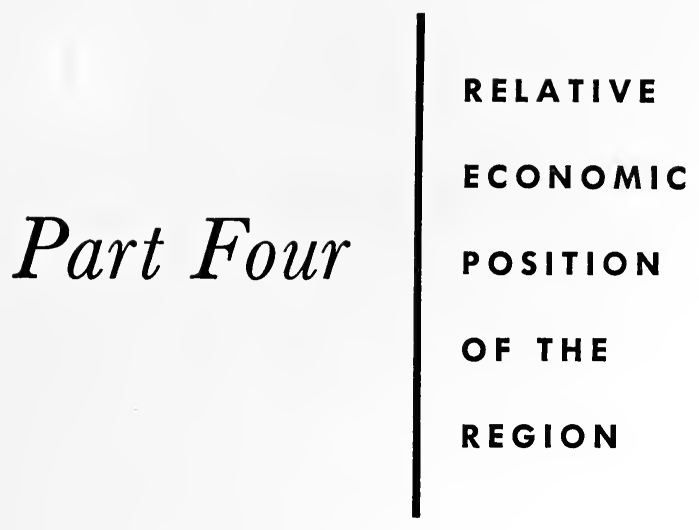



Chapter 10. Income $^{1}$

In the preceding chapters we have built up gradually a picture of the Mountain West as an economic unit, with physical features, demographic characteristics, and employment and production patterns distinctly its own. We have seen how the people of the region have made use of their natural resources to create an economic organization which produces goods and services, and yields income to the population of the region and the nation.

How effectively does this economy function? How productive is it? How does the income it yields compare with other regions of the United States? How much does it contribute to the national economy, and what does it receive in return? These are questions which occur to anyone who has observed the lack of balance in the economic structure of the region and has noticed the tendency toward underemployment which has characterized its recent history. In this chapter and the two following an attempt will be made to answer such questions by means of an examination of the income position, the relative productivity, and "balance of payments" of the region.

${ }^{1}$ Much of the analysis in this and the following chapter derives from the original work of William H. Miernyk, Instructor in Economics, University of Colorado. 


\section{Relative Income Position of the Mountain West}

In comparison with the rest of the United States, the Mountain West is a low-income region. The total income received by the citizens of the region is only about 2.5 to 3 per cent of the total of income payments to all individuals in the United States; while on a per capita basis income per person in most of the eight states usually has been substantially below the national level. The Mountain West is also a region which has shown relatively little progress in growth of income in recent years. Since 1929 significant trends in the geographic distribution of income have been clearly evident. In general there has been a shift southward and westward of income shares in the United States. The relative shares of New England and the Middle Eastern States have been declining, while income has been rising in the Southeast, Southwest, the Mountain West, and in the Far West. However, these gains have been less pronounced in the Mountain West and Great Plains than in the other Western and Southern areas.

The trend of income payments in the Mountain West since 1929 may be seen in Chart 3 and Table 6. In this chart regional income is shown as a percentage of national income and expressed in index number form for purposes of adequate comparison between regional total income and regional per capita income. ${ }^{2}$

From these data it will be seen that the share of the Mountain West in national income payments has been increasing during the last nineteen years. In 1929 the region

2 The nineteen-year period for which data are available is too short and too disturbed for completely satisfactory trend analysis. Charles F. Swartz, the leading authority on income payments to states, uses the selected years method of comparison for determining regional trends in income. Unfortunately, this method is particularly unsatisfactory for the Mountain West because the selected years are also characterized distortions and irregular influences. See Charles F. Schwartz: "Regional Trends in Income Payments," Survey of Current Business, 28:10-21, September 1948. 
received 2.5 per cent of national income payments. By the time of the post-war prosperity of $194^{6-7}$ it was receiving approximately 3 per cent. It is true that this is still a small portion of national income, but it represents roughly a 20 per cent improvement in position for the region.

There also has been an improvement in the region's per

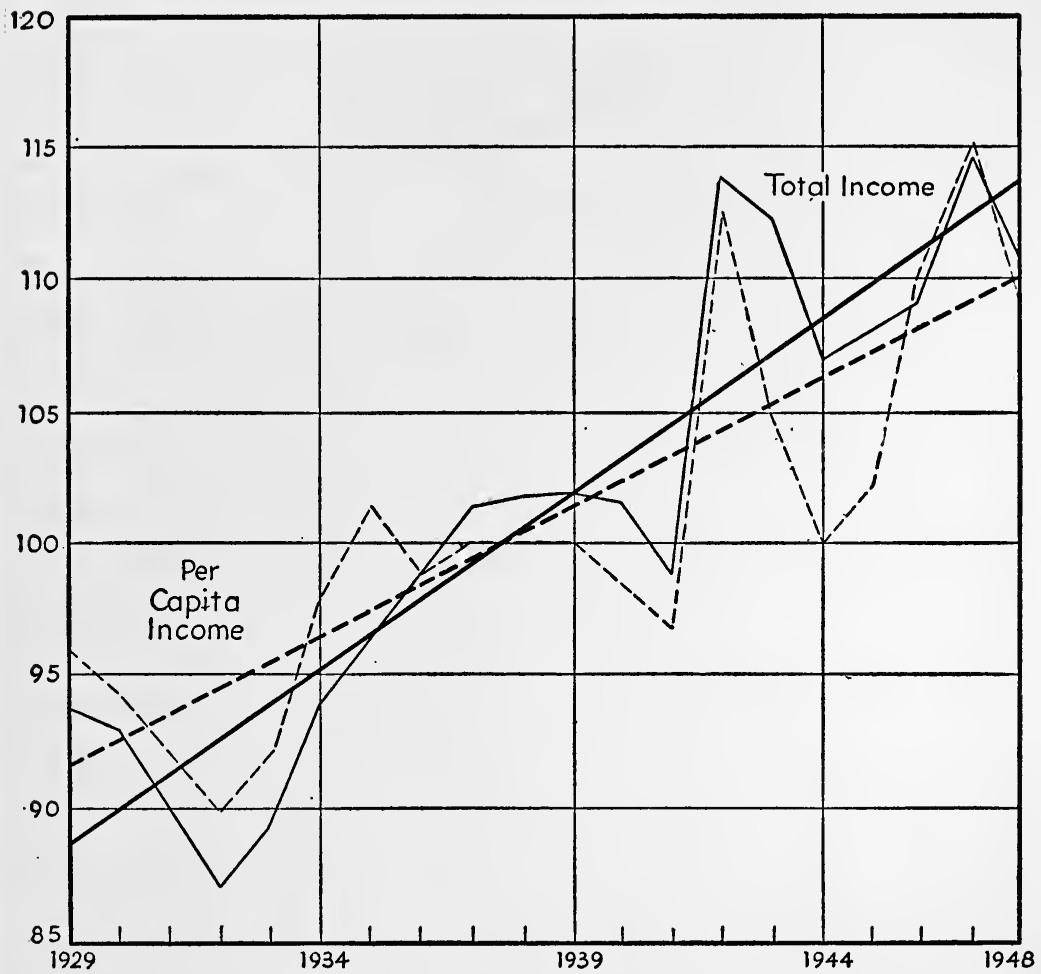

CHART 3

Trends in Regional Share of National Income Payments Index of Regional Income as a per cent of National Income

Index of Regional per capita income as a per cent of $\mathrm{Na}$ tional per capita Income

$(1935-1939=100)$

SourcE: See table 
capita income standing. However, the relative gain in per capita income during the nineteen-year period has not equaled the relative rise in total income. The slope of the trend line for the index of per capita income as a percentage of national per capita is not as steep as the trend line for

TABLE 6: Trends in Regional Share of National Income Payments

\begin{tabular}{|c|c|c|c|c|c|c|}
\hline Year & $\begin{array}{l}\text { Regional } \\
\text { Total } \\
\text { Income } \\
\text { (Millions) }\end{array}$ & $\begin{array}{c}\text { Regional } \\
\text { Per cent } \\
\text { of } \\
\text { National }\end{array}$ & $\begin{array}{c}\text { Index of } \\
\text { Regional } \\
\text { Per cent } \\
\text { of } \\
\text { National }\end{array}$ & $\begin{array}{l}\text { Regional } \\
\text { Per Capita } \\
\text { Income }\end{array}$ & $\begin{array}{c}\text { Regional } \\
\text { Per Capita } \\
\text { as Per } \\
\text { cent of } \\
\text { National } \\
\text { Per Capita }\end{array}$ & $\begin{array}{c}\text { Index of } \\
\text { Regional } \\
\text { Per Capita } \\
\text { as Per cent } \\
\text { of National } \\
\text { Per Capita }\end{array}$ \\
\hline 1929 & 2,094 & 2.53 & 93.6 & 570 & 84 & 95.5 \\
\hline I 930 & 1,842 & $2.5^{I}$ & 92.8 & 497 & 83 & $94 \cdot 3$ \\
\hline I 93 I & I, 505 & 2.43 & 89.9 & 405 & $8 I$ & 92.1 \\
\hline I 932 & I, I I 5 & 2.35 & 86.9 & 300 & 79 & 89.8 \\
\hline I 933 & I , I I 4 & $2.4 \mathrm{I}$ & 89.1 & 299 & $8 I$ & $9^{2 . I}$ \\
\hline I 934 & I,345 & 2.54 & 93.9 & 360 & 86 & 97.7 \\
\hline I 935 & 1,527 & $2.6 \mathrm{I}$ & 96.5 & 408 & 89 & IOI.I \\
\hline I $93^{6}$ & I , 8 I 4 & 2.67 & 98.7 & $46 I$ & 87 & 98.9 \\
\hline 1937 & I,975 & 2.74 & IOI.3 & 494 & 88 & 100.0 \\
\hline I $93^{8}$ & I, 8 I 8 & 2.75 & 101.7 & $45^{\circ}$ & 88 & I 00.0 \\
\hline I 939 & $\mathbf{I}, 93^{8}$ & 2.75 & 101.7 & 473 & 88 & I 00.0 \\
\hline I 940 & 2,077 & 2.74 & IOI.3 & 499 & 87 & 98.9 \\
\hline I 94 I & 2,464 & 2.67 & 98.7 & 594 & 86 & 97.7 \\
\hline I 942 & 3,578 & 3.07 & I 13.5 & 862 & 99 & I 12.5 \\
\hline I 943 & 4,247 & 3.03 & I I 2.I & 962 & $9^{2}$ & I 04.6 \\
\hline I 944 & 4,372 & 2.89 & I 06.9 & I, 009 & 88 & I 00.0 \\
\hline I 945 & 4,539 & 2.92 & I 08.0 & $\mathrm{I}, 064$ & 90 & I 02.3 \\
\hline I 946 & 5,054 & 2.95 & IOg.I & I , I 79 & 97 & I 10.2 \\
\hline I 947 & 5,889 & 3.10 & I I 4.6 & $\mathrm{I}, 34^{1}$ & I 01.3 & I I 5.1 \\
\hline I 948 & 6,354 & 3.08 & I 10.4 & I,355 & 96.I & I 09.2 \\
\hline
\end{tabular}

Equation for Regional Total trend: $y=1.354 x+100.54$

Equation for Regional Per Capita trend: $y=.9609 x+100.15$ Average $1935-39=100$

Source: Income and Population data from which the above are derived may be found in United States Bureau of the Census: Statistical Abstract of the United States: 1939 and 1947 (Washington, D. C., United States Government Printing Office, 1940 and 1947); Survey of Current Business, 28:18-9, Tables 6 and 7, August, I 948; and United States Bureau of the Census: Series P-25, No. 12 
total regional income payments. Thus Chart 3 shows that, for the period as a whole, the relative growth of the incomeproducing power of the Mountain West was not accompanied by an equally great improvement in the economic position of the individual citizen of the region. Furthermore, it should be realized that the relative decline in population in the region tends to raise its per capita income figure by (statistically) dividing the income produced among fewer individuals. Consequently, it would seem that the per capita income status of the Mountain West would require some explanation.

An explanation is even more strongly called for when it is seen that other regions have been experiencing a more rapid rise in per capita income, particularly since 1940. Moreover, the absolute differences in dollar per capita income have widened rather than narrowed under the impact of inflation. This is clearly shown in Chart 4 which measures changes in regional per capita incomes in dollars between the "selected years" of 1940 and $194^{6}$ for the various census divisions of the United States. During this period the Mountain West reduced its inferiority to the national average per capita income from $\$ 75$ per person to $\$ 41$. The New England region, which registered the smallest percentage gain, also lost in terms of dollars as compared with the national average. New England enjoyed a per capita income in 1940 which was $\$ 15^{\circ}$ in excess of the national average, but by 1946 the difference had been narrowed to $\$ 120$.

By contrast the Middle Atlantic States, which increased per capita income by only $9^{1}$ per cent between $194^{\circ}$ and 1946 , a gain of 18 per cent less than the national average, nevertheless made a strong gain in absolute terms. In 1940 residents of this area received $\$ 194$ more than the national average, and by 1946 they were receiving $\$ 270$ per person more than the average American. Residents of the Pacific States, too, appear to be in a better position in 1946 than in 
1940. Here per capita incomes in 1940 exceeded the national average by $\$ 174$, and in 1946 by $\$ 262$.

At the other end of the scale the East South Central division made by far the greatest percentage increase during the war due to the extremely small base from which it is measured. Yet in absolute terms there was a greater difference

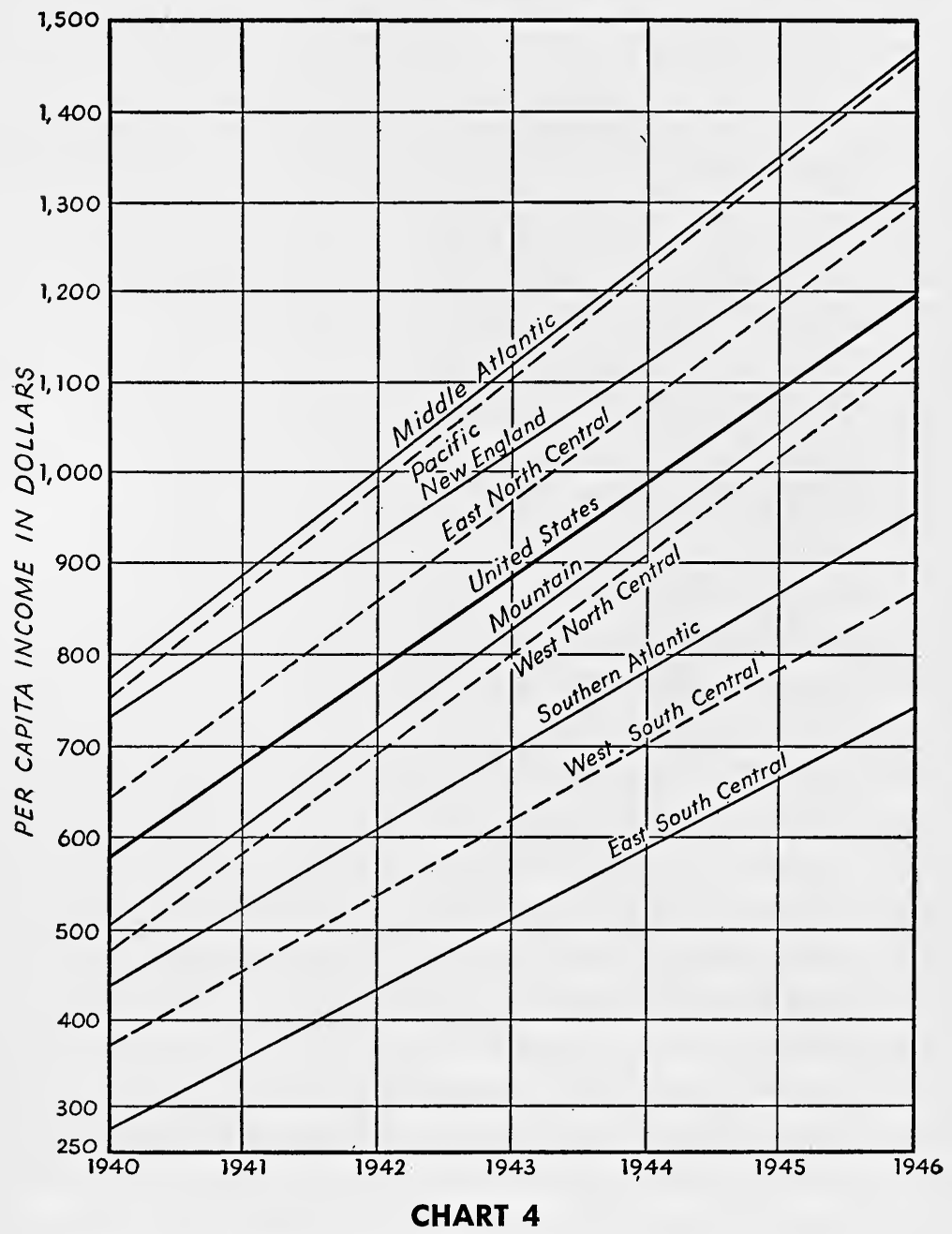

Changes in Regional Per Capita Incomes: 1940-1946 
in per capita income in this region and the nation as a whole in 1946 than there was in 1940. In 1946 the per capita income in these states was $\$ 459$ below the national average as compared with $\$ 297$ in 1940 . It may be gratifying to the citizens of the Mountain West and other low-income regions to realize that the relative differences in per capita incomes in the various regions have been narrowing, but they are uncomfortably aware that the absolute differences in dollars actually available for expenditures remain significantly large from region to region.

\section{Sources of Income}

It is generally understood that regional income disparities in the United States can be attributed in large part to differences in the type and balance of economic activities in the various regions. In general, manufacturing is more productive of income than agriculture, and low per capita income tends to be associated with a heavy emphasis on agriculture in a particular state or region. ${ }^{3}$ The four major sources of income payments in the United States are: (1) trade and services; (2) manufacturing; (3) government payments; and (4) agriculture, in that order. In the Mountain West, however, the trade and service category is followed by government and then by agriculture, with manufacturing pay rolls trailing as a poor fourth.

In Table 7 the major sources of income payments are shown for 1940 and $194^{6}$ for the eight states of the Mountain West, and for five other states selected for comparison. A study of this table reveals a number of significant facts.

Column 1 of Table 7 indicates clearly the small percentage of total income derived from manufacturing in the

${ }^{3}$ See Chapter 11, below. 


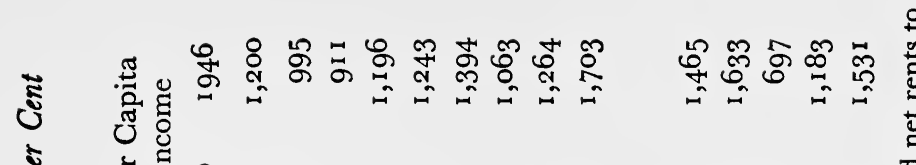

돈

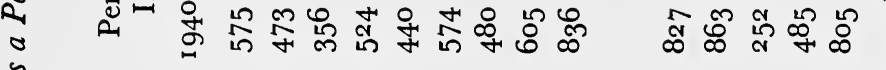

๖

हूँ

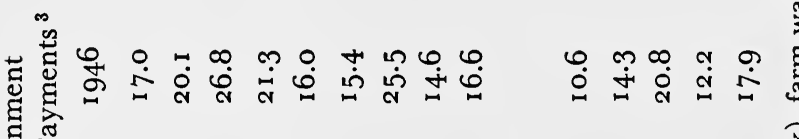

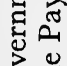

ปับ

ச

का है

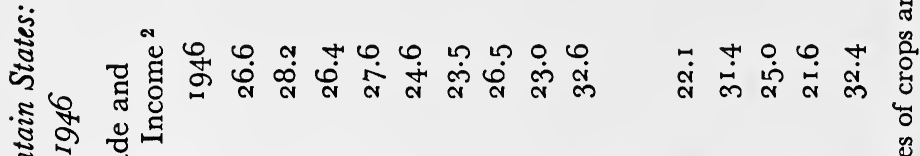

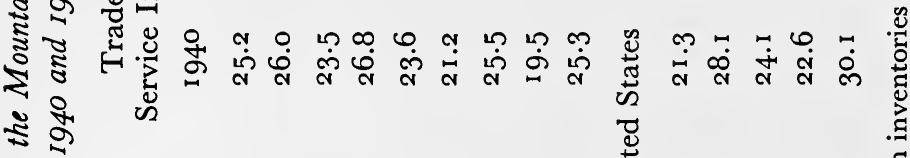

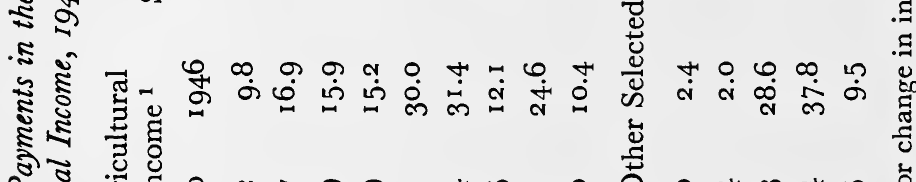

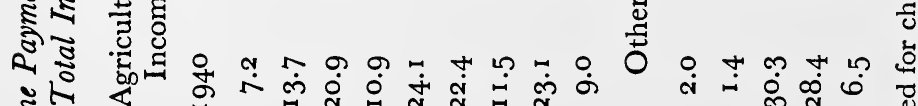

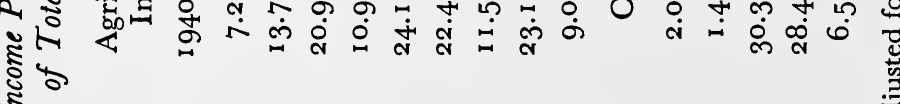

s

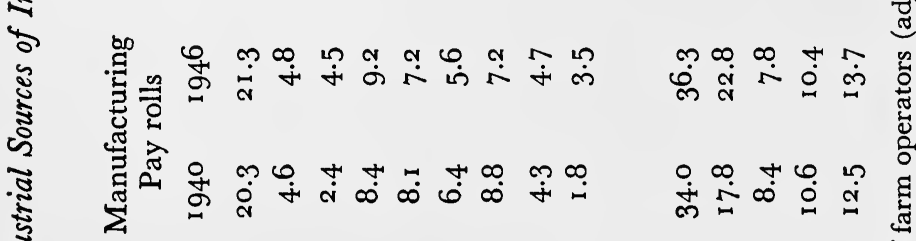

莺

क्ष

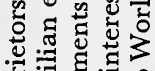

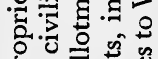

ลักี สี

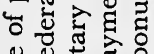

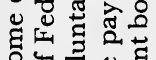

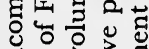

.

สี ฮี

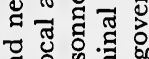

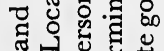

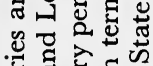

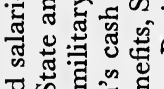

o

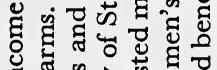

.

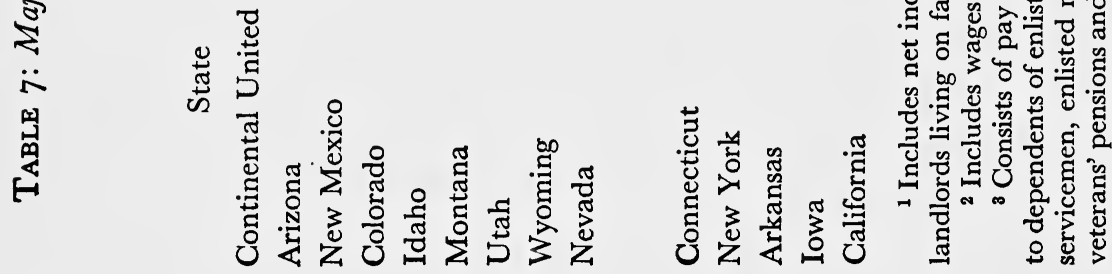

ठี 
Mountain region as compared with the national average. In the Continental United States in 1940, manufacturing payrolls accounted for 20.3 per cent of total income. In the Mountain States, Utah derived the largest percentage of total income from this source in 1940, and this amounted to only 8.8 per cent. Nevada, the least-industrialized of the Mountain States, received only 1.8 per cent of its total from manufacturing payrolls in that year.

In 1940 the Mountain States ranked in the following order in the percentage of total income derived from manufacturing: Utah, Colorado, Idaho, Montana, Arizona, Wyoming, New Mexico, and Nevada. These percentages for each of the states are given in Column 1 of Table 7. For comparative purposes five other states have been included. Connecticut, in 1940, received over one-third of its total income from manufacturing payrolls. New York derived nearly 18 per cent from this source, and even agricultural Iowa received a greater part of its income from manufacturing in this year than any of the Mountain States. California, with its highly diversified economy, relied upon manufacturing payrolls for 12.5 per cent of total income, and Arkansas received 8.4 per cent of its income from this source-the same percentage as Colorado. Thus we see that manufacturing payrolls bulk large in the income of high per capita income states such as New York and Connecticut. Even in so-called agricultural states as divergent in general character as Iowa and Arkansas, manufacturing is more important as a source of income than in the Mountain West.

Although manufacturing is less important as a source of income in the Mountain States than in the nation at large, the situation is reversed when we turn to agricultural income. In both $194^{\circ}$ and 1946 this source of income was more important to the Mountain States than to the nation as a whole. In the Continental United States in 1940, only 7.2 
per cent of total income payments was derived from agriculture, and despite the agricultural boom that accompanied the war only 9.8 per cent of total income was derived from this source in 1946 . In the Mountain States agriculture accounts for $15^{-25}$ per cent of total income payments. Only one Mountain state, New Mexico, received less income from agriculture as a percentage of total income in 1946 than in 1940, although actually agricultural income in this state increased by almost 112 per cent between 1939 and 1946. The decreasing dependence of New Mexico upon agriculture is explained by its increased dependence upon government as a source of income.

In the Continental United States, trade and service payments constituted the single most important source of income in both 1940 and 1946 . In the former year 25.2 per cent of total income payments came from this source, and by 1946 this share had risen to 26.6 per cent. In the Mountain region, too, trade and service payments are more important than any other single component of total income. With the exception of Wyoming, which received only 19.5 per cent of its income from trade and service in 1940, the Mountain States deviate only slightly from the national average. In that year, Colorado relied most upon trade and service, followed closely by Arizona, Utah, and Nevada, in that order. All of these states exceeded the national average, ranging from 26.8 per cent in Colorado to 25.3 per cent in Nevada. The remaining four Mountain States received less than the national average in 1940. Idaho received 23.6 per cent and New Mexico 23.5 per cent, while Montana received only 21.2 per cent from trade and service. Despite the dependence of the Mountain States upon the "tourist trade," and therefore upon trade and service income, we see that both California and New York received a larger percentage of their total income from this source in 1940 than did any of the Mountain States. 
Government income payments rival the importance of agricultural income in the Mountain States. There appears to be a rough inverse correlation between the importance of agriculture and government as source of income in the various states in the region. That is, those states which receive a relatively large share of their income from agriculture receive a smaller percentage share from government than those states which receive a smaller share of total income from agriculture. Nevada, however, is an exception to this generalization.

Twelve and four-tenths per cent of total income payments in the United States came from government sources in 1940. This component of income includes federal, state, and local government payments. During the war, of course, such payments increased more, in relative terms, than the other three components already examined, and by 1946 constituted 17 per cent of total income payments in the nation as a whole. The greatest increase came in federal payments.

In 1940 each of the Mountain States received a larger percentage of total income from government than the United States average. Arizona, one of the Mountain States least dependent upon agriculture in 1940, received the largest proportion of total income from government, this share amounting to 18.6 per cent. The next largest recipient of government income, proportional to total income, was Colorado which received 17.6 per cent from this source.

By 1946 New Mexico, which had ranked fourth in the Mountain States in dependence upon government in 1940, was most dependent upon this source and had made the largest percentage gain. Twenty-six and eight-tenths per cent of New Mexico's total income came from government in that year. Military installations and the important Los Alamos atomic bomb project undoubtedly account for this significant shift, because it is unlikely that state and local payments could have had such an influence. The remaining four Moun- 
tain States all received a smaller share of total income from government in 1946 than the national average, although all but one-Wyoming-show an increase in this component of income.

Compared with the other selected states included in Table 7, government income was still more important in the Mountain Region in 1946 than in most of these states. ${ }^{4}$ It is true that Arkansas made important gains, due in large part to huge military expenditures in this and other Southern states; and California received slightly more than the national average in 1946. All of these states, however, rely more on other sources of income than they do upon government. At least one Mountain state, New Mexico, derived a greater share of its total income from government than from any other source in 1946 .

The importance of government income payments to the Mountain region is apparent from these comments. To illustrate this point further, a comparison of private and government income payments alone can be made. Throughout the discussion immediately above, and in Table 7, agricultural income has included government payments to farmers. Thus, the full importance of the government as a source of income is somewhat minimized; in agriculture such items as soil conservation and crop subsidy payments are included in what is normally considered private income. It is possible to make a comparison of the relative importance of private and government income payments in which all government payments, including those made to farmers, are considered together and related to private income payments. This has been done in Table 8 , in which government payments consist of those components noted in footnote 3 of Table 7 plus government payments to farmers, while private income payments

${ }^{4}$ To compare the relative importance of government payments in the Mountain States and all other states see Survey of Current Business, 27:13, August, 1947, Table 4, Column 4. 


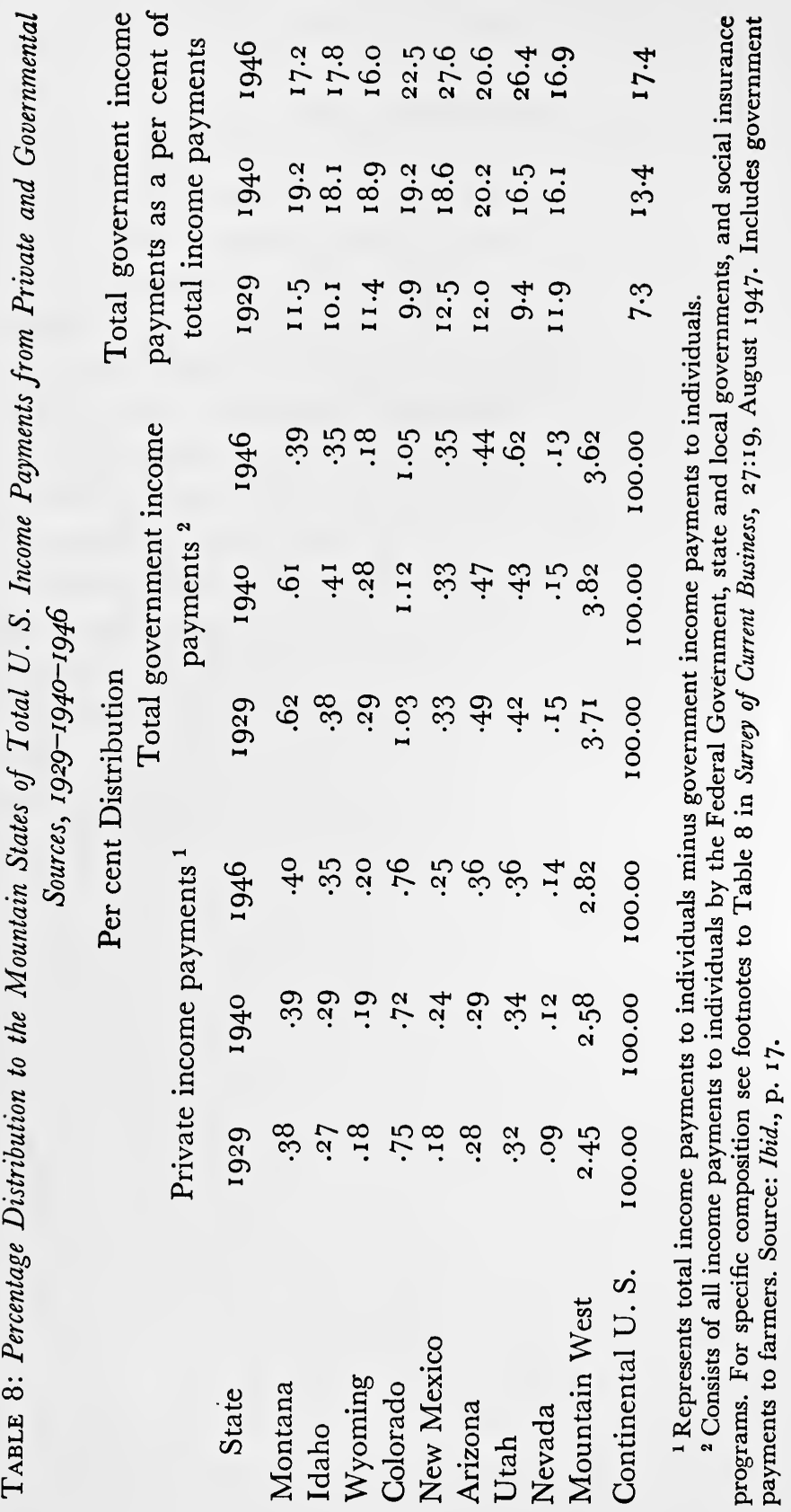


represent total income payments minus all government payments to individuals. The result of this reclassification of payments, lumping all government payments together, is to show that such payments are even more important to the Mountain region than the preceding discussion and Table 7 indicate. In order to show a long-term trend, private and government payments from 1929 to 1946 are given in Table 8 .

In 1929 private income payments in the Mountain States amounted to 2.45 per cent of the total of such payments in the Continental United States. By 1940 this share had increased to $2.5^{8}$ per cent, and by 1946 to 2.82 per cent. Thus the private sector of the Mountain economy has expanded, although by a relatively small percentage, in comparison with other regions in the country. Government payments did not follow a similar trend. Between 1929 and 1940 government payments in the Mountain States as a percentage of total expenditures of this sort in the United States expanded; from 1940 to 1946 the percentage declined slightly. In 1929 the Mountain region received 3.71 per cent of total government payments in the United States, and by 1940 this share had increased to 3.82 per cent. By 1946 this percentage had declined to 3.62 , a level below that of 1929 . It must be emphasized that this shift does not represent a net decline in such payments in absolute terms, but only that private income increased at a faster rate than government payments between 1940 and 1946. Despite the slight decline, the Mountain region still received a larger percentage of total government payments in the United States in 1946 than it did of total private payments. Moreover, government payments have been a more important source of income in all eight of the Mountain States than in the United States on the average ever since 1929, which is as far back as our data go. The significance of these facts will be discussed in Chapter 12. 


\section{Variations in Per Capita Income Among States of the Mountain West}

Although the Mountain West exhibits many elements of economic homogeneity, variations in per capita income among the eight states are significantly large. Five of the states cluster rather closely together in the size of income per person, but the other three diverge substantially from the five. In 1946 the variations in per capita incomes in Colorado, Idaho, Utah, Montana, and Wyoming fell between $\$ 1,063$ and $\$ 1,264$ (Table 7). In Arizona and New Mexico per capita incomes were $\$ 995$ and $\$ 911$ respectively. In most years the per capita incomes in these two states are lower than in the others. On the other hand income per head in Nevada is consistently well above that of the other states. In 1946 it was $\$ 1,703$ which was even higher than in the wealthy states of New York and California.

The special factors which cause these departures from the regional norm are reasonably apparent. In New Mexico and Arizona the presence of large, under-privileged, minority groups is the primary cause of low per capita income. The income of the Indians is very low for the cultural and economic reasons which were explained in Chapter 7. The Spanish-Americans also display a concentration in low-paid industrial and agricultural employments.

The origin of the high per capita income of Nevada is less easily explained. Several factors certainly contribute to it, but the difficulty lies in assessing the quantitative importance of any one of them. Agriculture in the state is mostly large-scale cattle and sheep ranching which usually earns high incomes for the small number of persons engaged in it. Mining is very important in the state and it is a high-wage industry there. Probably even more significant, although less 
demonstrable, is the effect on the incomes of residents of the state of the reputedly high returns of the well-known recreation industry of Reno and Las Vegas. Also, Nevada does not levy state income and inheritance taxes, and, because the total population of the state is very small, this fact probably raises the size of average income reported by individuals filing Federal Income Tax returns in Nevada.

In all three states the divergences of per capita incomes from the regional norm is at least as well explained by the cultural peculiarities of these states as by the more prosaic factors usually emphasized by the economist.

\section{The Stability of Incomes in the Mountain West}

Since the war the Mountain West has experienced a period of prosperity in which all economic groups have shared. High levels of employment and productivity have been reflected in rising levels of income. Some agents of production have gained more than others, but the income position of this region is stronger than it has been at any time since records were available. How stable is the present income position of the Mountain States? What is the probability that present incomes will remain at the post-war level?

The agricultural sector of the Mountain economy has expanded more than other sectors between 1940 and 1949. Further, although government expenditures were slightly less important after the war than they were in 1940 as compared with total incomes, this source of payments in the Mountain States is still a very important one. Thus, the stability of incomes in this region is largely dependent upon two factors. First, of course, is a continued high level of effective demand for farm products and, second, whether government policy will maintain a high level of public expenditures. 
Agricultural prices, in common with other raw material prices, frequently have been subject to sudden and sometimes violent fluctuations. Any region which depends upon agricultural incomes to a large extent is bound to have a less stable income position than a region with a widely diversified economy. We now know that 1948 turned out to be the peak year of the post-war boom in farm income. Consequently the Mountain West can expect to witness a decline in total income payments - a reversal of the trend which raised these payments to a point slightly above the national average in 1947 .

It is not meant to imply that a crash similar to that of the early 2o's is in prospect for agriculture. Circumstances following World War II differ in many important respects from those existing after World War I. Guaranteed farm prices seem to be assured at least for the immediate future. In addition, as long as urban employment remains high, the demand for farm products will remain relatively strong. Nevertheless, when farm prices turn downward-and there is little question that they eventually will-the Mountain West and the Great Plains regions will be among the hardest hit in the United States, and per capita incomes in most of the eight states may decline to their post-war position-well below the national average.

In the second place, the Mountain West cannot maintain its 1948-9 income without a substantial volume of government expenditures in the region. A cut in such expenditures would have serious effects on the economy of the West. Not only would some primary unemployment result, but secondary unemployment arising out of the curtailed purchasing power of the region's residents would be engendered. Not only would the public sector of the regional economy be affected, but unemployment means declining incomes for the individual and for the region. 
Scattered throughout the Mountain States are dozens of "ghost towns"-former mining camps-that offer mute testimony to the instability of an undiversified economy. Such towns were dependent for their incomes upon the production of silver and gold. When the mining of these metals was no longer profitable or feasible, the population quickly migrated to other towns or to other regions. The analogy here is obviously exaggerated. The economy of the Mountain States is not as simple as that of the early mining camps. But the lesson we can learn from these early failures to diversify production is clear. If we are to maintain our present levels of income and to raise them as production expands, we must learn not to depend too heavily upon any one type of productive activity. 


\section{Chapter 11. Productivity}

Income per capita in the Mountain West is low relative to the industrial East and the Far West, as we have seen in the preceding chapter. Why? Is it because the region is relatively inefficient as an economic organization? Is the productivity of its workers low? Or is the region an undeveloped "colonial" dependency of the older, established East?

These are difficult questions to which there is no easy answer. The structure and functions of the American economy are too complex and too dynamic in character for glib generalizations. At the same time there are facts about the regional and national economies which can be established and which do lead logically to certain conclusions.

It is now generally agreed that a close relationship exists between the occupational pattern of a regional or national economy and the level of its per capita income. ${ }^{1}$ Wherever a large proportion of the labor force is engaged in the pri-

${ }^{1}$ See Colin Clark: Conditions of Economic Progress (New York, The Macmillan Company, 1940), and Louis H. Bean: "International Industrialization and Per Capita Income," in Studies in Income and Wealth. Vol. VIII (New York, National Bureau of Economic Research, 1946), pp. 119-143. 
mary occupations of agriculture, forestry, and fishing, per capita incomes are low. However, as industrialization progresses and the relative amount of employment in the secondary occupations-mining, manufacturing, and constructionrises, per capita income payments also rise. Finally, as the economy makes greater and greater use of mechanical power in production, the manpower released from primary and secondary employments tends to move into the tertiary occupations-trade, service, communications, the professions, and so forth. Only a highly productive economy can enjoy a high per capita income while supporting a large percentage of its labor force in the "luxury" occupations. Thus, it appears that the occupational distribution of the labor force and the stage of economic development of an economy serve to explain, in large part, the relative level of the per capita income of its members.

When we apply this line of reasoning to the economy of the Mountain West and compare the regional occupation pattern with that of the nation as a whole, some very interesting contrasts are revealed. A glance at Chart 5 and Table 9 shows that the American economy has been going through the characteristic evolution of a modern industrial society. Over the decades the preponderance of total employment has shifted successively from agriculture, to manufacturing, to trade and service occupations.

In $\mathbf{1 8 8 0}$, in the nation as a whole, 51.8 per cent of the labor force was engaged in the primary occupations. By 1940 only 18.7 per cent was so engaged. During the last seventy years the proportion of the labor force in tertiary employment has increased steadily, while employment in the secondary occupations also has increased.

In the nation as a whole, per capita incomes also have risen steadily as a larger and larger share of the working population has been shifted from primary to secondary and 

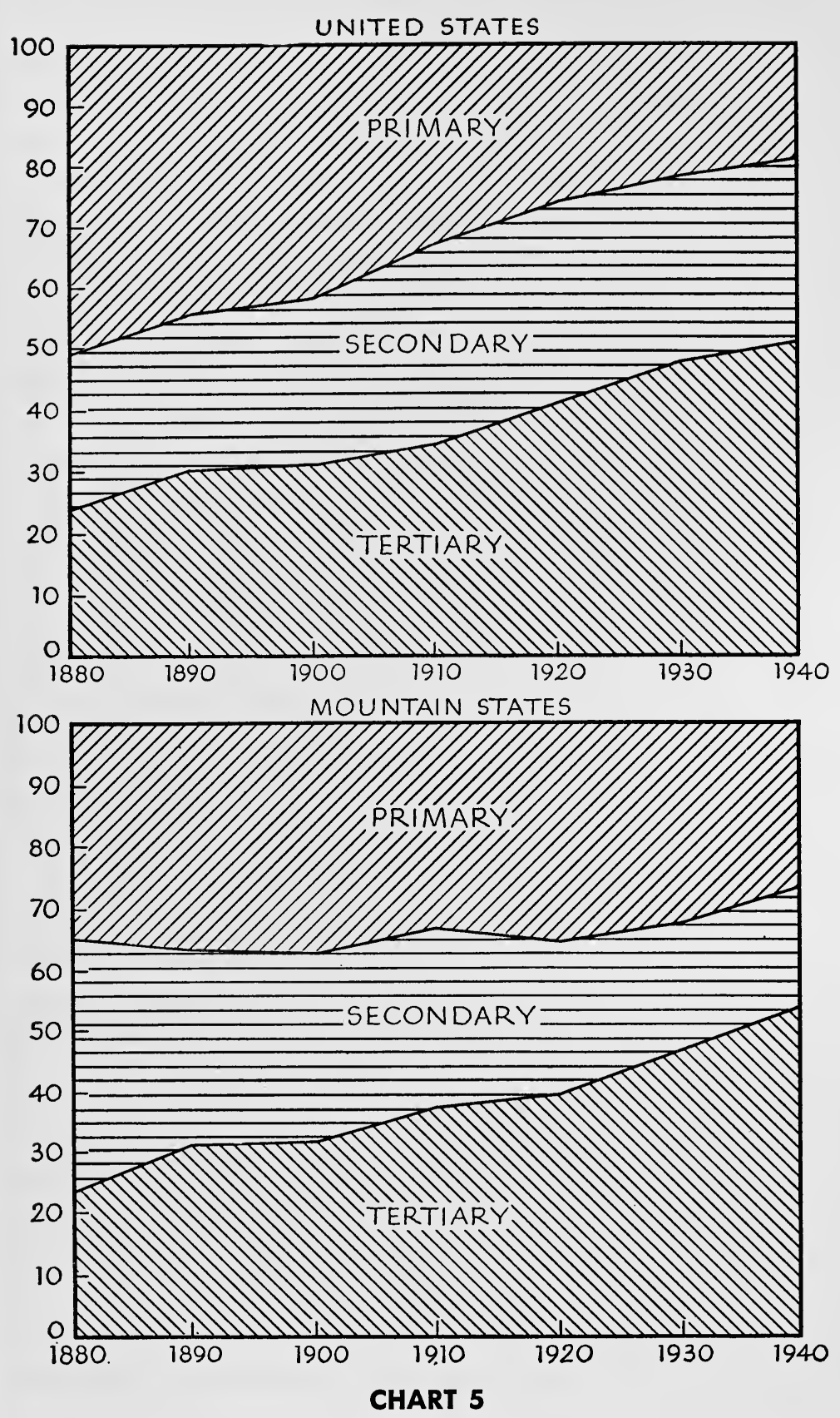

Occupational Patterns in the Mountain West and U. S.: 1880-1940 Per cent of Total Employed 
tertiary occupations. ${ }^{2}$ Of course other forces were at work in the economy during this period which contributed to the upward trend in money incomes. Nevertheless, the shift to higher forms of employment undoubtedly has been a factor in the secular rise in per capita incomes in this country.

TABle 9: Occupational Patterns in the Mountain West and United States. $1880-1940$

United States

Year

I 880

I 890

1900

I 910

1920

1930

I 940 Primary Secondary Tertiary 5 I. 8 43.6

42.0

33.2

26.5

22.0

I 8.7

$$
25.1
$$$$
26.8
$$$$
27.0
$$$$
30.0
$$$$
33.2
$$$$
30.4
$$

30.0
23. I

29.6

31.0

36.8

40.3

47.6

$5^{1.2}$
Mountain States Primary Secondary Tertiary

$\begin{array}{lll}34.8 & 4 \mathrm{I} \cdot 4 & 24 . \mathrm{I} \\ 35.5 & 3^{2.3} & 3^{2.2} \\ 36.6 & 3 \mathrm{I} .4 & 3^{2.0} \\ 32.7 & 28.7 & 3^{8.6} \\ 34.5 & 25.5 & 40.0 \\ 3 \mathrm{I} .8 & 20.7 & 47.5 \\ 26.3 & 20 . \mathrm{I} & 53.6\end{array}$

Source: United States Bureau of the Census, Tenth through Sixteenth Census: Population Reports. In order to adhere to the Clark classification, some reclassification of the Census data was necessary. This, in turn, required that some estimates be made for the first three decades of the period under consideration. In the Twelfth and earlier Census reports, "general laborers" are not divided according to industry. A rough ratio of this division was computed for the period $1910-40$, and this ratio projected backwards to the period I880-1910.

The occupation pattern of the Mountain West provides a striking contrast to the national pattern. In 1880 the largest proportion of the labor force of the Mountain West was not found in agriculture, but in the secondary occupationsmainly, of course, in mining. The proportion of employment in this category has declined steadily ever since, however, so that by 1940 the Mountain West employed only 20 per cent of its labor force in manufacturing, mining, and construc-

2 Simon Kuznets: National Income: A Summary of Findings (New York, National Bureau of Economic Research, 1946), p. 32. 
tion, as compared with 30 per cent similarly employed in the national labor force.

The rise in secondary employment in the nation as a whole has been due to the increasing importance of manufacturing. Mining has never been a major occupation in the nation. On the average only slightly more than 2 per cent of the total labor force has been engaged in mining, and this share has remained relatively constant throughout the entire period from 1880 to $1940 .^{3}$ During this same period, the proportion of workers engaged in manufacturing rose from 19.2 per cent to 26.4 per cent of the labor force.

The decline in the importance of secondary employment in the Mountain States has been due to a decline in both manufacturing and mining. In $1880,20.4$ per cent of all workers in the Mountain States were employed in mining, while 16 per cent were engaged in manufacturing. By $194^{\circ}$ only 6.4 per cent of the labor force in the region was employed in mining, and 8.4 per cent in manufacturing. The trends in employment in mining and manufacturing, for each of the Mountain States, as well as regional and national averages, are given in Table 21 at the end of this volume.

The proportion of employment in agriculture and forestry in the Mountain West remained quite stable from 1880 to 1920. Roughly one-third of the labor force was in the primary occupations. It is only in the last two decades that a relative shift from agriculture has begun. For the nation as a whole this shift has been a constant one since before 1880 . Consequently, the economy of the Mountain West is still orientated toward the primary occupations when compared with the nation as a whole. This is, in all probability, a basic factor in the relatively low per capita income of the Mountain West.

3 It must be remembered that this discussion is in terms of shares of the total labor force, or percentages. In absolute terms, the number of workers employed in mining has more than doubled during the period. 
The percentage of the labor force of the Mountain West employed in tertiary occupations has been slightly larger than the corresponding per cent for the United States since 1880. It is somewhat surprising that the relative difference is not greater. The geographic location and expanse of the Mountain West have brought about a development of (transcontinental) transportation and communication facilities disproportionately large for the needs of the regional population. The basic retail and wholesale trade facilities required to serve adequately a sparsely populated area have overemphasized the relative importance of these occupations. The same can be said of the service occupations, especially when the tourist industry is as important as in this particular region.

The direct effect on income of the Mountain West's concentration of employment in tertiary occupations is not clear. Perhaps there is none. Probably this concentration helps to offset the depressing effect on incomes of the preponderance of the primary occupations. On balance, the over-emphasis on agriculture, and the consequent squeezing of secondary employment between the upper and nether millstones of primary and tertiary employments is a major reason for low per capita income in the Mountain West.

\section{Productivity in Agriculture and Manufacturing}

The relatively lower productiveness of the regional economy which results from the concentration of employment in low income occupations is consistent with the relatively low per capita income of the region; but when we look at the related, but distinct, concept of productivity we find a striking inconsistency. The relative productivity of most of the workers of the Mountain West is high even though per capita incomes are low. 
The existing information which bears on this point demonstrates that productivity in both agriculture and manufacturing is substantially higher in the Mountain West than in the United States as a whole. The data show that, measured over the entire period, 1880 to $194^{\circ}$, manufacturing productivity in the Mountain West is 29 per cent greater than the national average. Also, output per worker in agriculture in the region has been roughly 22 per cent greater than the national average during the period 1879 to 1939 .

These are startling figures, and it is desirable to present the data and analysis from which they are derived in some detail.

\section{Output per Worker in Agriculture}

Output per worker in agriculture may be measured by dividing the "value of product" of agriculture in the region and nation by the number of workers in agriculture. The results of this procedure expressed in constant dollars are given in Table 10 below:

TABle 10: Output per Head in Agriculture, 1878-1939 (in Constant Dollars)

Mountain West as per cent of

Year

Mountain West United States United States

1879

1889

1899

1909

1919

1929

1939

$\$ 318$
371
I,063
I, 336
I,6 10
I,760
I, 926

$\$ 421$

443

756

$75 \cdot 5$

$83 \cdot 5$

140.5

133.0

I I I .0

I,453

I 59.0

1,212

158.5

SourcE: Basic data Twelfth through Sixteenth Census of Agriculture.

Until 1889 the average farm worker in the Mountain States produced less, in terms of value, than the average farm 
worker in the nation. But in the decade 1889 to 1899 his output increased sharply, passing the national average by $\$ 307$, or an amount almost equal to total output in 1879 . Since then agricultural productivity in the Mountain States has remained higher than the national average.

Despite the crudeness of this measure of productivity there is little reason to doubt its validity. The findings of Ducoff and Hagood for 1939 lead to the same conclusions concerning the relatively greater output per man in the Mountain States than in the nation as a whole. Only one region, the Pacific region, shows a greater gross or net return per farm worker than the Mountain States. ${ }^{4}$

The greater increase in output per agricultural worker in the Mountain West than in the nation might be thought somewhat surprising in view of the fact that mechanization in the region has not increased at as fast a rate as it has in the nation as a whole. The changes in mechanization in the United States since 1920 are fairly well indicated by changes in the number of tractors on farms. ${ }^{5}$ In 1920 the Mountain States were above the national average in tractor-mechanization, but by 1940 the region had fallen substantially below the national average. From 1940 to 1945 mechanization increased at a rapid rate both in the Mountain West and elsewhere, but the region continued to lag behind the nation. ${ }^{6}$ In terms of total equipment per worker, the Mountain States stand substantially above the national average and are very markedly superior to the South. On the other hand, the central farming areas of the United States are more highly mechanized than the Mountain West. ${ }^{7}$

But such measures of capital investment tell only part of

4 Ducoff and Hagood, op. cit., Chapter 4.

${ }^{5}$ United States Department of Agriculture: Progress of Farm Mechanization. Miscellaneous Publication No. 630 (Washington, D. C., October 1947).

6 Ibid., p. 45.

'Ibid., p. 12. 
the story, at least as far as the Mountain West is concerned. The rapid rise in productivity in agriculture in the West has taken place simultaneously with the investment of hundreds of millions of dollars in irrigation works, both public and private. Irrigated agriculture, we noted in Chapter 4, is characterized by large yields per acre of high value crops. From this point of view, capital investment, if not mechanization in a narrow sense, certainly has been very heavy in Western agriculture. Thus, the high productivity of Western agriculture must be attributed to the heavy capital investment per worker as well as to the natural factors of climate and soil fertility. Moreover, it is highly probable that further mechanization will bring about even greater productivity in Western agriculture. The present experiences of the beet sugar industry, described in Chapter 15 clearly foreshadow such a trend.

\section{Productivity in Manufacturing}

Manufacturing has been a secondary type of economic activity in the Mountain West throughout the region's development. Nevertheless, productivity in manufacturing, as measured by value added per worker, has been high. For most of the time since 1880 manufacturing productivity in the region has exceeded national productivity by a substantial margin, as we may see in Table 11 immediately below.

Any comparison of manufacturing productivity in the Mountain West and in the nation should not overlook the fact that productivity in the region has not been increasing over time as rapidly as national productivity. The general trend in the United States has been upward. Except for a slight decline between 1889 and 1909 , output per worker has been increasing. In the Mountain region, too, productivity 
TABLE I I: Output per Head in Manufacturing ${ }^{8}$

(in Constant Dollars)

Mountain West as per cent of

Year

I 880

1890

1899

1909

1919

1929

I939
Mountain West United States

$\$ 1,579$

2,367

3,294

2,638

2,073

3,801

5, I 5 I
$\$$ I, I I I

I, 768

I,985

I,9 I 7

2,94 I

3,847

4,064
United States

142

I 34

I 66

I 38

IOI

99

I 26

Source: Basic data from Census of Manufactures (1 oth through 16 th Census).

was rising until 1899 , but the decline that set in then lasted a decade longer in the region than in the nation, and by 1919 productivity in the region was only $3^{1}$ per cent above the level of 1880 , while in the nation as a whole output per worker was 84 per cent above 1880 .

Even if we allow for some error, since all of the statistical material used is not completely reliable, it appears that in the Mountain West output per head in manufacturing has not increased as fast as the national average between 1880 and 1940. These data seem to indicate that in this sphere of economic activity we of the West are not utilizing our resources, human and otherwise, as effectively as we were half a century ago.

The high per capita output of manufacturing workers

8 Value added by manufacturing divided by average number of workers for the corresponding year. Far better measures of productivity than this exist for the United States, of course; but since the purpose of the present study is to make a comparative analysis of productivity in the Mountain States and the nation, it was thought best to use indexes that were entirely comparable. There is a fairly close correlation between the index computed here for the United States and the much more elaborate and refined index of manufacturing output computed by Fabricant. This fact gives rise to some confidence in the reliability of the regional index. See Solomon Fabricant: The Output of Manufacturing Industries: 1899-1937 (New York, National Bureau of Economic Research, Inc., 1940). 
in the Mountain West has not been entirely unnoticed. Occasionally, the higher productivity of manufacturing workers in the Mountain West has been attributed to such factors as the superior intelligence, dexterity, initiative, and individualism of Western workers-or to the salubrious Western climate and the superior living conditions to be found in the region. ${ }^{9}$ There is some evidence that in specific cases the efficiency of the Western worker is high in relation to other workers. Output per worker in a large ammunition plant in Denver during the war was substantially higher than in similar plants in the East which were producing the same product, by the same processes, and using the same kinds of machinery. However, the abnormal factors in this situation-patriotic impulses, high wages, lack of previous factory background-make it dangerous to generalize from this particular case.

Moreover it is clear that productivity, as measured by output per worker, is influenced by other factors than the efficiency of the individual worker. A more reasonable explanation of the high productivity of manufacturing workers in the Mountain West is that the higher output per worker is largely the result of a higher investment of capital per worker in the region than in the nation as a whole. General observation of the nature of Western manufacturing supports this position. Manufacturing industry is not large to begin with; and much of that which does exist is concentrated in capital-using industries. Beet sugar refining, which is, perhaps, the most pervasive manufacturing industry of the region, has a high capital investment per worker. Steel production also is a capital-using industry; and, in 1939, these two industries were sufficiently important in the region to affect total manufacturing employment statistics appreciably.

${ }^{9}$ Denver Chamber of Commerce, Industrial Department: An Analysis of Reasons for the High Productivity of Denver Labor (Denver, Colo.: n.d.), p. 6. 


\section{Summary}

The measurement and explanation of the relative productivity of labor in different industries and different areas poses a number of extremely difficult statistical and conceptual problems. ${ }^{10}$ We know that productivity does vary from place to place, but we cannot measure the differences accurately nor explain them fully. Our conclusion has been that, as far as the Mountain States are concerned, the high output per worker in agriculture and manufacturing in the region is primarily the result of the high capital investment per worker which characterizes the major types of farming and manufacturing found in the region.

The relation of high worker productivity to the low per capita income of the region is not clear. The connection between these two phenomena is not a simple, direct relationship in any case. Low regional per capita income is partially a result of the general level of money wages and money prices; and we know that these vary from region to region. As long as economic immobilities exist, a high output per worker need not be associated with a high money wage in a particular region.

Our examination of the productivity of workers in the Mountain West does point to the conclusion that low per capita income in the region is not the result of the low productivity of the labor force. Fortunately for the region, the way to higher income is not barred by the low productivity of the region's workers.

The major conclusion of this chapter is that the most likely explanation of the low per capita income of the region

${ }^{10}$ See United States Department of Labor, Bureau of Labor Statistics: Summary of Proceedings of Conference on Productivity. Bulletin No. 913 (Washington, D. C., United States Government Printing Office, 1946), and H. W. Arndt: "Productivity in Manufacturing and Real Income Per Head in Great Britain and the United States," Oxford Economic Papers. No. 8 (Oxford, The Clarendon Press, 1947), p. 65. 
is the relative lack of productiveness which results from the less advanced pattern of employment in the region. Up to now the Mountain West has been too highly specialized in the extractive industries where the value of output and per capita incomes are low. Such an employment pattern is typical of the so-called "colonial" areas of the world.

These conclusions offer a strong argument for a policy of diversification in the economic structure of the Mountain West and for the achievements of a better balance among agriculture, manufacturing, and trade. As the occupation pattern of the region shifts in the direction of the national pattern, per capita income should approach or exceed the national average. At the same time there is every reason to improve the productivity of the worker of the region while increasing the region's productiveness. The Mountain West should be alert to accelerate the process of mechanization in existing industries and in agriculture as rapidly as possible. Also, in the establishment of new industries, such as shale oil and phosphate production, it should look forward to utilizing processes which require large amounts of capital equipment. The use of more mechanical power and more machinery in production opens a promising route toward the goals of higher output per worker and higher income per capita. 


\section{Chapter 12. A "Balance of Payments" for the Mountain West ${ }^{1}$}

The relatively low per capita income of the Mountain West apparently is not the result of the low productivity of labor in the region. It is, in part, due to the relative underdevelopment of the region which carries with it a relative lack of productiveness for the labor force as a whole. A regional economy which specializes in raw materials production does not add as much in value to its products per capita as does a region in which manufacturing is relatively important. Various studies have shown that the income and purchasing power of agricultural workers in the United States have been no more than one-third or one-half the size of the purchasing power of a manufacturing worker. ${ }^{2}$ Thus, the average producer in an agricultural region is required to spend two or three times as many days or hours of labor in order to buy

1 Much of the research upon which this chapter is based is the work of Professor J. Howard Craven of the Department of Economics, University of Wyoming. The few figures cited here are the end-product of many hours of laborious investigation of scattered, fragmentary data concerning the production, transportation, and consumption of various commodities important in the region.

2 Louis J. Ducoff: Wages of Agricultural Labor in the United States (Washington, D. C., United States Department of Agriculture, 1945), pp. $89-92$. 
as much as the average producer in a manufacturing region. In other words, when the Mountain West exchanges wheat and beef for automobiles, it does so on terms which reflect its own relatively low productiveness.

The exchange may have still other disadvantages. The bargaining power of the region may be limited by competition with other raw-materials-producing regions while its demand for the manufactures of other regions may be inelastic. When either of these conditions exists, the terms of trade may be unfavorable to the raw-materials-producing region. This has proved to be the case in numerous examples in international trade. ${ }^{3}$

Unfortunately, in the sphere of inter-regional trade the basic data for determining the character of inter-regional exchange do not exist. A balance of payments is needed. Such a balance sheet is a summary statement of all the transactions in commodities, services, securities, loans, and so forth, which take place between a given economic unit and all other economic units in the larger economy. In the field of international trade the compilation of a balance of payments is made possible by the fact that national governments exert a direct control over international business transactions and, in doing so, keep records of those transactions-custom duties on imports, export permits, exchange licenses, and so forth.

No such records exist within the United States for its various regional components. Although these regions are different enough to be as nearly distinctive economic units as the national states of Europe, we often speak of the United States as the "greatest free trade area in the world," and make little attempt to measure or record the multitude of business

${ }^{3}$ See John H. Williams: Argentine International Trade under Inconvertible Paper Money: 1880-190o. Harvard Economic Studies No. XXII (Cambridge, Mass., Harvard University Press, 1920); and Jacob Viner: Studies in the Theory of International Trade (New York, Harper and Brothers, 1937). Also Theodore W. Schultz: Agriculture in an Unstable Economy (New York, McGraw-Hill Book Company, Inc., 1945). 
transactions which are, in reality, inter-regional rather than domestic in character.

It is doubly unfortunate that data on regional transactions do not exist, for a balance of payments would do much to describe and explain the role of a regional economy in the national economy and show how the one complements the other. The Mountain West exports copper and gold and wheat and mountain scenery to the rest of the United States. It uses the proceeds to buy shirts and shoes and automobiles and refrigerators. This much is fairly obvious. But does it have any money left over; and, if so, what does it buy with the money-insurance or shares of A.T. \& T. or government bonds? Or, on the contrary, does the region go into debt on current account; and, if so, where does it borrow the money? A balance of payments for the Mountain West would answer these questions and many others. It would reveal the fundamental nature of the regional economy. It would establish the role of the economy in the national economic structure, and show what the region contributes to the nation and what it receives in turn.

The discussion which follows does not present a comprehensive balance of payments for the Mountain West. Lack of data makes this impossible. However, certain examples of items important for a balance of payments have been singled out for study. These items have been selected as representative of various important sectors of the regional economy. From these samples some idea of the over-all nature of the balance of payments problem may be gained, particularly when the indications gained from them can be linked up with other types of evidence from other sources.

It is recognized that the results obtained by this method are merely indicative of the over-all character of the balance of payments. It is very much like guessing at the pattern of wind behavior over a large area by selecting certain spots 
through the area and throwing straws into the air to determine the direction of wind movement and its force at those spots. Moreover, since only one year-1939-has been studied, the method relies on the straws to disclose the prevailing winds as well. To many, the method employed may not promise much. It is well, however, to remember that men knew a great deal about wind behavior long before the science of meteorology had been established. The study of "gross regional product" and regional commodity and financial flows is very young. Adequate measurement will develop only when it is recognized that such measurement is a useful and profitable means for the employment of the limited facilities for research.

\section{Exports of the Mountain West}

The great bulk of the exports of the Mountain West -in weight and value-takes the form of raw or semi-processed materials. Some foods ready for the ultimate consumer are exported. The export of manufactures is relatively unimportant in total, although some specialities, such as mining machinery, dominate the world market.

Of the commodity exports from the region, minerals are historically the most important. Most of the products of the mineral sector of the economy move in inter-regional trade on a net export basis. It is estimated that copper valued at $\$ 126$ million was produced in the region in 1939 , and that $\$ 116$ million of this was exported. This includes copper in the form of ore, concentrates, blister and cathodes as well as some manufactured products, such as wire. From coal and lignite, petroleum, gold, and silver production there was an estimated net export valued at approximately $\$ 15^{\circ}$ million. Lead, zinc, molybdenum, tungsten, and a host of other min- 
erals also moved out of the region to a greater extent than they were imported.

One of the exceptions to this general pattern is naturalgas and natural-gasoline. Although the value of domestically produced natural-gas and -gasoline was over $\$ 25$ million in 1939, the value of these products consumed within the region in that year exceeded \$3o million, necessitating a net import valued at over $\$ 5$ million.

In the case of many, if not most, of these exported minerals, the large mines and fabricating plants are owned by companies whose central offices are located outside the Mountain West. Under such circumstances, payments for these exports do not immediately move into the region where the exports originated. As a matter of fact, in a great number of cases ore and semi-finished products are shipped from company-owned mines and plants within the region to companyowned plants outside the region for further processing. The resulting processed goods may then be sold from outside plants to buyers located either outside or inside the region. In the former case, the portion of sales price representing the domestic ores and semi-finished products stays outside the region (initially, at least) whereas, in the latter case, payments are made from inside the region to the "outside" firms. In either case, the value of these exported goods is not matched by a corresponding import of money payment.

Ultimately, a flow of money into the region does take place. Payrolls covering company operations within the region are "imported." Funds for capital development of company property flow in, and dividend payments on shares of stock owned by residents of the region move across the regional boundaries from outside. Usually the bulk of the securities of outside companies is held outside the region. Consequently, something short of the full value of the exports flows into the region as payments. The difference, which is 
retained outside, is, of course, the return on previously imported capital which made possible the development of these particular mineral deposits. When all this is taken into account we find that in the mineral sector in 1939, payments into the region fell short of the net value of products exported to a significant extent. For the copper economy, for instance, out of an estimated value produced within the Mountain West of nearly $\$ 126$ million, money payments within the region were probably in the neighborhood of $\$ 86$ million. This means that from its net exports of \$116 million of copper the region failed to receive payment, as a region, for $\$ 30$ million.

Much the same can be said of the other metals so that we have here a substantial "leak" in the regional balance of payments. Residents of the region are unable to import consumer goods to the extent of these "retained" payments held outside. This is a concrete example of the reason for describing the Mountain West as a "colonial dependency of absentee owners." It is also another element in the explanation of the low per capita income of the residents of the Mountain West. It might be added that, in the field of policy, the situation described here helps to explain the adoption or advocacy by many Western states of a severance tax on natural resources.

Turning to agriculture, we find that the agricultural sector of the economy is also on a net export basis. The people of the Mountain West produce more agricultural products than they consume, exporting the surplus to other regions. Net exports of livestock and livestock products from the Mountain West in 1939 are estimated to have been valued at nearly $\$ 72$ million. The great bulk of these exports was composed of live cattle, calves, sheep, and lambs. Some meat and by-products from domestic slaughter were exported also. It is estimated that just under $\$ 30$ million worth of wool was exported from the region in 1939 . 
The probable 1939 export of wheat from the Mountain States was around $\$ 27$ million. In addition, over $\$ 17$ million of flour was produced by domestic mills in excess of that used by the domestic baking industry. No attempt has been made, however, to estimate the portion of this that was sold to resident housewives and the portion that moved in interregional trade.

In the case of agricultural commodities, in contrast to the minerals, the producing firms are mostly local in origin. Individual farmers and small domestic concerns are responsible for the larger part of the value produced in the region. To be sure, there are some branch offices of large "foreign" meat-packing and flour-milling firms in the region, but the relative value of payments retained outside on their account is probably not large. In the main, there probably is an influx of money payment corresponding to the net exports of the agricultural sector.

The exchange of services of various kinds across international boundaries constitutes a large part of international trade. Such exchanges are probably even more important in inter-regional trade since there are fewer barriers to surmount, and the regions are knit closely together. On the export side, the Mountain West is a major supplier of recreational services to the rest of the nation. Expenditures in the region by tourists for food, lodging, transportation, licenses, and equipment are very significant in the regional economy. A net balance in this sector of the economy provides the region with large sums which can be used to purchase the manufactures and services which the inhabitants of the region buy abroad. Unfortunately no trustworthy estimates of these expenditures are available. 


\section{Imports of the Mountain West}

The imports of the Mountain West fall into two broad categories-items not produced in the region and items produced domestically in appreciable quantity but requiring additional imports to fill consumer demands. Shoes and men's ready-made clothing belong in the former group; canned fruits and vegetables and candy are important examples of the second. In both cases, however, most of the imports are produced by firms whose central offices and plants are located outside the region. Very few of the significant items of import are produced in the external plants of domestic firms. For this reason payments to domestic firms "retained outside" would not be very significant in the import categories of the balance of payments. This means that practically all of the purchases from abroad in 1939 were paid for by an outflow of money from the region. This is in contrast to the situation on the export side of the balance of payments. When the Mountain West imports it must send out the money to pay the firms from which it buys, for these firms are located outside the region. On the other hand, when the Mountain West exports it may not receive payment for its exports since the exports are owned by absentee firms outside the region. For example, a payment to the Anaconda Company for copper shipped from Butte, may go, not to Butte, but into the New York offices of Anaconda.

In view of the underdevelopment of manufacturing in the Mountain West in 1939 relative to the production of raw materials, it is probable that the bulk of the net imports of commodities into the region is composed of manufactured goods. These imports include thousands of items originating in all parts of the United States and in many foreign countries. Only two relatively simple, but important, items are reported here, merely as illustrations of the general situation. 
The automobile industry is scarcely represented by manufacturing plants in the Mountain States. After making allowance for demand satisfied from domestic production, it is estimated that over $\$ 52$ million left the region in 1939 to pay for passenger cars imported. Similarly, domestic production of farm machinery was insignificant in 1939. The estimate of net imports in the year of farm implements and machinery, including trucks and tractors, is \$30 million.

Purely by coincidence, the estimated value of farm implements and machinery imported in 1939 just equaled the regional export of wool. Thus, in a sense, one can say that our wool exports were used to buy the machinery which the agriculturists of the region acquired in that year.

The Mountain West is a large importer of services from other parts of the country. "Foreign" companies provide the region with transportation and communication facilities. These companies also invest in maintenance and additions to equipment in the region so that the net export of funds probably is not large. Insurance is an important service purchased almost entirely outside the region. Five life insurance companies are listed in the 1940 Moody's as being domiciled in the Rocky Mountain Region in 1939. In spite of the fact that these companies sell insurance in other states as well as regionally, their total sales were only a fraction of all life insurance sales made in the Mountain States in 1939. It is estimated that, in net, roughly $\$ 6$ million was exported for life insurance purposes in that year. This figure makes allowance for death claims, matured endowments, surrender payments, and dividends paid to policyholders in the region. No computation was made of the dividends paid to resident owners of stock companies selling life insurance. This item is representative of those service industries which are on a net import basis.

The purchase of insurance of all kinds outside the region 
represents an important net drain of funds from the Mountain West. Very little of these funds have been reinvested in the region by the companies which control them. This situation tends to create a shortage of investment funds in the region and, consequently, to retard the industrial development of the Mountain West. ${ }^{4}$

\section{Financial Transactions: Role of the Federal Government}

The typical balance of payments for a nation almost always records important financial transactions. It would be very unusual for exports of goods and services to balance exactly against imports so that, normally, a country will be borrowing or lending on capital account through the activities of its nationals in the financial and investment markets of the world. This borrowing may be short-term or long-term; and, in addition, speculative purchases or sales of securities and foreign exchange will create net balances of funds.

Somewhat the same sort of activity takes place in interregional economic affairs, and numerous references to these transactions have been made in the preceding paragraphs. Westerners may buy securities on the New York Stock Exchange, and the General Electric Company may set up a new branch warehouse in Denver, or the F. W. Woolworth Company open a new retail outlet. Here, again, the transactions are too numerous and too intricate to trace successfully.

There is, however, one important element in interregional transactions which can be estimated with some degree of certainty. This is the role of the Federal Government in the economic life of the region. In 1939, taxes amounting to nearly $\$ 68$ million were collected in the Mountain West by

${ }^{4}$ In 1949 the Prudential Insurance Company established a Western Home Office at Los Angeles and announced a policy of expanding its investments in the Western states. 
the Federal Government. During the same period, the Federal Government paid out in the Rocky Mountain States some $\$ 343$ million. This payment includes an estimated $\$ 86$ million in wages and salaries and \$257 million in direct payments to states under co-operative arrangements, plus grants to and expenditures within the states providing direct relief, work relief, and other such aid. This means that there was a net import of federal funds to the extent of $\$ 275$ million. In other words, the Mountain West had $\$ 275$ million available for the purchase of goods and services outside the region. This sum exceeded the value of minerals exported in the same year. It may be compared, also, with the estimated export of $\$ 72$ million of livestock, $\$ 27$ million of wheat, and \$3o million of wool. Clearly the transactions of the Federal Government form a very significant item in the balance of payments of the Mountain West.

It should be noted that these estimates of government transactions are imperfect when used for balance of payments purposes. The tax figures do not include all payments made to the Federal Government by Rocky Mountain citizens. Prices paid to federal enterprises, such as National Park admission fees, are not included. On the other hand, the federal payment figure does not include all government expenditures. The \$343 million excludes purchases of materials and supplies in the region. To the extent that the government purchased commodities in the region and used them outside, there would be some duplication with the export figures already calculated without regard to the nature of the buyer of exports. The only meaningful figure would be federal purchases in the region for use therein, and this is difficult to separate from figures of total expenditures. In one important case, expenditures for construction by the Bureau of Reclamation, the Federal Government spent 21 to 24 million dollars in the Mountain West in 1939. Since 1945 Bureau ex- 

penditures in the region have been much larger than before the war.

Whatever the shortcomings of the estimates presented, they point unmistakably to the conclusion that payments by the Federal Government to the Mountain West greatly exceed payments of the region to Washington. Moreover, the excess is far out of line with what could be expected from deficit financing alone. In this year, total federal expenditures exceeded total federal receipts by 68 per cent. On this basis, an expenditure of around $\$ 114$ million (rather than $\$ 343$ million) would have been in keeping with the national average.

\section{Striking a Balance in Inter-Regional Trade}

It is now time to summarize - to attempt to find the pattern indicated by the straws we have cast into the wind. Three major points emerge.

(1) The export of minerals probably is the most important item in total exports of the Mountain West, and in this sector there is a possibility that a significantly large part of the proceeds from such exports are "retained outside" the economy.

(2) Agricultural exports probably are matched by a return flow of funds equal in value to the exports.

(3) The Federal Government is responsible for a very large import of funds into the region.

From these observations we are led to the tentative conclusion that federal payments make it possible for the inhabitants of the Mountain West to purchase goods abroad in larger volume than otherwise would be possible. Consequently, the import of goods and services exceeds exports of goods and services from the region. 
A balance of payments must balance in the accounting sense, we are told. If a nation buys more than it sells, it must borrow to cover the difference, or draw on the proceeds of its foreign investments. A regional balance of payments must also balance; and, in the case of the Mountain West, it would appear that the balancing item is Federal Government expenditures in the region. By analogy, the Mountain West is in the position of a "new country" being developed by "foreign" investment. The loans, however, are not a charge on the people of the region, but on the people of the United States as a whole.

If this is the case, the average American might be excused for asking, "Is it worth it?"-as indeed, sometimes he has. However, the very asking of such a question implies that in some sense the questioner regards the Mountain West as a "foreign country" so remote from New York and New England that private investors do not wish to risk their funds so far from home, and so remote from Washington as to raise little concern there for the welfare of so backward a region.

Fortunately, little of this is true. The United States is a single, integrated economy of which the Mountain West is an integral part. Congress long ago established the principle that federal subventions to the states should be made on the basis of need and with little or no regard to the amount of federal revenue derived from a particular state or region.

The wisdom of this policy is evident. It has helped to prevent the creation of extremely serious divergences in per capita income among the regions of the country and permitted the various regions to share more equitably in the national income. In providing for highways and social security on a national basis, the congress has minimized regional differences and increased the homogeneity and unity of the entire nation. Without such a policy the West and the South might have remained far more backward and undeveloped 
167 A "Balance of Payments" for the Mountain West than they are today; and the United States might have repeated the pattern of economic diversity which still characterizes Western Europe and impedes its current efforts to achieve unification.

A further justification for allowing federal expenditure to exceed federal revenues in the Mountain West-or in any other region-is found when the expenditures are of types which not only increase income in the short-run, but also increase the productivity and economic efficiency of the region, thus raising both the regional and national output. The type of expenditure most directly calculated to do this is investment in new capital goods for purposes of developing and conserving resources. Consequently, a good case can be made for a policy of maintaining and expanding federal investment in such Western enterprises as reclamation, hydroelectric power, development of forests, and range conservation. Such expenditures are clearly in the national interest. They will yield direct money profits on the national investment, as well as indirect social benefits of inestimable value. 


\section{Chapter 13. Institutional Barriers to Regional Development}

For nearly three-quarters of a century the Mountain West has been the last frontier region of the United States. In the early part of this period-the 7o's and 80's-it was a true frontier in the strict sense-virgin territory, invaded and utilized for the first time by cattleman, miner, and pioneer settler. Later its status became that of a colonial frontier. During the 9o's its primary resources came under the control of absentee, Eastern owners; and for a while the Mountain West served mainly as a convenient source of supply of valuable minerals and the beef and wheat of an extensive agriculture.

Today, neither of these attributes of the frontier has disappeared in the Mountain West, but they are no longer the dominant characteristics of the region. The primary thesis of this book is that the Mountain West is about to become a frontier in a new sense-a frontier in which untapped resources are to be utilized by means of integrated programs of multiple-purpose resource development and conservation. The westward movement continues to be a force in American life and its influence is likely to be enhanced in the future by government policy favoring large public investment in the 168 
development of the water, forest, and mineral resources of the West. Also, there are important economic and strategic forces at work in the United States which tend to promote the regional decentralization of industry, south and west from the Atlantic-Great Lakes industrial heartland. The course of future events is not certain, however. Standing against the drift toward the West are barriers which help to check or abort Western development and to protect the established dominance of the East. Over the decades certain patterns of behavior and attitudes of mind have developed in our society which now have outlived their usefulness. Yet by virtue of long life and familiarity they have achieved status in society and have been incorporated into our laws and ideology. Among these institutional barriers to Western development two stand out as major threats to Western expansion-the freight rate structure, and the basing-point system of pricing.

\section{Freight Rates Do Matter}

From the beginning the West has recognized the importance of rail transportation to its economy. The Granger Movement of the 7o's was directed against the discriminatory practices of the railroads, and it led to state and federal regulation, and to the establishment of the Interstate Commerce Commission in 1887. In recent years protests against rate policies have risen again in volume. In 1939 the ICC, moved by numerous complaints, undertook an investigation of the freight rate structure; and in May, 1945, it ordered a drastic revision of class rates and the creation of a uniform scale of intra-territorial and inter-territorial class rates. It further ordered that the practice of maintaining a separate classification of freight in each of the freight rate territories be abandoned and replaced by a uniform national system of classification of 
freight for rate-making purposes. This order was appealed by a group of Eastern states and railroads, but was upheld by the Supreme Court and became legally applicable in May, 1947.

The decision to enforce uniformity throughout the United States for class-rates and commodity classifications was a substantial victory for the West in its struggle for economic expansion; for the great weakness of the freight-rate system has been its diverse and illogical character. The freight-rate structure of the country has grown up by accretion over many decades. As the nation grew and the railroads were extended westward and southward, the country was divided into "territories" for rate-making purposes, each territory having its own rate structure for shipments within the territory, and each one having its own basis for calculating rates for goods shipped across its boundaries into other territories. All of these rates, moreover, were derived from the rates in "Official" or Eastern Territory, which lies east of the Mississippi and north of the Ohio.

In a like manner as new products were offered for shipment year after year, new rates were set up for them, and, inevitably, different definitions of a "product" evolved in the different territories, and different rates were charged for products which were in fact identical in character. Also there grew up a system of "Commodity" rates to take care of lowvalue bulky materials, and "Exception" rates to take care of almost everything else. The only discernible principle which held all of these rates together in a so-called system was the principle of charging what the traffic would bear.

For a number of reasons this hodge-podge "system" evolved in such a way as to favor the established "official" territory and discriminate against the other regions of the United States. The Board of Investigation and Research which studied railroad rates for Congress, reported in 1943 
that if the average of first-class rates for distances up to 1000 miles in Official Territory be taken as 100, the average of such rates in Southern Territory was 139; and in the four zones of Western Trunk-line Territory the average rates were 28 per cent, 46 per cent, 61 per cent and 84 per cent above average rates in Official Territory. ${ }^{1}$

The effects of such a rate structure on the West can be revealed best by specific examples. One such example is found in the experience in recent years of the meat packing establishments of the Western States (Idaho, Wyoming, Utah, Colorado and western Nebraska). Since 1940 three rate revision cases of major importance have been put before the Interstate Commerce Commission by Western meat packers and stockyard operators. The decisions in these cases have been a great material benefit to the stock growers and processors of the region.

The first attack on discriminatory rates involved several individual petitions submitted to the ICC in 1939, and decided as a unit in May 1940. In this instance Denver packers took the lead in arguing that rates on fresh meats to destinations east of Illinois and on the Atlantic seaboard (Official Freight-rate Territory) discriminated against the shipment of meat products from Denver in favor of the shipment of live animals from that point. They also contended that the rates discriminated against the shipment of fresh meat from Denver in favor of fresh meats shipped from interior Iowa packing plants.

Inevitably the evidence on these points is lengthy and detailed. It may be summarized by two comparisons: In Denver the protested rate on fresh meat was $\mathbf{1 5 9 . 6}$ per cent of the rate on live animals. At competitive points the differential between fresh meat and live animals varied from 132.1 per

1 United States House Document No. 145, Summary Report on Study of Interterritorial Freight Rates. 78th Congress, 1st Session (Washington, D. C., March 3o, 1943), p. 4 . 
cent to 142.4 per cent. ${ }^{2}$ Clearly, the Denver rate on meat was high in comparison with the typical difference between rates on meats and animals at other points. Also, it was shown that the carriers were able to earn 20.35 cents per car-mile on fresh meat shipped from Denver to New York City, whereas shipment from twelve Midwestern packing centers yielded an average return of 18.89 cents per car-mile to the railroads. ${ }^{3}$ On this evidence the ICC awarded the Western packers the requested lower rates on fresh meats.

A second complaint in $1945,{ }^{4}$ and a third in $1948,{ }^{5}$ were similar in nature. The more recent case was important for Denver because the existing rates made the slaughter of lambs in Denver expensive in relation to the shipment of live animals to eastern points. Denver usually ranks as the largest lamb market in the entire western area, where much of the national production of sheep and lambs is concentrated.

The major complaint in the 1945 case concerned rates on fresh meat and live animals from midwest and western points to the Pacific Coast states. In these states the growth of population and income had created a rapidly expanding market for meat and meat products. Before the war this market had been supplied chiefly by Coast-state packers who "imported" live animals from states east of the Sierras and west of the Mississippi. By 1945 packers in the cattle-producing areas were making a serious effort to secure a share of the West Coast market, and, consequently, petitioned for rate revision.

2 Interstate Commerce Commission: Decisions of the Interstate Commerce Commission of the United States (Washington, D. C., United States Government Printing Office, 1941), Vol. 238, Docket No. 4625, p. 611.

3 Ibid., p. 613 .

4 Interstate Commerce Commission: Decisions of the Interstate Commerce Commission of the United States (Washington, D. C., United States Government Printing Office, 1946), Vol. 263, Docket No. 28978, pp. 9-69.

${ }^{5}$ Interstate Commerce Commission: Report of the Commission. No. 295461. (Mimeographed). Decided April 3o, 1948. 
This case illustrates the complexity and expensiveness of rate revision through appeal to regulatory bodies. The ICC report lists the interested parties to the case in the following terms:

Summarizing, the complainants and supporting interveners are: (1) the railroad commissions of Iowa, Kansas, Nebraska, Minnesota, and South Dakota, appearing for and in behalf of livestock producers, farmers, and packing house interests in those States generally; (2) 18 so-called independent meat-packing and slaughtering concerns in the origin territory from Madison, Wis., and East St. Louis, Ill., on the east, to and including Denver on the west; (3) stockyard companies at Denver, Omaha, and Wichita; (4) associations of livestock producers and farm organizations in Kansas and Nebraska; and (5) organizations of independent retail grocers and meat dealers in southern California and Oregon. A witness representing a consumers league in Los Angeles also testified in support of the complaints. . . .

... Practically the entire meat-packing, slaughtering, livestock and allied interests in the Mountain-Pacific territory, including Arizona Corporation Commission, Public Utilities Commissioner of Oregon, Department of Public Service of Washington, Public Service Commissions of Wyoming, Utah, and Nevada, Public Utilities Commission of Idaho, Railroad Commission of California, Montana Board of Railroad Commissioners, Nebraska Livestock Auction Association, Wholesale Butchers' Association of the San Francisco Bay Area, 25 independent packers in Los Angeles, independent packers and livestock interests in the north Pacific coast area, and numerous independent packers, stockyard companies, feed dealers, chambers of commerce, and State, local, and national organizations of livestock producers, wool growers, feed dealers, and farmers in the destination States intervened in opposition to the complaints, and most of them submitted evidence. . . .6

6 Interstate Commerce Commission: Decisions of the Interstate Commerce Commission of the United States (Washington, D. C., United States Government Printing Office, 1946), Vol. 263, p. 11-12. 
The contention of Denver packers that rates on fresh meat from Denver to the Pacific Coast were too high was supported by the fact that carrier earnings per car-mile on meat from Denver to San Francisco were $25^{\circ}$ per cent of the earnings on the shipment of packing house products between points on the Pacific Coast. Also, from Denver to California the rates on packing house products were about double those on livestock. ${ }^{7}$ This case, like the other two, was decided in favor of the complainants.

Western stockgrowers and meat processors have been well pleased with the results of the rate revisions growing out of the three cases just outlined. In Denver, for example, the slaughter of cattle and calves has increased so rapidly that the increase cannot be explained solely in terms of the general rise in meat consumption and prices resulting from the war and post-war prosperity. As the following table shows, cattle slaughter in Denver has increased about 300 per cent over 1940, when the first rate reduction was won. Total cattle slaughter in the United States rose by about 59 per cent in the same period (Table 12). The relative increase in meatpacking in Denver is shown by the fact that Denver's share of total national slaughter of cattle has increased consistently from 1940 to 1948 (Table 13). In 1948 the Denver packing plants also slaughtered 848,000 lambs. This is more than twice the average slaughter in a number of years immediately preceding the 1948 rate revision.

The regional advantages of this increase in the indigenous processing of local raw materials have been substantial. It has meant more income and more employment within the region. From the regional point of view, this is a step in the direction of raising regional income closer to the national level. Second, the shift has resulted in a larger net return to stock growers, to the extent that they have been able to sell 
their animals in a nearby market, and avoid paying transportation costs to distant markets. This factor has been particularly important in the case of lamb slaughter. A third source of local benefit is seen in the significant expansion of slaughter facilities in the Denver area. Several small new independent packers have constructed plants in Denver since 1945. Perhaps the largest single new enterprise is the Landers Packing Company which in 1948 completed a new lambslaughtering plant with a weekly capacity of 16,000 animals.

The general advantages and disadvantages to the entire economy of this particular regional shift in economic activity are very difficult to assess. The losses experienced by rival centers, such as Omaha, or Los Angeles, probably had a mini-

TABLE 12: Index of Slaughter of Cattle and Calves Under Federal Inspection at Selected Stations, 1940-8.

$($ I $936-40$ average $=$ 100)

\begin{tabular}{|c|c|c|c|c|}
\hline & Denver & Omaha & Sioux City & United States \\
\hline I 940 & 87.7 & $99 \cdot 4$ & IOI. 4 & $97 \cdot 5$ \\
\hline I94I & I I 4.5 & I I 4.5 & I 24.6 & $\log \cdot 4$ \\
\hline $194^{2}$ & 167.5 & I 23.5 & 132.6 & 123.4 \\
\hline I943 & I $94 \cdot 3$ & 134.4 & I 5 I. 4 & I I 7.2 \\
\hline I 944 & $231 \cdot 4$ & I $44 \cdot 7$ & 146.1 & 139.5 \\
\hline 1945 & 210.9 & 150.2 & I 43.1 & I $45 \cdot 3$ \\
\hline I 946 & I 7 I.4 & 95.0 & 98.9 & I I 4.1 \\
\hline I 947 & $223 \cdot 5$ & I $55^{\circ} 0$ & I 53.9 & I 55.2 \\
\hline $\begin{array}{l}\text { I } 948 \\
\text { (est.) }\end{array}$ & $277 \cdot 3$ & I I 4.2 & I I $4 \cdot$ I & I 29.9 \\
\hline
\end{tabular}

$3^{6-40}$

Average

(thousands of head) I 26.6 748.4

362.0 $10,004.6$

Source: United States Department of Agriculture: Agricultural Statistics: 1947 (Washington, D. C., United States Government Printing Office, 1948), Table 424 . 
TABLE 13: Slaughter of Cattle and

Calves in Denver, Colorado, as a Percentage of Total United States

Slaughter 1940-8.

\begin{tabular}{rl}
\hline \hline 1940 & I.1 $4 \%$ \\
41 & 1.32 \\
42 & 1.72 \\
43 & 2.10 \\
44 & 2.10 \\
45 & 1.90 \\
46 & 1.90 \\
47 & 1.82 \\
48 & 2.20 \\
\hline
\end{tabular}

SOURCE: Ibid., Table 424 .

mum effect on packers there because the reductions occurred during a period of general expansion and increasing slaughter. Also it is quite possible that the losses were widely diffused and, consequently, unnoticed. The shift probably increased the over-all efficiency of the meat packing industry since it tended to reduce the volume and length of haul of live animal transportation and increase the more efficient transfer of meat or meat products. It is doubtful, however, if consumers were able to enjoy any appreciable benefits from this saving in view of the level of retail meat prices during the period. The meat cases did establish the existence of a specific rate discrimination against producers in a particular region. Also, they reveal the nature of the obstacles which stand in the way of a specific rate revision. In order to present a case, numerous interested persons must be brought together and persuaded to bring action, with all the expense and controversy which action involves. Once inertia has been overcome and action initiated, active opposition to the rate change will be encountered and must be combatted. Individual rate revision is not always as easy and automatic as the opponents of general revision claim. 
In the meat packing cases just cited the issue of interterritorial classification was not involved. An example of the common practice of classifying an identical commodity differently in different freight rate territories is supplied us by the testimony of an official of the Colorado Fuel and Iron Company in the hearings on the Class Rate case. The commodity in question was shell body forgings to be supplied to a plant in Omaha, Nebraska. At Pueblo, Colorado (Western Trunk Territory) this commodity was classified to carry a tariff of 45 per cent of the Class A rate; while in Pittsburgh, Pennsylvania (Official Territory) the same article at the same time was rated lower-40 per cent of first class. Under a uniform classification system the same commodity would be given the same rating, as a percentage of the class rate, at every point of origin located anywhere in the United States.

The discriminatory effect of this double classification of the identical commodity originating in different regions was further heightened by the additional difference of unlike rates per mile. Consequently, the Colorado Fuel and Iron Company, or its customer in Omaha, had to pay $\$ 1.05$ per hundred on shell body forgings for a haul of 601 miles from Pueblo, while a Pittsburgh shipper enjoyed a rate of 99 cents for a haul of 922 miles from Pittsburgh to Omaha! ${ }^{8}$

In discussing the implications of this discrimination, Frank L. Barton remarked that, "As the western United States becomes industrialized it will ship new commodities, and it is unfair for a western-located industry to have to wait until the problem arises, only to discover that variations in classification impose extra and unexpected handicaps." 9

The Interstate Commerce Commission and the Supreme

8 Frank L. Barton: "Economic Effects of Discriminatory Freight Rates,” Law and Contemporary Problems, 12:507-531, Summer, 1947, cited: Transcript of Record, States of New York, Delaware, et al., v. United States, et al., Supreme Court of the United States, October Term, 1946, Exhibit 92, 2503 .

\footnotetext{
9 Barton, loc. cit.
} 
Court have confirmed this point of view in even broader terms. In the Class Rate decision on May 12, 1947, the Court held that discrimination had been established by substantial evidence, and that this discrimination in the class-rate structure had handicapped the economic development of the South and West. The Court held, also, that discrimination against individual shippers was not the paramount issue, but prejudice to a region as a whole.$^{10}$ Consequently, the decision of the Court did not turn solely upon evidence of individual discrimination of the kind cited in the preceding examples of meat and steel, but upon more general economic analysis; and the decision to require uniform class rates and uniform classifications throughout the United States was directed toward securing for the South and West ample opportunity for economic expansion.

In the West the railroads have vigorously defended their rate practices in the courts and elsewhere. The argument of the various spokesmen for the railroads is to point to the recent expansion of industrial activity in the Mountain West as evidence that discrimination does not exist against the region. They assert that in hundreds of cases rate adjustments have been made voluntarily by the railroads in order to encourage Western industrial expansion and to build traffic on their lines. In defending this position some industrialists have gone so far as to argue that freight rates "do not matter" because the individual can secure a satisfactory rate for his product by negotiation with the railroad.

The protests of the railroads against revision of the rate structure seem to be motivated by the fear that disturbance of the existing rate structure will adversely affect their ability to earn satisfactory revenues. Consequently, the railroads have opposed over-all rate revision, preferring to deal with

${ }^{10}$ Brainerd Currie: "Foreword," Law and Contemporary Problems, 12:397-8, Summer, 1947 . 
individual shippers on the narrow issue of a specific rate for a certain commodity between a limited number of points of origin and destination. In support of their position it may be observed that there is evidence that specific rate revisions satisfactory to the shipper are being made constantly on a purely voluntary basis, without the necessity of appeal to the regulatory bodies.

But the issue hardly ends there. If a proposed rate revision is of major importance, opposition to the proposal is certain to arise. Then the proposal becomes a matter of controversy to be settled by the due procedures of the Interstate Commerce Commission or state regulatory bodies. In such cases rate revision is likely to require protracted and expensive negotiation; and only the well-established, larger shippers can afford to press for revision. Consequently, small producers are shut out, and embryonic producers die stillborn without ever getting a chance to compete with producers in other regions. Moreover, since specific revisions are based on the existing structure of rates, the rate system does tend to limit the degree and effectiveness of individual rate revisions. Thus, the rate structure itself may result in discrimination among regions, and revision of the structure may be required in order to permit a regional economy to develop its own industries and process its own raw materials. Freight rates do matter both specifically and in general; and the freight rate structure does influence the future of the West. Consequently the recent order to achieve uniformity and logical classification of rates is very significant. It should yield a major improvement over the ancient, crazy-quilt structure, whose primary virtue is that it has been endowed by its defenders with the veneration and sanctions of an inviolate political and social institution. 


\section{The Ideal Freight Rate Structure}

The full effect of the Class Rate decision cannot be seen for several years. It is no easy task for the railroads and other carriers to revise the thousands and thousands of rates and classifications which make up the freight rate system. In the meantime it is well to realize that while uniform rates will tend to remove present discrimination against the West they are not necessarily the best solution to the freight rate problem. The ideal freight rate structure would allow each region to develop according to its natural economic advantages. Because these economic advantages change in type and character over time in a dynamic society such as ours, it follows that the rate structure must be flexible and subject to change also. What the West objects to, once more, is the attempt of non-Westerners to institutionalize the existing structure and to maintain the status quo in the face of dynamic changes in economic fundamentals.

At the present time the Mountain West might well demand a preferential rate structure in order to offset the competitive advantages such as patents, trade-marks, and established outlets, which Eastern manufacturers enjoy. The West also should seek for a reversal of the present over-all bias in the rate structure which favors the movement of raw materials over the movement of semi-finished or finished goods. This is a necessary step toward Western processing, as the meat packing examples demonstrate. Finally, it should be realized that the ideal rate structure cannot be described without the determination of the optimum organization of industry and agriculture in the Mountain West. Evidence in this book has shown that the Mountain West at present is too dependent upon agriculture and underdeveloped in manufacturing. However, the proper balance between them is yet to be determined, and further research in the regional econ- 
omy is necessary. Such research would also attempt to discover the ideal position of the region in the national economy, from which some estimate of the volume and direction of inter-regional commodity and services movements might be derived. Then, and only then, will the nature of the ideal freight rate structure begin to emerge. Such a structure, when achieved, would facilitate the optimum development of the region to the direct benefit of the other regions of the national economy. The economic regions of the United States are co-operative as well as competitive, and policies which strengthen the parts may be expected to benefit the whole.

\section{Regional Impact of Basing-Point Pricing}

The Supreme Court decision outlawing freight-rate discrimination against the West and South was followed by a brief lull in public controversy over Western development; but in April 1948, another court decision gave rise to even more extensive and violent controversy. This new decision, rendered in United States $v$. the Cement Institute, et al., ${ }^{11}$ had the effect of outlawing the system of basing-point pricing, common in much of our heavy industry. The decision was immediately protested by a large segment of business enterprise, and an investigation of the probable effects of the decision was instigated by Senator Capehart ( $R$ ), of Indiana. ${ }^{12}$ In the Mountain West, protest against the decision was led by the cement manufacturers and sugar refiners who were supported by numerous chambers of commerce and civic groups.

The salient feature of basing-point pricing is the quota-

11 Federal Trade Commission v. Cement Institute, et al., 330 U. S., 67 SCt. 967, 91 LEd 1268, granting cert. ${ }_{157}$ F2d 533 .

12 After the election in November, 1948 , the chairmanship of the investigating committee passed to Senator Edwin C. Johnson (D), of Colorado. 
tion by different sellers of identical prices to buyers at different locations. Price identity is achieved by designating certain shipping points as "basing points" and setting the price at the place of delivery to include freight charges to that place from the nearest basing point. For example, Chicago was, until recently, the nearest basing point for the pricing of steel for the entire eight states of the Mountain West; while the dominant regional producer of steel was the Colorado Fuel and Iron Company at Pueblo. Yet the Western buyer who purchased steel from the C. F. \& I. was quoted a price at Pueblo which was the price of steel at Chicago plus freight from Chicago to point of delivery to the buyer. Thus, the price of steel to the Western purchaser included freight charges for a thousand miles of imaginary transportation. This situation usually results in price discrimination against the Western buyer, for the Western producer sells his product to the near-by, regional customer for a higher net return than he receives for sales to customers who are located farther away in the direction of the basing-point-customers in Iowa or Nebraska, for example.

The case of steel is one example of the serious price discrimination which has been practiced against the consumers of the Mountain West by numerous industries. Every purchaser of gasoline in the Mountain States pays "freight" on that gasoline from "Oklahoma Territory" even though the petroleum is pumped from the ground in the Mountain West and refined into gasoline in a refinery a short mile from the customer's filling station. ${ }^{13}$ In the same way every local consumer of the beet sugar grown and refined in Utah or Idaho pays phantom freight, as if the sugar had been shipped from San Francisco, the nearest seaport for competitive cane sugar

13 United States Temporary National Economic Committee: Investigation of Concentration of Economic Power, Hearings ... Part 5; Monopolistic Practices in Industries (Washington, D. C., United States Government Printing Office, 1939), pp. 1937-8. 
grown in the Hawaiian Islands or the Philippines! Consequently, the consumer enjoys no price advantage in the existence of a local industry. If he has to pay freight from Oklahoma on his gasoline he might as well buy it there in the first place.

Discrimination against consumers, or buyers, is recognized generally as the major evil of basing-point pricing. The Western consumer has found the system a particularly costly method of exploitation because in most cases the nearest basing-point has been hundreds of miles away-at Chicago or San Francisco or even farther. For this reason the amount of fictitious freight has been large in many cases. The reader no doubt will recall having seen in the advertisements of consumer goods in the national magazines an inconspicuous footnote: "prices slightly higher west of the Rockies."

There are, of course, two beneficiaries of regional price discrimination. The primary beneficiary of the high price paid by the Western consumer is the regional producer. It is true that the Eastern manufacturer benefits to the extent that the basing-point system makes it possible for him to sell in the West at the same price as the Western manufacturer; and this may be an important advantage. But the Western producer lives under the umbrella of the freight pick-up which the basing-point system gives him. He asks for and collects a freight charge which he pockets himself instead of paying it out to the carrier as an operating expense. It may not follow that he is able to earn excessive profits by virtue of the freight pick-up. Sometimes, to be sure, he receives monopoly profits; but his own operating costs, as a small-scale producer in a sparse market, may be high and he may need the phantom freight just to survive. Regionally his existence is of immediate benefit to the economy of the region. His payroll is regional; and in all probability he is processing local raw materials which otherwise would remain undeveloped. Never- 
theless, the regional consumer "pays the freight." In effect he is subsidizing a high-cost local industry, without his knowledge or consent.

Conceivably, the Western consumer might not object very strenuously to giving a subsidy to the regional producer if he could have some assurance that eventually the Western producer would become well enough established to be able to reduce his costs and his selling prices. Unfortunately, however, logic and experience indicate that there is little possibility that this will occur. Ordinarily, the very existence of the regional producer is dependent, to a considerable extent, on the decisions and policies of the larger producers outside the region. By virtue of basing-point pricing the Eastern producer is able to sell in the regional market at the same price as the regional producer. The essence of the basingpoint system is that the prices quoted are identical at each destination; so the large, distant producer knows that he will not be underbid by a competitive regional producer. The outside, distant producer benefits from this situation by gaining increased total sales; and the growth of the Western producer is limited by the willingness of the Eastern seller to tolerate the presence of the Westerner as a partial supplier of his own regional market. If the Western market expands, as it has in recent years, the Eastern supplier can increase his sales, but the Western producer is no more able than before to break through the restrictions of the basing-point system. His market is limited by the sales of the outside producer; and his motive to expand is weakened by the freight differential which he enjoys. Under these conditions the enlarged Western market is likely to be served by branch plants of the Eastern producer rather than by independent Western producers. Consequently, prices in the West remain high and the proceeds of Western sales flow east to swell the profits of the old, established, Eastern producer. 
Nor is this all. The retarding effects of the basing-point system on Western growth do not stop with the primary producer. They extend also to the auxiliary fabricating industries which might be expected to grow up around the regional basic industries under normal competitive conditions.

Two examples of actual situations should help to explain what happens. The regional beet sugar refining industry in the Mountain West enjoys a freight pick-up, as we have seen. It uses part of the proceeds so acquired to absorb freight on shipments of refined sugar to the East where beet sugar must be sold in competition with cane sugar from the refineries of the Atlantic seaboard. Such eastward freight absorption is possible under the basing-point system. However, if F.O.B. pricing prevailed then the Western beet sugar refinery could sell sugar in the East only by lowering the price of sugar at the factory by enough to offset the freight charges to the Eastern inarket.

A lower price at the Western refinery would mean cheaper sugar for the Western buyer, located close to the refinery, and the possible results of a reduced price for sugar in the West are most significant. If local buyers of sugar paid less for sugar consumed next door to the refineries in the Mountain West they might find it possible to buy more of the output locally. For example, a cheaper price for sugar in the West might very well result in the expansion of the processing of fruits and berries in the region, and in the manufacture of candy and confectionary for the regional market. The per capita consumption of candy in the Mountain West is very high-at least 25 per cent above the national average. Yet 80 per cent of the candy consumed in the eight states is shipped in from outside the region-something like $80-85$ million pounds per year. ${ }^{14}$ Because of this large local market rela-

14 "Confectionary Industry in the Rocky Mountain States," Better Business, Vol. 20, No. 2, June 1, 1947 (Boulder, Colo., Bureau of Business Research, University of Colorado, 1947). 
tively minor adjustments of production costs might be expected to give rise to a very rapid expansion in the output of a regional candy manufacturing industry. One way to achieve a significant cost adjustment would be through the lowering of the local delivered price on sugar.

A second example of the way in which the basing-point system discourages the establishment of regional fabricators was revealed to the Capehart Committee by Miss Ann Olson, Secretary-Treasurer of the Wire Specialties and Manufacturing Corporation of Denver, Colorado. Miss Olson testified that:

"It is almost impossible for a manufacturer in our regionoperating under this "ghost" freight handicap-to compete for his own market, much less compete in the territory half way to Chicago. It is utterly impossible for a manufacturer in our region to compete with a Chicago manufacturer and sell in Chicago; while a Chicago manufacturer can compete very nicely in Denver, due again, and only, to the basingpoint system with "ghost" freight." 15

In order to support her contention Miss Olson offered evidence comparing the costs of two manufacturers of wire specialties-one in Denver and one in Chicago. Three items were taken into account: (1) the cost of the raw material (steel wire), (2) freight on the raw material, and (3) freight on the finished product (coat hangers) from manufacturer to customer. Since the basing-point system prevails, it will be recognized that the cost of the steel is the same to both manufacturers-i.e. the Chicago price. However, the Chicago manufacturer paid no freight on the raw material, while the Denver manufacturer paid freight from Chicago, 1000 miles

15 United States Senate Committee on Interstate and Foreign Commerce: Study of Pricing Methods. Hearings before a Subcommittee of the Committee on Interstate and Foreign Commerce. 8o Congress, 2nd Session (Washington, D. C., United States Government Printing Office, 1948), p. 786. 
away, although the steel was supplied by the Colorado Fuel and Iron Company, 118 miles from Denver.

The problem of the Denver manufacturer is to deliver coat hangers to a customer in, say, Wichita, at the same price as the Chicago manufacturer. Miss Olson showed that this is very difficult, since the cost of the three items-raw materials plus transportation-to Wichita for the Chicago manufacturer was $\$ 4.75$ per hundred pounds; while for the Denver manufacturer the cost was $\$ 5.68$. Even in Salt Lake City, $57^{\circ}$ miles from Denver and 1,514 miles from Chicago, the Chicago manufacturer's cost was $\$ 5.52$ and the Denver producer's cost was $\$ 5.82$ per hundred pounds.

The significance of this example is easy to see. The Denver fabricator operates under a definite basing-point handicap. He can produce and sell only if his processing costs (wages, etc.), are low enough, and his profits on local sales high enough to permit him to absorb the freight when selling in competition with the Chicago manufacturer.

Some intrepid enterprisers will try, and they may succeed within limits. But most fabricators will gravitate to the basing-point, supplying the regional market from a distant center. The double locational pull of a regional market and a regional supply of raw materials will be overpowered by the locational attraction of the basing-point.

The basing-point system now stands revealed as a threefold enemy of regional development. It permits discrimination against regional consumers and forces them to pay higher prices for consumer goods. It retards the development of regional industries founded on the utilization of the primary resources of the region, and it discourages the growth of secondary industries, engaged in the fabrication of basic materials such as steel and sugar.

Most competent authorities recognize these three detri- 
mental effects on regional development. They have been pointed out by Hoover, ${ }^{16}$ and Machlup, ${ }^{17}$ and by Professor Frank A. Fetter, the foremost expert on the intricacies of basing-point pricing. In 1939, during the TNEC investigations of economic concentration, Professor Fetter said:

My judgment is that it (abandonment of the basingpoint system) would tend very largely toward decentralization of physical plants in industry, and would tend to decentralize the control of industry to a considerable extent, and to make industries serve their own communities to a greater extent, and make collusive prices more difficult if not impossible. ${ }^{18}$

Professor Fetter's judgment was reaffirmed by the $\mathrm{Su}$ preme Court in its decision of April 1, 1948, and so far no substantial evidence has been brought forward by the Capehart Committee or by any other agency, which seriously challenges its validity. The perpetuation of the basing-point system by legislation setting aside the decision of the Court would be most unfortunate, for it would prolong the life of an outmoded institutional barrier to the optimum development of the Mountain West.

The people of the Mountain West do not resent the fact that the East was able to achieve industrial pre-eminence by virtue of prior establishment in time. They do not even wish to challenge that pre-eminence. They do resent the fact that, as their turn for development comes, certain forces and interests to the East are busily attempting to perpetuate such artificial barriers to Western expansion as the freight-rate structure and the basing-point system of pricing. Moreover, the failure of the West to achieve its growth through the

${ }^{16}$ Edgar M. Hoover: The Location of Economic Activity (New York, McGraw-Hill Book Company, Inc., 1948), p. 310.

${ }^{17}$ Fritz Machlup: The Basing-Point System (Philadelphia, The Blakiston Company, 1949), p. 275.

${ }^{18}$ United States Temporary National Economic Committee, op. cit., p. 1937 . 

normal avenues of economic competition inevitably forces the region to adopt political weapons in the attempt to gain its ends. The use of political instruments for competition in the economic sphere may be inevitable, but it is most unfortunate that this use should lead to sectional conflicts among the forty-eight states.

A major purpose of the economic and social analysis of regions is to discover a basis for regional integration and cooperation in order to avoid the consequences of sectionalism in American life. In addition to an examination of the economic characteristics of regions such study requires an examination of the political aspects of regional relationships. This is the subject of Part V which follows. 
Part Five

POLITICS

AND

ECONOMICS 


\section{Chapter 14. Silver, Sheep}

No study of a regional economy would be complete without an examination of the regional significance of those political forces which are so closely allied with economic interests in the American commonwealth. The special-interest blocs, through which these forces operate, are of particular importance in the Mountain West because of the high degree of economic specialization which the location of resources has created in the region. Of course, the basis of organization of the special-interest group is functional; and, consequently, a bloc cuts across the geographic lines of organization of the federal government. Yet certain blocs are also sectional in character. Silver, sheep and cattle, and beet sugar are primarily Western commodities, and the center of strength of these particular commodity blocs is found in the West. These are Western blocs which operate on the national scene, and these chapters are concerned primarily with the effects of the activities of such blocs on the economic life of the region and nation. ${ }^{1}$

1 The special-interest bloc usually is active on state and local levels also. The copper group and the public utilities group, among others, have been very active in the West, but to study all of the activities of these and 


\section{Silver}

Of all the blocs in Washington none has had a more interesting or more successful career than the Silver Bloc. This lobby is made up of a mere handful of silver producers, most of whom represent large corporations which produce silver as a by-product of other non-ferrous mining activities.

The history of the Silver Bloc goes back to the days of intense mining activity in the West nearly a century ago. The modern period in its history began in 1933 when the Silver Bloc was quick to capitalize on the New Deal's penchant for experiment, and found it easy to sell the idea that a silver purchase program would aid recovery. Accordingly, by Executive Decree and by law, arrangements were made to purchase silver at rates well above its commodity price. These culminated in the Silver Purchase Act of 1934 which directed the Secretary of the Treasury to purchase silver in unlimited amounts "so long as the proportion of silver in the stocks of gold and silver in the United States is less than one-fourth of the monetary value of such stocks."

There followed a period of immense silver purchases, at ever-increasing prices, so that by 1949 the Silver Bloc had cost the American taxpayer nearly one billion, five hundred million dollars. Moreover, the greatest part of this money went to foreign sellers. From 1934 to 1946 , slightly more than one billion dollars of foreign silver was purchased, as contrasted with about 400 millions of domestically mined silver. Even so, the foreign silver was, comparatively speaking, a bargain. For it the Treasury paid on the average $5^{\mathbf{1}} \boldsymbol{\phi}$ per ounce, while paying anywhere from 64.4 cents to 90.5 cents per ounce for domestic silver.

other blocs would require a volume in itself. A good account of an important part of this picture is to be found in Joseph $\mathrm{K}$. Howard: Montana High, Wide, and Handsome (New Haven, Conn., Yale University Press, 1943). 
The whole episode was a colossal blunder. It is extremely unlikely that the policy aided recovery with any effectiveness. Nor was the Treasury able to approximate the 25 per cent reserve requirement, even though it did have to spend millions of dollars to construct vaults at West Point to store the thousands of tons of silver it actually acquired. The only ones who have benefited are the domestic silver producers who received a high price for their metal. All this, then, was done for a few hundred silver producers, for most of whom silver is a by-product of other metals, and whose total employment is an insignificant fraction of the labor force.

"How do they get away with it?" one may well ask. The answer is that the power of the Silver Bloc lies in a unique combination of selfishness, sentimentality, and monetary mysticism.

The Silver Bloc, like all blocs, is selfish. The degree of its selfishness has been indicated most painfully in recent years by the episode of the war use of silver as a metal. Silver has a number of important industrial uses. It is a very good substitute for copper or nickel in many cases, and when these metals became in seriously short supply, engineers and technicians immediately thought longingly of the Treasury's vast hoards of the white metal. Early in 1942 the Treasury arranged for the loan of its "free" silver to industrial users for nonconsumptive purposes. Industry was able to make use of a billion and a quarter ounces of metal in nonconsumptive ways - mostly as busbars in electrical installations. The Manhattan Project alone took 400 million ounces for use in the atom bomb plants. However, the release of silver for consumptive purposes was another matter. Enabling legislation by Congress was required, and here the Silver Bloc had to be consulted. They held out for the best conditions possible in terms of price and future policy concessions, with the re- 
sult that legislation was delayed from May 1942, until July 1943-fourteen months during which the metals shortage was critical and we were arming for the eventual invasion.

The selfishness of the Silver Bloc is further underlined by its willingness to use the cruder instruments of political power. Frequently the bloc holds back its silver bills until the last moment before recess or adjournment, then rushes them through in the confusion of last-minute attempts to clear the legislative calendar. It is adept at log-rolling and in trading of strategic senate votes to the larger blocs when the latter find themselves in need. Its deals with the farm bloc, in particular, are numerous and intricate.

The silverites are particularly effective in the use of the filibuster. In 1893 when the silver question was a burning issue, Republican Senator Henry W. Teller of Colorado filibustered for six long weeks in behalf of the free coinage of silver. In 1947 Democratic Senator Pat McCarran of Nevada, recently characterized by John Gunther as one of the 64 men who rule America, proudly reported to the Annual Convention of the Colorado Mining Association that he and his silver brethren had raised the Treasury buying price for silver from 71.11 cents per ounce to 90.5 cents by "successfully conducting the most arduous filibuster in history." 2 And with a modest inclination of his senatorial, silvered locks he seemed clearly to imply that, "although the going was tough, and maybe not the best of legislative practice, nevertheless, boys, we did it all for you."

Of course, the economic interests of at least ninety per cent of McCarran's listeners actually are contrary to the interests of the silver producers. Nevertheless, swayed by sentimentality, they gave the good senator a rousing ovation. For the truth is that the Silver Bloc owes a good deal of its in-

2 Hon. Pat McCarran in an address given before the $5^{\text {oth }}$ Annual Mining Meeting of the Colorado Mining Association and Associated Western Groups, Denver, Colo., February 7, 1947. 
fluence to its ability to appeal to the sentimentality of its supporters. Every good special-interest advocate knows that in order to be successful he must associate his personal ends with the general ends of the society. The Silver Bloc understands this very well; and, lacking a basis for an appeal to reason, they appeal to the emotions of the voter and the legislator.

The appeal is addressed, cleverly enough, to the average citizen's nostalgia for a romanticized past. In the 1890 's silver was romantic. About it hung the aura of that most rugged of individualists, the prospector, who risked his life and all he possessed to conquer the mountain fastness and emerge triumphant with a fortune. About it, too, there still clings all of the traditions of an agrarian, debtor West which struggles for cheap money and free silver in order to break the control of the Eastern creditors who fettered its development. This aspect of the silver issue has its own heroes, personified most effectively in the vivid character of William Jennings Bryan. The Great Commoner fought for silver. He did so as a part of his life-long fight for liberalism and reform. Thus silver, by association, also stands for social progress and for the rights of the common man.

Viewed in this way silver is progressive and democratic. How unfortunate that the reality of the present is so unlike the dreams of yesterday. Today, silver is the unromantic byproduct of the technological processing of copper and zinc ores. It is corporate, tightly controlled, and ultrareactionary.

Any bloc which can gild over its essential selfishness with a coating of sentiment is in a fortunate position. It is thrice blessed if it can add a generous portion of confusion to the issue. This the Silver Bloc does very well by taking advantage of the muddle and mysticism which surrounds the subject of money in the minds of many honest citizens and conscientious legislators. Somehow the silverites usually man- 
age to convey the impression that to "do something for silver" will, at the same time, add strength, security, and stability to our monetary system, and simultaneously insure prosperity and progress for all.

Nothing could be more hollow than these pretentions. The simple fact is that, except for dimes, quarters and half dollars, silver has absolutely no place in the modern monetary system of the United States. For centuries silver was the major metal in the monetary systems of the world, but the large gold discoveries in the middle of the nineteenth century increased the supply of gold and destroyed the historic ratio of 16 to 1 . Thus, after 1870 the bimetallists were fighting a losing battle, and by 1900 gold had become the basic monetary metal. Silver had lost its place as a useful part of the money reserve.

Although the silver battle was fought on the bimetallic issue in 1880 and 1890 , the real issue was not the technical question of an adequate specie reserve. It was the social and economic issue of the interests of debtor vs. creditor, and the industrial East vs. the agricultural West. Bryan, of course, was right in 1896 . At that time the free coinage of silver would have made for cheap money and would have tended to counteract the contemporary deflation which had so seriously affected the debtor class. Today, however, to depend upon silver to regulate the monetary supply or to aid the debtor West is about as sensible as to depend on a Colt .44 to protect us against jet-propelled bombers. Our modern banking system with its ability to create Federal Reserve notes and bank deposits on a fractional gold reserve basis has given us an extremely flexible money supply which fluctuates readily in response to changes in the volume of trade. We no longer need silver for the strictly monetary purpose of providing a specie reserve. Nor do we need it for purposes of economic control. If the West needs more money today it 
can appeal to the regional Federal Reserve Bank, to the R.F.C., or to any one of a dozen other federal credit agencies. Silver isn't even wanted for the simple task of paying the grocer and the druggist. Only a few sentimental Westerners carry silver dollars, and millions of Americans have never even seen one. (Ever try to give a New York taxi driver a silver dollar?) Consequently, billions of ounces of the white metal lie buried deep in expensive vaults, while paper substitutes called "Silver Certificates" circulate in its stead.

There is further proof of the irrationality of the role of silver in our monetary system. Recently the American Economic Association submitted a questionaire on monetary policy to those of its members who are recognized experts in the field of Money and Banking. Concerning silver, the economists were asked, "Do you think that the silver subsidies of 1933 and subsequent years were good (basically sound) economic ideas when adopted or were bad when adopted?"

The answers were: Good 1

Bad 53

They were then asked, "Do you think that silver subsidies should be continued?"

The answers were:

$\begin{array}{lr}\text { Yes } & \text { o } \\ \text { No } & 48\end{array}$

Such unanimity is indeed impressive in a field where controversy is commonplace and disagreement frequent.

Thus, on the evidence, we may conclude that in the United States silver is no longer needed as money, and its existence as money is actually an embarrassment. This is the sad truth which the silver advocates cannot understand. Or understanding, they attempt to confuse and mislead others less literate in economics than themselves.

The tactics and accomplishments of the Silver Bloc have been analyzed at some length because they typify the kind of economic thinking and political morality which lies behind 
much of the activity of the special-interest groups. There is more to the story, however. The Silver Bloc and its allies have much to do with the shaping of legislation dealing with the conservation and development of our mineral resources. Unfortunately we do not have such a program, although the need for it is great. The chief reason for the lack of a minerals program is that the Silver Bloc turns every attempt to create a broad minerals policy into a pork-barrel operation set up for the special benefit of the minerals lobby.

Congress passed a minerals subsidy bill in the 1947 session; but President Truman vetoed it, giving as his reason the opinion that the bill was not a genuine conservation measure but merely an attempt to perpetuate a wartime subsidy for the benefit of a small group of producers. ${ }^{3}$ The silver-minerals group tried again in 1948, but this time the bill failed of enactment, having been opposed in its early versions by the Bureau of Mines and the Secretary of the Interior. ${ }^{4}$

The obstructionism of the Silver Bloc is a serious affront to the national interest. For, as every expert knows, we need an adequate minerals conservation program, and we need it now. With the growth of our population and the expansion of our capital equipment, we have gobbled up minerals at a faster and faster pace. World War II brought about a further substantial increase in the rate of depletion of our reserves and at the same time virtually stopped exploration. Thus we must consider seriously the adequacy of mineral supplies -both for peaceful growth and for national defense. The plain fact is that we cannot go on using minerals as we do today without discovering new deposits of minerals or developing new techniques for utilizing low-grade ores. This

s "Memorandum of Disapproval," Congressional Record, 8o Congress, 1 Session, Appendix (Washington, D. C., United States Government Printing Office, 1947), pp. A4452-A 4453 .

${ }^{4}$ Congressional Record, 80 Congress, 2 Session (Washington, D. C., United States Government Printing Office, 1948), pp. $66_{39}-66_{4}$ o, $8935^{-893^{8}}$, 9404-9412. Similar bills were pending in the 81th Congress in 1949 . 
will require, in the one direction, geological surveys and mapping and geophysical exploration for new deposits. On the other hand, it will require much scientific research in methods of extraction and processing of low-grade ore and search for new physical and economic uses for the new inferior grades. Legislation directed to these broad national goals appears remote as long as the Silver Bloc persists in tying every proposed bill to the time-honored purposes of the pork-barrel.

\section{Sheep}

Historically, minerals were the foundation of the economy of the Mountain West and the primary source of the region's wealth. Today agriculture is the principal source of income, and it should be of interest to all of us that two of the region's major agricultural products are supported by special subsidies from the Federal Government. The protection and perpetuation of these subsidies is the basis for the activities of the pressure-groups which support wool and sugar in Washington.

About one-third of the sheep in the United States are grown in the range country of the Mountain West. But although mutton and leg of lamb are pleasing to the taste of many, the sheep-grower's primary interest is in the fleece rather than the flesh of the animal.

Domestic wool has enjoyed tariff protection in this country since 1816 , except for two brief interludes. Since 1943 a wool price support program has been in effect. Originally enacted as a war measure, the program has been continued on a year-to-year basis since the end of the war. Under this program the Commodity Credit Corporation is authorized to purchase domestic wool at prices which will insure the 
grower a fair return and to sell the wool to the textile trade in competition with foreign wool. In order to do this the CCG must take a loss of 8 to 16 cents on every pound of domestic wool sold for use by American consumers. Losses by the Commodity Credit Corporation on wool sales in 1946 amounted to approximately 14 million dollars. ${ }^{5}$

More important, perhaps, is the fact that the wool group, working with allies from the larger Farm Bloc, has not hesitated to jeopardize the whole program of international economic relations which the United States has worked out in an attempt to stabilize and build up world trade during the post-war reconstruction.

Most of us will remember the consternation which was created here and abroad when the House of Representatives adopted a bill on May 23, 1947, providing for a fee of $5^{0}$ per cent of the value of imported wool or woollens to be levied on such imports in addition to the already high tariff on wool. At that moment the Geneva International Conference on Trade and Employment was in session. Called on the initiative of the United States, the Conference was debating ways and means of increasing world trade.

The news from Washington of the House action and the subsequent concurrence of the Senate brought the Conference to a standstill. The Under-Secretary of State for Economic Affairs, Mr. Will Clayton, rushed home from Geneva to protest. Secretary of State Marshall protested also, and he was joined in protest by former Secretaries Cordell Hull and Henry L. Stimson. Mr. Stimson said in part:

"It is my considered opinion that to enact the House measure at any time would be most unwise. It would amount to a repudiation of the whole structure of American eco-

${ }^{5}$ United States Department of Agriculture: Report of the Secretary of Agriculture: 1946 (Washington, D. C., United States Government Printing Office, 1946), p. 72. 
nomic policy developed in the Congress and the State Department during the fifteen years since Cordell Hull began his work for trade agreements. And such repudiation now, when American leadership has been so largely responsible for the Conference on World Trade at present proceeding in Geneva, could not fail to have serious and immediate international effects, both economic and political. To other nations now watching for proof of American sincerity and unity it would be a shocking indication that the policy of the United States can at any time be shackled by the sort of economic shortsightedness for which all the world has paid so dearly in recent years." 6

The bill was vetoed by President Truman, but the passage of such a measure by both Houses of Congress undoubtedly had an adverse effect on American foreign relations.

The wool-growing industry offers a striking example of an industry whose long dependence on tariff protection has so weakened its vitality that it is unable to compete in the economic sphere. Consequently, it turns more and more to the arena of self-centered, pressure politics to secure its survival. Wool fiber is very desirable for many purposes, but the competition of synthetic fibers is steadily increasing. Certainly both viscose and acetate rayon fibers are available at much lower prices -25 to 40 cents per pound as compared with more than one dollar per pound for wool fiber.

Moreover, the American wool industry is inefficient. Very little is being done to meet the competition of the synthetics. In addition, the textile industry long has preferred foreign wools to domestic because of the more careful handling and superior preparation for market of the foreign wools. Yet the American wool grower has preferred to lobby for more protection rather than to improve his own product or produce it more efficiently. In the meantime the domestic 6 "Position on House Version
Bulletin, 16:1229-1230, June 22, 1947. 
clip is becoming smaller year by year and the number of sheep on farms is steadily diminishing.

Only recently has there been evidence of some attempts at the improvement of the wool industry by its own members. In April, 1948, the first American experiment in sorting wool at the shearing pens was undertaken at Rawlins, Wyoming. It was sponsored by Wyoming wool growers and the Department of Wool Technology of the University of Wyoming. Sorting at the pens has been the standard procedure in Australia for many years. In this country sorting has been done, expensively, at Eastern manufactories. The wool states are also engaged in the preliminary stages of an effort to establish a wool scouring industry in the West. The various state governments have been active in this attempt, on both a state and regional basis.

These are rational steps forward. If successful, they will improve the product and increase its competitive efficiency. Also such processing will augment the value-added-by-manufacture created in the region and thus help to improve the general productivity of the region. It is to be hoped that these first signs of a new attitude among wool-growers will lead to a far-reaching rationalization of the American wool industry.

\section{Sheep, Cattle, and Conservation}

In the early days of the West the sheepmen and cattlemen were bitter enemies, and disputes over the control of the open ranges often led to range "wars." Today a vociferous minority of the sheepmen have allied themselves with likeminded cattlemen in a concerted attack on the public lands and conservation policies of the national government. In- 
stead of fighting each other they have found it more advantageous to league together against the interests of the American people. In 1946 the presidents of the two powerful livestock trade groups, the National Woolgrowers Association and the National Livestock Association, met at Salt Lake City, Utah, and appointed a national working organization, the Joint Livestock Committee on Public Lands. In the following months various state organizations of sheep and cattle raisers created their own state-wide joint committees of cattlemen and sheepmen.

The purpose of this united effort is very clear. The ultimate goal of the livestock ranchers is to acquire ownership or control of the public range lands of the West, and even of large blocks of forest and park lands. The immediate goal is to oppose the efforts of the Forest Service to check the serious depletion of the range by restrictions on grazing. Both the long-run and short-run goals are highly inimical to the conservation of range resources and the protection of the forest watersheds upon which the economic life of the West directly depends.

The livestock growers of the West profess to be conservationists, and no doubt the great majority of them are. Their dominant leaders, however, are thoroughly saturated with the outlook and mentality of the special-interest group. Theirs is the short-run, egocentric, and selfish point of view. The control of the lobbying activities and policies of the industry rests in the hands of the leaders of the trade associations of the groups so that it is the minority which determines policy; whatever the real feelings of the majority. It is this small minority which has initiated the present drive against our public lands.

The basic economic origins of the present policy are not hard to find. Meat prices and profits were never higher, 
thanks to the wartime inflation and post-war boom. But high meat prices are not solely the result of impersonal economic forces. The high price of meat is a carefully tended flower in the lush economic garden of the post-war inflation. The American National Livestock Association and the American Meat Institute were instrumental in securing the destruction of price control and rationing. No pressure group in Washington was more active in this cause, not even the NAM.

High profits and prices obviously call for an increase in the number of meat animals. More animals require more feed; so it is not surprising that the livestock men are strongly tempted to overstock and overgraze the ranges in order to cash in on the immediate opportunity. Under such circumstances the public grazing and forest lands of the West are a natural source of additional forage. The temptation to overgraze public lands is all the more irresistible since the costs of range destruction are not borne by the rancher but by the public. The private operator usually thinks first of private lands. Consequently, the lobbyists have had no great difficulty in securing the acquiesence of the rank and file to their policy of attacking any restriction on grazing, even though the majority of Western sheep and cattle owners do not have access to the public range. ${ }^{7}$

The focal point of the strategy of the livestock group is the Congress. The livestock lobbies are adept at their trade and Western Representatives and Senators must always lend an ear to their importunities. Even the national figures such as Joseph C. O'Mahoney of Wyoming, are not immune. The strategy of the group is to weaken the Forest Service's regu-

${ }^{7}$ About 10-12 per cent of the cattle in the eleven Western States are grazed on public lands, and 25 per cent of the stock sheep. Public lands are the source of approximately 15 per cent of the forage required by the beef cattle and stock sheep of the area. United States Department of Agriculture, Forest Service, AIS, No. 8o, May 1949. 
lations of grazing by the enactment of legislation to restrict the functions of the Service, reduce its appropriations and limit the personnel. The tactics of the livestock men follow an easily discernible pattern. The first step is to make personal attacks on individuals from the local Forest Ranger to the Chief of the Service. The attack on the members of the Service is accompanied by an attack on the policies of the Service. Resolutions are adopted, alleging dictatorship by the Forest Service nearly every time a grazing permit is altered; and usually such charges are coupled with proposals for the sharing of control of the ranges by the permittees themselves. The stockmen further urge a moratorium on the reduction of grazing permits for a three to five year period, while at the same time charging that the Forest Service is lax in reseeding and improving the deteriorated range.

The task of harassing Forest Service officials at the local level is assigned to the various state and local associations. In Arizona stockmen in the vicinity of the Tonto National Forest have kept up a running fire against the rangers and supervisors of that forest, charging various individuals with incompetence and "lack of cooperation," and demanding their transfer or removal. The Poncha Springs Livestock and Range Improvement Association attacked their District Ranger in the San Isabel National Forest in a similar manner when he recommended a reduction in the number of livestock on the ranges of the forest. These are typical examples of a growing tendency to attack the integrity and competence of the local forest officials whenever a reduction in grazing is recommended.

That there is a concerted effort to intimidate and weaken the Forest Service is perhaps best shown by the events which took place in several Western cities in 1947 during field hearings of the House Subcommittee on Public Lands. 
These hearings were widely reported in the regional press and in national publications. ${ }^{8}$ Newspaper reporters and other observers who were present have described the hearings as a farce. In several instances, particularly in Rawlins. Wyoming. and Grand Junction, Colorado, the Chairman, Representative Frank A. Barrett of Wyoming, permitted cattlemen to spend long hours in testifying to personal grievances, to irresponsible and inaccurate attacks on Forest Service policies, and to charges that the Forest Service was autocratic and no longer responsible to Congress. Representatives of conservation groups, of city water supply systems, and Forest Service officials were given five to fifteen minutes to present the case for conservation of the ranges. ${ }^{9}$

Representative Barrett was, himself, an active partisan of the stockmen. The Record Stockman, a journal of western cattle growers, has described Chairman Barrett in the role of presiding officer:

"His arms waved; he pointed an accusing finger at the Forest Service section of the huge, tense. crowd. As he finished, his voice quaking with emotion, a large majority of the crowd rose to its feet, applauded and hurrahed." 10

Mr. Benton J. Stong, a representative of the Farmer's Union, unable to present his testimony in the five minutes allotted to him by Chairman Barrett, telegraphed a protest to Speaker of the House Martin that the hearings were "a reflection on the dignity and decency of the House of Repre-

s Bernard De Voto: "Sacred Cows and Public Lands," Harper's Magazine, $197: 108-12$, July 1948 .

Arthur H. Carhart: "Who Gets Our Public Lands," Atlantic Monthly, $182: 57-61$. July 1948 .

Also the Denver Post, the Grand Junction Daily Sentinel, the Ely Times, the Record Stockman, the New Mexico Stockman, etc.

9 Although Forest Supervisors were not allowed to reply to charges in the presence of those making complaints, reports of the Forest Service on specific cases of range deterioration and orders for grazing reductions were entered in the record and printed in the Committee hearings.

${ }^{10}$ As quoted by Bermard De Voto, op. cit. 
sentatives." Presumably, a Congressional Committee holds hearings in order to get at the facts involved in a matter of public policy. It is a public body acting in the public interest. Possibly the Subcommittee on Public Lands forgot these principles at Rawlins, Wyoming, on September 2, 1947.

However, the ultimate responsibility for the unjudicial, pressure-group character of the hearings falls upon the lobbyists rather than the congressman. The livestock trade associations conducted an intensive campaign prior to the hearings to drum up letters and testimony to support the attack on the Forest Service. In their various publications the associations suggested complaints and objections which members might repeat before the committee. Thus the stage was set for Chairman Barrett's management of the hearings. As the evidence shows, he did not miss his cue.

The Barrett Committee hearings provided the most recent climax in the "cold war" of the ranges. Nevertheless, the livestock lobby has continued to operate as before-if not publicly in the West, more quietly and persistently in the cloakrooms and corridors of Washington. The effects of its efforts became evident in October 1949 in a rather spectacular way, when, in the closing days of the first session of the Eighty-first Congress, the American National Livestock Association and the National Woolgrowers Association suddenly attacked the omnibus forest service bill then pending in the Senate.

The attack was led by J. M. Jones of Salt Lake City, Secretary of the National Woolgrowers Association, a prominent lobbyist for the livestock interests. Mr. Jones asserted that the bill would be a further step toward autocratic government-a theme which has been played upon with variations ever since the Barrett hearings. The object of $\mathrm{Mr}$. Jones's attack was a provision of the bill authorizing the Secretary of Agriculture to earmark a part of the grazing fees 
paid by the permittee for the expenses of seeding, re-vegetation, and other range improvements, "when in his judgment such action will be in the public interest." Mr. Jones expressed opposition to the exercise of discretionary powers by Secretary of Agriculture, and maintained that restoration of the ranges should be paid for by congressional appropriations, rather than directly by grazing fees. He also voiced the fear that the Secretary might "arbitrarily" raise grazing fees in order to have more money for reseeding and restoring the depleted ranges of the West.

The stockmen's organizations have been demanding range improvement for years, but Mr. Jones's statement makes it clear that he wants range improvement only at public expense, although the direct benefits of revegetation would accrue to users of the range. Range improvement undoubtedly is advantageous to the general public across the entire United States and should be supported in part by public funds. However, it is disappointing to the public at large to find the livestock lobbyists taking a dog-in-the-manger attitude toward a proposal to earmark a part of the grazing fees for improvement expenditures, merely on the basis of a professed fear of higher charges. Certainly, the cattle growers should not complain about the rates they pay. The grazing fees charged by the federal government on public lands are less than one-half the rates charged by private owners for grazing privileges on privately held lands. ${ }^{11}$

Fortunately, the attitude toward range improvement of the average stockman is much more favorable than that of the lobbyists. Many stockmen have co-operated closely with the federal government in reseeding projects, furnishing from a third to a half of the cost of the project in their own

11 The average grazing fee in 1948 was forty cents per head per month for cattle and ten cents for sheep. No charge is made for the young of permitted livestock, although they increase the forage consumption by about onethird. United States Department of Agriculture, AIS, No. 8o, op. cit., p. 6. 
labor and in the use of their own equipment. These sheep and cattle growers have demonstrated their willingness to contribute to the cost of the range improvements from which they benefit by better forage for their livestock. The general success of co-operative range improvement efforts again indicates that the associations do not really represent the views of a majority of the actual producers of sheep and cattle. As the Denver Post put it in commenting on the opposition of the associations to the 1949 legislation:

"Some people are going to wonder if the big livestock associations are not more interested in harassing the Forest Service than in range improvement." 12

The second basic tactic of the livestock lobbyists is to maintain a constant flow of assertions that the Forest Service is dictatorial in the exercise of its functions. Such charges have been made with increasing frequency in the last few years as the economic pressure for overgrazing has clashed with the growing necessity for more stringent measures to check the cumulative deterioration of forest watersheds.

An illustration from an actual case can best give a clear picture of the tactics employed by the livestock associations to undermine the effectiveness of the Forest Service. Early in 1949 the Regional Forester released a report on the condition of the watersheds in part of the Roosevelt National Forest on the eastern slope of the Rockies. The report showed extensive deterioration of the ranges of the area. Overgrazing and other misuse of the land had caused the original bunch grasses to be replaced by grasses and weeds whose root structures do not generally tend to retain soil effectively. In addition there was extensive growth of cheat grass which is

12 "Strange Antics," an editorial in the Denver Post, October 10, 1949. The forest service bill in question, HR $5^{8} 39$, passed the House and was still held by the Senate Committee on Public Lands when Congress adjourned late in October 1949 . 
highly inflammable, and creates a serious fire hazard in the forests. The report also revealed that severe sheet and gully erosions were prevalent in many places.

In keeping with a policy of proper Land Use Management, the District Ranger took action in the summer of 1949 to bring the stocking of the ranges of the Roosevelt National Forest into harmony with their carrying capacity. The carrying capacity of various ranges was determined after a thorough study of the allotments had been made and all phases of land use had been considered, including grazing, watershed protection, timber production, and recreation.

One of the ranges upon which action was taken in 1949 was the Lefthand Canyon Allotment. This allotment was found to be in a generally poor condition. Much of the area in the Nugget Unit of the allotment was found to be so steep that it was unsuitable for grazing. The other areas, which were suitable for grazing from a standpoint of slope, were in such a poor condition that it was judged to be necessary to close them to use until such time as their ability to produce forage and protect the soil had improved. The permittee on this allotment, Mr. Paul Hummel, accompanied the ranger on a thorough inspection trip of the ranges, during which the difficiencies of the range were pointed out. He was then notified by District Ranger W. S. Beckley that he would be given three years in which to adjust his operation, and that in 1953 the area would be closed to all grazing of livestock.

Mr. Hummel promptly instituted an appeal against this order. The process of appeal is a normal part of the administrative procedures of the Forest Service. The permittee can protest directly to the forest supervisor and beyond him to the regional forester. Should both render adverse decisions, the permittee can carry his appeal to the Chief Forester and the Secretary of Agriculture in Washington. The decision of 
these officials is final, but the Secretary does seek advice on matters of forest policy from a National Forest Board of Review, composed of private citizens professionally competent in Forestry.

It is this purely governmental process which causes the livestock lobby to picture the rancher as helpless in the grip of a hierarchy of heartless, autocratic bureaucrats. For many years, however, the administration of the Forest Service has not been purely governmental. There exist some 800 local grazing advisory boards, whose membership is composed of permittees, who represent the livestock associations. These boards exercise considerable influence in local decisions concerning the proper management of the range. They also serve as an alternative place of appeal for the individual permittee, who can protest restrictions of his grazing permits to the Advisory Board which in turn makes recommendations to the forest supervisor. These are the boards which, according to the livestock associations, should be given legal status with power of decision in matters of range policy.

In the case of Mr. Hummel, the now common practice of by-passing the appeal procedure was followed and appeal was made directly to Mr. Lyle Watts, Chief of the Forest Service in Washington. Mr. Hummel supported his objections to the reduction of his grazing privileges with the opinion of Mr. Lynn Douglas, a retired forest service official, whose expert judgment was that the Lefthand allotment had not deteriorated sufficiently to warrant its closing.

The facts of this case have been made public by the Colorado Rancher and Farmer, weekly journal for stockmen. The editorial comment which accompanies the report of the Hummel case is most interesting:

"Let's draw a parallel case. Let's suppose you are suspected of a burglary, and a police department detective, as 
an expert, decides on the evidence that you are guilty. You hire a private detective and he says, upon consideration of your evidence, that you are not guilty. You can send your private detective's opinion to the chief of police and ask him to consider the matter, but that's as far as you can go. Whether or not you shall be punished for burglary depends upon the decision of the chief of police. You cannot take your case to a judge or jury. None of us would for long endue a system like that.

"In the interest of all concerned with any type of use of the national forest, as well as in the interest of justice for the livestockman using the forest, it is time that some provision be made for neutral consideration and arbitration of the stockman-forest service controversy." ${ }^{13}$

The analogy drawn by the Rancher and Farmer is manifestly false. The permittee is not a criminal trespasser on the property of another. His presence on the public range is sanctioned by a civil contract between him and a public agency. Nor are the personal rights and freedom of the permittee in jeopardy. He is not in danger of being incarcerated or fined. He is more nearly in the position of a tenant whose lease has expired. A permit to graze cattle on public lands is not a permanant and irrevocable right. It is a privilege granted by a civil contract which is terminable under specified conditions by either party.

However, because one of the parties to the contract is a public agency and the other a private individual, it is entirely within the American tradition to surround this particular type of contract with special safeguards for the individual and for the public interest. The Forest Service must be given sufficient authority to protect and conserve the natural resources of the nation effectively; and must be held responsible to the people for the execution of its duties. Equally, the rancher and stockman should be protected

13 Reprinted in the Boulder Daily Camera, October 12, 1949. 
against arbitrary or capricious administration by a government agency. For this purpose formally recognized advisory boards at local, regional, and national levels no doubt are desirable. But such boards ought to represent water and recreation and hunting and fishing, as well as grazing interests. It would be a mistake to permit the boards to be composed exclusively of cattle and sheep growers as at present, or to permit them to have a final voice in the determination of policies for the use and conservation of our public lands, as the livestock lobbyists seem to desire.

The demands of the livestock associations for participation in the regulation of our public range lands irresistably bring to mind Adam Smith's famous advice of more than a century and a half ago. "People of the same trade," he said, "seldom meet together even for merriment and diversion, but the conversation ends in a conspiracy against the public, or in some contrivance to raise prices. It is impossible indeed to prevent such meetings, by any law which either could be executed, or would be consistent with liberty and justice. But though the law cannot hinder people of the same trade from sometimes assembling together, it ought to do nothing to facilitate such assemblies; much less to render them necessary." 14

The current "range war" in the West offers an excellent illustration of some of the typical difficulties which must be met when we attempt to resolve the perennial conflicts among the diverse interests of our society. First of all there is a conflict at the orthodox level of competition among individuals. The rancher on the public range who clings to the old techniques of cattle and sheep culture is in competition with the stock raiser of the feed lot and cultivated pasture. Better and heavier animals result from controlled breeding

14 Adam Smith: The Wealth of Nations, Cannan Edition, The Modern Library, Random House, Inc., New York, p. 128. 
and controlled feeding. Range forage is valuable and should be utilized, but if it is used as it was in the old-fashioned day of the open range the pressure of competition from other stock growers will force the rancher to exploit the range and deplete it.

In the second place grazing is in competition with the alternative uses of the public domain. The Forest Act of 1897 wisely recognized the principle of multiple use of forests, but it did give priority to the protection of watersheds and to timber production. As population has increased in the West, watershed protection and recreation have become increasingly important and grazing and timber production have had to give way. The water produced on the eastern slopes of the Roosevelt National Forest is used for irrigation and domestic water supplies. Its value is estimated to be about $\$ 3$.oo per acre per year. The value of the same land for grazing is not more than ten cents per acre and the timber yield is perhaps twelve cents per acre. The area is heavily used for recreation. Camping, hunting, fishing, picnicing, and similar pursuits are engaged in by thousands of persons, and the financial investment in roads, trails, camp grounds, summer homes, and institutional camps is heavy. These uses complement watershed protection more than they compete with it, and although their annual dollar yield has not been estimated it must be very substantial. The livestock associations profess to recognize these uses of the forest range lands yet, by their present strategy, they attempt to override other uses rather than adapt grazing to a program of integrated multiple-purpose use of forest lands.

The really successful rancher has adapted the techniques of his business to new conditions with better results for himself and better protection of the public domain. Yet some of his professed leaders still cling to the traditions and practices of a bygone era. They continue to think in terms of 
the golden days of Western ranching when cattle was king and the man in the saddle ruled the West.

Such an attitude might be thought of as merely regrettable, if it were not for the fact that it is a source of genuine danger to the future of the West. The ultimate significance of the current maneuvers of the livestock lobbies lies in the threat to our long-established policy of conservation. As timber and forage and water become more scarce, the attacks upon the national reserves by would-be exploiters become more vigorous. It is conceivable that the recent policies of the sheep and cattle associations can gain support from other predatory groups with an eye on one or another of our national resources. The success of the livestock groups could be an opening wedge for the further despoilation of our national wealth. This is the danger which must be avoided. It is a danger which is apparent to the regionalist. The United States is a single integrated economy within which different regions exist with their own peculiar problems and special interests. But the interests of the parts are also the interest of the whole. And the welfare of the national economy depends upon the integration and balance of the various regions which constitute the total national economic organization. 


\section{Chapter 15. -And Sugar ${ }^{1}$}

Although the silver lining in the minerals shortage cloud appears rather badly tarnished, and although there seems to be a wolf or two in sheep's clothing wandering about the ranges of the West, the close observer can take comfort from the fact that the sugar situation is actually sweeter than it seems. For, in the language of the economist, the culture of the sugar beet is now in the midst of a far-reaching technological revolution which is rapidly increasing the efficiency of this important Western industry.

The origins and development of the entire beet sugar industry have taken place within the life span of its founder, Charles E. Boettcher, who died in Denver on July 2, 1948, at the age of 96 . In 1890 , this rising young tycoon, who already had made a fortune in the hardware business during the mining booms in Boulder and Leadville, Colorado, went back to his native Germany for the first vacation in years. On shipboard he met some German experts in sugar beet manu-

1 Much of this chapter is derived from an unpublished thesis written in partial fulfillment of the requirements for the Master of Arts degree: Wilbur T. Billington: The Contemporary Economic Environment of the Sugar Beet (Typewritten; University of Colorado, Boulder, Colo., 1947). 
facture and became interested in the sugar industry. When he returned to this country, he brought with him seeds and machinery and initiated one of the major industries of the semiarid West.

For the sugar beet proved to be well adapted to the economy of the region. Its roots grow vigorously in fertile soil, systematically and regularly supplied with water by irrigation. Its leaves catch the bright sun of the high, cloudless country, and the plant stores up sugar so effectively that its sugar content is high and the tonnage yield per acre more than 30 per cent greater, on the average, than the yield in the Central United States. The beet is also adapted to rotation with grain crops, clover, and alfalfa and thus fits well into the agronomy of the Western farm. Even more important is the fact that the beet top and the pulp and molasses left over from the refining process provide rich feed for animals. Thus, the beet is closely integrated with the livestock industry and dovetails neatly into the Western economy. Finally, the sugar beet is a very important money crop in the West. Over a fourteen-year period in Northern Colorado sugar beets accounted for 25.8 per cent of the gross receipts of a number of representative farms. This was nearly half of the receipts from all crops on these farms. In Utah another study shows that sugar beets grown on 5 per cent of the cultivated land were the source of 12 to 15 per cent of the value of all crops. By contrast, small grains grown on $3^{1}$ per cent of the land produced 22 per cent of the farm income. The income yield of beets on a per acre basis was more than three times as great as the income from alfalfa or grain during the period of this study. ${ }^{2}$

2 R. T. Burdick: Economics of Sugar Beet Production in Colorado. Colorado Agricultural Experiment Station, Bulletin No. 453 (Fort Collins, Colo., Colorado State College, June, 1939), p. 11; and Bion Tolman and Albert Murphy: Sugar Beet Culture: Intermountain Area. United States Department of Agriculture, Farmers' Bulletin No. 1903 (Washington, D. C., May, 1942), p. 2. 
Why then does the sugar beet industry have such a poor reputation? For years the industry has been under steady attack by economists and sociologists. Taussig, Blakey, and Dalton have studied the economics of the industry and found little to praise and much to condemn. The industry has been high-cost and inefficient and has actively lobbied for tariff protection. Sociologists have pointed out that labor conditions in the beet fields are deplorable. The labor is seasonal and migratory. Annual wages are very low and living conditions are bad. Moreover, the beet worker, who with his family spends the summer and fall in the beet fields, returns to the town or city in the winter and almost immediately applies for public relief. The industry, consequently, is subsidized by the local taxpayer as well as by the national government.

These, then, are the problems of the beet sugar industry; and all of them arise from the fact that the cultivation of the sugar beet has required a very large amount of hand labor in the field. Consequently, the cost of production of beet sugar has been very high, and the industry could not have survived without tariff protection against Cuban cane.

\section{The Technological Revolution}

In 1940 a technological revolution in beet culture got under way, and substantial changes in the old picture began to occur. As series of inventions has been developed which eliminate "stoop" labor almost completely and reduce the man-hour requirements of beet cultivation by as much as 80 to go per cent. Money costs of cultivation and harvesting also have been reduced very significantly as a result of the elimination of expensive hand labor.

In order to understand the nature of the mechanization 
process, it is necessary to describe briefly the steps in beet cultivation under the old system. First of all, the seed of the beet grows, not as a single seed, but as a ball of seed from which four or five plants may spring. Also the plant must have room to grow in the soil and on the surface in order to produce the best beets. Thus, the first step in cultivation, after the preparation of the seed bed and planting, is to "block out" the row of young beet plants. Blocking consists of hoeing out some of the plants in the row in order to separate the remaining plants from each other by a distance of ten or twelve inches. Since each seed ball has produced several plants, the "blocks" consist of bunches of seedlings. These bunches are then thinned by hand to eliminate all but the strongest plant and to give it ample room for maximum growth.

When harvest time comes the very long tap root of the beet must be broken and the beet loosened in the soil. This is done by a special type of plow. Then the laborer bends over and picks up the beet, slices off the top with a sharp machete, and drops the beets and tops in piles. Later they must be picked up and thrown into a truck or wagon and carried away. All of these operations described are hand operations, except of course the plowing and seeding. In addition, the beet worker, whose presence is vital in the early stages of cultivation and in harvesting, is kept busy in mid-season by being put to work to cultivate the crop with a long-handled hoe.

All of this now has been changed at every step of the process. In 1930 the United States began to produce its own beet seed domestically instead of importing it from abroad. This change was necessary in order to build up a strain of seed resistant to "curly top," a disease of the plant not found in Europe. As our scientists experimented with disease-resistant seeds, they also began to consider the problem of seed 
types. In the end they developed methods for segmenting the seed so that only one or two plants would germinate. To this development the technicians added improvements in the mechanics of seeding machines so that they have moved a long way toward the ultimate goal of planting a row of seeds which would produce a regular row of single plants. Thus, the use of segmented seed has all but eliminated the need for thinning the rows by hand. Segmented seed was still an experiment in 1941 . By 1948 more than 80 per cent of all plantings used segmented seed.

Mechanical blocking came next. A cultivating machine, operating along or across the rows according to type, chops out alternate sectors of the row, leaving regularly spaced blocks of plants. Now one man, a tractor, and a blocking machine can do a good job of blocking and thinning in most cases, thus displacing the man with the hoe.

Meanwhile, engineers and agronomists had been studying the problem of harvesting. Their chief technical problem was the necessity of topping the beet. Later it was found that machines which worked well in light soils were not efficient in the heavy soils of certain areas. Consequently, several types of harvesting machines have been developed. It is now possible in most areas to drive a beet harvester into a field, dig, top, and load the beets into an accompanying truck in a single operation. The husky Hispano with his swinging machete is gone.

The savings in man-hours and costs through mechanization are astonishing. Where hand blocking and thinning required 27.2 man-hours per acre, complete mechanical thinning requires but $\mathbf{2 . 4 5}$ man-hours. In actual field experiments in Nebraska the cost of harvesting and loading by machine was 97 cents per ton. Harvesting and loading by old hand methods cost $\$ 1.80$ per ton. The cost of growing the sugar beet is shrinking rapidly. 
In all of these developments the agricultural scientist and the engineer have taken the lead, having accepted the obvious challenge of the technical inefficiency of the industry. But the revolution in sugar beets is also an economic revolution. The ever-present economic necessity of reducing costs has hastened invention. Even more important, the general economic environment has encouraged the farmer to adopt the new methods in place of the old without delay. For since 1940, labor has been scarce and wages have risen. The labor shortage has combined with high prices for beets and low interest rates at the banks to encourage the grower to mechanize his operations.

The manpower requirements of war have been, of course, the basic cause of a labor shortage. As we have seen in previous chapters, the Hispano labor of the Mountain West was absorbed by the railroads and shipyards of the $\mathrm{Pa}-$ cific Coast during the war. There is, however, another more permanent factor in the shortage of beet labor. This is the demand for labor growing out of the gradual industrialization of the West. In 1948, under conditions of full employment in the Mountain West, the beet worker has found jobs open to him in manufacturing, communications, and service industries-jobs which in the 3o's were nonexistent. The present state of prosperity and the general move toward industrialization in the West are the factors which at the moment have accelerated the mechanization of beet culture. If these conditions continue for a few more years, the technological revolution in the beet sugar industry will be completed.

\section{Toward a Lower Price for Sugar?}

What then? With lower costs and high efficiency, will the domestic beet sugar industry be able or willing to stand 
on its own feet in world competition? Will the American consumer who has supported the industry for more than a half-century be given the benefit of lower prices for an important and nutritious food? Or will the Sugar Bloc succeed in maintaining protection and high prices with consequent monopoly profits?

These are important questions to which we have no immediate answer. There is, though, the fact that on August 8, 1947, the Congress adopted the Sugar Act of 1948 providing for the regulation of the sugar industry until December 31, 1952. The new act is essentially an extension of the Sugar Act of 1937. It provides quotas for each of the sugar-producing areas, and allots the domestic beet-sugar industry an annual quota of $1,800,000$ tons. By this act a definite share of the American market is reserved for domestic beet sugar producers. (The crude device of tariff protection was abandoned in 1934 in favor of the much more efficient system of quotas). The act also provides for benefit payments to beet growers and for an excise tax on processors of $531 / 2$ cents per hundred pounds to finance the benefit payments. The effect of these measures is estimated to raise the price of sugar in the United States about a cent and a half per pound above the world price. As our annual consumption is about 7 million tons, American consumers pay a premium price of 210 million dollars per year in order to subsidize the beet sugar industry.

The introduction of the Sugar Act of 1948 found the Sugar lobby doing business at the same old stand. The five groups in the industry-sugar cane growers and processors from Louisiana and Florida, sugar beet growers and refiners from Michigan to California, Puerto Rican producers, Hawaiian planters, and the large Eastern refining corporations -all got together and chose a single person to represent them, Mr. Frank A. Kemp, President of the Great Western Sugar Company. The lobby then drafted the bill, utilizing 
for this purpose men from its staff of experts who a few months before had been employees of the United States Government in the Sugar Division, U. S. Department of Agriculture.

The similiarity of the draft bill to the expiring Act of 1937 indicated that the lobby was satisfied with the status quo. Whole sections of the old act appeared in the new bill. Two sections, however, were omitted. The section prohibiting child labor was left out of the first draft, but later was reintroduced. The section of the old act $301(\mathrm{~b})$ which provided guarantees for labor relative to wage agreements and wage payments did not appear in the final draft of the bill. Despite protests the House and Senate Committees reported out the bill without the labor guarantees. The labor provisions were not reinserted in the bill until it came up for debate in the House. There Section 301(b) was added by amendment from the floor of the House.

The influence of the lobby in working for the discard of the labor protection clauses of the bill is clearly indicated in a paragraph from the testimony at the House Committee hearings of Mr. William Glazier, ILWU-CIO.

"It is our understanding that a spokesman for the Department of Agriculture stated here that since all segments of the industry were in favor of discarding this provision, the Department had no objection. However, neither the workers nor the small farmers who are protected under section 301 were ever consulted. They, too, are a part of the sugar industry, and since they are so directly involved, one would have imagined that the Department of Agriculture would have consulted the organizations representing these people. This was not done." 3

The sugar lobby did not want the labor guarantee provision in the bill. Its spokesmen, in the hearings and in debate,

${ }^{3}$ United States House of Representatives Committee on Agriculture: Sugar Act of 1948. Hearings before the Committee on Agriculture. 8o Congress, 1 Session (Washington, D. C., United States Government Printing Office, 1947). 
took the position that the guarantees were not needed now that wages were high and labor scarce. They also argued that it was contrary to the American way to impose government regulation on the industry. Nor did they agree with the counterargument that if the government paid the growers a subsidy it had the right and duty as representative of the general welfare to require the growers and processors to meet certain standards of operation in return for the subsidy. ${ }^{4}$

The sugar men wanted and needed the subsidy; of that there was no doubt. But they wanted it without any strings attached. Apparently the interests of other groups and the general interest of the public at large did not particularly concern the gentlemen of the Sugar Lobby and their friends in the Department of Agriculture and in Congress.

The attitude of the industry to labor is important because it is related to the major problem of technological change which the industry faces. As mechanization takes place total labor costs decline, but hourly wage rates rise as the laborer attempts to gain a share of the increased productivity of the industry. Growers recognize this. At the Denver field hearings on wage rates for the 1948 crop, members of the Mountain States Beet Growers Marketing Association asked for a reduction of $\$ 4$ per acre in wage rates where mechanical thinning was used. The rates requested were $\$ 20.5^{\circ}$ per acre for hand labor and $\$ 16.5^{\circ}$ per acre for labor with mechanical thinning.

The requests were made by $\mathrm{W}$. B. Gress, of Greeley, Colorado, Chairman of the Association's labor committee, whose testimony was reported in the Mountain States Beet Grower as follows:

4 Congressional Record, 8o Congress, 1 Session (Washington, D. C., United States Government Printing Office, 1947), Vol. 93, pp. 8888-89o2 and United States House of Representatives Committee on Agriculture, Sugar Act of 1948 , loc. cit. 
" 'Experience and actual performance in numerous cases have proved that where practical, mechanized operations are involved that the necessary time on the thinning and hoeing operation has been reduced as much as $4^{\circ}$ per cent,' Gress said. He added that taking full advantage of this would cut the price to $\$ 12.5^{\circ}$, but added 'a part of that increased efficiency must be passed on to labor,' and hence the $\$ 16.5^{\circ}$ price was recommended." 5

It is clear from this statement alone that the mechanization of sugar beet culture already is far advanced. Nevertheless, the Sugar Bloc had little to say about the mechanization of the industry during the drafting and enactment of the Sugar Act of 1948. Consequently, the effects of the mechanization of beet culture on costs were not considered in the Sugar Act although it is to regulate the industry for a period of five years-until December 31, $195^{2}$.

Back in $19^{15}$ the tariff expert, Professor Frank W. Taussig of Harvard said:

"The only solid ground for maintaining that protection for beet sugar has been of advantage to agriculture is that of the young industries argument. Ignorance, settled habits and prejudices, unaccustomed methods, the inevitable failures in first trials, all these obstacles may have stood in the way of the beet-sugar industry in its first stages." 6

In his classes Professor Taussig frequently remarked that the infant industries argument for tariff protection was sound economics, but that the trouble with the argument was that the infant never seemed to grow up. The beet sugar industry. has grown up. With mechanization the productivity of the industry per worker is almost certain to be high enough to reFebruary, 1948.

5 "Labor Hearings." The Mountain States Beet Grower, 10:2, January-

${ }^{6}$ Frank W. Taussig: Some Aspects of the Tariff Question (Cambridge, Mass., Harvard University Press, 1915), p. 93 . 
duce the cost of a pound of sugar to a point where the industry can compete with foreign producers. Then the industry will join the long list of American enterprises in which high productivity, high wages, and a high standard of living are accompanied by unit costs of production as low as or lower than those of any other producer anywhere in the world.

The beet sugar industry already is a valued element in the Western economy. As long ago as 1912, Professor Roy Blakey concluded that the indirect advantages of the beet sugar industry probably were sufficient to justify its existence in the United States and its protection by the tariff. ${ }^{7}$ Great improvements have taken place since that time both in the industry and in the agricultural economy with which it is integrated. Moreover, as mechanization develops, the effectiveness of the industry will improve. A mechanized sugar beet industry will contribute to and benefit from the industrialization of the West. Its field workers will be able to earn a decent living, and as their poverty diminishes their education will improve and their contribution to society as citizens will increase. The improvement in the economic status of the Hispano beet worker will greatly aid him in his struggle for the cultural and ethnic equality to which he is entitled.

Such is the future of the sugar beet industry in the United States. It is a future which has been made possible by the experiments of agricultural scientists and the initiative and enterprise of growers and processors. All that remains to be done is to take the final steps for economic independence. What will happen in 1952? Will the sugar beet industry come to its Uncle Sam and say:

"Uncle, I'm a big boy now. Thanks for your help all these years. I've studied hard and worked hard to improve

${ }^{7}$ Roy G. Blakey: The United States Beet-Sugar Industry and the Tariff. Columbia University Studies in History, Economics, and Public Law (New York, Longmans, Green and Company, 1912), p. 265. 
myself. Now I am ready to go out and face the world without your help. Thanks again for that allowance of 210 millions per year. I'll stand on my own feet from now on."

Will something like this happen in 1952? A good many people will be waiting to see. 


\section{Chapter 16. The Betrayal of the Western Liberal Tradition}

By 1896 the tradition of a Western liberal spirit was well established. Nearly a century had passed since Jefferson led the first successful revolt of the frontier against the established society. Jackson and Lincoln in turn led subsequent revolts to victory, while in the intervening years many a skirmish was won or lost in the continuous conflict over the vital issues which separated the interest of the East and West.

In essence Western liberalism, throughout the period, stood for economic expansion and free individual enterprise. It opposed the conservative tendencies of the Eastern owners of capital and objected to the efforts of Eastern investors to retain control of new ventures toward the West. It demanded a voice in government, not only to help secure its economic goals, but also to reaffirm the American belief in the principle of government by all the people.

As time went on and the frontier moved westward, these basic principles were reflected in new issues, and new leaders rose to champion the West of the moment. For Jefferson one of the chief issues was personal liberty as opposed to the militarism and centralized control embodied in the Alien and 
Sedition Acts. The economic issue of expansion gave Jefferson the support of the "back-country grain growers" and thus insured his election. His decision to purchase the Louisiana Territory against widespread Eastern opposition is a perfect example of the conflict between expansionism and conservatism in economic policy. For Jackson the struggle against the Bank of the United States was the issue which, above all others, embodied the East-West conflict over economic developmental control.

After the Civil War the economic issues again emerged sharply, unclouded and unobscured by the slavery question. The Western farmers soon found that the new railroads, which had promised so much, were not an unmitigated blessing. The fight against high rates and against rate discrimination was largely responsible for the rise of the Populist Party and the Granger Movement. And the farmer-debtors soon discovered other enemies in the monopoly practices of "the trusts" and in Wall Street's monopoly over investment capital.

In the 1890 's the agrarian dissenters of the Western farm states found natural allies in the proponents of free silver, and both groups found a leader of stature and ability in William Jennings Bryan. Once more the historical pattern of Western revolt was being repeated. Bryan stood for economic expansion, for cheap money, and a ready flow of capital for new investment. He stood, also, for human rights, and his party was much more sympathetic than the Republicans to labor.

Nevertheless, by this time the frontier West was no longer able to triumph over the East at the polls. The East was now too extensive in territory and its advantage in population too large to be easily defeated. Moreover, the Western farm states of the day, such as Kansas and Nebraska, were beginning to feel the effects of the American industrial revo- 
lution and the penetration of Eastern capital. In this group of states local business reacted against the Democratic program in sympathy with their Eastern allies, and the Republicans lost little ground. ${ }^{1}$ In these states by 1896 the issue of East vs. West was no longer simple and clear. The sectional conflict of interest had given way, and a new set of interestgroupings based on economic functions rather than upon geography was being formed. The frontier was no longer able to enlist enough support in the East to achieve victory at the polls. The tide of industrialism was rising with great rapidity. The prestige of the industrialist was high, and his views on economic issues appealed to many. On the other hand, the power of the Eastern allies of the frontier - the farmer and laborer-was weak and diffused. The agrarian had lost prestige in the new industrial society and was decreasing in numbers.

Labor was not to gain real cohesiveness or the strength of organization until after 1930. Without Eastern allies, the West was destined to defeat. The era of the frontier revolt was gone.

\section{The Eclipse of Western Liberalism}

Bryan tried again in 1900, but the spirit and fire of '96 were dampened; and in the last fifty years there has been no new attempt to stage a Western liberal revolt. It is true that Western liberalism has found expression from time to time in strong support of such liberal proposals as woman suffrage or the popular election of senators. But in the economic sphere the liberal spirit has gone into eclipse. The mass, popular support of Western interests through the use

1 V. O. Key, Jr.: Politics, Parties, and Pressure Groups (New York, Thomas Y. Crowell Company, 1947), pp. 250-1. 
of the party campaign and an appeal to the majority of the people at the polls has disappeared. In its place, the championship of Western interests and of the Western point of view has gone underground into the hands of pressure groups and blocs.

The result has been the betrayal of the West and of the entire nation. For the special-interest group is not concerned, except incidentially, with the regional welfare or the national welfare. The typical bloc is based on a functional interest, and, consequently, the representatives of this interest in the various sections become allied in a single over-all grouping. The Western miner combines with mineral producers and processors in other regions. And the various mining areas are tied even more closely together by corporate ownership and control which is national and international in scope. The Sugar Bloc is composed not only of Western beet growers and processors but also of the large Eastern cane refiners and the cane growers of Louisiana and Florida. Sometimes a bloc of this kind indulges in internecine quarrels, but at the hearings on the Sugar Act of $194^{8}$ these diverse interests presented a united front and were represented by a single individualMr. Frank A. Kemp, president of the Great Western Sugar Company. The wool and beef interests of the West also belong to national associations, and these in turn form part of the larger Farm Bloc. The fight for a wool tariff, described above, was not led by a Westerner but by Representative Hope of Kansas who gave as his reason that wool was but one example of many agricultural products requiring protection, and just happened to come up first.

There continue to be sporadic outbreaks against discriminatory freight rates in the West, and occasionally the wool or cattle associations will attack the railroads on this score. By and large, however, the interests of the railroads are looked after very well by Western chambers of commerce and 
similar interest-group organizations. This fact helps to explain the failure of the attempt to create a South-West coalition, which is described in the following chapter.

The same situation prevails in the field of electric power. The Western utility companies are closely associated with the national utilities corporations, both directly and through a mutual community of interest. Any attempt to set up municipal ownership or any advocacy for the development of the region's unutilized hydroelectric power potential at once arouses a powerful local opposition backed by national organization.

These Western supporters of the functional blocs thoroughly permeate the regional society. The members of the special-interest groups form the nucleus of organization because of their immediate pecuniary interest in the success of the bloc. But they are joined by large numbers of the general business and professional community where a similar outlook and a similar ideology are usually found. ${ }^{2}$ Together these two classes of citizens are able to exert a very strong pressure on

2 "Ralph L. Carr, ex-Governor of Colorado and private utilities attorney, has long been on record as an opponent of TVA and other public power developments. . . .

"In 1945, Carr, acting as chairman of the national resources committee of the Chamber of Commerce of the United States, requested a study to be made by that organization's natural resource department. The result was the 'Green' report, so-called because it was made by one C. J. Green, an accountant formerly with FPC.

"On June 18, 1946, Senator Lister Hill discussed the Green report and its implications on the floor of the Senate, as follows: 'So what do we have with respect to the Green report? We have Ralph L. Carr, the utility lawyer, asking the Chamber of Commerce to ask Ralph L. Carr, the chairman of the National resources committee of the United States Chamber of Commerce, for an unbiased report on the TVA.'

“On May 23, 1948, newspapers announced Carr's appointment to the Natural Resources Committee of Herbert Hoover's commission on organization of the executive branch of government.

"Thus, on the board which would 'reform' the government and would influence the shape of the brave new world, we have the backwardlooking, biased Mr. Carr occupying a key position. He does not quite fit our definition of 'reformer." "-from "Reform-Which Way?" Rural Electrification, 10:27, July, $194^{8}$. 
public officials at all levels of government-city, state, and national-so that the viewpoint of the bloc is well represented in the determination of public policy. There is, by contrast, little or no representation of the viewpoint of the West as a region. It is only when a bloc is predominately localized that the sectional or regional interest becomes important. Even then, the functional interest may be of great significance. In the essentially Western field of reclamation, for example, the National Reclamation Association, which started out as a kind of public lobby for Western development, has come to be dominated over the years by such special-interests as the railroads and the utilities. Today the Association's activities reflect merely the interest of private groups of this kind, even to the extent of outright opposition to policies which clearly would benefit the West as a region.

It is for reasons of this kind that the regionalist cannot find much to approve in the activities of the pressure groups, for the pressure group at best represents a minority interest -even in the region; and by the nature of our political system the minority group is able to exert an influence greatly out of proportion to its size. Moreover, the pressure group, in contrast with the political party, operates undergroundin the cloakroom and cocktail lounge. It does not seek to win elections nor to persuade the majority to adopt the policies it espouses. ${ }^{3}$ It seeks to influence legislators and administrators between elections and to secure advantages for itself in those areas of policy which lie between the major points of orientation which presumably have been determined by the mandate of the people.

All this should not be taken to imply that the pressure group is purely and simply an unmitigated evil. The pressure group, as many expert observers have pointed out, has

\footnotetext{
Rinehart, Inc., 1942), Ch. 8.
}

3 E. E. Schattschneider: Party Government (New York, Farrar and 
grown up to fill a vacuum in our political system. ${ }^{4}$ Its help in forming legislation for various types of economic control is invaluable as long as Congress is not equipped with its own independent research staff. Even more important is the fact that in a democracy the activity which is to be regulated or controlled in the social interest can only be controlled effectively "with the consent of the governed;" and the opinion of the group about what is workable or unworkable legislation must be sought by the legislator and administrator.

On the regional level, the representation of the region by the pressure group is better than no representation at all. However, the divided allegiance of the group is almost fatal to genuine regional representation in national policy. The danger here is at least as great as the national danger that the bloc will pursue its own ends with disregard for the national well-being. Too many examples exist for one to doubt the reality of both these dangers. Thus, while the bloc may serve a useful purpose in regional economic policy determination, it seems preferable for the region to place its main reliance on the use of the party system and to make its appeal to a majority decision of the people at the polls. This is what the West did throughout the nineteenth century. At first it was successful, but in 1896 a major effort failed to win the majority. Can the West hope for success if it tries again in the second half of the twentieth century?

\section{Toward the Rebirth of the Western Liberal Movement ${ }^{5}$}

It is not in the province of the political economist to attempt to predict the nature of future political trends in the

4 Loc. cit., and V. O. Key, Jr., op. cit., pp. 250-1.

5 In this section it is necessary to expand the definition of "the West" to include the seventeen Western states for reasons which will be obvious to the reader. 
United States. There are, however, certain directions in economic change about which one can speak with a fair degree of certainty. These changes provide a likely basis for future political issues, and also indicate the probable sources of the strength of the political movement which they may inspire.

If a new liberal political movement does develop in the West, it seems probable that it will be based on three major economic issues: economic expansion, the decentralization of economic control, and the conservation of natural resources.

The issue of economic expansion was the primary issue in the Western revolts of the nineteenth century. Then it meant free land, cheap money, and adequate transportation facilities. In the decades immediately ahead the question of economic expansion will center around the method and rate of development of the West's untapped resources-land, forests, minerals, water, hydroelectric power, and recreation. In the Mountain West awareness of the relative underdevelopment and "skipping over" of the region will become widespread once the present boom subsides. In the Pacific West great opportunities for future expansion still exist despite the very rapid growth of the region during the present decade. In both regions expansion is sure to be a very popular issue. The challenge of unused resources is visible on every hand throughout the West, and the Western spirit is not one to resist such a challenge.

Closely allied with the desire for resources development will be the question of who is to control the resources and secure the fruits of their exploitation. Here the West has two ready-made issues at hand. The first is the old issue of Eastern corporate domination of Western resource exploitation. Proposals for freight-rate revision, the regulation of monopolies, and measures for providing adequate credit facilities for local enterprise can continue to occupy the stage in this sphere. The big question is whether the West can 
break the alliance of its own pressure groups with Eastern interests in order to make these issues genuine centers of controversy. In some ways the economic movement toward industrial decentralization can aid the West in fighting out this issue. For, as our national corporate agglomerations make larger investments in the West, the regional conflict will become of less importance to them, and their present bias in favor of the Northeast will diminish. On the other hand, if the rate of private development appears to be too slow, the present scattered mutterings of discontent might well coalesce into an explosive public issue.

In either case, the second issue of economic control, that of the role of government in the expansion of the West, is certain to arise. The development of large-scale reclamation and power projects is already a function of government in the West. The large percentage of the total land area in government ownership is another factor in defining the sphere of government. At present these manifestations of the expansion of government are under attack by conservative groups in the West. The attack on public lands policy by private individuals already has been mentioned. ${ }^{6}$ Others have raised the issue of "states' rights" either out of genuine conviction or from a desire to protect various types of corporate ownership.

But the issue of the future will not be the old issue of "strong" vs. "weak" government. Western resources cannot be developed to the optimum in the twentieth century without a major contribution to the process by government. The real issue will be the question of what type of government we are to have. More specifically, the debate will concern the methods and administrative techniques by which government can be decentralized regionally and made more sensitive to the needs and desires of the people. On this issue the liberal

${ }^{6}$ See Chapter 15. 
position is now clear. The Western progressive will welcome the more active participation of state and local governments in resources development, and the utilization of such administrative tools as the interstate compact. But in the light of past accomplishments these agencies must be judged inadequate to the task. With the example of TVA before him, the Western liberal has become an advocate of valley authorities on the Columbia, the Missouri, the Colorado, and the Arkansas. This is the issue which will be fought out in public forums and congressional committee rooms in the years immediately ahead.

The third major issue which very well may stimulate a rebirth of the Western liberal spirit is the issue of conservation. The idea of economic expansion is popular and easy to grasp; and it had an appeal in the nineteenth century just as it will appeal in the twentieth. However, in the United States conservation is mainly a twentieth-century idea. In the early days of the century when the conservation thesis was advanced by Pinchot and Roosevelt it was a new idea which had its origins and support among intellectuals. But today nearly everyone in the West is a conservationist. The cattlemen are sincere when they say they believe in conservation. They do. They must. Every Westerner-judge, or teacher, or banker, urbanite or small-towner-lives closer to the realities of nature than do the great majority of Easterners. The Western farmer and rancher know Nature's power and her limitations more intimately than they know their own faces in the mirror; and even the city-dweller in the West cannot escape the awareness of his dependence upon limited, natural resources. Conservation can easily become a great, rallying, popular issue in the West. A few more raids like that of the minority of cattlemen against the public lands or another cycle of drought can supply the spark which will set it off at some indeterminate but certain date in the future. 
The Western liberal of tomorrow and today has at his hand three great economic issues around which to build a liberal program-economic expansion, economic control, and conservation. Moreover, these issues are important enough and significant enough to enlist popular support across the nation and to provide the stimulus for the coalition of Western groups into an active working alliance. It is obvious that these three issues are not merely local issues, but national issues of first rate importance. There is still room for expansion and investment everywhere in the United States. In the South the problem is one of resources development very similar to the problem of the West. In urban areas slum clearance and city planning alone represent a colossal task. Another depression or slowing-up of the investment process will precipitate this issue into certain prominence. Conservation also is a matter of universal concern. The problem of conservation is coming to the fore everywhere as world population growth presses against the world's resources. The combination of the two first-rank issues of resources development and conservation immediately raises the companion issue of control. Who is to take the long view? Who pays the costs and shares the benefits? How can government be made responsive to the people who live in a particular region and work with a particular complex of resources. These are national questions, not regional ones. They can command national attention even if the West is the first to raise them out of a consideration of its own special problems.

A new liberal movement in the West can be expected to gain national support on basic issues once the movement is under way. But can it find the indigenous strength to create a movement broad enough to assume the proportions of a political revolt? Here again prediction is difficult, but at least it is possible to say that the economic groups which might form such a revolt do exist in the region, even today. 
First of all there is the farm group. A twentieth-century liberal movement in the West cannot be entirely agrarian, but it necessarily must contain an agrarian element of major proportions. It is true that many of the West's farmers and ranchers are allied with special-interest groups of the type described above. However, it is also true that the most liberal and most aggressive of the three major farm associations is largely a Western organization. The strength of the National Farmer's Union (Farmers' Educational and Co-operative Union of America) lies west of the 98 th meridian. Its headquarters are located in Denver, Colorado, and its president, James Patton, is a former Colorado farm boy and a man of broad, liberal outlook.

Equally important, the Farmers Union has sought an alliance with organized labor on many issues. Its position is that farm prosperity and the prosperity of the working man are intimately related, and that high-level employment means high-level consumption. This point of view has found concrete expression in the sponsorship by the Farmers Union of the Employment Act of 1946, in itself a significant liberal reform.

The second element in a Western liberal movement is organized labor. The possibilities of a Western farm-labor alliance exist on the labor side as well as in the attitude being promoted by the Farmer's Union. West Coast labor is well organized and aggressive. In the Mountain West, as we have seen, organized labor has a tradition of militant liberalism which antedates the rise of the major unions in the industrial East. ${ }^{7}$ It is true that up to now the agrarian and labor groups in the United States have not succeeded in uniting on the common ground of a positive program of liberal reform. In the past their alliances have been temporary and directed against a transitory enemy. In the future, however, it may be

${ }^{7}$ Chapter 2. 
different-at least in the West. The three fundamental issues of Western liberalism should appeal directly to the basic interest of labor. Economic expansion in the West means the industrialization of the area, more factory jobs, and greater strength for the unions. Consequently, union members should be able to see the benefits which reclamation and public power will bring to them. Conservation of resources is less immediate in its appeal, but it is a subject which is by no means unfamiliar to the Western urban worker who has seen the effects of floods and drought in town as well as in the country. The issue of control, also, is one in which the unions have a vital interest, and the idea of governmental decentralization has an appeal for every Westerner. On these fundamental issues the common interests of farmers and laborers are so apparent that it may be possible to overcome the obvious differences in interests and attitudes which heretofore have kept the two groups from forming a permanent union.

The Western liberal program also should be able to attract the support of consumer and business groups in the region. Consumers in general, and municipal ownership groups in particular, should find the possibilities of low-cost electricity most attractive. Small business, also, would benefit from lower power costs. The investment opportunities of the program should have much to do with gaining support for the movement from business groups. For, although the economic expansion program would necessarily assign a large role to public investment, the possibilities for private investment undoubtedly would be increased greatly.

The numerous groups interested in the conservation of wild life and in the various aspects of recreation also would find much to approve in a program which would develop highways and recreation facilities and maintain wild life reserves as an integral part of resources protection.

All these factors, it must be remembered, exist in $195^{\circ}$ 

as potential sources of strength for a possible rebirth of liberalism in the West. Against them must be set the actual and present strength of the Western pressure groups and their Eastern allies. For fifty years the blocs have stifled Western liberalism and perverted the regional and national interest. It remains to be seen if the Western liberal movement can shake off its incubus, and once more successfully appeal to the majority of the national electorate through the democratic mechanisms of the party system. 


\section{Chapter 11. Regional Rivalries and Regional Alliances}

In recent decades the defense of the regional interests of the West has broken down almost completely before the onslaught of the pressure groups. As we have seen in the previous chapters, the inter-sectional alliances of functional interest-groups have dominated the Western scene, and the interests of the region have been strongly represented only when they happened to coincide with the interests of one or another of the pressure groups.

Now, however, the situation seems to be undergoing a significant change. As recently as 1943 a definite attempt to create regional solidarity in the Mountain West failed completely, but by 1948 there were several signs of the rise of a regional spirit among the Mountain states. Interestingly enough, one of the most important indications of the new spirit has appeared in an area of controversy which has been one of the most frequent sources of intra-regional disunity in the past-the dispute over the problem of water.

\section{The Struggle over Water}

Water is precious in the semi-arid West. Its possession on the land often means the difference between good crops 
or bad, prosperity or penury. Consequently, the right to take water from a stream is one of the most valuable pieces of property which exists in the West. These water rights are protected by the laws of the state, and since the earliest territorial days the state has played an important role as the adjudicator of disputes over water rights.

It is only a step from the state's protection of the water rights of the individual to the protection by the state of the rights to water to all of its citizens vis-a-vis the citizens of another state. The history of the West is replete with conflicts among the states over the waters of the streams which rise in the Rockies and flow through the semi-arid states on their way to the Atlantic or the Pacific. These conflicts are classic examples of the protection of a sectional interest by means of the direct use of the instruments of politics and government.

The basic cause of conflict is, of course, the desire of each state to further its own interests by securing a larger share of the stream flow for its citizens. Yet the river by its very nature is contemptous of state lines, and the best use of its waters is determined fundamentally by the physical and economic characteristics of the drainage basin-stream flow, precipitation, topography, soil fertility, climate, population, transportation facilities, and markets. Thus from the beginning it has been necessary to treat the river and its drainage basin as a unit in order to find a reasonable and acceptable solution to the problem of utilization of the river and its waters.

The device which eventually was worked out as a means of achieving a solution is the interstate compact. In such a compact an agreement is reached among the states through which the river flows, each state being allocated a certain amount of water and obligating itself to deliver a specific volume of water to the neighboring state. Sometimes, of course, the states cannot agree; and then the conflict is taken 
to the Supreme Court by means of a suit of the one state against the other. Kansas and Colorado, for example, were involved in litigation with each other over the division of the waters of the Arkansas River for a period of forty-two years.

The Interstate Compact is an example of the regional approach to a problem of resources development, while recourse to the courts by individual states is a very good example of a dog-eat-dog sectionalism. In the case of the compact, attention is given to the physical and economic characteristics of the drainage basin, and the water is apportioned for specific projects and uses. The resulting division is then computed on the basis of state boundaries-so that the share of each state is derived from the consideration of basic factors and not determined by political log-rolling. The appeal to judicial authority, by contrast, is predicated on the thesis that one state has been injured by the actions of another. A state believes that another state is appropriating water which rightfully belongs to its citizens-or which it claims for its citizens or intends to claim for them-so it appeals to the courts to protect its claims. Legal principles and methods are substituted for economic analysis, and forty years later the matter is still under litigation.

The present controversy over the Colorado River admirably illustrates the difference between the regional and sectional attitudes in the West. It also provides an example of the recent growth of a regional spirit in the Mountain States. In addition, as was pointed out in Chapter 3, the ultimate division of the waters of the Colorado will greatly affect the regional balance between the Mountain West and the Pacific Coast region for many years to come. Thus, because of its implications for the political and economic future of the nation, the solution of the Colorado River controversy is a matter of interest to all Americans. 
The fundamental issue in the struggle over the Colorado is the desire of the rapidly growing Southern California area to secure an adequate water supply at the expense of the slowly developing Mountain West. This struggle has been going on for at least thirty years. In 1922 the Colorado River Compact was signed by the seven states of the Colorado Basin as a result of the pressure of California for more water. Its terms divided the river into a upper and lower basin and allocated the water between the two basins without specifying the share of each individual state. ${ }^{1}$ The agreement cleared the way for the construction of Boulder Dam and the AllAmerican Canal, thus permitting California to increase its water supply immediately. It also assured the Upper Basin states of a supply of water much in excess of the amounts they were using in 1920 and presumably adequate for their future needs. The agreement was soon ratified by the legislatures of six of the seven states. ${ }^{2}$ Its terms appeared to be generally acceptable and the Compact was regarded as a model example of the regional approach to the utilization of a basic national resource.

In 1947 California once more felt compelled to take positive steps to secure additional water for the mushrooming population of the Los Angeles-San Diego area. Finding the Compact too restrictive and realizing that Arizona and the Upper Basin states might soon make use of the unappropriated water allocated to them in 1920, California has attemped to break the compact and throw the issue of water allocation into the courts. To this end a resolution was introduced in the First Session of the 8oth Congress by Senator McCarran of Nevada which, if adopted, would provide that

1 A small allocation also was made to the Republic of Mexico.

2 California, Colorado, Utah, New Mexico, Wyoming and Nevada had ratified the Compact by 1922 . Arizona did not ratify until 1944 . 
Congress ask the United States Supreme Court to rule on the issues in the current water disputes on the Colorado. ${ }^{3}$

The repercussions to California's drive for additional water were not long in coming. As soon as her intentions became apparent, the states of the Upper Basin hurried to make plans for the settlement of their long-standing dispute over the division of the water of the upper Colorado and its tributaries. In July 1948 representatives of Colorado, Wyoming, Utah, Montana, and Arizona met in Vernal, Utah, to draw up a new interstate compact apportioning the water of the Upper Basin. Ever since 1922 these states had been unable to agree on a fair division of the water, and lack of agreement had delayed the initiation of any major reclamation and power projects in the entire area. However, the threat of California's encroachment drove the Upper Basin states together in league against the common enemy.

The compact commission meeting lasted over two weeks. At first it looked as if agreement were impossible. The five states had a total of 7,500,00o acre-feet of water to divide among them. The claims which they brought to the meeting added up to 8,783 ,ooo acre-feet, and each state was determined not to yield an inch. In the end, however, they did agree and an equitable division was worked out.

The agreement was a triumph of careful planning and skilled negotiation and the climax of the six previous meetings which had been held in 1947-8. The delegations of experts and the press of the region gave much credit for the success of the meeting to its chairman, Harry W. Bashore, former Commissioner of Reclamation, whose compromise formula to break the deadlock was accepted. ${ }^{4}$ No credit at all

3 United States Senate Joint Resoultion No. 145, 8oth Congress, 1 Session: To authorize commencement of an action by the United States to determine interstate water rights in the Colorado River. A similar resolution was introduced by Senator McCarran in the 81st Congress.

4 The Denver Post, July 21, 1948. 
was given to the members of the California State Water Resources Board who, despite their absence, probably did more to insure the success of the meeting than anyone who was present throughout the extended negotiations.

The negotiations at Vernal resolved the issue among the five states of the upper basin, and ratification of the compact by state and federal governments quickly followed. The compact is a significant contribution to the regional development of the Mountain West. The signature of President Truman on the compact in April 1949 gave the Bureau of Reclamation the signal to embark on a series of major projects in the basin. ${ }^{5}$ Plans already exist for storage reservoirs which will stabilize water supplies for irrigated lands in Colorado, Wyoming, and New Mexico and provide a regular flow to the Lower Basin in years of variable rainfall. Because in 1948 the Upper Basin states actually were using only about one-fourth of the water allocated to them, the opportunities for expansion are enormous. These opportunities could not be realized until the states of the Mountain West became willing to approach their mutual problem in a spirit of regional cooperation. This is the real significance of the Vernal meeting.

There is, of course, a present danger. Regional integration is now possible in the Upper Basin, but as long as California persists in her current attitude the larger basin of the Colorado is split into warring, sectional halves. The McCarran resolution is a backward step in resources development. In effect it would abandon the regional approach to water utilization and revert to the old era of tooth and claw. Instead of a division of the water based on the optimum use of the scarce supply on a region-wide basis-it would allocate

5 In 1947 the Bureau ruled that it could make no future plans for projects in the Colorado basin until the dispute over allocation among the states was settled. 
the stream flow on a basis of power politics and sectional logrolling in an overworked Congress. Such an eventuality cannot be in the national interest, but only in the interest of the pressure groups whom Senator McCarran represents so effectively.

\section{The Water Issue and the MVA}

Unfortunately for the Mountain West, the progress on the Colorado has not been matched on the Missouri. Here the struggle for water is just as intense as on the Colorado, but the circumstances are very different. The Missouri is one of our largest rivers; and, although it rises in the semi-arid West, ultimately it crosses the ninty-eighth meridian to flow through the well-watered farmlands of Iowa and Missouri. Regional development is further advanced in the Missouri Valley than in the Colorado Basin. On the Missouri, however, a divided authority exists between the Corps of Army Engineers and the Bureau of Reclamation; and it is out of this rivalry that the struggle over water arises, primarily as a conflict between navigation on the lower river and irrigation in the upper valley.

This conflict might be described as a sectional conflict between the irrigation states "West of 98 " and the states of the lower valley. Actually the downsteam states are not too much interested in navigation. River freight does have certain advantages, but it is not a vital issue. The real cause of the conflict arises from the historic interest of the Army Engineers in navigation and from the lack of a unified and integrated program of regional development for the Valley as a whole.

The story of the attempts to create a regional program in the Missouri Valley is a long one which has been reported 
from many sources in recent years. ${ }^{6}$ The Missouri Valley has been one of the nation's depressed areas for the last two decades. Tremendous floods have taken scores of lives and destroyed millions of dollars of property. Droughts and worn-out soil have made farming precarious and unprofitable. Economic opportunities have declined; and, rather than face chronic unemployment and frequent crop failures, thousands of the people of the Valley have migrated to regions where greater possibilities seemed to exist. Five states in the Valley-Montana, North and South Dakota, Kansas, and Nebraska-have been losing population since the early ' 30 's. Of course, conditions in the Missouri Valley have improved during the war-at least temporarily; but the decline of the region relative to other parts of the United States continues.

Gradually it became clear to the people of the Valley that something had to be done; and, logically enough, there emerged the idea of establishing a Missouri Valley Authority to plan for and develop the resources of the region. Senator James E. Murray of Montana was one of the leaders in the Valley who believed in the soundness of this solution. Accordingly, in 1945 he introduced a bill in the Senate during the 79th Congress which provided for the creation of an MVA patterned after the TVA.

His bill was defeated in committee in 1946 and sidetracked again in 1948 and 1949 , but the fight for an MVA is still going on. The opposition to the MVA is in part ideological and in part manipulated by the pressure groups. In ad-

6 The best single work is that by Rufus Terral: The Missouri Valley (New Haven, Conn., Yale University Press, 1947). Excellent brief discussions include Joseph Kinsey Howard: “Golden River," Harper's Magazine, 190:511-23, May, 1945; C. Herman Pritchett: "The Transplantability of the TVA," Iowa Law Review, 32:327-38, January, 1947; Morris Llewellyn Cooke: "Plain Talk About a Missouri Valley Authority," Iowa Law Review, 32:367-9o, January, 1947; and Wesley Price: "What You Can Believe about MVA," Saturday Evening Post, 21:22-4, January 19, 1946. In addition, numerous news stories and special feature articles have appeared in the St. Louis Post-Dispatch in recent years. 
dition, the Corps of Army Engineers and the Bureau of Reclamation have attempted to forestall an MVA in order to retain control of the development of the Missouri in their own hands. To this end they have succeeded in burying their own sharp differences and creating the compromise Pick-Sloan Plan for the development of the Missouri River.'

The great difficulty is that the Pick-Sloan Plan is not a true regional plan, and it is incomplete and inconclusive in numerous important respects. It lacks the integration and co-ordination of a genuine valley development plan. It is a hasty compromise between two partial, contradictory, rival plans. This has been apparent to students of the Valley problems for some time, but the extent and seriousness of the waste and mismanagement of the Pick-Sloan Plan was not fully revealed until the 1949 report of the Hoover Commission on the organization of the Executive Branch of the Government. Seldom has a governmental enterprise been damned so thoroughly or conclusively as in the special case study of the Missouri Basin prepared for the Commission by the Task Force on Natural Resources. The task force found that:

"there is no program for the valley as a whole."

"the programs were planned in many of their phases without adequate data on soil fertility, irrigability, water amount and quality, consumer acceptance of irrigation, and other basic economic data."

"Jurisdictional jealousy is inevitable, and costly as well, so long as such organization separation is produced. Friction therefrom operates as a perpetual drag on efficiency and as a stimulator of group and sectional competition for favor and undue influence."

${ }^{7}$ Named for the principal authors of the separate plans of the two agencies: General Lewis A. Pick, United States Army, Corps of Engineers, and W. G. Sloan, United States Bureau of Reclamation. 
"Plans are made which see only parts of the whole situation, and wasteful expenditure of funds results, while the total objective which might have been attained is only partly realized." ${ }^{8}$ If the development of the Missouri Valley is left to the Pick-Sloan Plan the end result will be a hodge-podge of partial and incomplete projects which, in sum, fall tragically short of realizing the potential productivity of this great region.

Equally bad is the fact that the Pick-Sloan Plan breeds sectional conflict within the valley itself. The plan is not only considerably less than an integrated program for regional development, it is also inconclusive in its attempts to deal with the question of the division of the waters of the Missouri. Neither the Bureau of Reclamation nor the Army Engineers has determined how much water will be required by the projects of either agency, or by the Pick-Sloan Plan itself. Consequently, the people of the upper valley fear that the major flow of the river may be used to maintain a navigable channel in the lower river, rather than for irrigation in the semiarid upper basin.

Unfortunately, there is a good deal of justification for this fear. It is true that the Flood Control Act, Public Law 534 of the 78 th Congress, 2nd Session, contains in Section 1(b) the following safeguard, usually called the O'MahoneyMilliken Amendment:

The use for navigation, in connection with the operation and maintenance of such works herein authorized for construction, of waters arising in States lying wholly or partly west of the ninety-eighth meridian shall be only such use as

${ }^{8}$ Leslie A. Miller, and others: Organization and Policy in the Field of Natural Resources (A report prepared for the Commission on Organization of the Executive Branch of the Government; Washington, D. C., United States Government Printing Office, 1949), pp. 138-9.

Commission on Organization of the Executive Branch of the Government: Reorganization of the Department of the Interior (Washington, D. C., United States Government Printing Office, 1949), p. 29. 
does not conflict with any beneficial consumptive use, present or future, in States lying wholly or partly west of the ninetyeighth meridian, of such waters for domestic, municipal, stock water, irrigation, or industrial purposes. ${ }^{9}$

On the other hand, Congress in 1945 authorized the Army Engineers to construct and maintain a 9 -foot navigation channel in the Missouri from Sioux City, Iowa, to the mouth of the river. This the Engineers are planning to do. There is, therefore, an apparent contradiction between the two acts since the authorizations would seem to call for more water than the river produces in most years. ${ }^{10}$

The crucial question is whether there is enough water for both irrigation and navigation. Many competent engineers do not think that the supply is large enough. ${ }^{11}$ Irrigation claims under the Pick-Sloan Plan would require some 9.22 million acre-feet of water per year. Maintenance of the navigation channel during an eight-months navigation season would require at least 14.5 million acre-feet. During the so-called "dry cycle" such as that from 1929 to 1940 the river produced about 16.2 million acre-feet per year. Since 14.5 plus 9.22 equals 23.72 million acre-feet, it would be necessary, beginning with the first dry year, to draw 7.5 million acre-feet from storage reservoirs to satisfy the claims of both navigation and irrigation. After eight years the reserve sup-

- United States Statutes at Large, Vol. 58, Part 1. Public Law 534, Chapter 665,78 Congress, 2 Session: An Act Authorizing the Construction of Certain Public Works on Rivers and Harbors for Flood Control, and for Other Purposes (Washington, D. C., United States Government Printing Office, 1945), p. 889 .

${ }_{10}$ United States Statutes at Large, Vol. 59, Part 1. Public Law 14, Chapter 19, 79 Congress, 1 Session: An Act Authorizing the Construction, Repair, and Preservation of Certain Public Works on Rivers and Harbors, and for Other Purposes (Washington, D. C., United States Government Printing Office, 1946), p. 19.

11 The figures cited here are contained in a report, The Big Missouri: Hope of Our West (Report No. 2; Washington, D. C., Public Affairs Institute, 1948), signed by Morris L. Cooke, consulting engineer; David Cushman Coyle, consulting engineer; Walter C. Lowdermilk, conservation engineer, and J. Russel Smith, geographer. 
ply of water in storage would be exhausted, and either irrigation or navigation would have to be curtailed sharply.

The Big Missouri is a big river with lots of water. But it isn't big enough; no river in the West ever has been or ever will be. Claims for water invariably exceed the supply. Sometimes the conflicting claims have been settled in the courts. More than once they have been "settled" with a Winchester rifle. In recent years the Interstate Compact has provided a rational and useful means of dividing up the waters, as we have just seen. But something more is needed. The Interstate Compact is inflexible and cumbersome. Also, whenever a major stream is involved, the federal government is not a perfect instrument for the expression of the will of the people. The administrative branch is unwieldly and too highly centralized, and its own lack of co-ordination makes possible such rivalries as that of the Army Engineers and the Bureau of Reclamation. On the policy-making side the pressure groups exert too much influence. Contractors, public utilities, and railroads are interested in the building of dams, navigable channels, and hydroelectric generating plants. They are not much interested in the people of the Missouri Valley.

Since the Pick-Sloan Plan was announced still other attempts to co-ordinate the views of these two rival bureaucracies have failed to secure the integration of soil conservation, wild life preservation, forest development, hydroelectric power, and industrialization with the reclamation and flood control aspects of the Pick-Sloan Plan. Recognizing the validity of the constant criticisms of the Pick-Sloan Plan by advocates of an MVA, General Pick set up the Missouri Basin Inter-agency Committee as a co-ordinating mechanism, adding to his own Engineers and the Bureau of Reclamation representatives of the Department of Agriculture, Department of the Interior, Federal Power Commission, and the Governors of the Basin states. The advice of the Committee 
has gone unheeded, however. At at meeting of the Committee in July 1948 Commissioner of Reclamation Warne found it necessary to issue a public statement pleading for the integration of the valley program, and in 1949 the Hoover Commission concluded that the inter-agency committees "have failed to solve any important aspects of the problem." 12

It is for these reasons, then, that scores of informed and disinterested observers and thousands of plain people in the Missouri Valley have come to the conclusion that a regionwide public authority, indigeneous to the valley, is by far the most hopeful method of administration yet devised for the formidable task of securing the over-all, integrated development of the resources of a great region.

When such an authority is achieved the struggle for water will not be abated. But it no longer will be a struggle to take water away from the other fellow. Instead, it will be a struggle to hold the water on the soil, checking erosion, and building up the water-table. It will be a struggle to arrest floods and prevent destruction of life and property. It will be a dramatic phase of the larger struggle of man against nature -an effort to use and conserve nature's resources with in. telligence and foresight. This is a concept to which men can give their loyalty and enthusiastic support. Agitation for a Missouri Valley Authority is strong and growing stronger. Here is the place where one might reasonably expect to find a rebirth of the Western liberal spirit.

\section{Freight Rates in Politics}

The threat of outside rivalry and the realization of shortcomings at home have done much to encourage a re-

12 Commission on Organization of the Executive Branch of the Government: Reorganization of the Department of the Interior (Washington, D. C., United States Government Printing Office, 1949), p. 29. 
gional spirit in the Mountain West. It is, nevertheless, a very recent manifestation. Only a few years ago the aggressive Southern Governors' Conference attempted to create an alliance between the South and the West based on the obvious similiarity of the economic interests of the two regions. Their attempt was a failure.

In September 1943 a group of Southern and Western governors met in Denver, at the instigation of the Southerners, in order to discuss their common interests. The Southerners stressed the freight-rate issue, but the Western governors were cool. ${ }^{13}$ Governor Vivian of Colorado even went so far as to sabotage the meeting. Taking advantage of his position as host to the conference, he introduced an unscheduled, uninvited speaker who "happened to be in Denver." The speaker was President William Jeffers of the Union Pacific Railroad, and his impromtu remarks turned into nearly an hour of cogent argument against interfering with the freight rate structure. The Western governors apparently were impressed, for in the end the attempt at an alliance of the South and West failed. The Western governors were not sensitive to the regional interests of the West, nor did they feel any sympathy for the similar problems of the South.

By 1948, however, the atmosphere in the West had undergone a significant change. Although a regional alliance with the South was not yet in sight, within the Mountain West a new attitude toward freight rates as a regional issue had begun to emerge. In 1943 the political leaders of the West were cowed by the pressure groups, and the railroad lobby had the situation well in hand. But by 1948 the Governor of Colorado, W. Lee Knous, could write to the governors of five other states in the region urging participation in

${ }^{13}$ H. C. Nixon: "The Southern Governors' Conference As A Pressure Group," Journal of Politics, 6:338-45, August, 1944 . 
a "war" on discriminatory freight rates. The "war" was declared by the Rocky Mountain Wool Council, a quasi-public body composed of representatives of the wool industry and representatives of state governments and dedicated to the encouragement and development of the Western wool industry on a regional basis. This council was organized in 1947 under the leadership of Governor Knous with the full cooperation of the other Western governors. Its creation demonstrated a new willingness of Western political leaders to find common ground for action.

In his letter the Governor recommended that the states intervene for the wool industry in hearings on rates before the Interstate Commerce Commission. He also expressed a sound, regional point of view rather than a narrow sectionalism when he said:

"As governors I think we should be interested in two general proposals: first, that we foster and encourage development of a healthy wool production industry, and second, that we encourage the sound development of wool processing in the Rocky Mountain region." 14

In October 1949 the Interstate Commerce Commission issued a ruling directing the railroads to reduce wool and mohair freight rates on a sliding scale based on carload minimum weights. From the point of view of Western development, the ruling is not a happy one. The reduction is not substantial. Worse still, the differential between raw wool and processed wool is made even more favorable to the shipment to the East of raw wool. The traditional advantage for the movement out of the West of raw materials instead of finished products has not been disturbed.

The failure of the Council to achieve a satisfactory revision is disappointing. Nevertheless the attitude expressed by the Governor and reflected in the activities of the Rocky 14 The Denver Post, July 16, 1948. 
Mountain Wool Council gives evidence of a new regional outlook in the Mountain West greatly different from the attitude shown during the Conference of the Southern and Western governors in 1943. It is certain that if the Southern governors were to try again they would no longer receive such a cold reception.

\section{The Rise of Regionalism in the Mountain West}

The evidence of a new regionalism in the Mountain West just described is impressive but not conclusive. Any region might be expected at any time to close its ranks against an outsider as the states of the Upper Colorado Basin did at Vernal. The attempt to sustain the declining wool industry might also be a transient gesture. The real question is whether the recent manifestations of a regional outlook in the West rest upon the permanent foundation of a deep conviction rather than upon the needs of the moment.

Fortunately for the Mountain West, there is reason to believe that a permanent foundation for a regional movement is being built today in every state in the Rockies. Of course regionalism in the West is still in its infancy, and it does not yet possess the sweep and vigor of the regional movement in the South. Nevertheless, the pattern is emerging and taking a form very similar to Southern regionalism. It is a pattern in which three major trends are apparent: the emergence of a regional point of view in politics, the growth of a regional literature, and a stirring of regional thought and action in the universities of the area.

Perhaps enough already has been said about political action in the preceding chapters. In the political sphere sectionalism is likely to precede regionalism, and some of the political activity in the Mountain West today is sectional in 
character. Nevertheless, the point of view of such men as Governor Lee Knous of Colorado and Senator Joseph O'Mahoney of Wyoming is not narrowly sectional. Other political leaders in the West also have advocated regional development within the framework of an integrated national economy. Two brief quotations, one from Senator Dennis Chavez of New Mexico and the other from Senator Lester C. Hunt of Wyoming, illustrate the point. Both of these quotations are taken from "Guest Editorials" in the Denver Post, itself a potent force for regionalism under the leadership of its new Editor and Publisher, Palmer Hoyt.

Senator Chavez has expressed the emergent idea of Western regionalism in these words:

"We need in the west leadership of the type of Governor Arnall of Georgia. The organization of the southern states under his vigorous sponsorship and their concerted fight on the unfairness and inequity of the freight rates should make us ashamed that we in the west, who are penalized just as unfairly, have not provided leadership and organization to undertake a similar fight in our own behalf.

"Public lands should be returned to the states, our immense natural resources should be developed and utilized by industries located within our own borders and close to these sources of supply. Products produced by these industries much reach the markets in other parts of the country without the penalizing burden of unjust freight rates."

Senator Hunt also is concerned with industrialization and with a balanced regionalism:

"The west, with 21 per cent of the population, has been content with only 11 per cent of industry. Manufacturing has become so concentrated in a few states in the east that an area comprising approximately 10 per cent of the United States boasts of over 70 per cent of the manufacturing of the entire country. Why this concentration? Could it be because eastern lobbies are closer to Washington and/or the ancient 
freight rate structure dividing the country into regions making region 1 , the northeastern states, the favored region? . . .

"This nation of ours will grow greater and greater, but to adequately fulfill its destiny, all sections must be developed. None can be neglected. There is no limit to our realization of tomorrow if we, the Rocky Mountain Empire States, work together, all for one and one for all, to bring and retain that development to which the west is justly entitled." 15

Ten years ago it would have been impossible to find more than an occasional isolated statement of opinion such as these. Today Senator Chavez and Senator Hunt are expressing a typical and common point of view.

In the field of literature a new type of book about the West is being added to the long shelf of Western fiction, biography, and travel which has been accumulating for many years. This is the type of book which deals, with current economic and social problems in the West. At least four such books have appeared in the last few years. Among them Joseph Kinsey Howard's superb Montana High, Wide, and Handsome has been most widely read and commented upon. Economic Freedom for the West by Wendell Berge states the need for Western industrialization and examines the barriers preventing its achievement with great force and clarity. A. G. Mezerik in Revolt of the South and West describes the major problems of the two regions and reports the growing unrest which is developing among Westerners. Ladd Haystead's If the Prospect Pleases-the West the Guidebooks Never Mention also reflects clearly the love of the Westerner for his region and his growing awareness of its economic problems.

Books of this type perform an important function in the West. They crystallize the nascent regional spirit and give it

${ }^{15}$ Both quotations also appeared in an article by Morris E. Garnsey: "The Rise of Regionalism in the Mountain States," The Nation, special Western supplement, September 21, 1946, p. 19. 
a firm theoretical and ideological basis. Even Butte, the dying city, roundly criticized by Howard and by John Gunther in Inside U.S. A., recently has shown signs of the rise of a civic spirit which promises to give it new life and vigor. ${ }^{16}$ Butte's program has the support of the Anaconda Copper Company which is contributing substantially to the city's plans for hospitals and recreation facilities. The new activity in Butte is a highly significant example of a general growth of interest in regional problems throughout the Mountain West. It also illustrates the importance of a regional literature in the growth of a regional movement; since there is plenty of evidence that Butte has not been insensitive to such frequent criticisms by first-rate writers and journalists.

The universities of the region are a third factor in the creation of a regional spirit in the Mountain West. At the state universities of Colorado, Wyoming, Utah, New Mexico, and Montana substantial programs of research in regional problems are getting under way. Private institutions, such as the University of Denver, also have initiated regional programs, while the state colleges of agriculture and mining have been doing specialized research on regional resources for many years.

Probably the most advanced of these research programs is the "Montana Study" which is being carried on at the University of Montana under a grant from the Rockefeller Foundation. The purpose of the Montana Study is "to enrich the quality of living in the State of Montana." To achieve this purpose it has developed a program for bringing the intellectual stimulus of the university directly to the people of the state in their respective communities. The movement has led to extensive self-analysis by the typical Montana community, and self-analysis has led in most cases

16 Joseph K. Howard: "What Happened in Butte," Harper's Magazine, 197:89-96, August, 1948 . 
to programs of self-improvement. In several towns the economic base of the community has been analyzed. The cultural and social resources of the community have been assessed; and as a result there has been an awakened interest in schools, libraries, drama societies, and other forms of community life. In short, Montana is building an economic base and an indigenous culture capable of competing successfully with the more glittering attractions of the urban society beyond the borders of the state.

Programs such as these are a distinct asset to the region and an encouraging sign of the emergence of a regional spirit in the West. As yet none of them has achieved the stature of the regional activities of the University of North Carolina. Nor does the Mountain West possess today a Committee for the West, parallel to the Committee for the South, which would co-ordinate the scattered efforts of the various research agencies and produce a comprehensive regional program comparable to the program of research and education which is now operating in the South. Nevertheless, a beginning has been made, and the future of regionalism in the Mountain West looks promising. 



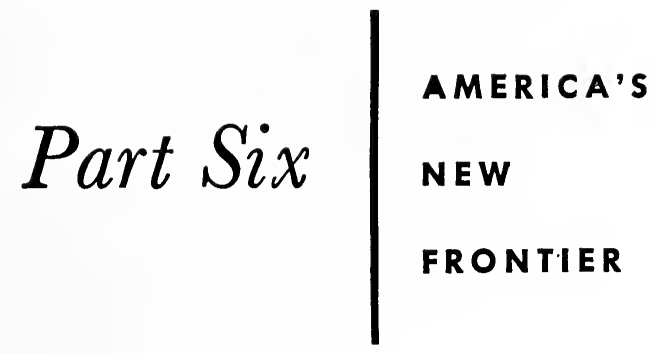





\section{Chapter 10. The West-A New Frontier}

The Mountain West is our last frontier. As the postwar boom draws to a close the Mountain West remains a relatively undeveloped region. Population, income, investment, and opportunities for employment in the Mountain West have not kept pace with the national growth since 1940; and in all of these categories the region has lagged far behind the growth on the Pacific Coast and in the Southwest. Originally passed over by the first wave of the westward movement in the $1850^{\circ}$ 's, and only tardily developed a little more than a half-century ago, the Mountain West is again being skipped over in the present phase of the westward migration of the American people.

The years ahead are crucial years for the Mountain West. If its development continues to lag and if its essential and limiting supplies of scarce water are drained off to California and Missouri, the last chance for major expansion of the area will disappear. If, on the other hand, the region embarks upon a determined program of development, its great resources will yield a tremendous outpouring of wealth and 
income. The addition of five or six million acres of irrigated land to the nation's harvested cropland, the production of millions of barrels of oil from shale and coal, the extraction and manufacture of tons of phosphate fertilizer and other minerals, and the installation of 12 million kilowatts of hydroelectric generating capacity would appreciably augment the nation's productive power and increase the national income. Under such a program the Mountain West would again become a frontier-a new frontier in American life.

A program of this magnitude would involve a tremendous expansion in the previous volume of investment in the Mountain States. The reclamation and power features of the program would require the expenditure of from 5 to 6 billion dollars (1944 prices). Spread over 20 years, this would mean an average annual expenditure of from $25^{\circ}$ to 300 millions. Some idea of the task required to utilize the irrigation and power potential of the region is gained when it is realized that the Bureau of Reclamation has invested only about one billion dollars in the reclamation works in 17 states during the 45 years of its existence. The Bureau's past expenditures for construction in the eight Mountain States has varied between 25 and 75 millions per year; so the future program would require the expansion of the present program by 300 to 400 per cent.

If we add to reclamation and power development a program of the same order dealing with soil conservation and maintenance and improvement of forests and range lands, another 100 millions per year of investment expenditure would be required. The development of oil-shale and phosphate production in the Mountain West would involve an investment of 1.5 to 2 billions. The Atomic Energy Commission has announced plans to invest a half-billion dollars in the region within ten years. Thus, the total investment expenditure in major conservation and developmental works in the 
Mountain West approximates $4^{00}$ to $5^{00}$ million dollars per year for the next 20 years.

It is difficult to assess the precise significance of a Western investment of this size. Up to now economists and statisticians have made little attempt to analyze investment on a regional basis. Hardly any published data on investment by states or regions exist. Consequently, it is almost impossible to make a satisfactory estimate of the effects of a 400 million dollar annual investment on the regional economy of the Mountain West or on the national economy. Nevertheless, it seems obvious that such an investment in conservation and development each year would stimulate a regional growth of population and of industry which would require a large volume of private industrial and consumer investment. A very rough guess is that the investment of public funds in conservation and development in the Mountain West will on the average amount to about 20 per cent of total investment in the region. On this basis, total investment would be 2 billions per year when 400 million dollars were being spent on resources development projects. The impact of an annual investment of 2 billion in the region would be very great. Investment in the eight states in 1947 probably amounted to somewhere between 1 and $11 / 4$ billion dollars. In 1944, investment in the region may have reached 700 million dollars. It is this figure which should be compared with the 2 billions, because the latter is expressed in 1944 dollars.

While a three-fold increase in total investment in the Mountain West would have a very strong effect on the region, the effect on the national economy of such an investment in the frontier West during the 5o's and 6o's will depend chiefly upon the level of investment in the economy as a whole. If total national investment should slump as the result of a cyclical down-swing, a sustained Western program would loom larger in importance. With full employment, the 
effect of the Western program might not be strongly felt outside the region itself. The Twentieth Century Fund study estimates that, with full employment, total investment in capital goods of all kinds in 1960 would be 33 billion dollars. Of this total, the Western states might be expected to contribute 3 or 4 per cent ( $\$ 1$ to $\$ 1.32$ billion) without any program of expansion at all. Thus, a two-billion-dollar investment in the West would increase the national total investment by only about 2 or 2.5 per cent. ${ }^{1}$

Nevertheless, a Western investment of this magnitude could have important effects upon the national economy. If the program were properly planned, the annual rate of ex-

1 The preceding estimates necessarily are very rough. The estimate of reclamation and power expenditures was secured by applying an average construction cost per acre and per installed kilowatt in $194^{8}$ to the resource figures cited earlier. This result was then deflated to the 1944 price level by the Engineering Record's index of construction costs. The estimates of annual expenditures for soil conservation, forest and range land improvement were based on a regional allocation of the Dewhurst estimate of needs for expenditures in these categories (Dewhurst, op. cit., Table 149, p. 455). The estimate of cost of oil-shale and phosphate mining developments was based on current costs of construction of mining and oil refining enterprises deflated to the 1944 price level. The estimates of the relation of total regional investment to total national investment and the relation of regional conservation and development investment to total regional investment were secured by applying the relationships among these variables revealed in Dewhurst's America's Needs and Resources, Table 135, p. 386 and Table 136, p. 388 , to regional data on construction investment recently made available in the Commerce Department's statistical supplement, State Distribution of Construction Activity, 1939-1947. (United States Department of Commerce, Bureau of Foreign and Domestic Commerce, Construction and Construction Materials: State Distribution of Construction Activity, 1939-1947. Industry Report: Statistical Supplement. Washington, D. C., June 1948.) For example, expenditure on conservation and development works in the United States has been roughly 3 per cent of total investment expenditure. At the same time, approximately 20 per cent of national investment in conservation and development has been made in the Mountain West. Thus, the proportion of conservation and development investment in the region to total regional investment is greater than in the nation at large. Hence, the estimate is reached that 20 per cent of all regional investment is in conservation and development works. In estimating total regional investment it was assumed that the ratio of construction investment to all investment was approximately the same in the region as in the nation, particularly if the secular relationship is considered instead of the annual relationship. The latter, of course, is strongly affected by cyclical variations in construction activity. It is to be hoped that eventually data on investment and gross national product by states and regions will be made available. 
penditure could be adjusted to compensate for cyclical fluctuations in the national economy. In this case the multiplier effect of Western investment on the total economy would be greater than a similar investment distributed over time without reference to the cycle. In addition, planned investment would have the qualitative effect on the national economy of damping down cyclical fluctuations and giving the economy a greater degree of stability.

The preceding figures have been based mainly upon the concept of the maximum utilization of the physical resources of the Mountain West. Both the magnitude and timing of the program might be modified when comprehensive studies of the costs and benefits of each particular project can be made. Nevertheless, a good case can be made for thinking in terms of the maximum utilization of physical resources. A growing population, a secular rise in the standard level of living, and an economic philosophy based on maximization of human welfare all point to the ultimate full utilization of the physical resources of the Mountain West.

One thing is certain. The adoption and execution of such a program would hardly be possible without a revival of the frontier spirit in the West. As we have seen, the opening up of the Mountain West after 1860 was greatly facilitated by the railroads. Aided by generous government grants, the railroads followed the policy of "building ahead of the traffic." By so doing they hoped to create traffic, and in this they were successful. Colonization and settlement followed the new lines, and the volume of freight and passengers rose rapidly. But, far more important, the building of the railroads stimulated the creation of additional wealth and income in the West and elsewhere many times greater than the returns to the railroads. These railroad pioneers understood that in the long run supply creates its own demand and wealth multiplies upon wealth. 
The Mountain West of today needs to recapture the venturesome spirit of an earlier day and overcome the timidity of government bureaus and the opposition of pressure groups in order to build its dams and power plants ahead of the present "traffic." For hydroelectric power and irrigation are even more productive than railroads, and provide a greater stimulus to other types of economic activity.

The policy of building in anticipation of demand almost always has justified itself in the United States. Most recently, the prosecution of World War II was greatly aided by the use of the then tremendous power reserves built by the federal government during the 3o's at Bonneville, Grand Coulee, and at Norris Dam. Only Oak Ridge, Tennessee, and Hanford, Washington, could find the power for the atomic bomb project. And now that peace has come, the pre-war power reserve has turned into a nation-wide power shortage.

There is reason, therefore, to think in terms of the full utilization of our available resources. An increasing population and a rising level of living will require the extension of irrigation to the uncultivated lands of the West, while the ever-growing demand for electricity and minerals in a society based on the use of mechanical power calls for the expansion of Western hydroelectric power and the wider exploitation of Western minerals. The West awaits the implementation of a regional and national program for the full utilization of its resources. It stands ready to become, once again, the dynamic American frontier.

\section{The Conservation Frontier}

It is easy enough to see how the West may once more become an economic frontier in the years ahead. The physical resources are there, and they are certain to be used. But why should the West become a new frontier in the conservation 
movement? What claims does it have to a special interest or activity in the generalized problem of the conservation of natural resources?

There are a number of direct answers to these questions. First of all, there is the simple and obvious logic of the proposition that the relative maturity of the American economy and the conditions of modern technology make resources development and conservation the inseparable parts of a single program. It is no longer logically or practically possible to devise a large-scale resources development program without a corresponding plan for the conservation of those same resources.

An American frontier in the twentieth century will be quite a different thing from the frontier of the last century. When the Civil War ended and the westward movement resumed in volume, the Mountain West was virgin territory. Its population of less than two hundred thousand was concentrated in a few trade and mining centers. Only the Mormon settlements of Utah bore any resemblance to an established society. Today the economy of the region is highly developed. Four and a half million people inhabit it in numerous cities and towns which are knit together by paved highways, railroads, and airlines. The major resources of the region have been surveyed and mapped. The better land has passed into private ownership and the forests set aside as national reserves. Enormous untapped resources still exist, but the cream has been skimmed off. The day of easy, individual exploitation is gone. Present-day development will require large amounts of capital and labor and the co-operation of many individuals and many agencies of government. Such development must be based on a large-scale, comprehensive, and well-integrated program of multiple-purpose projects. This is the only way to make the best possible use of our remaining limited resources. 
It is highly significant that the concept of integrated, multiple-purpose development actually emerged from the conservation movement. The idea of a unified approach to problems of resources utilization, which is now so familiar, has come into prominence in recent years, more or less coincident with the development of the Tennessee Valley Authority. But forty years ago the same idea was expressed as the genesis of the conservation movement. In his autobiography, Gifford Pinchot tells dramatically of the crystallization of the concept of a unified attack on the problems of resources conservation and development.

"A man by the name of Pinchot," he writes, "was riding a horse by the name of Jim on the Ridge Road in Rock Creek Park near Washington. And while he rode, he thought. He was a forester, and he was taking his problems with him, on that winter's day of 1907 , when he meant to leave them behind.

"The forest and its relation to streams and inland navigation, to water power and flood control; to the soil and its erosion; to coal and oil and other minerals; to fish and game; and many another possible use or waste of natural resources -these questions would not let him be. What had all these to do with Forestry? And what had Forestry to do with them?

"Here were no isolated and separate problems. My work had brought me into touch with all of them. But what was the basic link between them?

"Suddenly the idea flashed through my head that there was a unity in this complication-that the relation of one resource to another was not the end of the story. Here were no longer a lot of different, independent, and often antagonistic questions, each on its own separate little island, as we had been in the habit of thinking. In place of them, here was one single question with many parts. Seen in this new light, all these separate questions fitted into and made up the one 
great central problem of the use of the earth for the good of men ...

"To me it was a good deal like coming out of a dark tunnel. I had been seeing one spot of light ahead. Here, all of a sudden, was a whole landscape. Or it was like lifting the curtain on a great new stage...

"E Pluribus Unum is the fundamental fact in our political affairs. E Pluribus $U n u m$ is and always must be the basis of dealing with the natural resources. Many problems fuse into one great policy, just as many states fuse into one great Union. When the use of all the natural resources for the general good is seen to be a common policy with a common purpose, the chance for the wise use of each of them becomes infinitely greater than it had ever been before . . .

"Today, when it would be hard to find an intelligent man in the United States who hasn't at least some conception of what Conservation means, it seems incredible that the very word, in the sense in which we use it now, was unknown less than forty years ago." 2

The conservation movement grew with great rapidity. President Theodore Roosevelt made it the keynote of his administration. The forty-eight governors endorsed its philosophy in a conference in Washington in 1908. From that time on, the frontier philosophy of exploitation of resources lost ground, and the idea of utilization through conservation gained strength.

The new movement had a very strong impact on the Mountain West. For in 1907 the great remaining areas of public domain which could be set aside for posterity and the national interest were here in the West. And it was in the new national forests that the practice of conservation on a large scale began. In the single year of 1907 , some 57 national

${ }^{2}$ From Breaking New Ground by Gifford Pinchot, copyright, 1947, by Harcourt, Brace and Company, Inc. 
forests and forest reserves were created. During the whole of the Roosevelt administration $15^{1}$ forests and reserves were set up in the United States and its territories. Of these an even hundred were located in the Mountain West. The newly established forest areas encompassed nearly 53 million acres. Previously, under Harrison, Cleveland, and McKinley, some 23 million acres of forest in the Mountain West had been reserved for national use, so that by 1909 there were 76 million acres of national forest land in the eight states of the Mountain region. Conservation became visible and tangible to nearly every citizen of the West, and the advantages of conservation soon became apparent on every side. Thus, in a relatively early period, conservation became an accepted institution in the Mountain West, and the groundwork was laid for the wide diffusion of both the idea and the practice.

For, as it has turned out, the people of the West have not been content to regard conservation as an alien practice found only in the national parks and forests owned by the federal government. In recent years they have shown a steadily increasing, and in some cases pioneering, interest in conservation projects which they themselves have initiated and developed. This is a third reason for believing that the Mountain West is now, and will continue to be, a leader in the Conservation movement.

In Montana in the decade of the 2o's the severe depression in agriculture provided the stimulus which induced various groups of farmess and ranchers in the state to undertake a comprehensive examination of their problems and their plight. Out of their efforts there arose three notable, independently conceived plans for dealing with the fundamental causes of agricultural distress. All these plans have a strong conservation aspect." The Teton County "unified county

3 Howard: Montana High, Wide, and Handsome, op. cit., Ch. 26. 
program," which originated in 1922, embraces soil conservation, water utilization, erosion control, weed and pest control, range management, tax revision, and even health and recreation. The Mizpah-Pumpkin Creek Co-operative grazing district was set up in 1928. Under it the resident and adjacent ranchers voluntarily limited the number of cattle which they could graze on the 108,00o acres of the area. They also built stock-water reservoirs, eradicated pests, and applied other conservation measures.

The plan was a success from the start. On this controlled range cattle grazed in the drought years of the 3o's while in other areas, where overgrazing existed, the grass disappeared under the hoofs of the hungry herds. The Mizpah-Pumpkin Creek experiment became the basis for the Taylor Grazing Act of 1934, one of the more recent milestones in the federal government's program of conservation. The third Montana experiment was the "Malta plan" for farm resettlement which was launched in 1930 by a group of farmers and businessmen in the Milk River Valley. Later the Malta plan was adopted by the federal government, and it became the first farm resettlement program sponsored by the New Deal as a part of its recovery policies. The planning, inspiration, and control of resettlement in Montana were the work of Montanans. The plan was indigenous and democratic and not imposed from outside.

The Teton County, Mizpah-Pumpkin Creek, and Milk River Valley projects are examples of a pioneering interest in conservation and resources utilization. In them the people of the locality have taken the lead in planning for and initiating the program, in securing co-operation of the various individuals affected, and in working out a basis of agreement and co-operation with the federal government.

Another instance of the pioneering development of con- 
servation practice in the West is found in the experiences of the Dust Bowl.4 The great storm of May 12, 1934, carried away millions of tons of topsoil and deposited much of it in the streets of New York and Philadelphia. This spectacular event dramatized the incredible destructiveness of wind erosion on the light soils of the semi-arid plains and led to the acceleration of a many-sided attack on the soil-blowing which had destroyed the fertility of hundreds of thousands of acres of farm lands in the Western Great Plains. At its maximum the Dust Bowl covered an area 500 miles long and 250 miles wide in western Kansas, eastern Colorado and New Mexico, and in the panhandles of Oklahoma and Texas. At times more than eight million acres of land were "blowing," while "blowing hazards" existed on over $5^{\circ}$ million acres. But by 1938 conditions had improved greatly. Six or seven million acres of land were being cultivated on the contour in strip crops, and the practice of summer fallowing had become widespread. Over 12 million acres of grazing land had been retired temporarily, or otherwise made subject to conservation practices. The federal government had restored the grass on other millions of acres of plowed land and sand dunes. By 1940 hardly a farmhouse in the region was without its shelterbelt of sturdy trees. Conservation was succeeding in the long fight to stabilize the agriculture of the Dust Bowl.

But if the Battle of the Dust Bowl had been nearly won by 1940 , the Conservation war itself was by no means over. For after 1940, World War II's destruction of much of European agriculture and the inflation in the United States induced the farmers of the Great Plains to plow up and plant to wheat millions of acres on which conservation had just been introduced for the first time. The greatest sinners in this respect were the absentee owners and "suitcase farmers."

4 These experiences are ably recounted by Vance Johnson: Heaven's Tableland (New York, Farrar, Straus and Company, 1947). 
These men ripped up vast acreages of grassland with no thought beyond the current crop. By contrast, the settled farmers, while joining the boom, tried to practice conservation in their expanded operations. When a farmer has had to lease and work 2,500 acres of adjoining land to protect his own 1,750 acres from blowing, he is not soon going to forget conservation-even with wheat selling at $\$ 2.50$ a bushel.

The recent history of the Dust Bowl provides an excellent illustration of the frontier character of conservation in the West. The Western conservationist is in the front line of the battle against the destructiveness of nature. He must constantly devise new techniques and methods of conservation. And as these techniques become more efficient, they demand more skill and more ability on the part of the individual farmer and greater unification of effort and co-operation among individuals over constantly widening areas. In Colorado, for example, the working out of a conservation program for the typical irrigated farm involves the selection of the appropriate combination of as many as fifteen or twenty different soil conservation practices. The technical analysis of the problems of conservation on such a farm requires the expenditure of two or three times as many man-hours as farms in the Middle West where no more than four or five different practices need be considered. ${ }^{5}$

Equally important, the Western conservationist must also battle against the destructiveness of man. A significant minority of absentee owners, "suitcase farmers," and land grabbers remain. These men are indifferent or antagonistic to conservation. It is they who attack the Forest Service and demand the return of public lands to private exploitation. It is they who plow up the grasslands and fight against an MVA. It is because of them that the West must continue to be a

5 I am indebted to Kenneth W. Chalmers, State Director of Soil Conservation, for an enlightening discussion of the Western conservation problem. 
frontier in the progress of the conservation movement. For nowhere do selfish aims appear in their true light more clearly than against the physical environment of the West. Better than any other region of the United States, the topography and climate of the West dramatize the essential unity of all aspects of resources use and conservation and the necessity of man's adaptation to Nature. Also the semi-arid West demonstrates most vividly the rewards which are to be gained from the prudent use of our national heritage. On the Western Plains one may see, side by side, the heavy golden wheat of the summer-fallowed, contoured field and the drooping stalks of blighted grain where conservation was neglected. Here, also, in the irrigated valleys one may see the vivid actuality of the biblical prophecy that "the desert shall rejoice and blossom as the rose." There can be little doubt that the American West is destined to be one of the important frontiers in the twentieth-century revival of the Conservation movement. 


\section{Chapter 19. The New Frontier of American Liberalism}

As we approach the second half of the twentieth century the people of the Mountain West are faced with the great issue of the determination of the locus of power in society. The problem is to decide how great a centralization of power is compatible with human liberty and economic progress. Of course, this is by no means simply a regional problem. It is found everywhere today-in the uneasy sphere of international relations and in the search for an answer to such vital questions as how best to control atomic energy and utilize it for peaceful ends. Nevertheless, within the United States there is no region in which this universal problem of the concentration of political and economic control is focused more sharply than in the Mountain West. In common with the rest of the country, the West has seen the growth of the concentration of economic power in our corporate economy; but unlike other regions it has felt keenly the effects of the exploitation and neglect incident to that concentration. The West has not liked what it has experienced. Frequently in the past the Western states have protested against the concentration of economic power in Eastern corporate agglom- 
erations and have appealed to the federal government to protect the region from exploitation.

Now the West is faced with a new phase of the generalized issue of who is to control its future. On the one hand, it is slowly coming to the conclusion that government must play a major part in the future development of its resources. We have seen why this is so. In the West the conditioning factors of the physical environment, the nature of the natural resources, the effects of technology, and the need for conservation demand large-scale, integrated, multiple-purpose resoure development projects. Such projects are beyond the scope of private enterprise. The initial capital cost is too large and the rate of return per year too low to be attractive. More important, such projects require large expenditures for social purposes-flood control, public health, and wildlife protection. Such expenditures for indirect social benefits are properly incurred by government, but they cannot be assumed by the individual enterpriser who has no way of recovering his outlay.

On the other hand, while the Mountain West dislikes Big Business, it also distrusts "big government." The reasons for this attitude are obvious. Antagonism to government and a belief in laissez-faire are ingrained in our cultural tradition. In addition, certain forces in Western society-corporate interests, pressure groups, and the ultra-conservatives in business and politics - have elevated the laissez-faire tradition to the status of dogma in many Western minds. It is true that these attitudes are not peculiar to the West, but the West was recently a frontier society; and the belief in these ideas is held with a tenacity and defended with a violence not often found in the older, urbanized sections of the United States.

Thus the issue is joined. The conservatives cling to an outworn tradition, abetted by the vested interests who defend the status quo as a measure of self-defense. In opposition, the 
liberal point of view holds that economic expansion and conservation are imperative; and looking forward to this end the liberal is willing to call on government to take the lead in creating long-range projects of tremendous scope and imagination.

This does not mean that Western liberalism in the United States has become a perverted authoritarianism disguised by an honorable name. On the contrary, the chief preoccupation of the liberal advocate of resources development in the West is with the preservation and enlargement of human liberty. This is why the liberal wants economic development-for without a wider economic base and a more stable economy, Western farmers and workers frequently will find themselves deprived of economic freedom to work and produce, and denied that Freedom from Want which has been added to our Bill of Rights. ${ }^{1}$

Nor does Western liberal opinion overlook the dangers of the concentration of power when it advocates the expansion of the functions of government. For liberal opinion in the West holds that there are ways to resolve the issue of the concentration of economic and political power in modern society. The Western liberal wants the West to take those ways, adapt them to western conditions, and improve them for greater usefulness. Should the West do so it would succeed in creating a new frontier of liberal thought and action in the United States.

There are at least three important ways in which the people of the West can act to maintain control over their own destiny while entrusting government with a larger role in economic development. They can strengthen their state governments, set up regional authorities in the major river

1 See “A New Bill of Rights" in National Resources Planning Board, National Resources Development Report for 1943. Part 1. Post-War Plan and Program (Washington, D. C., United States Government Printing Office, 1942), p. 3. 
basins, and they can make use of nongovernmental associations of many types. On the whole the Western states are poorly governed-although perhaps no more so than states in other regions. In the West state governments are outmoded, cumbersome, and creaking at the joints. The states need new constitutions, the streamlining of administrative procedures, and better administrative personnel. The caliber of the state legislatures is not high, and the special-interest groups and lobbies exert far too much influence. As a result of these factors the states are not doing a good job of resources development. Here and there a Fish and Game Commission or a Water Board may be functioning effectively, but the over-all integrated approach is entirely lacking. Yet there is much that the state could do in this sphere if it were efficiently organized. Some types of resources, such as the metals, coal, and oil, could be developed effectively at the state level. Also, there are significant possibilities in interstate co-operation, as we have seen in our discussion of the Colorado River Compact (Chapter 18).

Nevertheless, it is doubtful if state governments could prove adequate to the task of Western development no matter how efficient they might become. From the point of view of the resources pattern of the West, the state is an artificial entity, heterogeneous within itself, and too small to deal with regional problems. Nor is the state an effective repository of power. State governments are too restricted in jurisdiction to be strong enough to deal with national corporations and nation-wide pressure groups. Westerners will hope to strengthen and improve state government, but they will not allow themselves to expect too much from it.

The real hope for effective development of Western resources lies in the adoption of the administrative device of the regional authority. Throughout the pages of this book evidence has been presented which shows that the regional 
authority is particularly adapted to deal with the conditions of the Western problem. In addition, the almost unanimous judgment of literally hundreds of experts is that the regional authority, as exemplified in the Tennessee Valley Authority, has proved to be an outstanding success in dealing with the problems of multiple-purpose resources development. ${ }^{2}$

The success of the TVA is due to many factors, but to the Western liberal its great success lies in the fact that it has done its job without encroaching upon the freedom of the individual. The regional authority has achieved a decentralization and diffusion of power which is particularly attractive to the Westerner. The West is too far away from Washington and too different in its physical characteristics from other regions to be governed from the banks of the Potomac. To the Westerner regional decentralization looks like the answer to his particular version of the problem of the concentration of power in our society.

This conclusion is reinforced by the fact that the regional authority actually encourages the development of the third type of organization which the Westerner can use to preserve his essential liberties. This is the use of voluntary nongovernmental associations of all kinds as a means for the democratic expression of opinion concerning government policy. Labor unions, chambers of commerce, women's clubs, sports and recreation associations, farm clubs, and parentteachers associations can provide a mechanism by which people can express their opinions and make their desires felt by governmental agencies. The TVA has made effective use of

2 Myres S. McDougal: "Foreword-Regional Planning and Development: The Process of Using Intelligence, under Conditions of Resource and Institutional Interdependence, for Securing Community Values," Iowa Law Review, 32:193-202, January, 1947; and Asa D. Sokolow: "Governmental Techniques for the Conservation and Utilization of Water Resources: An Analysis and Proposal" in The Case for Regional Planning with Special Reference to New England (Myres S. McDougal and others; New Haven, Conn., Yale University Press, 1947), pp. 80-94. 
such organizations in creating a regional spirit behind its regional program. Already there are examples in the West of the function of voluntary organizations of various kinds in preserving a balance among opposing forces in society. To mention only one, the Izaak Walton League has been one of the strongest forces in counteracting the attempts of other private organizations to get control of the public lands.

Western liberal opinion does not fear the threat of totalitarianism which the conservative professes to see in a vigorous resources development program. The misgivings of the conservative are specious and unfounded. The evidence of experience and logic demonstrates that adequate safeguards against the concentration of power exist in the checks and balances of a decentralized federal authority working in co-operation with state governments and scores of people's organizations of all kinds. Decentralization provides the form of administration most likely to maintain a constant responsibility to the people; and the continued association of the people with the government is calculated to maintain a vigilant public, determined to keep its agencies responsive to the common will.

\section{Western Liberalism and Social Action}

But what are the chances for the creation of regional authorities in the West within the next decade or so? Western liberal opinion is undoubtedly a minority opinion at the present time. Is there any reason to believe that the majority will come to accept the liberal view?

In previous chapters it has been pointed out that the issues and forces out of which a liberal movement could be built do exist in the West. Equally important, the pressure of regional and national demands for resources development 
will grow rather than diminish, and this fact will help to overcome the restrictive policies of the conservative. But most important of all, the Western liberal believes that the Western environment and the Western tradition will lead eventually to the creation of Western regional authorities for the large-scale development of the Mountain West.

The history of the West has been a history of the slow and painful, but ultimately successful, adaptation of Western society to the Western environment of rugged mountains and semi-arid plains. From the beginning, this process of adaptation has led the Westerner to create social forms appropriate to the situation. From the beginning, these social forms have been co-operative and collectivist.

Charles Howard Shinn, writing in 1884 , showed how the miners in the mining camps of the $5^{\circ}$ 's and 6o's built up an orderly society based on ad hoc "laws" which later became embodied in the legal codes of the territories and states. Shinn concluded that the fundamental contribution of the mining camps to Western society lay in arrangements that were devised for co-operation among the miners in establishing order, protecting property rights, and engineering cooperative methods for getting out the ore they had come to find. Such activities he believed had had a more permanent effect on American society than the spectacular aspects of the rugged individualism of the day. After describing various examples of social action, he observed:

“. . . Now, that (the co-operative spirit) in the last analysis, was and is the feeling fostered in true mining-camp life. In camps, too, we have something of the guild idea. The weavers and the goldsmiths of the Middle Ages had the fraternity feeling, and so have the miners of America. Sturdy self-reliance, mingled and tempered with a high appreciation of one's dependence upon others; the power to stand alonethe power to organize, if need be, with sudden energy and 
startling swiftness-these were traits fostered by the patient toil of the miners of America; and because of qualities such as these, the fame of the pioneers of California and the Rockies has gone wherever winds blow or waters run." 3

What was true of the mining camps was also true of the later agrarian society. In 1903, after twenty years of pioneering development in irrigated agriculture, Elwood Mead wrote:

"The lesson of these years is that the vital agricultural problem of the arid West is to establish just and stable titles to water and provide for their efficient protection in times of need. Every farmer in this region comes to understand the overshadowing importance of water. Their farms extend along many rivers for scores and even hundreds of miles. Every irrigator from a stream is bound to his fellow-irrigators by their common tie of dependence upon it. The amount diverted by one ditch is a matter of concern to all other ditches below, because it affects the volume remaining for their use. The independent life of the farmer in humid lands is impossible. Irrigated agriculture is an organized industry, and the prosperity and happiness of those engaged in it are largely determined by the character of its institutions." 4

3 Charles Howard Shinn: Mining Camps: A Study in American Frontier Government (New York, Alfred A. Knopf, 1948), pp. 275-6. Charles Howard Shinn was at Johns Hopkins University when he wrote Mining Camps in 1884. Subsequently he achieved a distinguished career as a writer, agronomist, and forester in California. He was one of Pinchot's most effective and able crusaders in California in the 189o's and after. His memory is honored by Mount Shinn, on the San Joaquin River in the Sierras.

${ }^{4}$ Elwood Mead: Irrigation Institutions (New York, The Macmillan Company, 1909), p. vi. In 1884 Elwood Mead was appointed to the first Professorship of Irrigation Engineering in the United States at the Colorado State College of Agriculture. Later he was the State Engineer of Wyoming and wrote the code of irrigation procedure which was adopted by Wyoming and by several other states and foreign countries. For many years he was Professor of Rural Institutions at the University of California, and served as Commissioner of Reclamation from 1924 to 1936 . Mead was devoted to the cause of reclamation and conservation and to the interests of those who live upon the land. Lake Mead, which lies behind Hoover Dam, was named in his honor. 
At that time the pressing problem was to develop a legal code under which men could best co-operate for the mutual use of a single water supply. The problem today is not the relatively simple one of enacting laws to share water, but of creating social institutions capable of seeing to it that water and other scarce resources are used most effectively. However, today's problem cannot seem more difficult to us than Mead's problem must have seemed to him forty years ago. For what the West had to do was to abandon the whole accumulation of water law originating in England and in the East, which was based upon riparian rights, and substitute a new concept appropriate to the conditions of the West. This they achieved, and their achievement is a significant example of the Westerner's adaptability to the conditions of his environment.

The observations of the forester, Shinn, and the engineer, Mead, were based on the specific problems in which they had a special interest, and neither drew the broader generalization which the experience of each revealed. It remained for a historian to see the wider scope of the effects of the environment upon Western social institutions.

Frederick Jackson Turner in 1903 observed that "with the advent of democracy in the last fifteen years upon the Great Plains, new physical conditions have presented themselves which have accelerated the social tendency of Western democracy. The pioneer farmer of the days of Lincoln could place his family on a flatboat, strike into the wilderness, cut out his clearing, and with little or no capital go on to the achievement of industrial independence. Even the homesteader on the Western prairies found it possible to work out a similar independent destiny, although the factor of transportation made a serious and increasing impediment to the free working-out of his individual career. But when the arid lands and the mineral resources of the Far West were reached, 
no conquest was possible by the old individual pioneer methods. Here expensive irrigation works must be constructed, co-operative activity was demanded in utilization of the water supply, capital beyond the reach of the small farmer was required. In a word, the physiographic province itself decreed that the destiny of this new frontier should be social rather than individual." 5

The passage of nearly fifty years has not affected the validity of this generalization. Rather the disappearance of easy, surface exploitation and the advance of technology have emphasized the necessity of devising new social forms to utilize and conserve the resources of the West. In addition, the concentration of economic power in private hands in the United States, which Turner foresaw, together with the threat of totalitarianism everywhere is forcing the American people to find new ways to improve the effectiveness of democratic government and safeguard individual freedom.

The West seems likely to become a new frontier of liberal thought and action in this fundamental struggle of our age. If it is to become once more a physical frontier, it must develop new techniques for effective utilization and conservation of resources by indigeneous organizations which will retain the control of the natural heritage in the hands of the people as a whole. The men and women of the Tennessee Valley deserve every recognition for having invented a new form of social organization in the regional authority. But the real test of this new social process will come when a serious attempt is made to transplant it to other regions. Liberal opinion in the Mountain West holds that the West is the region where such an attempt should be made. The analysis of the resources economist confirms the view that a period of

5 Frederick Jackson Turner: "Contributions of the West to American Democracy," The Frontier in American History (New York, Henry Holt and Company, 1920), p. $25^{8}$. 
intensive economic development may be predicted for the Mountain West. The Conservationist points to past practices and future opportunities for the growth of conservation in the West. Together these observers confirm the thesis long held by the historian-that the West exerts on American life the significant influence of the dynamic, liberal frontier.

The frontier outlook and influence have not disappeared with the disappearance of the physical frontier of the buffalo and the Indian. The West is still a frontier today, and there is reason to believe that it will continue to be a frontier in the immediate future- $\mathbf{a}$ frontier in resources development and conservation and a frontier in the evolution of liberal social processes designed to secure economic growth and security and to enlarge the economic and political freedom of the individual. 


\section{Chapter 20. A Program for Action ${ }^{1}$}

The general outline of a program for Western resources development has gradually emerged from the argument of the preceding chapters. It now seems useful to describe that program as briefly and concretely as possible. Here, then, is a twelve-point declaration of liberal economic policy for the West.

1. The extension of soil-building and anti-erosion practices to every acre of Western arable land.

2. The implementation of a broad program to increase the productive use of our forest and range reserves.

3. The continued maintenance of large areas of "wide-open space" for recreation and to protect wild life.

4. The planning of a 20-year program of exploration for minerals, using the most advanced techniques of geologic mapping, aerial survey, and geophysics.

5. The expansion of physical and economic research to discover new techniques and new markets for utilizing low-grade ores.

1 This chapter is a later and revised version of an earlier essay by the author which appeared as Chapter 9, "Economic Policy for the West" in Saving American Capitalism (Seymour E. Harris, editor; New York, Alfred A. Knopf, 1949). 
6. Construction of a greater network of dams, reservoirs, and ditches for the optimum utilization of our scarce water resources.

7. Exploitation of every potential kilowatt of hydroelectric energy, plus extension of transmission lines into new areas and new markets.

8. Development of locally managed, locally financed manufacturing industry to process Western food, fiber, and minerals.

9. Sustained and vigorous attack on institutional barriers to Western development-freight rates, monopoly control of natural resources and industrial processes, and absentee ownership both private and federal.

10. Vigilant opposition to the anti-social policies of Western minority groups-of which the wool tariff, the silver purchase program, and recent attacks on forest and grazing conservation are notorious examples.

11. The preservation of human resources by the extension of adequate facilities for education, technical training, and public health to all of the people of the region.

12. The effective co-ordination of all of the above policies by research and planning and by the establishment of regional authorities in several areas of the West.

This statement of policy can command wide agreement and wide support. But the Western liberal cannot be satisfied only by a declaration of objectives to which everyone is willing to give pious lip service. The policy must be complete and concrete, with a detailed program of action springing from it. Here, of course, major difficulties arise, notably that of developing adequate research to arrive at sound methods of development and the practical difficulty of harmonizing divergent interests and points of view to secure agreement on specific activities. Also, since this is a comprehensive and long-run program, agreement must be reached on the order of urgency of the various proposals.

Nevertheless, experience indicates many details that are sufficiently tested to provide a basis for Western liberal 
policy. These would include, in agriculture, the continued encouragement of homestead farming by maintenance, in most cases, of the 160 -acre limitation on reclamation projects and the expansion of the Water Facilities loan program of the Farm Home Administration. Both are important to improve the technical efficiency and competitive power of the family-sized farm. In forestry and grazing, first on the agenda would be to resist the selfish attempts to weaken public regulation which prevents overgrazing and preserves the natural grandeur of scenic areas. The agenda also would include reforestation, shelter-belts, and reseeding of range lands.

In the mining industry, liberal policy would advocate the gradual abandonment of subsidies and tariffs as the energy now devoted to lobbying for these ends is successfully diverted toward the enactment of state and federal legislation designed to finance and stimulate exploration and technical and economic research.

In the field of industrial development, first steps would be to create state, regional, and area Committees for $\mathrm{Re}$ sources Development; to stimulate locally owned processing plants by providing research facilities, technical assistance, and financing on a co-operative, fee basis. One of the first of these projects should be the development of a Western fertilizer industry utilizing our extensive deposits of phosphate and potash. Another would be the establishment of local plants for the grading, sorting, and processing of wool. The committees also should set up production and marketing standards for indigenous manufactures and establish Research and Development Corporations to provide venture capital for new enterprises. There is hardly a more effective obstacle to the hopes of a Western enterpriser who wishes to initiate a new small-scale business than his inability to secure adequate credit. As we have seen, much of the liquid capital of the West flows to the East and is not reinvested in the re- 
gion. Equally bad, the lending policies of the local commercial banks tend to be conservative-at least in comparison with the banks of the Pacific Coast. In Denver, for example, bank loans in the first half of 1949 were approximately 20 per cent of deposits, while in San Francisco loans were about 40 per cent of deposits. In New Mexico and Utah in 1948 the ratio of loans to deposits was somewhat higher than for all banks in the United States, but in Colorado the ratio was substantially below the national average. It is desirable that some social body should intervene in order to provide credit for indigenous enterprises, particularly in the sphere of venture capital. One way that this can be done is by government insurance of bank loans to enterprises of regional significance. Another, more direct way, is to create a mixed corporation in which the state not only advances a part of the capital but also directly participates in policy-formation and administration of the corporation. Both methods deserve a trial in the several states of the Mountain West.

The West gained a substantial victory in its attack on institutional barriers against industrialization in 1947 when the ICC Freight Rate Order of May 1945 became effective. This already-famous decision provides ultimately for a uniform system of classification on class-rate commodities for the entire United States. Thus it is a first step toward breaking down the historic freight-territories basis for rates which favors the Northeast and discriminates against the West and South. With this good beginning, Western liberals should be encouraged to demand further investigations designed to remove commodity- and exception-rate discriminations, and to extend transportation into neglected areas.

In the field of monopoly the first strategy seems to be that of specific attacks on particular monopoly barriers. Whenever a new Western firm, founded to fabricate or process a Western material, finds that patents or monopoly con- 
trols block its path, then negotiation should be brought into play, followed where necessary by anti-trust prosecution by a strengthened Department of Justice. The main attack on monopoly, however, will come from a positive program for providing capital, research, and technical assistance to small, new enterprises through private, semi-public, and public agencies such as commercial banks, co-operatives, and development corporations. It is well to observe at this point that the program is not aimed at regional self-sufficiency. The aim is to achieve regional balance, not regional autarchy. Accordingly, branches of national concerns are welcomed, and the subsidization of high-cost local enterprises is not contemplated.

All these policies for agriculture, mining, industry, and recreation are important. Yet the real key to Western development is in the optimum utilization of its resources of water and hydroelectric power. During the next half-century the irrigated areas in the entire West should be increased from 21 million acres to the economic maximum of 43 million acres. Installed power capacity should be increased by 12 million kilowatts. This would provide the base for Western industrialization and minerals development and the framework for soil and forest conservation. In fact, power and water constitute the central core around which can be built the simultaneous and integrated development of the West's varied resources.

The twelfth plank in the Western platform calls for research and planning and for the creation of regional authorities to co-ordinate the work of development and conservation now under way in the region. The reader of this book will have no difficulty in recognizing the need for further research. It is very important to assess the regional position by means of a thorough balance-of-payments study. Also the vital subject of the measure of the economic and social 
costs and benefits of specific development projects is one in which research is lacking and badly needed.

Projects like these should be financed and staffed adequately in the immediate future. For this some regional mechanism, such as a Committee for the West, is badly needed. A strong precedent for a committee of regional interest exists in the successfully functioning Committee of the South, founded in 1946 under the leadership of the National Planning Association. ${ }^{2}$ The Committee is composed of fifty-seven Southern leaders from the fields of business and industry, agriculture, labor, education, government, press, and the professions. Its research activities, under the direction of Dr. Calvin B. Hoover, eminent economist of Duke University, have yielded several studies of value to Southern development. The Mountain West needs comparable information about its own potentialities for economic growth.

\section{Western Policy and the Nation}

The proposed economic policy for the West obviously impinges directly upon national policy. In the first place, Western development directly depends upon the federal government in many respects. The federal government owns and administers 54 per cent of the area of the Western states. It controls the navigable streams. Its various regulatory agencies supervise transportation, communications, and many aspects of economic activity. Its developmental agencies, such as the Bureau of Reclamation, are engaged in improving the

2 National Planning Association, N. P. A.: Committee of the South (Washington, D. C., 1946).

Speaking in Powell, Wyoming, on September 23, 1949 Senator Joseph C. O'Mahoney referred to the work of the Committee for the South and pointed out the need for a regional study of the West, urging the immediate creation of a Committee for the West. (The Denver Post, September 24, 1949). 
West's resources. It follows that the achievement of Western economic development will depend largely upon national policies. The liberal West asks, therefore, for a sympathetic understanding of its problems by Americans everywhere.

In return the West offers to the rest of the nation its very substantial contribution to the national welfare. Its development will contribute a very significant amount to the nation's wealth, which will help to raise per capita income not only in the West, but in the nation as a whole.

Equally important, development of the West will help to stabilize the national economy by providing an economically sound outlet for investment of capital funds, by stabilizing regional incomes, and by reducing regional underemployment and unemployment. These gains will result, in turn, in the more equitable distribution of national income, which is a primary requisite of economic stability.

Finally, developing the West can contribute to national welfare because of its emphasis upon the principle of decentralization. Physical decentralization is a necessity of the atomic age; but the philosophy of decentralization has much broader implications than the physical. The West can accommodate several million more people with no loss in the present high enjoyment of life by Westerners, and with better and happier living for many inhabitants of the typical congested urban area. More important still, development of the West by regional authorities, firmly based on the people, will do much to push back upon the region, the local government, and the individual citizen the responsibility and opportunity for self-government and for democratic control of our economic destinies.

The West is still a land of opportunity. It is large and underdeveloped. It particularly lacks in manufacturing, and its economy is unbalanced and unstable-too dependent on the whims of Nature. An economic policy for the West 
should be directed to conserve and develop its great resources and particularly toward the processing of its own food, fiber, and minerals. Such industrialization should be encouraged by state and regional committees for research, financing, and other services and by locally inspired attacks on the institutional barriers to economic expansion. In particular the semiarid West must expand the use of its water and power resources through the establishment of regional authorities. If properly implemented these policies will result in population growth, greater stability in the regional economy, a rise in per capita income, and an increase in the region's contribution to the wealth and security of the American people. 
- 


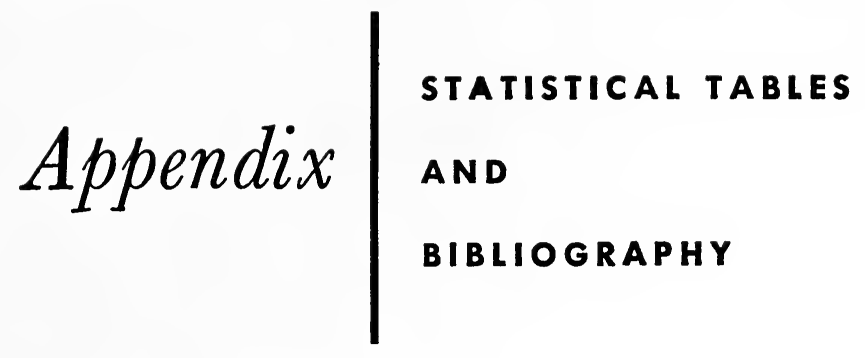



TABLE 14: Impact of the War on the Mountain West-in Terms of Direct Changes in Regional Economic Activity and Relative Changes in the Region's Share of Total National Activity. ${ }^{1}$

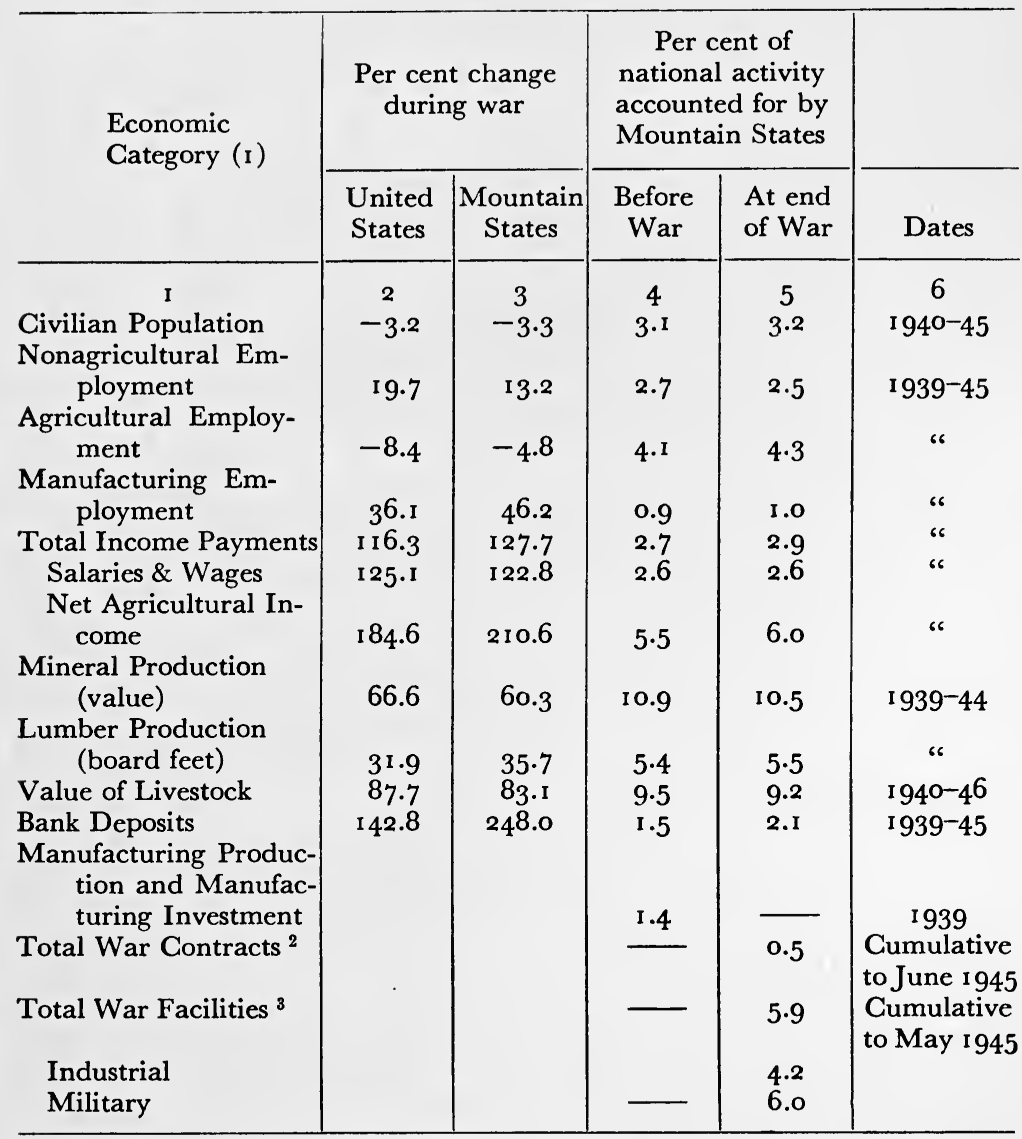

${ }^{1}$ United States Department of Commerce: State and Regional Market Indicators: $1939-1945$. Economic Series No. 6o. (Washington, D. C., U. S. Government Printing Office, I947).

2 Glenn McLaughlin: "Regional Problems of Industrialization" in Economic Reconstruction. Seymour Edwin Harris, editor (New York, McGraw-Hill Book Company, 1945), Table 3, p. 167.

${ }^{3}$ War Assets Administration, Office of Real Property Disposal: The Plant-Finder (Washington, D. C., June I 947). 


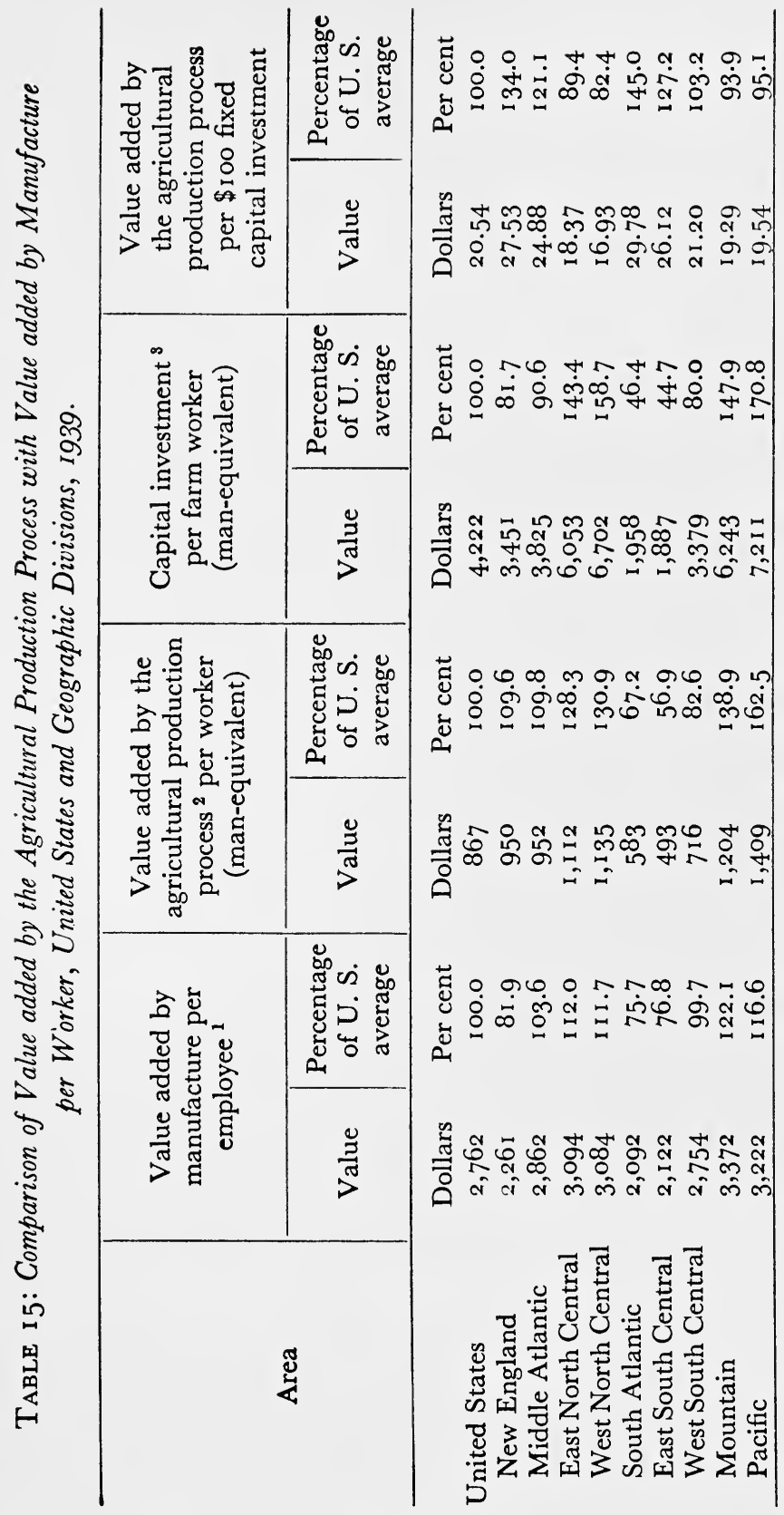

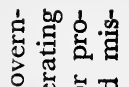

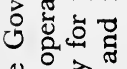

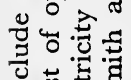
若苍苞 $\circ$ 월

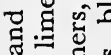

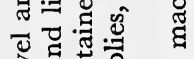

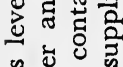
ก एँ ह

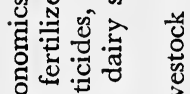

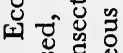
तี สิ $\Xi$ प 㝴总焉 כ2, 造过 ส

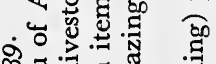

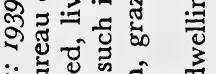

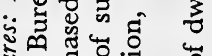
इ0

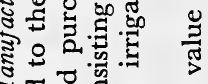

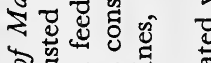

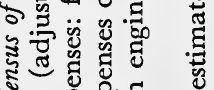
डั ฐ की

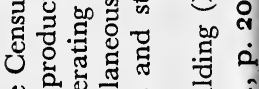
ङ Ч इ Јี ప్రై पे

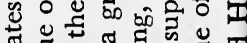

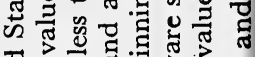

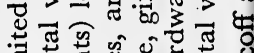

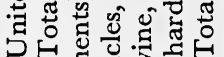

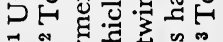

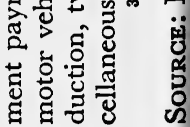


TABLE 16: Sex and Race by States (rg4o).

\begin{tabular}{|c|c|c|c|}
\hline & All & Native White & Foreign-Born \\
\hline & $\begin{array}{l}\text { Males per } \\
\text { I oo Females }\end{array}$ & $\begin{array}{c}\text { Males per } \\
\text { Ioo Females }\end{array}$ & $\begin{array}{c}\text { Males per } \\
\text { Ioo Females }\end{array}$ \\
\hline United States & 100.7 & IOO.I & I I I.I \\
\hline Mountain States & 107.4 & 105.9 & I3O. I \\
\hline Montana & I I 4.8 & I I I .8 & I 46.5 \\
\hline Idaho & I I I 4 & I09.7 & I $49 \cdot 7$ \\
\hline Wyoming & I 16.7 & I I 4.0 & 162.0 \\
\hline Colorado & 102.6 & 101.2 & I 26.2 \\
\hline New Mexico & I 04.6 & 103.8 & I 26.4 \\
\hline Arizona & 107.1 & г 06.6 & I04.I \\
\hline Utah & I 02.6 & I02.I & 105.4 \\
\hline Nevada & I 25.4 & I I 9.9 & I98.3 \\
\hline
\end{tabular}

Source: United States Bureau of the Census: Statistical Abstract of the United States: 1946, Table No. 20.

TABle I7: Population of the Mountain West by Certain Age Groups, by Sex, 1940.

\begin{tabular}{l|l|l}
\hline Age \& Sex & Number & Per cent by Age \\
\hline
\end{tabular}

All

$\begin{array}{rrr}\mathrm{O}^{-\mathrm{I} 4} & \mathrm{I}, \mathrm{I} 82,088 & 28.48 \\ \mathrm{I} 5^{-64} & 2,7 \mathrm{I} 6,754 & 65.46 \\ 65^{-} & 25 \mathrm{I}, \mathrm{I} 6 \mathrm{I} & 6.05\end{array}$

Male

$\begin{array}{rrr}\mathrm{O}^{-1} 4 & 598,894 & \mathrm{I} 4.43 \\ \mathrm{I}^{-64} & \mathrm{I}, 4^{\mathrm{I}} 4,572 & 34.09 \\ 65^{-} & \mathrm{I} 35,93^{-} & 3.28\end{array}$

Female

$\begin{array}{rrr}0-14 & 583,194 & \text { I } 4.05 \\ \text { I 5-64 } & \text { I,302, I } 82 & 31.38 \\ 65^{-} & \text {I I } 5,229 & 2.78\end{array}$

Source: Population, Vol. II. "Characteristics of the Population." 
TABLE 18: Number and Per cent of White Population of the Mountain West reporting Spanish as the Mother Tongue, by States, 1940.

\begin{tabular}{l|r|r|r}
\hline \multicolumn{1}{c|}{ State } & $\begin{array}{c}\text { Spanish- } \\
\text { Speaking }\end{array}$ & $\begin{array}{c}\text { Total White } \\
\text { Population }\end{array}$ & $\begin{array}{r}\text { Per cent } \\
\text { Spanish- } \\
\text { Speaking }\end{array}$ \\
\hline New Mexico & 221,740 & 492,000 & 45.07 \\
Arizona & IOI,880 & 426,700 & 23.88 \\
Colorado & 92,540 & I, I O6,400 & 8.36 \\
Wyoming & 6,140 & 247,060 & 2.49 \\
Nevada & 3,060 & 104,500 & 2.93 \\
Idaho & 2,720 & 519,540 & .52 \\
Utah & 2,580 & 544,480 & .47 \\
Montana & 2,240 & 540,560 & .41
\end{tabular}

Source: United States Bureau of the Census: Population-Nativity and Parentage of the White Population: Mother Tongue. 16th Census of the United States: I 940. 


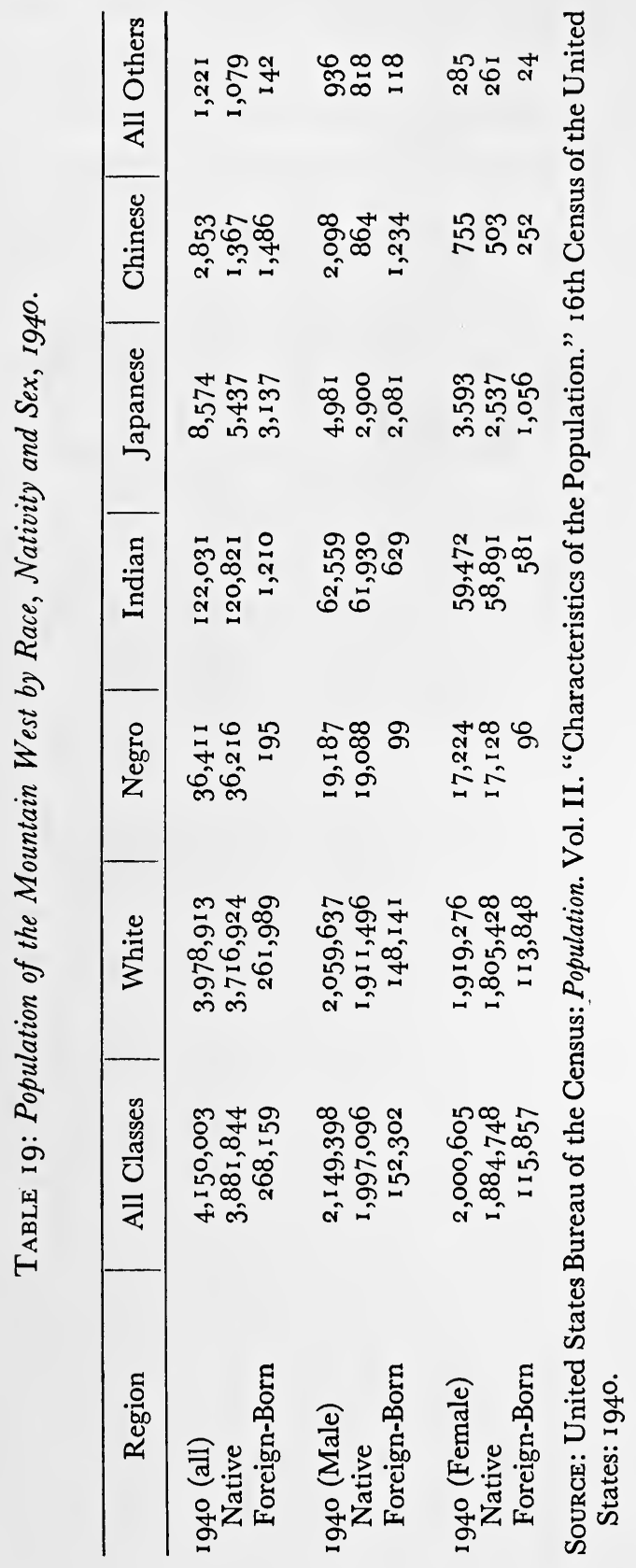


TABLE 20: Estimated Annual Average Net Migration, for the Mountain West and Component States. ${ }^{1}$

\begin{tabular}{|c|c|c|c|}
\hline & Pre-war & World War II & Post-war \\
\hline Region and State & $\begin{array}{c}\text { April I, I } 940 \\
\text { to } \\
\text { June } 30, \text { I } 941\end{array}$ & $\begin{array}{c}\text { July I, I } 94 \text { I } \\
\text { to } \\
\text { June 3o, I945 }\end{array}$ & $\begin{array}{c}\text { July } \mathrm{r}, \mathrm{I} 945 \\
\text { to } \\
\text { June } 30,1947\end{array}$ \\
\hline \multicolumn{4}{|l|}{ Mountain West } \\
\hline Montana & $-6,000$ & $-25,000$ & $-3,000$ \\
\hline Idaho & $-6,000$ & $-7,000$ & $-9,000$ \\
\hline Wyoming & $+6,000$ & $-4,000$ & $-4,000$ \\
\hline Colorado & $+12,000$ & $-24,000$ & $-\mathrm{I}, \mathrm{OOO}$ \\
\hline New Mexico & $-2,000$ & $-19,000$ & $+1,000$ \\
\hline Arizona & $+18,000$ & $+8,000$ & $+\mathrm{I} 7,000$ \\
\hline Utah & $+9,000$ & $+4,000$ & $-8,000$ \\
\hline Nevada & $+6,000$ & $+3,000$ & $+2,000$ \\
\hline
\end{tabular}

1 United States Bureau of the Census: Current Population Reports: Population Estimates. Series P-25, No. 12 (Washington, D. C., August 9, 1948), Table 5. 
TABLE 21 : Percentage of Total Labor Force Employed in Mining and Manufacturing, 1880 to 1940 .

\begin{tabular}{|c|c|c|c|c|c|c|}
\hline I 880 & \multicolumn{2}{|c|}{ 189o } & \multicolumn{2}{|c|}{1900} & \multicolumn{2}{|c|}{ Igro } \\
\hline $\begin{array}{c}\text { Min- Manu- } \\
\text { ing factur- } \\
\text { ing }\end{array}$ & $\begin{array}{l}\text { Min } \\
\text { ing }\end{array}$ & $\begin{array}{l}\text { Manu- } \\
\text { factur- } \\
\text { ing }\end{array}$ & $\begin{array}{l}\text { Min } \\
\text { ing }\end{array}$ & $\begin{array}{l}\text { Manu- } \\
\text { factur- } \\
\text { ing }\end{array}$ & $\begin{array}{l}\text { Min- } \\
\text { ing }\end{array}$ & $\begin{array}{l}\text { Manu- } \\
\text { factur- } \\
\text { ing }\end{array}$ \\
\hline I 5.9 & 14.6 & 12.4 & I 5.3 & I 5.8 & I 7.9 & I6.7 \\
\hline 15.1 & I I.O & I6.3 & 13.9 & 16.7 & 8.4 & 16.3 \\
\hline I 1.5 & 14.9 & 10.9 & 11.8 & IO.I & 5.1 & 12.3 \\
\hline 13.6 & 15.2 & 15.3 & 15.2 & 15.9 & 10.9 & I 3.9 \\
\hline 18.7 & 20.8 & 12.8 & 13.9 & 12.7 & 21.9 & 12.5 \\
\hline I6.6 & $5 \cdot 7$ & 12.3 & 6.9 & I 3.9 & 5.0 & IO.I \\
\hline 18.2 & $5 \cdot 7$ & I6.3 & 8.4 & 14.5 & 7.7 & 17.0 \\
\hline I 9.6 & 10.4 & 15.0 & $9 \cdot 4$ & I 3.9 & I 1.0 & I 1.6 \\
\hline I 6.0 & I I.2 & 14.9 & 12.4 & I 5.0 & $9 \cdot 4$ & 14.4 \\
\hline 19.2 & 1.7 & 20.2 & 2.1 & 20.8 & 2.5 & 23.1 \\
\hline I 920 & & & & & 194 & \\
\hline
\end{tabular}

Manu- Manu- Manu-

Arizona

Colorado

Idaho

Montana

Nevada

New Mexico

Utah

Wyoming

Mountain Region

United States

Mining facturing

Mining facturing

Mining facturing

Arizona

Colorado

Idaho

Montana

Nevada

New Mexico

Utah

Wyoming

Mountain Region

United States

$\begin{array}{rr}12.5 & 15.0 \\ 6.4 & 15.9 \\ 3.3 & 11.8 \\ 7.8 & 11.6 \\ 16.4 & 15.4 \\ 6.2 & 11.1 \\ 6.8 & 17.5 \\ 10.9 & 14.4 \\ 7.5 & 14.2 \\ 2.6 & 26.4\end{array}$

$\begin{array}{rr}10.6 & 10.9 \\ 5.0 & 11.4 \\ 4.0 & 8.9 \\ 8.2 & 8.4 \\ 14.1 & 7.5 \\ 5.6 & 6.6 \\ 7.4 & 12.7 \\ 8.6 & 7.8 \\ 6.9 & 9.9 \\ 2.4 & 22.8\end{array}$

$8.5 \quad 8.4$

$4.5 \quad 10.2$

$4.2 \quad 7.9$

$7 \cdot 3 \quad 7.4$

15.1 4.5

$6.3 \quad 6.4$

$6.7 \quad 11.0$

$7 \cdot 3 \quad 5 \cdot 3$

$6.4 \quad 8.4$

$2.0 \quad 23.4$

Source: United States Bureau of the Census: Population Reports. I I th through the 16 th Census of the United States: 1890-1940. 


\section{Selected Bibliography}

Many aspects of the economy of the Mountain West are touched upon in numerous books and documents. Where direct reference to a specific source has been made the item is described in a footnote to the text. However, a multitude of other references of value for this study were consulted from time to time. The most significant of these compose this selected bibliography.

\section{Books}

Appleby, Paul H.: Big Democracy. New York: Alfred A. Knopf; 1945, 197 pp.

Atwood, Wallace W.: The Rocky Mountains. New York: The Vanguard Press; 1945, 324 pp.

Bean, Lours H.: How to Predict Elections. New York: Alfred A. Knopf; 1948, 196 pp.

Berge, Wendell: Economic Freedom for the West. Lincoln, Neb.: University of Nebraska Press; 1946, 168 pp.

Burns, Arthur R.: The Decline of Competition. New York: McGrawHill Book Company, Inc.; 1936, 619 pp.

Butler, Ovid: American Conservation. Washington, D. C.: The American Forestry Association; 1935, 144 pp.

Davidson, Donald: The Attack on Leviathan, Regionalism and $\mathrm{Na}$ tionalism in the United States. Chapel Hill, N. C.: The University of North Carolina Press; 1938, 368 pp.

Dean, William H., JR.: The Theory of the Geographic Location of Economic Activities. Ann Arbor, Mich.: Edward Brothers, Inc.; 1938, 46 pp.

Fergusson, Harvey: People and Power, A Study of Political Behavior in America. New York: William Morrow and Company; 1947, $241 \mathrm{pp}$. 
Fetter, Frank Albert: The Masquerade of Monopoly. New York:

Harcourt, Brace and Co.; 1931, 464 pp.

Hafen, Leroy R. and Rister, Carl Coke: Western America. New York: Prentice-Hall, Inc.; 1941, $698 \mathrm{pp}$.

Herring, Pendleton: The Politics of Democracy. New York: Rinehart and Company, Inc.; 1940, 468 pp.

Holcombe, Arthur N.: The New Party Politics. New York: W. W.

Norton and Company, Inc.; 1933, $14^{8}$ pp.

Laski, Harold Joseph: The American Democracy. New York: The Viking Press, Inc.; 1948, $78_{5}$ pp.

Lauterbach, Albert: Economic Security and Individual Freedom: Can We Have Both? Ithaca, N. Y.: Cornell University Press; 1948, $178 \mathrm{pp}$.

Leavens, Dickson H.: Silver Money. Bloomington, Ill.: Principia Press, Inc.; 1939, 439 pp.

Lilienthal, David E.: TVA, Democracy on the March. New York: Harper and Brothers Publishers; 1944, 248 pp.

Lillard, Richard G.: The Great Forest. New York: Alfred A. Knopf: 1947, 399 pp.

McCune, Wesley: The Farm Bloc. Garden City, N. Y.: Doubleday, Doran and Company, Inc.; 1943, 278 pp.

McLaughlin, Glenn E.: Growth of American Manufacturing Areas. Pittsburgh: Bureau of Business Research, University of Pittsburgh; 1938, 359 pp.

McWilliams, Carey: The New Regionalism in American Literature.

Seattle, Wash.: University of Washington Book Store; 1930, 39 pp.

Mezerik, A. G.: The Revolt of the South and West. New York: Duell, Sloan, and Pearce; 1946, 290 pp.

MOORE, HARRY E.: What Is Regionalism? Chapel Hill, N. C.: The University of North Carolina Press; 1937, 16 pp.

Odum, Howard W. and Moore, Harry Estill: American Regionalism. New York: Henry Holt and Company; 1938, 693 pp.

Ohlin, BertiL: Interregional and International Trade. Cambridge, Mass.: Harvard University Press; 1933, 617 pp.

Parish, John Carl: The Persistence of the Westward Movement and Other Essays. Los Angeles: University of California Press; 1943, $187 \mathrm{pp}$.

Paxson, Frederic Logan: The Last American Frontier. New York: The Macmillan Company; 1930, 402 pp.

Rosenfarb, Joseph: Freedom and the Administrative State. New York: Harper and Brothers Publishers; 1948, 274 pp.

Schlesinger, Arthur M., JR.: The Age of Jackson. Boston: Little, Brown and Company; 1946, 577 pp. 
Stigler, George J.: Trends in Output and Employment. New York: National Bureau of Economic Research; 1947, 67 pp.

Turner, Frederick Jackson: The Frontier in American History. New York: Henry Holt and Company; 1920, 375 pp.

-: The Significance of Sections in American History. New York: Henry Holt and Company; 1932, 347 pp.

Vogt, William: Road to Survival. New York: William Sloane Associates, Inc., Publishers; 1948, 335 pp.

Woods, Rurus: The 23-Years' Battle for Grand Coulee Dam. Wenatchee, Wash.: Wenatchee Daily World; 1944, 82 pp.

\section{Government Publications}

National Resources Committee: Regional Factors in National Planning. Washington, D. C.: United States Government Printing Office; 1935 .

National Resources Planning Board: Area Analysis-A Method of Public Works Planning. Technical Paper No. 6. Washington, D. C.:

- United States Government Printing Office; 1943.

- Industrial Location and National Resources. Washington, D. C.: United States Government Printing Office; 1943.

-: Mountain States Region Industrial Development. Washington, D. C.: United States Government Printing Office; 1942.

-: Regional Development Plan Report for 1942: Mountain States. Preliminary statement, regional development plan. Denver, Colo.; 1941.

—: Regional Planning. Part XII. The Arkansas Valley. Washington, D. C.: United States Government Printing Office; 1942.

United States Department of Agriculture: Irrigation Agriculture in the West. Miscellaneous Publication No. 67o. Washington, D. C.; (November 1948).

United States Department of the Interior, Bureau of Reclamation: The Colorado River. Washington, D. C.; (March 1946).

- Potential Water Power in the United States. Washington, D. C.; (January 1935).

—: Potential Water Power in the United States: 1946. Washington, D. C.; n.d.

- Report of the Secretary of the Interior on the Synthetic Liquid Fuels Act: 1947. Washington, D. C.; 1948.

United States House Document No. 264, 75 Congress, 1 Session: Interterritorial Freight Rate Problem of United States. Washington, D. C.: United States Government Printing Office; 1937. 
United States House Document No. 238, 73 Congress, 2 Session: Missouri River. Washington, D. C.: United States Government Printing Office; 1935 .

United States House Document No. 475, 78 Congress, 2 Session: Missouri River Basin. Washington, D. C.: United States Government Printing Office; 1944, (The Pick Plan).

United States House Document No. 137, 78 Congress, 1 Session: Regionalized Freight Rates. Washington, D. C.: United States Government Printing Office; 1943 .

United States House Document No. 303, 78 Congress, 1 Session: Report on Interterritorial Freight Rates. Washington, D. C.: United States Government Printing Office; 1943.

United States House Document No. 145, 78 Congress, 1 Session: Summary Report on Study of Interterritorial Freight Rates. Washington, D. C.: United States Government Printing Office; 1943.

United States Senate Committee on Agriculture and Forestry: Price Support Program for Wool. Hearings before the Committee on Agriculture and Forestry. 8o Congress, 1 Session. Washington, D. C.: United States Government Printing Office; 1947.

United States Senate Document No. 140, 79 Congress, 2 Session: $A n$ Effective Wool Program. Washington, D. C.: United States Government Printing Office; 1946.

United States Senate Document No. 191, 78 Congress, 2 Session: Missouri River Basin. Washington, D. C.: United States Government Printing Office; 1944, (The Sloan Plan).

United States Senate Document No. 247, 78 Congress, 2 Session: Missouri River Basin. Washington, D. C.: United States Government Printing Office; 1944, (The Compromise Pick-Sloan Plan).

United States Senate Report No. 578, 8o Congress, 1 Session: Sugar Act of 1948 . Washington, D. C.: United States Government Printing Office; 1948.

United States Temporary National Economic Committee: Investigation of Concentration of Economic Power. Monograph No. 42. The Basing Point Problem. Washington, D. C.: United States Government Printing Office; 1941 .

Work Projects Administration, Federal Works Agency: Rural Regions of the United States. Washington, D. C.: United States Government Printing Office; 1940.

\section{Periodical Literature}

Blair, John M.: "Does Large-scale Enterprise Result in Lower Costs?" American Economic Review, 38:121-64, (May 1948). 
Bontright, Mody: "The Myth of Frontier Individualism," The Southwestern Social Science Quarterly, 22:14-32, (June 1941).

Caldwell, Lynton K.: "Interstate Cooperation in River Basin Development," Iowa Law Review, 32:232-43, (January 1947).

Daggett, Stuart: "Interterritorial Freight Rates and the Pacific Coast," Law and Contemporary Problems, 12:60o-20, (Summer 1947).

Fetter, Frank A.: "Exit Basing Point Pricing," The American Economic Review, 32:815-27, (December 1948).

Friedrich, Julius M.: "The Settlement of Disputes between States Concerning Rights to the Waters of Interstate Streams," Iowa Law Review, 32:244-82, (January 1947).

Hagood, Margaret Jarman: "Statistical Methods for Delineation of Regions Applied to Data on Agriculture and Population," Social Forces, 21:287-97, (March 1943).

"How Farm Machinery Got Started," Through the Leaves, 35:48-51, (July-August 1947).

Locklin, D. Philip: "Can Existing Regional Differences in Class-rate Levels Be Justified?" Law and Contemporary Problems, 12:495-506, (Summer 1947).

Lösch, August: "The Nature of Economic Regions," The Southern Economic Journal, 5:71-8, (July 1938).

McCarran, Pat: "The New 'Crime' of Silver: Who's Guilty-The Producers' Side," Mining and Metallurgy, 28:10-11 and 13 (January 1947).

McDill, Ellis: "No More Hand Harvesting For Us," Through the Leaves, 25:26-8, (September-October 1947).

Odum, Howard W. and Jocher, Katherine: "In Search of the Regional Balance of America." Part I. "From Empirical Studies to Regionalism," Social Forces, 23:245-328, (March 1945).

Schlesinger, Arthur M: "Tides of American Politics," The Yale Review, new series, 24:217-30, (December 1939).

Shryock, Henry S., Jr. and Eldridge, Hope Tisdale: "Internal Migration in Peace and War," American Sociological Review, 12:27-39, (February 1947).

Van Sickle, J. V.: "Regionalism: A Tool of Economic Analysis," American Economic Review, 35:355-67, (May 1945).

Weeks, Sinclair: "The New 'Crime' of Silver: Who's Guilty-The Consumers' Side," Mining and Metallurgy, 28:11-12 and 14, (January 1947).

White, LANGdon: "The Insular Integrity of Industry in the Salt Lake Oasis," Economic Geography, 1:206-35, (March 1925). 


\section{Index:}

Agriculture: crop land increase, 30-1; high productivity, 31-3; in Mountain West, 44-8; destructive use of soil, 57; land utilization, present and potential, 64, 65; effect on income of Mountain West, 131-2; productivity, 148; Montana programs, 276-7; basis for liberal policy in, 294; water facilities loan program, 294; homestead farming, 294; see also Irrigation, and Dryland Farming

Albuquerque, industrial center, 104

Alcohol, Washington reconversion, 25

Aluminium, Washington reconversion, 25

American Economic Association, see Silver

American Meat Institute, 206

American National Livestock Association, 205, 206

America's Needs and Resources: a high level economy, 29-30; agriculture, 30-1; mineral energy, 34-5

Anaconda Copper Company, 161, 262

Anglo-American culture, in Mountain West, 54

Arco, Idaho, 67

Arizona: Mountain West, 11; Tucson, 75; deviation from United States industrial pattern, 102; Phoenix, 104; income from manufacturing, 131, from trade and services, 132, from government, 133; causes of per capita income level, 137; Tonto
Arizona (continued)

National Forest, 207; Colorado River Compact, 248

Arkansas, manufacturing income, 131

Arkansas River: population concentration, 73; fight over, 246

Army Engineers, Corps of, see Corps of Army Engineers

Atomic Energy, and hydroelectric power, $67-8$

Atomic Energy Commission, Hanford, Arco, Oak Ridge, 68

Banks: local lending policies, 295; government insurance of loans, 295 ; see also Industrial Development

Barrett, Frank A., 208

Barton, Frank L., 177

Bashore, Harry W., 248

Basic Magnesium Incorporated, reconverted, 25

Basing-Point Pricing: steel, 182; gasoline, 182 ; sugar, $182,185^{-6}$; discriminatory effects of, 183,187 ; beneficiaries of, 183-4; regional fabricators of steel, 186-7; United States $v$. the Cement Institute, 181; cement manufacturers, 181; sugar beet processors, 181

Bean, Louis, Dr., 30

Beckley, W. S., Ranger, 212

Beet Growers Marketing Association, Mountain States, see Sugar Act

Beet Sugar Industry: migratory labor, 84 ; locational factors, 106, 108, 109; 
Beet Sugar Industry (continued)

capital investment per worker, 151; effect of Basing-Point Pricing on, $183,185-6$; important income for farmers, 219; integration with Western agriculture, 219; labor conditions in, 220, 225-6; methods of cultivation, 221; mechanization, 222; lobbying, 224; and tariffs, 227; competitive costs, $227-8$

Berge, Wendell, 261

Bill of Rights, A New, 283

Boettcher, Charles E., 218

Blakey, Roy, 228

Blocs, Special-Interest, see Special-Interest Blocs

Bryan, William Jennings, 17, 197-8, 231

Bryce, James, 55

Buffalo, 12; extermination of, uses of, $5^{6-7}$

"building ahead of the traffic": railroads, 15; dams and power plant, 272

Bureau of Labor Statistics, 93

Bureau of Mines: Shale-oil, J. D. Lankford, 27; pilot plant for shaleoil, 61 ; opposed 1948 minerals subsidy bill, 200

Bureau of Reclamation: Rio Grande Conservancy District; Elephant Butte Dam, 83; Pick-Sloan compromise, 252; capital investment of, 268; as a development agency, 297

Butte, Montana, 75, 262

California: Westward Movement, 3; Far West, 10; reconversion, 25; water demands on Colorado River, 27; Colorado River Compact, 26; manufacturing income, trade and services income, 131-2; fight over Colorado River water, 247; see also Far West

Candy Industry, see Sugar Beet Industry

Capehart Committee, 181, 186, 188

Capital Investment: flow of, 15; mechanization of agriculture, 148; irrigation, 149; in manufacturing, 151; beet sugar refining, 151; steel, 151; relation to per capita income, $15^{1}$; in sugar beet cultivation, 222; in a regional program for the Mountain West, 268-71; lending policies, 295; by government agencies, 295

Capital Investment in Mountain West: lagging, 267; reclamation,
Capital Investment in Mountain West (continued)

268; power, 268; shale-oil, 268; soil conservation, 268; phosphate, 268; potential Federal, 268-70, effects of, $269-71$; relation of regional to national, $269-72$

Carlsbad, New Mexico, 75

Cement Institute v. United States, see Basing-Point Pricing

Center of population, see Population

Chavez, Dennis, 26o

Class Rate decision (May 12, 1947) and regional freight rate discrimination, 178; effects of, 180

Clayton, Will, Under Secretary, 202

Climate, 17, 42-4; effects on economy of Mountain West, 44; effect on agriculture, 65; see also Topography, and Living Conditions and Climate

Coal: labor's demands, 17; reserves of, 34 , 6o; effects of geological forces, 50

Colorado: Mountain West, 11; Rocky Mountain Arsenal, 24; Pueblo, 24; reconversion, 24; Colorado River rights, 26; shale-oil, 26; population concentration, 73; deviation from United States industrial pattern, 102; primary manufacturing nucleus, 102; Denver-Pueblo, 104; Pueblo Ordnance Depot, 111; per capital fuel consumption, 112; income from manufacturing, 131, from agriculture, 130, from trade and services, 132, from government, 133; per capita income, 137; fight over Arkansas River, 246; Colorado River, 248; University of, 262; banks, 295; see also Denver

Colorado Fuel and Iron Company: Rocky Mountain Arsenal, 24; freight rates, 177,182

Colorado Rancher and Farmer, 21314

Colorado River, fight for its waters, 26, 247

Colorado River Compact, 26, 248

Columbia Basin, hydroelectric power program, $3^{6}$

Commissioner of Indian Affairs, 8o

Committees for Resource Development, see Industrial Development

Committee for the South, 263, 297

Commodity Credit Corporation, 202

Concentration of power, see Locus of power 
Conference on Trade and Employment, Geneva International, see Wool

Connecticut, manufacturing income, 131

Conservation, 5, 17; Gifford Pinchot, 55, 274-5; Theodore Roosevelt, 55; lacking in early periods, $5^{8}$; need for a minerals program of, 200; of grazing land, 205, 217 ; of soil, 2768; of natural resources, 276 ; see also Forest Service, and Development program for Mountain West

Conservation Movement: Mountain West the leader in, 272; three reasons for believing so, 273-6; Montana agricultural programs, 276-7; Dust Bowl, 278; effect of World War II on, 278; man against nature, 279; man against man, 279; see also Development Program for the Mountain West

Conservation of Natural Resources: as a new liberal political issue, 239; a twentieth-century idea, 239; based on necessity, 239; of universal concern, 239; development and, 273-7; see also Conservation, Economic Control, Economic Expansion, and Western Liberalism

Cook, John R., 56

Copper: 17, 156, 157, 159; reserves of, 6o; Kennecott Copper Company, 115: Anaconda Copper Company, 161

Corps of Army Engineers: Pick-Sloan Plan, 252; navigation channel, 1946 , 254; see also Missouri Valley Authority, and Bureau of Reclamation

Culture of Mountain West: Indian, 54; Mormon, 54; Spanish, 54; Exploitation as a cultural trait, $55^{-8}$

Decentralization of power, see Locus of power

Decentralization, principle of, 298

Denver, Colorado: industrial power cost high, 112; meat-packing industry, 113; experimental wool scouring plant, 115; University of, 262; see also Colorado

Denver Post, 211 , 26o

Developmental Program for Mountain West: rebirth of the frontier spirit, 271-2; conservation and developinent of natural resources, 268-9, 273; the unified attack, 274; general outline of, 292; adequate
Developmental Program for Mountain West (continued)

research, 293; resolve conflict, 293; basis for liberal policy in agriculture, 293-4; Forestry, 294; Mining, 294; Industrial Development, 294; venture capital, 294; banks, 295, monopoly, 295-6; water and hydroelectric power, 296; committee for the West, 297; dependence on federal government policies, 298 ; results of a, 298

Dewhurst, J. Frederick, 34

Dick, Everett, 57

Distribution facilities, see Markets and Distribution facilities

Douglas, Lynn, 213

Dry-land farming, 17; return to pasture, 32; see also Agriculture

Duke University, see Committee for the South

Dust Bowl, 5, 278, 279

East vs. West, see Western Liberalism

Economic Freedom, ways to maintain, 283-4

Economic Policy of Mountain West, see Developmental Program for Mountain West

Economy of Mountain West: growth of, 13, 16; decline of, 22; topography and climate, effects on, 44; exploitation, 55-8; employment, 93-8; industrial unbalance, 100

Elephant Butte Dam, 83

Ely, Nevada, 75

Employment: during the war, 94-5; in $1950,9^{6-8}$

Employment, Act of 1946, 241

Erosion: effects of on minerals, 50; Spanish-American farms, 84

Far West: Westward Movement, natural advantages, 4 ; birth of, boundaries of, climate, 9, 10; population increase, 19, 20; income increase, 25; reconversion, 25; power cost, 112; post-war expansion, 119; income rising, 27-8, income per capita, 141, banks, 295; see also California, Oregon, Washington

Farm Bloc: and silver lobby, 196; and wool lobby, 202

Farm Home Administration, 294

Farmers Union (Farmers Educational and Co-operative Union of America), $114,208,241$

Federal Government, see Government, Federal 
Fertilizers, see Potash and Phosphate Fetter, Frank A., 188

Flood Control Act of 1945, the O'Mahoney-Milliken Amendment, 253

Florida: phosphate rock deposits, 114; Victor Chemical Works, 114

Fontana steel, reconversion, 25

Forest Act of 1897,216

Forest Service: administration of grazing permits, 211-3; attacks on, 20711

Forest Service Bill (October, 1949), 209-10

Forests: idle reserves of, 3; and the economy, 10; watershed, $48-50$; primary use, 61; secondary, 62; reserves of, 62; uses of Roosevelt National Forest, 211-2, 216; basis for liberal policy in, 296

Free land policy, influence of, 13

Freedom from Want, see Bill of Rights

Freight Rates: a factor in Western expansion, 4; meat packing industry, Denver, 114; Interstate Commerce Commission investigations, 169; nature and system of, 170; discriminatory character, 171, 177-9; revisions of, in meat-packing, 1714; preferential rates, 180

Frontier: advance of, 3, 9; closed, 10; products of, 12; advances, 19; see also Westward Movement

Furs, 12

Fuels, see Petroleum, Coal, Shale-oil

Gasoline, production and consumption, 158; basing-point pricing, 182

Geneva International Conference on Trade and Employment, 202

Geneva Steel Plant of Provo, Utah, reconverted, 24

Gila River, 73

Glazier, Wm., 225

Gold, 5, 12; effects of geological forces, $5^{\circ}$; reserves of, 6o; exports of, 156

Gold standard, 17, 198

Government, Federal: role of, 5, 2823; land policy, 13, railroads, 14; effect on income payments, 134-6; effect on regional balance of payments, 163-5, 167; investment in Mountain States, 268-71

Granger Movement, 169, 231

Grazing fees, 210

Grand Junction, Colorado, 208

Greeley, Horace, 9, 38, 77

Gress, W. B., 226
Gross regional product, 157

Gulf Southwest, has natural advantages, 4; see also Texas

Gunther, John (Inside U.S. A.), 11 , 196, 262

Hanford, Washington, and power reserves, 272

Haystead, Ladd, 261

Hemtsman Echo, 57

Hispanic-Americans, see SpanishAmericans

Homestead Act, 1862, 13-4

Hoover Commission Report (1949):

Pick-Sloan Plan, 252, 253; interagency committees, 256

Hoover, Calvin B., Dr., 297

Hoover, Edgar H., 188

Howard, Joseph Kinsey, 261

Hoyt, Palmer, 260

Hull, Cordell, 202

Hummel, Paul, 212

Hunt, Lester C., 262

Hydroelectric power, 4; potential of Mountain West, 36; Tennessee Valley Authority, 36; Columbia Basin, 36; private power interests, 37 ; Snake River, 67; Arco Idaho, 67; private utilities bloc, 234; key to Western development, 296; see also Industry, Water, Rainfall, and Irrigation

Idaho: Mountain West, 11; Arco, atomic energy experimental plant, 67; deviation from United States industrial pattern, 101; income from manufacturing, 131, from trade and services, 132; per capita income, 137

Income payments: per capita in West, 20, 22, 125; regional share, 125; trends in, 125-9; New England, 127; Middle Atlantic, 127; East South Central, 128; major sources of, 129; manufacturing, 131; agricultural, 131-2; trade and service, 132; government payments, 133; private payments, 136; per capita by states, 137-8; stability of, 138-9; relation to productivity, 141-2, 152-3; relation to exports of funds, 159; effect of freight rates on, 174

Indian: culture in Mountain West, 54; Commissioner of Indian Affairs, 80 ; poverty of, 80 ; income, 82 ; Navaho, 82; soil depleted, 80 ; secondclass citizen, 86 
Industrial Development: employment, 95, 96; basis for liberal policy in, 294; committees for Resource Development, 294; phosphates, 294; potash, 294, wool, 294; venture capital, 294; banks, 295, institutional barriers, 294; see also Manufacturing

Industrial fuel and power, 112-3

Industrial location factors: location of production materials, 108; labor, 109; sites, 111 ; industrial fuel, $111-$ 3; transportation facilities, 113-4; market, 113-4; distribution facilities, 114-5; power, 112; water, $115^{-}$ 6; living conditions, 116; laws and regulations, 116-7; tax structure, 117; climate, 116; localized, 105; non-localized, 105; freight rate differentials, 108; basing point system, 108; inertia, 108

Industrial Revolution, in United States, 15

Industry: diversified, 102; specialized, 101; localized and non-localized, 105-8; see also Beef Cattle, Industrial Location factors, Manufacturing, Mining, Sheep, Silver, Steel, Sugar Beet Industry

Inside $U . S . A$. (John Gunther), 11, 262

Insurance, drain on regional funds, 162-3

Interstate Commerce Commission, $169, \quad 171-3,258,295$; see also Freight Rates

Interstate Compact, 246, 255

Iowa, manufacturing income, 131

Irrigation, 4, 17; crop land increase, $3^{0-1}$; productivity of irrigated land, 32 ; hydroelectric programs, 36 ; forest watersheds, 48; see also Agriculture, Hydroelectric power, Rainfall, Water

Izaak Walton League, 286

Jackson, Andrew, 16, 230

Japanese-American: cultural group, 54 , economic problems, 86

Jeffers, William, 257

Jefferson, Thomas, 16, 231

Joint Livestock Committee on Public Lands, 205-6; see also Beef Cattle, Sheep

Jones, J. M., 209-10

Kemp, Frank A., 224, 233

Knous, W. Lee, 257, $25^{8}, 260$

Krug, Julius, Secretary of the Interior, $27,35,200$
Labor, 17; seasonal, migratory, 84-5; wage rates, 109 ; skills, 109; in sugar beets, 220, 225

Labor force: size of, 94; changes in, 93-6; effects of war, 95

Lankford, J. D., 27

Las Vegas, Nevada, 138

Laws, Regulations and Tax Structure: tax exemptions, 117; severance tax, 117, 159; inducements to investment, 117

Lead, 12, 50; reserves of, 6o; exports of, 157

Liberal Revolts, 16, 17, 230-1

Liberalism, Western, see Western Liberalism

Lilienthal, David: industry and atomic energy, 67

Lincoln, Abraham, 16, 230

Literature, Regional, see Regional Literature

Livestock Industry: importance of, effects of, 47; Joint Livestock Committee on Public Lands, 205; see also Beef Cattle, Sheep

Livestock Lobby, 205-1 1

Living Conditions and Climate, effect on labor force and labor costs, 116

Lobbies: beef cattle, wool, 48, 193 , 202-3; silver, 193, 195-200; sugar, 193, 224-5; livestock, 205-6; electric power, 234; see also Special-Interests blocs

Location factors, industrial, see Industrial location factors

Locus of Power: East vs. West, 281; role of federal government, 282 ; conservatives vs. liberals, 282-3; concentration of power, 281-3; methods of maintaining democratic control, 283; role of state government, 284; the regional authority, decentralization, 284-6; see also Western Liberalism

Machlup, Fritz, 188

Malta plan (1930), Montana; Milk River Valley, 277; adopted by federal government, 277

Manufacturing: regional deficiency, 100; concentration of, 101; effect on income of Mountain West, 129; productivity, 149-51; see also Industry

Markets and Distribution facilities: wool scouring; woolen textiles, 115 ; phosphates, 114; Kennecott Copper Company, 115

Materials-oriented industry, 107-9 
McCarran, Pat, 196, 247, 250

Mead, Elwood, 288-9

Meat, 12; buffalo, 56; rationing and control of, $205^{-6}$

Mezerik, A. G., 261

Migration: from East to West, 87 ; increase and decline in Mountain West, 88-9o; effect of industrialization, 91 ; see also Westward Movement, Labor

Milk River Valley, see Malta Plan

Minerals: reserves idle, 3 ; reserves of in Mountain West, 34, 6o; mineral energy, 35; exports of, 157-9; need for conservation, 200; see also $\mathrm{Re}$ sources

Mining, 10; significance of, $5^{\circ}$; political influence, 53; contribution to regional income, 54; Butte, Montana, 75; Ely, Nevada, 75; and occupational patterns, 144-5; basis for liberal policy in, 294

Mineral energy, role in industrial society, $34-5$

Minerals subsidy bills, 200

Minnesota, 19

Minorities, economic problems, 79-86

Mispah-Pumpkin Creek Cooperative (1928): grazing, 277; aims of, 274; results, 274; Taylor Grazing Act (1934), 274; see also Montana

Missouri Basin Inter-agency Committee, $255^{-6}$

Missouri Valley Authority: proposed, 251; support for, $25^{6}$

Molybdenum, 5o; reserves of, 6o; exports of, 157

Montana: Mountain West, 11; productivity of irrigated land in, 33; Butte, population concentration, 75; deviation from United States industrial pattern, 103; income from manufacturing, 131, from agriculture, 130 , from trade and services, 132, from government, 135; per capita income, 137; Colorado River Compact, 248; population losses, 251; Montana Study, 262; agricultural programs, $276-7$

Montana Agricultural Experiment Station, 33

"Montana Study," 262

Mormon Church: cultural influence in Mountain West, 54; established society, 273

Mountain States Beet Growers Marketing Association, see Sugar Act Murray, James E., 251
National Forest Board of Review, see Forest Service

National Forests and Parks: Rocky Mountain National Park, 63; Yellowstone National Park, 63; Roosevelt National Forest, 211-2, 216; San Isabel National Forest, 207; Tonto National Forest, 207; Harrison, 276; Cleveland, 276; McKinley, 276; Theodore Roosevelt, 275; Conservation, 276

National Planning Association, see Committee for the South

National Reclamation Association, 235

National Woolgrowers Association, 205

Nevada: Mountain West, 11; Basic Magnesium Incorporated, 25; deviation from United States industrial pattern, 103; per capita fuel consumption, $112 \mathrm{n}$; low taxes, 117 ; income from manufacturing, 131, from agriculture, 130, from trade and services, 132, from government, 135; per capita income, 137-8

New England, 127

New Mexico: Mountain West, 11; Carlsbad, 75; deviation from United States industrial pattern, 103; Albuquerque, 104; income from manufacturing, 131, from agriculture, 132 , from trade and services, 132, from government, 135 ; per capita income, 137; Dennis Chavez, 26o; University of, 262; banks, 295

New York: manufacturing income, 131; trade and services income, 132

North Dakota, 11

Oak Ridge, Tennessee, and power reserves, 272

Occupational patterns: and per capita income, 141-2; of Mountain West, 132-3; primary, 142-6; secondary, 142-6; tertiary, 142-6; related to per capita income, $145^{-6}$

Ogden, Utah, 104

Oil Shale, see Shale Oil

Oklahoma, post-war expansion, 119

Olson, Ann, Miss, 186; see also Capehart Committee

O'Mahoney, Joseph C., 206, 253, 297n

Oregon: Westward Movement, 3; Far West, 10, 19

Pacific Coast, region, 3, 10, 19, 23

Patton, James, 241 
Paxson, Frederick L., 16

Petroleum: supplies decreasing, 3; production, 12; reserves decreasing; shale-oil, 26, 27; reserves, 35 , 6o; effects of geological forces, $5^{\circ}$

Phoenix, Arizona: industry, 104; industrial power cost high, 11 $\mathrm{n}$

Phosphates: supplies decreasing, 3; reserves of, 34, 6o; effects of geological forces, 50; production of, 114; development of, 268 ; utilization of, 294

Pick-Sloan Plan: for the Missouri Valley, 252; a hasty compromise, 252; Hoover Commission Report, 252; see also Missouri Valley Authority

Pinchot, Gifford, 55, 274-5

Pioneers, see Westward Movement

Politics, Western, see Western Politics

Population: center of, 8; increase of, 12, 19-20; rate of growth, 19-22; cultural aspects of, 53-4; density of, 72; location characteristics of, 735 ; median age, 76 ; sex ratio, 77 ; native white, 78 ; minority groups, 78 ; Indian, 80-1; Spanish-American, 83-6; immigration to West, 88-92; see also Income, Indian, JapaneseAmerican, Minorities, and SpanishAmerican

Potash, reserves of, 34, 6o

Power, concentration of, see Locus of power

Price discrimination: against consumers, 183,187 ; beneficiaries of regional, 183

Pre-emption Act (1841), Government Land policy, 13

Productivity: agriculture, 147-8; manufacturing, 150-1; mechanization of agriculture, 148; irrigation, 148-9; relation to low per capita income, 152

Railroads: influence of, "building ahead of the traffic," 14; American industrial revolution, 15; government investment in, 15; discriminatory freight rates, 170-7; defense of present rates, 170, 178-9; see also Transportation, and Freight Rates

Rainfall, 10, 42; effect on agriculture, 65; see also Climate, Hydroelectric Power, Irrigation, and Water

Rawlins, Wyoming, 204, 208

Reconversion: Geneva Steel Plant, 24; Rocky Mountain Arsenal, 24; Salt Lake City, 24; Pueblo, 24; Basic
Reconversion (continued)

Magnesium Incorporated, 25; Far West, 25; Mountain West, 24; see also World War II

Record Stockman, 208

Recreation, 10, 48; a primary use of forests, 61; national parks, 63; Carlsbad, 75; Tucson, 75; Reno, 138; Las Vegas, 138; Roosevelt $\mathrm{Na-}$ tional Forest, 216

Regional Literature, 261

Regional programs: Tennessee Valley Authority; Pacific Northwest, x; Colorado River Compact, 246; Missouri Valley Authority, 251; “Montana Study," 262; for the Mountain West, 268; type needed in Mountain West, 284

Regionalism, ix, 217, 295-6; interstate compacts, 248-9; valley authorities, 251,256 ; literature, 261; in universities, 262

Reno, Nevada, 75, 198

Resources utilization: unified approach, 274, 275; vs. resource exploitation, 277

Rifle, Colorado, 27

Roosevelt, Theodore, 57, 275-6

Rio Grande Conservancy District, 83

Rio Grande River, population concentration, 73

Rockefeller Foundation, 262

Rocky Mountain Arsenal, reconverted, 24

Rocky Mountain National Park, 63

Rocky Mountain Wool Council, $25^{8}$

Salt Lake City, Utah, 104

San Isabel National Forest, 207

Secretary of the Interior: Julius Krug, 27. 35; opposed minerals subsidies, 200

Sectionalism, ix, 198, 246, $25^{\circ}$

Severance tax, 159

Shale Oil, 26, 27; by-products, 35; reserves of, 6o; pilot plant, 61; capital investment in, 61, 268

Shinn, Charles Howard, 287-8, 289

Silver, 5 ; free coinage, 17 ; reserves of, 6o; Silver Purchase Act (1934), 194; purchase price, 195; monetary functions, 198; economists' views, 199; and conservation, 201

Sites, as factor in plant location, 111

Smith, Adam, 215

Smith, Thomas R., 89

Snake River: atomic energy, 67; population concentration, 73

Social forms of the West: cooperative 
Social forms of the West (continued) and collectivist, 287; ad hoc "law," 287; mining camps, 287; agrarian society, 288; technological society, 290; frontier outlook and influence, 291; see also Western Liberalism, Locus of power

Soule, John Babsone Lane, 9

South Platte River, population concentration, 73

Southern Governors' Conference, 257 Spanish-American: culture in Mountain West, 54; Spanish-Americans. 79; poverty of, 83 ; agriculture, 83 ; migratory labor, $84-5$; second-class citizen, 86

Special-Interest Blocs, ix; influence of, 4 ; silver, 194; wool (sheep), 202; cattle, 205; sugar-beet, 224; functional basis, 233; control of West. 234-5; effects on region, 236; see also Lobbies

Stannard, E. T., 115

Steel: Geneva Steel Plant, 24; Fontana, 25; capital investment per worker, 151; price discrimination. 182

Stimson, Henry L., 202-3

Stong, Benton J., 208

Sugar Act of 1948, 224-5

Sugar Beet Industry, see Beet Sugar Industry

Sugar bloc, activities of, 224-5

Switzerland, compared with Mountain West, 37-8

Task Force on Natural Resources, see Hoover Commission

Taussig, Frank W., 227

Tax structure, see Laws, Regulations, and Tax Structure

Taylor Grazing Act (1934), origin of. 274

Teller, Henry W., 196

Tennessee, phosphate rock deposits, 114

terms of trade, 155

Teton County, Montana, see Unified County program

Texas, 11, 19, 23; post-war expansion, 119 ; see also Gulf Southwest

Tonto National Forest, Arizona, 207

Topography: of Mountain West, 10; boundaries of Mountain West, 10; Mountain West and Switzerland, 37; effects on economy of Mountain West, 44; see also Climate, Water Resources

Transportation: Railroads, 10, 14; ef-
Transportation (continued) fects on economy, 44; see also, Railroads, Transportation facilities

Transportation facilities, 113; rates. 113; Denver meat packing industry, 114

Truman, Harry, 200, 203, 249

Tucson, Arizona: recreation center, 75 ; water shortage, 116

Tungsten, 5o; reserves of, 6o; exports of, 157

Turner, Frederick Jackson, 16, 19, 289

T. V. A. (Tennessee Valley Authority): a regional program, $x$; hydroelectric power, 36 ; and $M$. V. A. 251 ; integrated development of resources, 274 ; success of, 285

Twentieth Century Fund, 29, 270

Unified County program (1922): Teton County, Montana, 276; agricultural, 276; aims of, 277; see also Montana

Universities, Regional, 262

Uranium, reserves of, 60

Utah: Mountain West, 11; Geneva Steel Plant, 24; Salt Lake City, 24; shale-oil, 27; population concentration, 73; deviation from United States industrial pattern, 102; manufacturing nucleus, Ogden, Salt Lake, Provo, 103; per capita fuel consumption, 112; Kennecott Copper Company, 115; income from manufacturing, 131, from agriculture, 19o, from trade and services, 132, from government, 135; per capita income, 137; Colorado River Compact, 248; University of, 262; banks, 295

Vanadium, reserves of, 60

Vernal, Utah, 248, 259

Victor Chemical works, 114

Vivian, Governor, 257

Warne, Commissioner of Reclamation, 256

Wasatch Mountains, 56

Washington: Far West, 10; reconversion, 25

Washington, George, 16

Water Resources: maximum development slow, 4 ; struggle over, 28,246 , 247 , 250; utilization of, 66 ; a limiting factor in industry, $115-6$; property rights in, 245; key to western development, 296; see also Irrigation, Hydroelectric power, Rainfall 
Watts, Lyle, Chief of Forest Service, 213

West vs. East, see Western Liberalism

Western Liberalism, 6, 231-2; new issues for, 237-8; 240; national support for, 240; agricultural, 241; labor, 241-2; consumers, 242; in Missouri Valley, 256; and conservation, 273-6; and concentration of political power, 283 ; individual liberty, 283; economic policy, 292-3

Western Politics: alliance betwcen South and West, 257; regional political action, 259-61; see also Regionalism

Westward Movement: Oregon and California, 3; Mountain West, 3; influence of, 3 ; advance of, 8, 9, 19 , 2o; see also Frontier, Migration

Wheat, 12, 280

Wire Specialties and Manufacturing Corporation, 186
Wool: tariffs, 201-9; domestic industry, 203-4

Wool Scouring Industry, 115, 204

Woolgrowers Association, National, 205

World War II: contribution of Mountain West to, 23; of Far West, 23; effects of, 24; see also Reconversion

Wyoming: Mountain West, 11; shaleoil, 27; deviation from United States industrial pattern, 103; per capita fuel consumption, $112 \mathrm{n}$; income from agriculture, 130, from trade and services, 130, from manufacturing, 131, from government, 135; per capita income, 137; wool sorting at Rawlins, 204; Colorado River Compact, 248; University of, 203, 262

Yellowstone National Park, 63

Zinc, 12, reserves of, 60 , exports of, 157 
A Note On the Type Used In This Book

This book was set on the Linotype in a type-face called "Baskerville." The punches for this face were cut under the supervision of George W. Jones, the eminent English printer and the designer of Granjon and Estienne. Linotype Baskerville is a facsimile cutting from type cast from the original matrices of a face designed by John Baskerville, a writing-master of Birmingham, for his own private press. The original face was the forerunner of the "modern" group of type faces, known today as Scotch, Bodoni, etc. After his death in 1775, Baskerville's punches and matrices were sold in France and were used to produce the sumptuous Kehl edition of Voltaire's works.

This book was composed, printed and bound by Kingsport Press, Inc., Kingsport, Tennessee. Designed by Harry Ford.

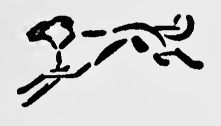


. 



\section{Morris E. Garnsey}

Morris E. GarnsEY was born in Aurora, Missouri, in 1906. He was educated at Drury College (A.B., 1928), Clark University (M.A., 1929), and Harvard (Ph.D., 1937), and also attended the Universities of Paris (1929-30) and Louvain, Belgium (1933-4).

Dr. Garnsey started his teaching as an instructor in economics at Brown, later taught at Harvard, and since 1937 has been a professor of economics at the University of Colorado in Boulder. During the war Garnsey was economic adviser to the Consumer Division of the National Defense Advisory Council; consultant to the National Resources Planning Board; and the economic analyst in the Wage Stabilization Division of the War Labor Board. His articles have appeared in Harper's, the Nation, the American Economic Review, and the Quarterly Journal of Economics, and he wrote a chapter in Saving American Capitalism, edited by Seymour E. Harris. For relaxation Dr. Garnsey likes to listen to classical music and read detective stories. 

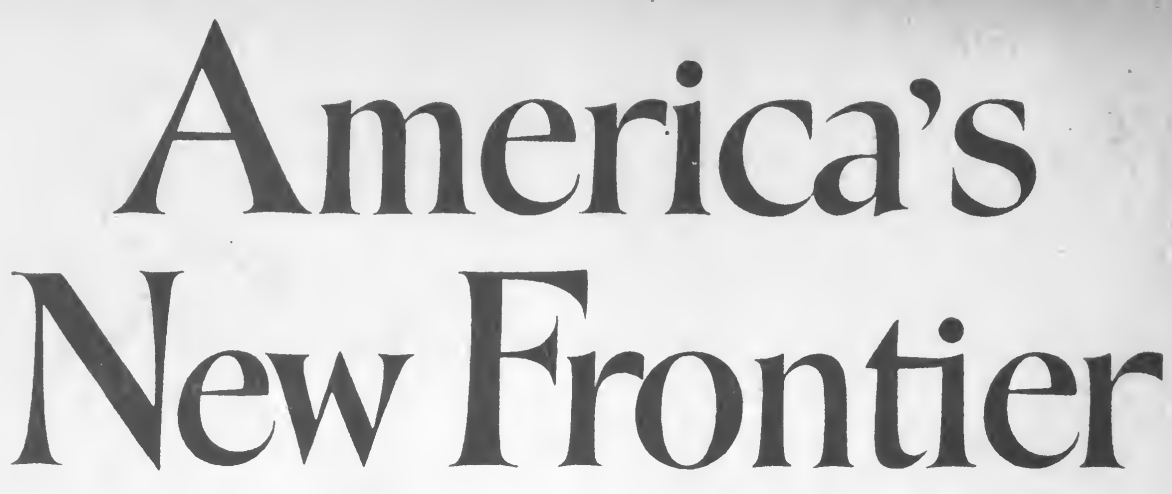

\section{From the preface}

The Mountain West has reached a significant point in its economic development-the crest of a divide. Since the first settlement the progress of the region has been upward-first rapidly and then more slowly. Now it appears that relative stability or decline lies ahead unless the West deliberately sets out to create new policies and programs for future growth. This book examines the economy of the West in some detail and attempts to discover the nature of the alternatives that the region faces in the second half of the present century. In the next three chapters the history of the rise and decline of the West is sketched briefly, and the place of the Mountain West in the American economy is described. Parts II and III contain an analysis of the resources of the region and the organization of its economic activities. The role of the Mountain West in the economic and political life of the nation is discussed in some detail in Parts IV and $\mathrm{V}$.

In Part VI a final statement of the major thesis of the book is presented. The Mountain West is seen as a new frontier for America. The possibilities of future stagnation of the region seem great; but, on the other hand, so do the opportunities for development. The divide upon which we stand today need not be the last divide if we firmly seize the opportunities that are before us. And should the major economic expansion that potentially exists in the Mountain West take place and should it be facilitated by new attitudes in government and politics, then we can truly say that in the decades ahead the West will again become a new frontier in American life-an economic frontier, a conservation frontier, and a frontier in political liberalism.

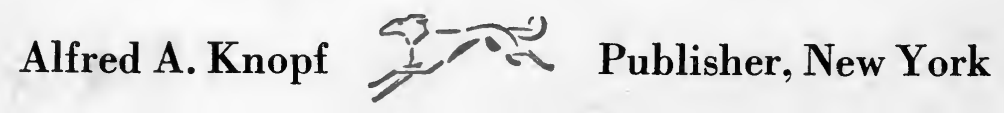

